PHOTOGRAPHIC VIEWS TAKEN IN EGYPT AND NUBIA BY JAMES DOUGLAS, M.D. AND JAMES DOUGLAS JR.

\author{
by \\ Jennifer Graham \\ Bachelor of Arts, English and Art History \\ University of Guelph \\ Guelph, Ontario, Canada 2012
}

A thesis presented to Ryerson University and George Eastman House: International Museum of Photography and Film

in partial fulfillment of the requirements for the degree of Master of Arts in the program of Photographic Preservation and Collections Management

Toronto, Ontario, Canada

(C) Jennifer Graham 2014 


\section{AUTHOR'S DECLARATION FOR ELECTRONIC SUBMISSION OF A THESIS}

I hereby declare that I am the sole author of this thesis. This is a true copy of the thesis, including any required final revisions, as accepted by my examiners.

I authorize Ryerson University to lend this thesis to other institutions or individuals for the purpose of scholarly research.

I further authorize Ryerson University to reproduce this thesis by photocopying or by other means, in total part, at the request of other institutions or individuals for the purpose of scholarly research.

I understand that my thesis may be made electronically available to the public. 


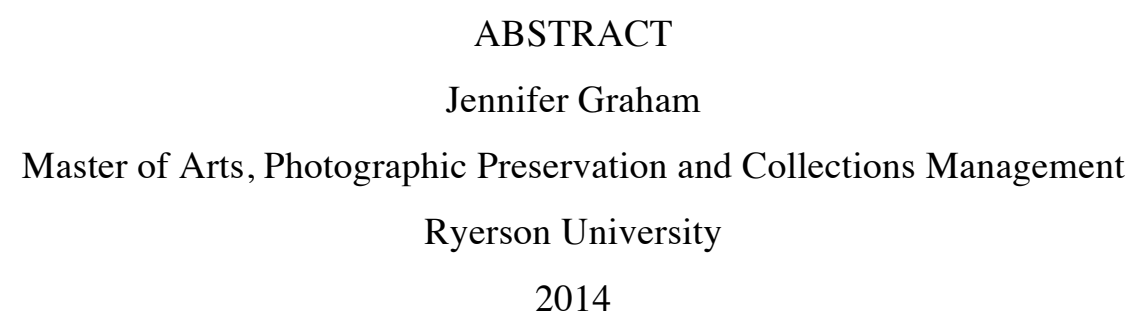

This thesis focuses on the $19^{\text {th }}$ century albums Photographic Views Taken in Egypt, which hold photographs and text by James Douglas, M.D. (1800-1886) and his son James Douglas Jr. (1837-1918). The albums are held in the collections of the Archive of Modern Conflict (AMC), Toronto, Canada, the British Library, London, England, The Brooklyn Museum's Wilbour Library of Egyptology Special Collections in Brooklyn, New York City, and Université Laval in Quebec City, Quebec, Canada. The albums are also identified as Photographic Views Taken in Nubia and Photographic Views of Egypt \& Nubia and include views of both Egypt and Nubia. Since the albums were privately printed for friends and family, little research and academic discussion has taken place on them. This thesis strives to resolve this gap in academic discussion and has begun a discourse on Photographic Views Taken in Egypt. 


\section{ACKNOWLEDGEMENTS}

I would like to thank everyone who assisted me during my research and writing of this project. I was lucky to have been helped by people who also cared for the work that I was doing, and its development is indebted to their support. Thank you to the institutions that allowed me access to their collections and to the individuals at those institutions that guided me: Jill Offenbeck and Mike Robinson at the Archive of Modern Conflict, John Falconer at the British Library, Deirdre Lawrence and Emily Atwater at the Brooklyn Museum, and Sonia Léger at Université Laval. I am also grateful to Anne E. Peterson, Steven Evans, David Harris and all of the others who took the time to speak with me about Photographic Views Taken in Egypt.

To my first reader and thesis advisor, Don Snyder, your compassion was invaluable to this project. Your enthusiasm is contagious, and I will be forever thankful for your encouragement. I would also like to thank my second reader Lori Pauli, Curator Photographs Collection at the National Gallery of Canada, whose expertise and assistance was an incredible asset to my thesis.

Thank you to my friends, who always found a way to keep me laughing. Julia, thank you for your unconditional love and patience. Patrick, thank you for always lending your ears and keen eyes when I needed them most. To my family, this would never have been possible without you. Thank you for your unfaltering love and support, and for always believing in me. 


\section{TABLE OF CONTENTS}

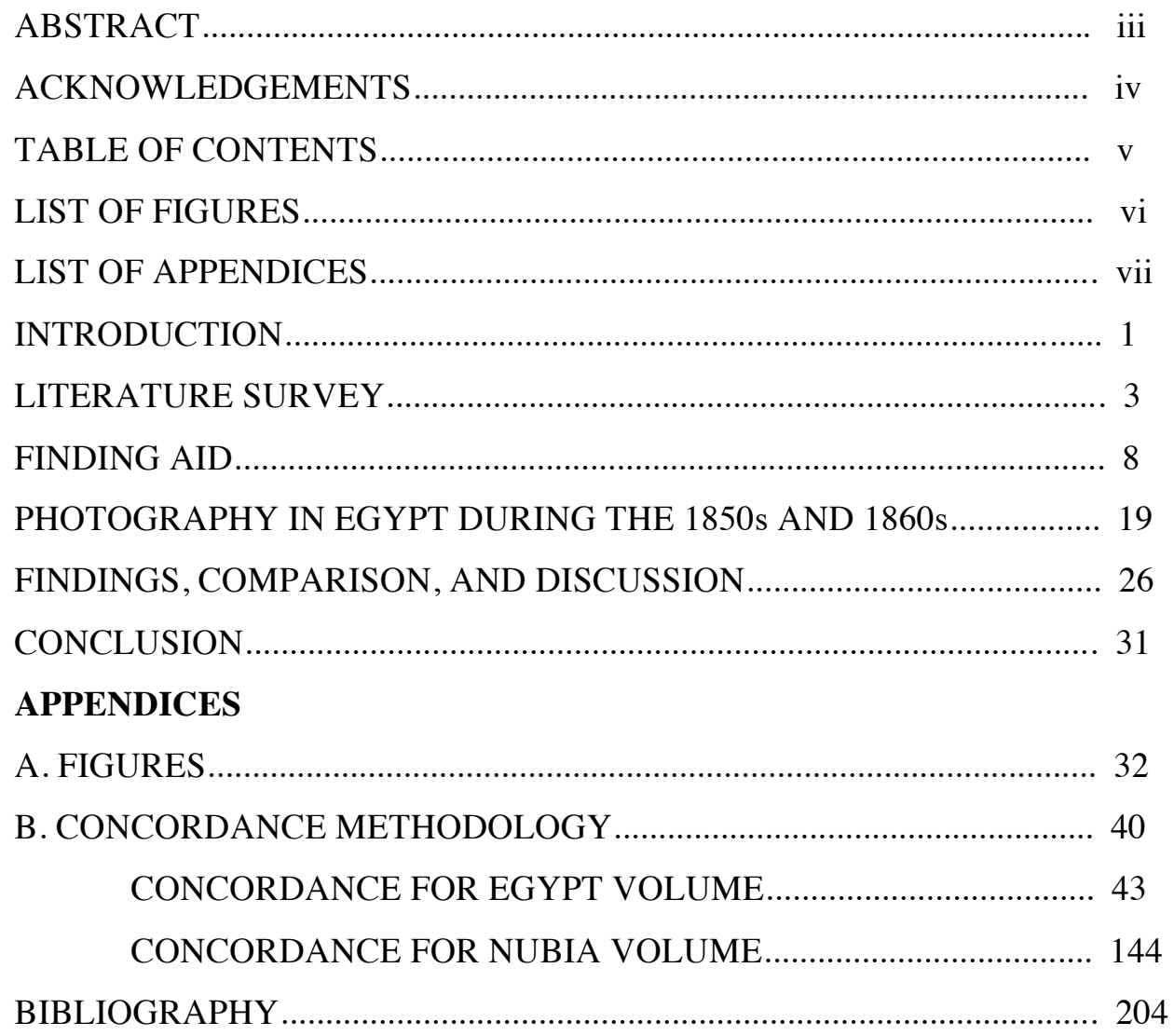




\section{LIST OF FIGURES}

Figure 1. Inscription to Dr. Landry by James Douglas, M.D. in Photographic Views in Egypt \& Nubia. Image courtesy of Université Laval.

Figure 2. Inscription to Dr. Russell by James Douglas, M.D. in Photographic Views in Egypt \& Nubia. Image courtesy of AMC.

Figure 3a. Cover of Photographic Views in Egypt \& Nubia. Image courtesy of AMC.

Figure 3b. Cover of Photographic Views in Egypt \& Nubia. Image courtesy of Université Laval.

Figure 4. Title page from Photographic Views of Egypt \& Nubia with the photograph titled "Our Nile Boat" by James Douglas, M.D. and James Douglas Jr. Image courtesy of Université Laval.

Figure 5. Title page from Photographic Views in Egypt \& Nubia with the photograph titled "Our Nile Boat" by James Douglas, M.D. and James Douglas Jr. Image Courtesy of AMC.

Figure 6. Title page from the ca. 1862 publication Lower Egypt, Thebes, and the Pyramids by Francis Frith with the photograph titled "Traveller's boat at Ibrim" taken in 1857. Image courtesy of the Toronto Public Library.

Figure 7. "Luxor- Mustapha Aga" by James Douglas, M.D. and James Douglas Jr. Image courtesy of AMC.

Figure 8. "Mummies" by James Douglas, M.D. and James Douglas Jr. Image courtesy of AMC.

Figure 9. "Crude Brick Building” by James Douglas, M.D. and James Douglas Jr. Image courtesy of AMC.

Figure 10. Detail of "Crude Brick Building” by James Douglas, M.D. and James Douglas Jr. Image courtesy of AMC.

Figure 11. "Koum Ombo- Near View" from the ca. 1862 publication Upper Egypt and Ethiopia by Francis Frith taken in ca. 1857. Image courtesy of the Toronto Public Library.

Figure 12. "Kom Ombos- Temple" by James Douglas, M.D. and James Douglas Jr. Image courtesy of AMC. 


\section{LIST OF APPENDICES}

A. Figures
B. Concordance of images and text in Photographic Views Taken in Egypt 


\section{INTRODUCTION}

Initially this thesis project focused on creating a finding aid for the three photographic albums Photographic Views Taken in Egypt (1860-1874), created by James Douglas, M.D. and his son James Douglas Jr. The albums are also identified as Photographic Views Taken in Nubia and Photographic Views of Egypt \& Nubia, but for the purpose of this project I use the title Photographic Views Taken in Egypt to refer to all of the albums. My primary research, which took place at the Archive of Modern Conflict (AMC), Toronto, determined that the Douglas family was prominent in both Canadian and American history; however, very little had been written on their photographic accomplishments. It became apparent that these three albums required much more than a finding aid to begin a discourse on their potential significance to the history of photography. My project thus became concerned with the question: how should one discuss a set of photographic albums when they have never before been discussed in the history of photography? In response to this question, my project aims to create a foundation on which the albums Photographic Views Taken in Egypt can be considered and examined in an academic context.

While conducting research, I located three other institutions that held copies of the Douglases' albums: the British Library in London, England, The Brooklyn Museum's Wilbour Library of Egyptology Special Collections in Brooklyn, New York City, and Université Laval in Quebec City, Quebec, Canada. For the purpose of my project I travelled to these public institutions to determine and record any key similarities and differences between the albums.

Firstly, my project aims to discuss the lives and work of James Douglas, M.D. and his son James Douglas Jr. and to identify the contents of the three albums at the AMC in a finding aid. Secondly, I intend to illustrate the value of Photographic Views Taken in Egypt by providing context for the Douglas albums through a comparison with similar albums created by other more well-known photographers who photographed Egypt during the 1850s and 1860s. This section titled "Photography in Egypt during the 1850s and 1860s" focuses on the work of photographers Maxime Du Camp, Félix Teynard, J.B. Greene, and Francis Frith and explores the photographic accomplishments of the aforementioned photographers to draw parallels between the Douglases' Photographic Views Taken in Egypt. Finally, in the third section titled "Findings, Comparisons and Discussion," I review my key findings to establish a comparative context in which the albums 
can be considered for future researchers. A concordance of all of the images from the Douglas albums assists in the comprehension of the albums, and illustrates the similarities and differences that exist between each of the albums in the various collections. 


\section{LITERATURE SURVEY}

A literature survey of the history of photography of Egypt, on travel in Egypt during the $19^{\text {th }}$ century, and on the Douglas family was conducted to develop a comprehensive overview of the six photographic albums that the Douglases produced. In order to provide a context for the trips that the Douglases made to Egypt and to understand their personal interests in photography, biographical and autobiographical texts were consulted, despite the fact that these texts did not directly discuss the albums themselves. As a result, this survey demonstrates the need for the Douglas albums to be researched and analyzed so that they can become integrated into the record of photographic history.

Secondary Sources:

Nissan N. Perez's text Focus East: Early Photography in the Near East 1839-1885 (1988) is a helpful resource that explores the history of photography in Egypt and lists the biographies of known photographers who photographed in the Near East. Perez notes there are only a few known examples of amateur and travel photographs documented by unknown tourists, generally made by small format cameras, which included photographs of themselves in front of sites, and provided different angles that varied from the commercial views. ${ }^{1}$ Since amateur photographers made photographs primarily for personal records, and did not print numerous copies or publish them, examples are uncommon and deductions about the role of these images have only been made from the prints that have survived. ${ }^{2}$ In a similar manner to these photographs, the Douglas albums feature images of the family in front of sites and provide assorted views of famous places in Egypt. In contrast to most other amateur albums from this period, however, the images found in the Douglas albums were not made with a small format camera. ${ }^{3}$ Perez's description of amateur photographers is better aligned with the travelers who emerged in the late 1880 s, using handheld, compact cameras such as the Kodak \#1. ${ }^{4}$ What can be concluded from Perez's text is that there is a lack of available sources of amateur travel

\footnotetext{
1 Nissan N. Perez, Focus East: Early Photography in the Near East 1839-1885 (New York:

Ibid., 87.

The photographs in the Douglas albums were made from a large format, folding camera that was stabilized with a tripod stand.

$4 \quad$ Ibid., 87.
} 
photography in Egypt prior to 1880, and that an analysis of the Douglas albums would provide further insight to photography in Egypt at that time.

Kathleen Stewart Howe's Excursions Along the Nile: The Photographic Discovery of Ancient Egypt (1993) provides an excellent summary of the history of how travel and photography began in Egypt. Although Howe does not mention the Douglases, she notes the fact that only a small number of "serious amateurs" made photographs in Egypt by 1860, since commercial practitioners dominated Egyptian photography at that time. ${ }^{5}$ As the photographs in the Douglas albums were made in the early 1860s, Howe's text confirms that the albums are examples of a rare or unconventional perspective in photography's history in Egypt.

In the introductory text to Nile Notes of a Howadji: a Bibliography of Travelers' Tales from Egypt, from the Earliest Time to 1918 (1992), Martin R. Kalfatovic traces the history of travel literature from antiquity to just after World War I. Following the introduction, the text lists travel literature from Egypt chronologically in a bibliography which is sourced predominately from the Library of Congress catalogue. Kalfatovic also uses Edward Cox's A Reference Guide to the Literature of Travel (1935-49), The Brooklyn Institute of Arts and Sciences' Catalogue of the Egyptological Library and other books from the collection of the late Charles Edwin Wilbour (1924), and the British Library catalogue as supplementary sources. Primarily, the criteria of the works discussed in this text are firsthand accounts of men and women who visited the Nile Valley and the surrounding deserts from antiquity to World War I. Kalfatovic limits the scope of the bibliography by not including works that are strictly scientific, archaeological, political, instructional, or anthropological in nature. ${ }^{6}$ Kalfatovic's book is especially relevant for the purpose of this literature survey because the Douglas albums are included in the bibliography where they are cited as being in the collection of the British Library. Kalfatovic, however, explicitly states that they were "not seen" for the publication, as he was unable to consult every listed piece of travel literature in the bibliography. ${ }^{7}$ While Kalfatovic's inclusion of the Douglas albums in his bibliography makes it clear that they are considered a part of the history of $19^{\text {th }}$ century literature on the subject of travel in Egypt, he does not acknowledge the role of photography in these albums.

\footnotetext{
$5 \quad$ Kathleen Stewart Howe, Excursions Along the Nile: The Photographic Discovery of Ancient Egypt (Santa Barbara, CA: Santa Barbara Museum of Art, 1993), 35.

6 Martin R. Kalfatovic, Nile Notes of a Howadji : a Bibliography of Travelers' Tales from Egypt, from the Earliest Time to 1918 (Metuchen, NJ: Scarecrow, 1992), xxix.

$7 \quad$ Ibid., 198.
} 
Primary Sources:

Specific guidebooks by Sir G. Wilkinson, Charles Irby, James Maugles, and Giovanni Belzoni, were surveyed because they provided information on what was available to travellers at the time the Douglases traveled. The Douglases, in the written text of the albums, cite the aforementioned authors as resources that they consulted before and possibly during their travels. The guidebooks supply information on history, culture, sites, and the geography of Egypt. Sir G. Wilkinson's A Popular Account of the Ancient Egyptians: 2, Volume 2 (1854) ${ }^{8}$ and, A handbook for travellers in Egypt: including descriptions of the course of the Nile to the second cataract, Alexandria, Cairo, the Pyramids, and Thebes, the overland transit to India, the peninsula of Mount Sinai, the Oases, $\& c .(1847)^{9}$ are directly quoted or mentioned as a reference on three occasions in the albums. Wilkinson's A Popular Account of the Ancient Egyptians discusses the inhabitants of Egypt, art, architecture and religious ceremonies. A handbook for travellers in Egypt is divided into chapters based on the cities in Egypt and sub-sectioned into the routes or excursions taken from that city. This guide provides information on the costs of travel, supplies and goods, the duration of each route, where to stay, sites and a history of Egypt and its rulers. Two other texts, one written by Charles Irby and James Maugles, the other by Giovanni Belzoni, are cited in the Douglas albums. Belzoni's publication, Narrative of the operations and recent discoveries within the pyramids, temples, tombs, and excavations, in Egypt and Nubia; and of a journey to the coast of the Red Sea, in search of the ancient Berenice, and of another to the oasis of Jupiter Ammon (1820) is an account separated into journeys, describing sites, dangers, and depicting events that took place during his travels..$^{10}$ Irby and Maugles' text Travels in Egypt and Nubia, Syria, and the Holy Land; A Journey Round the Dead Sea, and Through the Country East of the Jordan (1844) is a day by day travel log that is divided into chapters by place and documents sites and occurrences seen and experienced while they traveled. ${ }^{11}$

\footnotetext{
8 Sir John Gardner Wilkinson, A Popular Account of the Ancient Egyptians: 2, Volume 2 (London: John Murray, 1854).

$9 \quad$ Sir John Gardner Wilkinson, A Handbook for Travellers in Egypt: including descriptions of the course of the Nile to the Second Cataract, Alexandria, Cairo, the Pyramids, and Thebes, the overland transit to India, the peninsula of Mount Sinai, the Oases, \&c. (London: John Murray, 1847).

$10 \quad$ Giovanni Battista Belzoni and Sarah Belzoni, Narrative of the operations and recent discoveries within the pyramids, temples, tombs, and excavations, in Egypt and Nubia; and of a journey to the coast of the Red Sea, in search of the ancient Berenice, and of another to the oasis of Jupiter Ammon (London: John Murray, 1820).

11 Charles Leonard Irby and James Mangles, Travels in Egypt and Nubia, Syria, and the Holy Land; including a Journey round the Dead Sea, and through the Country East of the Jordan (London: John Murray, 1844).
} 
The guidebooks helped to inform how the Douglases were advised to travel, what sites were important to visit, as well as interesting tips and specific pieces of history about certain sites. It is interesting to note that although these texts provided significant information on travel in Egypt, they never mention the use of photography to document Egypt, despite three of the texts being written after the invention of photography.

Not surprisingly, it is the biographical and autobiographical literature that provides the best information on the Douglas family's travels to Egypt. This information provided a background into the father and son's travels to Egypt, offering context for their fascination and desire to record the sights that they witnessed.

In the part-biographical, part-autobiographical work Journals and Reminiscences of James Douglas M.D. (1910) published by James Douglas Jr., the reader learns that James Douglas Sr. had spent nine winters abroad between 1851 and 1865, six of which were allocated to Egypt. ${ }^{12}$ The first trip that Douglas Sr. took to Egypt was made with his son James Douglas Jr. when he was fifteen years old. ${ }^{13}$ On another excursion to Egypt in 1854-1855, the entire family including James Douglas Sr., his wife, two sons, and a cousin joined him on the trip. ${ }^{14}$ Although there is no mention of the photographic albums, there is a passing reference to some photographs when James Douglas Jr. explains that when he took a job in Pennsylvania in 1875, he and his father packed, "a carload of our old belongings from Glenalla- a few pictures... and my father's Egyptian collection [which was later donated to the Metropolitan Museum]". ${ }^{15}$ This text was integral in providing information on the Douglases' interest in Egypt as well as the importance of photographs to the family.

Under the chapter titled "Parentage" in his book, James Douglas: A Memoir (1940), H.H. Langton notes that James Douglas Jr. once recalled that during the trips taken to Egypt, his father, James Douglas Sr.: "became an enthusiastic collector of mummies and all that appertained to them." ${ }^{16}$ Langton reveals that while accompanying his father to Egypt, James Douglas Jr.'s interest in Egyptian culture developed into a specialization that he wrote and spoke on publicly.

12 Dr. James Douglas and James Douglas Jr., Journals and Reminiscences of James Douglas M.D. (New York: Private Printing, 1910), 180.

13 Ibid., 180.

$14 \quad$ Ibid., 181.

15 Ibid., 253.

16 H.H. Langton, James Douglas: A Memoir (Toronto: University of Toronto Press, 1940), 25. 
On May 15, 1862, James Douglas Jr. presented his article "The Belief of the Ancient Egyptians Respecting a Future State" to the Literary and Historical Society of Quebec, illustrating his recent experiences in Egypt. ${ }^{17}$ In a little over four decades later, on September 3, 1903, an article James Douglas Jr. published in the Nation secured his status as a reputable figure of Egyptology. As Langton observes: "after this article it inevitably followed that other books on modern Egypt should be assigned to him for review." ${ }^{18}$ Though Langton does not refer to the photographs made by James Douglas Sr. or his son specifically, a reference is made to James Douglas Jr. acting as a photographer for the Canadian party under Edward David Ashe in 1869, while they were recording their observations of a solar eclipse. This reference is the first published mention of the Douglas family's activities as photographers. ${ }^{19}$ While it is not explicitly known whether or not the photography in the Douglas albums was a collaborative effort between the son and the father, this fact supports James Douglas Jr.'s ability and involvement in the creation of the photographs.

While the biographical and autobiographical literature aided in providing greater insight into the lives of James Douglas, M.D. and James Douglas Jr. and established their presence in Egypt, the writings did very little to provide any information on the photographs published in the albums Photographic Views Taken in Egypt.

In conclusion, after conducting this survey, it was discovered that no published account exists within the history of photography in Egypt on James Douglas, M.D. or James Douglas Jr., and very little information is known of their photography from literature on travel in Egypt and their biographical and autobiographical works. Both private and public institutions including the Archive of Modern Conflict, the British Library, the Wilbour Library of Egyptology, and the Université Laval have all collected the Douglases' photographic albums, justifying the rationale to re-evaluate their absence from the narratives of photographic history. Although the albums were not made commercially available or publicly published, this should not be a reason to exclude the photographic albums from the history of photographs taken in Egypt, and should therefore be included in future writings on this aspect of the history of photography.

$17 \quad$ H.H. Langton, James Douglas: A Memoir, 109.

18 Ibid., 109.

19 Ibid., 107-8. 


\title{
FINDING AID
}

\section{Creator}

James Douglas, M.D. and James Douglas Jr. with contributing text by Naomi Douglas and Mary MacDonald.

\section{Title}

Photographic Views Taken in Egypt: by [blank] during the winter, 1860-1; Glenalla, January, 1862

\section{Other Title}

Photographic Views Taken in Nubia

Photographic Views of Egypt \& Nubia

\section{Inclusive Dates}

1860-1874

\begin{abstract}
The three photographic albums compiled by James Douglas, M.D. and James Douglas Jr. hold albumen prints and descriptive texts about sites, monuments, people, history and events that occurred during their travels in Egypt and Nubia in the winter of 1860-1861. The master sets, located at the British Library and Wilbour Library of Egyptology, hold two volumes: photographs taken in Egypt and photographs taken in Nubia. Two of the albums at the AMC, Photographic Views in Egypt \& Nubia and Photographic Views Taken in Egypt, are composed of selections from both volumes of the master set, and the third album Photographic Views Taken in Nubia is a full version of the second volume of the master set. In total as a collective, the albums hold 106 albumen prints.
\end{abstract}

\section{Location}

Archive of Modern Conflict (AMC), Toronto, ON, Canada 


\section{AMC Accession number}

Box 1: Photographic Views in Egypt and Nubia: 14481

Box 2: Photographic Views Taken in Nubia: 20253_1

Box 3: Photographic Views Taken in Egypt: 20253_2

\section{Size}

Photographic Views in Egypt and Nubia: $42 \mathrm{~cm}(\mathrm{~h}), 33 \mathrm{~cm}(w), 3.5 \mathrm{~cm}(\mathrm{~d})$

Photographic Views Taken in Nubia: $43 \mathrm{~cm}(\mathrm{~h}), 35.5 \mathrm{~cm}(\mathrm{w}), 4 \mathrm{~cm}(\mathrm{~d})$

Photographic Views Taken in Egypt: $42 \mathrm{~cm}(\mathrm{~h}), 37 \mathrm{~cm}(\mathrm{w}), 4.5 \mathrm{~cm}(\mathrm{~d})$

\section{Biographical Note}

James Douglas, M.D. or James Douglas Sr., was born on 20 May 1800 in Brechin, Scotland and was the son of a Methodist minister, George Douglas and his wife, Mary (Mellis) Douglas. His son James Douglas Jr. was born on 4 November 1837 in Quebec, Canada.

James Douglas, Sr. attended Edinburgh University to study surgery in 1818 and received his diploma as a surgeon from the Royal College of Surgeons in Edinburgh in May 1820. He then proceeded to London, England and passed the examinations of the Royal College of Surgeons in London in April 1820. From an early age, Douglas Sr. was a keen traveller, and worked as a surgeon in the spring and summer of 1819 on a whaling ship bound for a Greenland fishery. Afterwards he spent a year in India as a surgeon, returned from his travels in 1822 and then in 1823 worked as the Director of Medical services of the Poyais settlement on the Mosquito Coast in Honduras. While on the Mosquito Coast Douglas Sr. became seriously ill, with what was probably yellow fever, and was transported to Boston, Massachusetts, U.S.A to receive medical treatment. Following his recovery, he was persuaded to extend his trip to North America instead of finding passage back to England. He made his way to Utica, NY, intending to see Quebec where his two former colleagues, John Stephenson and Andrew Fernando Holmes, resided. However, repair work being done at the time on the Erie Canal prevented Douglas Sr. visiting Quebec. While staying in Utica, he saved the life of a farmer who had accidentally impaled himself with a pitchfork. This act propelled him into the status of a local celebrity. James Douglas Sr. then met and married Hannah Williams, built a house and settled down to practice medicine in Utica. He delivered lectures at Auburn Medical College and had a dissecting room over his office 
where he dissected cadavers to learn more about anatomy. This practice was considered illegal and after being caught and receiving a warning from a judge in Utica, Douglas Sr. would continue this practice in secret. When a cadaver was recognized as a well-known figure from the city, James Douglas Sr. was forced to flee to Canada in fear of more severe legal consequences in the winter of 1825-1826. Douglas Sr. and his wife travelled to Quebec and decided to settle there on 13 March 1826. There, he started a practice gaining notice for his surgical ability in the areas of strabismus and clubfoot. In the winter of 1828-1829 he suffered from typhus fever and in 1830 lost his wife to tuberculosis. A year later James Douglas Sr. married Elizabeth Ferguson. They had four sons, two who died in infancy, James Douglas Jr., and another son named George who died in 1861 .

In 1837, the same year that James Douglas Jr. was born, James Douglas, Sr. worked as the doctor in charge at the naval hospital, which became the Marine and Emigrant Hospital. In 1845 he accepted the responsibility for the insane in Quebec, a position that was offered to him by the governor Sir Charles Theophilus Metcalfe. In partnership with doctors Joseph Morrin and Charles-Jacques Frémont, James Douglas Sr. purchased a house in Beauport, Quebec and had it converted into an asylum for patients considered mentally insane. This residence was called Glenalla. In the summer of 1850 Douglas Sr. developed bronchitis and prescribed himself winters abroad, traveling to Europe, Egypt and Palestine. Deciding to retire from private practice and to only work at Glenalla during the summer months, Douglas Sr. spent the winter months in warmer climates to avoid the cold weather in Quebec. Between 1851 and 1865 he traveled abroad 9 times, with six of his visits devoted to Egypt. Douglas Sr. collected mummies and Egyptian antiquities that would later be loaned by his son James to the Metropolitan Museum in New York. After the deaths of Dr. Morrin and Dr. Frémont, Dr. Jean-Étienne Landry became co-owner of the asylum at Beauport with James Douglas Sr. In 1865, Douglas Sr. had his share in the asylum liquidated. His financial standing was further diminished as a result of poor investments made in mining speculations. In 1875 he moved with his son James to Phoenixville, Pennsylvania, where he died of a stroke in 1886. He was buried in Quebec.

Douglas Sr.'s son, James Douglas Jr. graduated from Queen's University in Kingston, Ontario, Canada in 1858 and continued his studies at the University of Edinburgh, Scotland. He studied theology with the intention of becoming a minister and was formally admitted to the ministry of the Church of Scotland as a licentiate in 1861. By 1864 James Douglas Jr. had renounced his decision to become a minister and began studying medicine at Université Laval for 
two years with the idea of following in his father's footsteps and looking after the asylum. Instead he became interested in chemical research through his friendship with Thomas Sterry Hunt, a Professor of Chemistry at Université Laval from 1856 to 1862. Through this friendship with Sterry, James Douglas Jr. conducted experiments of the chemical reduction of mineral ores, especially those with gold and copper content. In 1864 he became managing director of the Harvey Hill Copper Co. in Quebec and in 1875 he moved to the United States to look after the copper works in Phoenixville, PA.

The first trip that James Douglas Jr. made to Egypt and Europe was in 1852 with his father. In 1854 the entire family embarked to Egypt, Palestine and Europe. On this trip, they were included in the first group of Christians to enter the sacred enclosure at Jerusalem where the Mosque of Omar stands. On their return home in May 1855, James Douglas Jr. and his mother remained in Paris to view the Exposition Universelle des produits de l'Agriculture, de l'Industrie et des Beaux-Arts de Paris.

In the autumn of 1860 James Douglas Jr. married Naomi Douglas (of no relation) from Scotland and their honeymoon was spent on a journey up the Nile with James Douglas, Sr. in the winter of $1860-1 .^{20}$ This trip resulted in the creation of the photographs found in the albums of Egypt and Nubia.

James Douglas Jr. was a member of the Literary and Historical Society of Quebec, acting as Librarian from 1863-4, 1867-8, and 1871-1874, Vice-President from 1865-6, and President from 1875-1876. His first contribution to the Society's publication Transactions was read in May 1862 titled, "Belief of the Ancient Egyptians Respecting a Future State." ${ }^{21}$ In it he describes the west sculptured wall of a side chamber in the Temple of Deir el-Medina at Thebes, found in the photograph "Judgment Scene" from the Egypt volume in the photographic albums he and his father created. In February 1865, James Douglas Jr. discussed Egypt again with the article published in Transactions titled, "On Two Mummies from Thebes," in reference to the mummies brought back by James Douglas, M.D. and exhibited to the Society in November $1864 .^{22}$ James Douglas Jr. also discusses working as a photographer for the Canadian Eclipse Party under

20 Elizabeth, James Douglas, M.D.'s wife and James Douglas Jr.'s mother, died in 1859.

21 Douglas Jr., James, "The Belief of the Ancient Egyptians Respecting a Future State." (Quebec: Hunter, Rose \& Co.), 1865.

22 Douglas Jr., James, “On Two Mummies from Thebes, in Upper Egypt.” (Quebec: Hunter, Rose \& Co.), 1864 . 
Commander E. D. Ashe in 1869 in the essay "On Recent Spectroscopic Observations of the Sun, and the Total Eclipse of the $7^{\text {th }}$ August 1869 " which he read to the Literary and Historical Society of Quebec in 1870. After moving to the United States from Canada in 1875, James Douglas Jr. remained supportive of the Society and was elected Honorary President in 1900 until his death.

James Douglas Jr.'s decision to work and live in the United States would help to drive his career forward in a perhaps unexpected manner. In 1881, Douglas Jr. was approached by Phelps, Dodge \& Co. to evaluate prospective copper mines in southeastern Arizona. His enthusiasm and expertise would prove to be very influential and impactful for Phelps, Dodge, \& Co. as his input led to the successful development of mines such as the Atlanta Claim and the Copper Queen Mine. Douglas Jr. would continue to be a pioneer in the growth of mining, smelting, and, eventually, railroad development in southern Arizona and some regions in northern Mexico. An important result of his ongoing involvement would be the honorable naming of Douglas, Arizona in 1905, a small smelter town that Phelps, Dodge \& Co. developed for their own mines.

In 1899, Douglas Jr. received an honorary degree of LL.D from McGill University, Montreal, Quebec, Canada. In June 1918 Douglas passed away, leaving behind four children, Elizabeth, Walter, James and Edith. The Douglas Library at Queen's University, which was completed in 1924, was named in his honour.

Sources:

Douglas, James, and James Douglas. Journals and Reminiscences of James Douglas, M.D. New York: Private Printing, 1910.

“Douglas, James, 1837-1918. Dr. James Douglas Collection, 1863-1935.” Arizona Historical Society. Web May 15, 2014.<http://www.azarchives online.org/xtf/view? docId=ead/ahssd/ms1031.xml>.

Douglas Jr., James, "The Belief of the Ancient Egyptians Respecting a Future State." Transactions, Volumes 4-5: Literary and Historical Society of Quebec. Quebec: Hunter, Rose \& Co., 1865.

Douglas Jr, James, “On Two Mummies from Thebes, in Upper Egypt.” Transactions, Volumes 25: Literary and Historical Society of Quebec. Quebec: Hunter, Rose \& Co., 1864.

Douglas Jr., James, "On Recent Spectroscopic Observations of the Sun, and the Total Eclipse of the $7^{\text {th }}$ August 1869." Transactions, Volume 3: Literary and Historical Society of Quebec. Quebec: Hunter, Rose \& Co., 1870.

Langton, H. H. James Douglas: A Memoir. Toronto: University of Toronto, 1940. 
Leblond, Sylvio. "Douglas, James (1800-86)." Dictionary of Canadian Biography. University of Toronto, 1982. Web. 27 Sept. 2013. <http://www.biographi.ca/en/bio/ douglas_james_1800_86_11E.html>.

\section{Scope and Content}

It is important to note that the Archive of Modern Conflict (AMC), Toronto, the British Library, England, The Brooklyn Museum's Wilbour Library of Egyptology Special Collections in Brooklyn, New York City and Université Laval, Quebec City, Quebec, Canada do not all hold the same versions of the Douglas albums. There are two types of albums, those that follow a 'master set' and those that are composed of a selection from the master set. The collections of the British Library and the Wilbour Library of Egyptology hold albums that can be considered a master set. The master set is comprised of 49 images of Egypt, including a photograph on the title page, corresponding letterpress text, and a table of contents in the first volume. The second volume is intended to hold 35 images of Nubia, including a photograph on the title page, corresponding text, and a table of contents. However, the final image titled "Abou Simbel- Rameses Slaying His Enemies" in the second volume of the consulted versions of the albums is not present. In two albums, one at British Library and the other in Photographic Views Taken in Nubia at the AMC, there is a pencil inscription in the place of the intended photograph stating that the image is missing or that it will be added at a later date when the album is finished. It is uncertain whether or not any other albums in existence hold this image.

The three albums of Photographic Views Taken in Egypt at the AMC are large bound publications. The three albums are distinctly different in their appearance; however, each album holds leaves of plates and corresponding letterpress text.

The album Photographic Views in Egypt \& Nubia (14481) is made with an unidentified type of red treated cloth with burgundy leather detail on the spine, corners and in the center on the cover where the title is embossed in gold lettering. The title "PHOTOGRAPHIC VIEWS / IN / EGYPT \& NUBIA.” is surrounded by decorative gold embossed lines and detailing. The spine and corners also display gold embossed decorative detail that lines the interior edges of the burgundy leather to transition into the lighter red cloth. The album holds 39 albumen photographs, including the photograph on the title page, and is made from a selection of images 
from both volumes of the master set. There is a handwritten inscription in ink that is located before the title page by James Douglas, M.D. in the album that reads ${ }^{23}$ :

“Glenalla, December $25^{\text {th }} 1874$ /

My Dear Sir, /

Since you entered the profession as my Pupil / now nearly forty years ago, our intercourse has inva- / riably been of a kind which has left none but pleasant / memories behind it. /

I watched with great interest your progress as a / medical student, and your well earned [successes?] / in your subsequent professional career. /

I can testify to your intimate knowledge of anatomy / and surgery, of which you gave me ample proof in my own / person, during some months of the past year, while I suffered / from the effects of a comminuted fracture of the bones of the / leg.

To you, and to Dr. Landry I was indebted for the alleviation of much personal suffering, - for the preservation / of my limb, - and for the ability to again walk about. /

Professional usage prohibits the offer of a fee for your / great trouble and loss of valuable time, on that occasion, / it does not however prevent my offering to you a few of / the photographic views and descriptions of scenes and / occurrences on the banks of old father Nile. They were / taken and described by my son and me, and may serve / to occasionally remind you of / James Douglas. / Dr. Russell."

The album Photographic Views Taken in Nubia (20253_1) has a red leather binding. The cover and back are both highly decorated in gold embossed detailing that borders the title "PHOTOGRAPHIC / VIEWS / TAKEN IN / NUBIA". The edges of the pages in the album are gilded and the album holds 34 albumen photographs.

Photographic Views Taken in Egypt (20253_2) is a green cloth album with burgundy leather corners and spine. Similar to Photographic Views in Egypt \& Nubia, there is embossed gold decorative detailing that lines the interior edges of the burgundy leather corners and spine. The album holds 33 albumen photographs, including the photograph on the title page, and is composed of photographs from a selection of the first and second volumes of the master set. The album is inscribed to the Cairns family, relatives of Naomi Douglas, James Douglas Jr.'s wife. The inscription reads:

\footnotetext{
${ }^{23}$ The inscription is dedicated to a man named Dr. Russell who worked alongside Dr. Landry to save James Douglas, M.D.'s broken leg.
} 
"Presented to Mrs and Miss [?] Cairns / By M.Douglas./

Glenalla, October 15. 1862.”

The British Library album was presented and donated to the British Museum by James Douglas Jr. in 1908. The album was originally one album, but after conservation work was completed the album was separated into two albums each holding a different volume: the volume of views of Egypt and the volume of views of Nubia. This master set includes one image on each title page for the different volumes. The first volume's title page displays a photograph of James Douglas Jr., James Douglas, M.D., Naomi Douglas and a young unidentified boy with Egyptian art and antiquities. The second volume's title page photograph is of James Douglas Jr., James Douglas, M.D., and Naomi Douglas seated at a table. Due to the high reproduction and publishing costs of the albums at the British Library, there are no images from this institution.

The Brooklyn Museum's Wilbour Library of Egyptology Special Collections also holds a master set; however, the title pages do not have photographs like the British Library's version. This version is no longer bound, having been separated from one album, but still holds all of the plates and corresponding texts. How the album came to the Wilbour Library is yet to be confirmed.

The AMC album Photographic Views Taken in Nubia is a version of volume two of the master set, but does not have a photograph on its title page. The album was purchased as a set with Photographic Views Taken in Egypt at the AMC from a private antiquarian book dealer in New York in 2012. Photographic Views Taken in Egypt at the AMC is a selection of prints from both volumes of the master set. The album does not have a table of contents. The image on the title page displays James Douglas Jr., Naomi Douglas, and James Douglas, M.D. seated, while an unidentified boy in the background holds a rifle. Photographic Views of Egypt \& Nubia was purchased by the AMC in 2009 from the Wilkens Estate Auctions in Toronto. The album does not have a table of contents, but has a title page with a photograph titled "Our Nile Boat" displayed instead, next to its accompanying text (see Figure 5).

The album at Université Laval holds a selection of 36 albumen photographs from both volumes of the master set. The album's binding is similar to the AMC's Photographic Views of Egypt \& Nubia. The album is inscribed by James Douglas, M.D. and is dedicated to Dr. Landry. While there is no information about how the album came into the collection of the Pavillon JeanCharles-Bonenfant Library at the Université Laval, it is assumed that Dr. Landry's family 
donated the album to the Pavillon Jean-Charles-Bonenfant Library at the Université Laval sometime between 1968 (when the library was created) and 1980-81. The album does not have a table of contents and also has a title page with a photograph titled "Our Nile Boat" on it instead of directly placed next to its accompanying text.

\section{Description of the Collection}

The typed titles of the photographs are taken directly from the albums at the AMC.

Photographic Views in Egypt \& Nubia

Our Nile Boat

Statue of Rameses

Pyramid of Sakhara

Tombs of Beni Hassan

Old Goornah

Thothmosium

Dayr El Medeenet

Judgment Scene

Medeenet Habou

Medeenet Habou (Second Court)

Medeenet Habou (General View)

The Colossi

Luxor (Obelisk)

Karnac (From the East)

Karnac (Great Southern Temple)

Esné,

The Pyramid of El-Kufeh

El-Kab

Edfoo (Front View of the Temple)

Edfoo (Bird's Eye View)

Kom Ombros (The Temple)

Philæ (From the North)

Philæ (Dahabiehs- at the Landing Place, under the Hypæthral Temple)

Philæ (General View)

Philæ (Colonnade)

Philæ (Propylon)

Tafa

Gertassee (Quarries)

Dakkah

Maharaka (Temple)

Sabooa

Korusko

Crude Brick Building

Desert Scene in Nubia

Ibreem

Roman Castle of Ibreem 
Queen's Temple at Abou Simbel

Abou Simbel

Abou Simbel (Two Northernly Colossi)

Photographic Views Taken in Nubia

Assouan (The Ancient Syene)

Island of Elephantine

First Cataract

First Cataract (Second View)

Landing Place at El Shellal

Canjia

Philæ (From the North)

Philæ (Dahabiehs- at the Landing Place, under the Hypæthral Temple)

Philæ (General View)

Philæ (Hypæthral Temple)

Philæ (Propylon)

Philæ (Colonnade)

Philæ (From the South)

Gertassee

Gertassee (Quarries)

Tafa

Kalabashe

Dendoor

Dakkah

Maharaka (Temple)

Sabooa

Korusko

Caravan Road from Korusko

Christian Graves

Amada

Crude Brick Building

Desert Scene in Nubia

Ibreem

Roman Castle of Ibreem

Queen's Temple at Abou Simbel

Abou Simbel

Abou Simbel (Colossal Statue)

Abou Simbel (Two Northernly Colossi)

Rameses Slaying His Enemies

Photographic Views Taken in Egypt

Our Nile Boat or Dahabieh

Boulak

The Stone Pyramid of Dashoor

Minieh

Tombs Near Osioot

Girgeh 


\section{Old Goornah}

Valley of the Tombs of the Kings

Mummies

Rameseum (Colossal Statue)

Luxor (Mustapha Aga)

Karnac (From the East)

Karnac (General View)

The Pyramid of El Kufeh

El-Kab

Edfoo (Screen)

Kom Ombros (The Temple)

Kom Ombros (Temple Enclosure)

Island of Elephantine

First Cataract

Landing Place at El Shellal

Philæ (Dahabiehs- at the Landing Place, under the Hypæthral Temple)

Philæ (Propylon)

Gertassee

Tafa

Dendoor

Christian Graves

Korusko

Amada

Crude Brick Building

Roman Castle of Ibreem

Desert Scene in Nubia

Abou Simbel 


\section{PHOTOGRAPHY IN EGYPT DURING THE 1850s AND 1860s}

The beauty and mystery of Egypt's ancient ruins and hieroglyphs have long fascinated Westerners. Since Napoleon's Egyptian campaign (1798-1801), its resulting publication Description de l'Égypte (1809-1813), and the discovery of the Rosetta Stone in 1799, that provided the key to decoding the hieroglyphs, Egypt became a destination for artists and travellers to document and explore, and the field of Egyptology was born. ${ }^{24}$ Photography's ability to aid in the documentation and study of Egypt was first made apparent in François Arago's presentation of the daguerreotype process in January 1839 to the French Academy of Sciences, where he explained photography's ability to record the sites and hieroglyphs of Egypt. ${ }^{25}$ Photography catalyzed Orientalist studies and explorations to Egypt, first encouraged and supported by the French government in official or semiofficial missions. ${ }^{26}$

The number of photographers and travellers to Egypt was also influenced by societal and economic transformations, as the Industrial Revolution in Europe offered more opportunities for traveling abroad. By 1835, regular steamship service was offered between Europe and Egypt, making the journey across the Mediterranean a more frequented and much easier trip. ${ }^{27}$ Another factor that contributed to an increase in tourism and travel was the growth of railway travel within Egypt from Alexandria to Cairo, beginning in $1855 .{ }^{28}$ A number of these contributing factors, including other social, economic, and political events of the time shaped photography in Egypt during the 1850 s and 1860 s. However, it is important to note that this chapter will only serve to briefly mention these influences, as the purpose of this section is to contextualize James Douglas Sr. and James Douglas Jr. within the realm of photographers in Egypt between 1850-1900. Four notable photographers who photographed Egypt will be used to create a background that situates the Douglas albums and some of their photographic content: Maxime Du Camp, Félix Teynard, J.B. Greene, and Francis Frith.

During the 1850s and 1860s, photographers primarily used two different processes either the calotype process that employed paper negatives or the wet plate collodion process that

\footnotetext{
$24 \quad$ Nissan N. Perez, Focus East: Early Photography in the Near East 1839-1885, 36 \& 26. Ibid., 15. Ibid., 36. Kathleen Stewart Howe, Excursions Along the Nile: The Photographic Discovery of Ancient Egypt, 29. 28 Ibid., 30 .
} 
used negatives made on glass plates. Calotypes, also known as Talbotypes, were invented in the late 1830 s and patented by William Henry Fox Talbot in $1841 .{ }^{29}$ The calotype process was used from 1841 to $1860 .{ }^{30}$ An adaptation of the process called the waxed paper negative process was created by Gustave Le Gray and published in 1851; this process allowed photographers to prepare and sensitize their negatives in advance. ${ }^{31}$ Each negative was treated with molten wax before it was sensitized, which helped both the translucency and the preservation of the sensitivity of the negative over several days, aiding in the pursuits of travelling photographers. ${ }^{32}$ The collodion wet-plate process, on the other hand, was invented by Frederick Scott Archer in 1848, and published in $1851 .{ }^{33}$ Between 1851 and 1885 collodion negatives were popularized, and surpassed the use of the paper negative due to their greater sensitivity and resolution. ${ }^{34}$ However, because the exposure had to occur while the plate was wet, collodion was cumbersome and difficult to carry out successfully, especially in dry, hot climates like those found in Egypt.

The decision to use either calotypes or collodion by photographers in Egypt may have been influenced by multiple factors. Nissan Perez in Focus East: Early Photography in the Near East 1839-1885 grounds the choice of processes in the "sensibilities within the photographer's country of origin. In addition to local photographic traditions that developed, art and visual literacy in each country influenced how the photographers worked," with French photographers typically making calotypes, and British photographers often using collodion. ${ }^{35}$ Other factors influencing the photographer's decision to use either calotypes or collodion would have been whom they learned from, how difficult the process was, aesthetic concerns, and the purpose of the photographs. The Douglases used waxed paper negatives to create their photographs, as explained in a corresponding text to the photograph "Philæ (Colonnade)" written by James Douglas Jr.:

We employed the simplest of the wax paper processes, which is preferable on several accounts. In the first place, the sensitized sheets keep good for some length of time... But the great advantage of the paper process is the absence of ether and other volatile substances, which make the employment of collodion in Egypt almost

\footnotetext{
29 Bertrand Lavédrine, Photographs of the Past: Process and Preservation (Los Angeles: Getty Conservation Institute, 2009), 224.

$30 \quad$ Ibid., 224.

31 Ibid., 224.

32 Ibid., 224.

33 Ibid., 238.

$34 \quad$ Ibid., 238.

35 Nissan N. Perez, Focus East: Early Photography in the Near East 1839-1885, 81.
} 
impossible, and most painful from the rapid evaporation caused by the intense heat and dryness of the climate. ${ }^{36}$

Although it is possible there were other contributing factors in the Douglases' decision to use waxed paper negatives, it is evident that the difficulty of using collodion in Egypt's hot and dry climate was a significant influence.

The photographer Maxime Du Camp, under commission by the Ministry of Public Education of the French government, published Égypte, Nubie, Palestine et Syrie: dessins photographiques recuillis pendant les années 1849, 1850, et 1851, accompagnés d'un texte explicatif in $1852 .{ }^{37}$ Du Camp had been a student of Gustave Le Gray, the creator of the waxed paper negative process. ${ }^{38}$ However, Du Camp was not successful with Le Gray's technique and preferred a variation of the wet paper process, created by Louis-Désiré Blanquart-Évrard in 1847, to make his negatives..$^{39}$ Of the 214 successful negatives taken over the course of Du Camp's travels, 125 negatives were published and printed by Blanquart-Évrard and 94 of those were of Egypt. ${ }^{40}$ Asserting that these types of views would be of greater fascination to audiences, Du Camp's publisher selected photographs that focused on views of ancient Egypt as opposed to views of Egypt's villages and inhabitants. The majority of the 94 photographs had ancient monuments as their subjects. ${ }^{41}$ Intended as "precise scientific records", many of the photographs of monuments were requested by the French Academy of Inscriptions for the documentation of inscriptions ${ }^{42}$ Du Camp's publication and photographs were shaped by the specific views and sites requested, selected and eliminated. Similarly, views printed by the Douglases can be considered a shaped and edited version of Egypt, as James Douglas Jr. writes in the text that accompanies "Philæ (Colonnade)":

Below Cairo every attempt to succeed proved fruitless owing to my own inexperience. The collection therefore gives a most inadequate idea of the architecture of modern Egypt. I accordingly afterwards confined myself almost exclusively to the photography of the old remains, it being impossible to do justice to every feature of the Nile during one trip. Of almost all the Monuments we therefore

\footnotetext{
$36 \quad$ James Douglas Jr., Photographic Views Taken in Nubia, 13.

37 Kathleen Stewart Howe, Excursions Along the Nile: The Photographic Discovery of Ancient Egypt, 27.

38 Ibid., 26.

39 Bertrand Lavédrine, Photographs of the Past: Process and Preservation, 224

$40 \quad$ Kathleen Stewart Howe, Excursions Along the Nile: The Photographic Discovery of Ancient Egypt, 27.

$41 \quad$ Ibid., 27.

$42 \quad$ Ibid., 27
} 
selected that view which would give the best idea of the whole, and there are few of any consequence which are not represented. ${ }^{43}$

While the views taken are reflective of the time restrictions, weather conditions and the photographers' technical capabilities, the Douglases, similar to Du Camp, had unsuccessful negatives and were not able to represent the entirety of Egypt in one publication. Additionally, Du Camp's book also holds accompanying text comprised of travel narratives published alongside photographs, as do the Douglas albums. Ali Behdad argues in "The Orientalist Photograph" published in Photography's Orientalism: New Essays on Colonial Representation that these texts "[made Du Camp's] images meaningful and legible" and helped to "determine what is worthy of photography in the Middle East" ${ }^{44}$ Du Camp's book was the first book on Egypt illustrated with photographs and established a precedent for how Egypt could be documented photographically, and if the Douglases saw these images, they would have been able to follow certain photographic standards established by Du Camp.

Photographer Félix Teynard published Égypte et Nubie from 1853 to 1858 by Goupil et Cie as a photographic 'complement' to Description de l'Égypte (1809-1813), the resulting publication made from Napoleon's Egyptian Campaign, which was undertaken before photography's invention. ${ }^{45}$ The publication, composed of 160 salted paper prints, served as a "photographic catalogue of ancient and modern Egypt in terms of the Description [de l'Égypte (1809-1813)]." 46 Teynard, like Du Camp, trained under Gustave Le Grey, and worked mostly with waxed paper negatives. Teynard has described his photographs of modern buildings and ancient sites as 'souvenirs' that have 'registered' his 'sensations' ${ }^{47}$ Similar to the work of Teynard, the Douglas albums serve a type of visual souvenir, creating mementos of the sites of Egypt. However, while Teynard's work is often described as illustrating poetic or emotional expressions, the photographs themselves, like the Douglas albums, were meant to illustrate a descriptive text on Egypt. The Douglases believed their photographs offered an illustrative purpose, inferior in importance to their accompanying text. James Douglas Jr. writes in the accompanying text to "Philæ (Colonnade)", "Photography being quite a subordinate object with us, we never left the beaten tract nor did we ever delay an hour for the mere purpose of taking a

$43 \quad$ James Douglas Jr., Photographic Views Taken in Nubia, 13.

$44 \quad$ Ali Behdad, "The Orientalist Photograph," Photography's Orientalism: New Essays on Colonial Representation (Los Angeles: Getty Research Institute, 2013), 16.

45 Kathleen Stewart Howe, Excursions Along the Nile: The Photographic Discovery of Ancient Egypt, 27.

$46 \quad$ Ibid., 27.

47 Ibid., 27. 
view." ${ }^{48}$ Although James Douglas Jr. takes a humble approach in discussing his and his father's use of photography, their work was given to family members and to coworkers as gifts, revealing that the Douglases were pleased with the albums, and when James Douglas Jr. donated a family copy to the British Museum in 1908, he would have perceived the albums as culturally valuable objects. Teynard's photographic books were sold for one thousand gold francs, a very costly purchase at the time, and this may contribute to their rarity and value today. ${ }^{49}$ While a photographer's valuation of his or her own photographs has some influence over their fate, Teynard's and the Douglases' photographs also illustrate that meaning and worth can be derived from other aspects of the objects themselves; Teynard deriving meaning from Napoleon's Description de l'Égypte and the Douglases supporting their photographs with their text.

J.B. Greene, another one of Gustave Le Gray's students, photographed Egypt using waxed paper negatives in 1853 and had 94 of his photographs published as Le Nil, monuments, paysages, explorations photographiques par J.B. Greene by Blanquart-Évrard in $1854 .{ }^{50}$ Greene also gave selections of these photographs to the French Academy of Inscriptions. ${ }^{51}$ In 1855 , Greene returned to Egypt to photograph an excavation that he conducted at Medinet-Habu, making him the first practicing archeologist to document an archeological dig with photographs. The results of this dig were published in Fouilles éxecutées à Thebes dans l'année 1855 and given to the Institute of France. ${ }^{52}$ With an interest in the precise documentation of sites in Egypt and the capturing of atmospheric landscapes, Greene's images have been interpreted as serving scientific and documentary purposes as well as artistic pursuits, as Greene himself held one file for his photographs of monuments and inscriptions, and another for his landscape studies ${ }^{53}$ How Greene's work is now perceived illustrates the discussion and acceptance of both styles in an academic context. The Douglas photographs, which provide both comprehensive and documentary views of sites and landscapes as well as fragmentary, close-up views of architecture and Egyptian art, can be understood and discussed in the same terms as the work of Greene, Teynard and Du Camp. When situated amongst these celebrated photographers, the possibilities for contemporary discourse are apparent and it is my hope that they will be explored by future researchers.

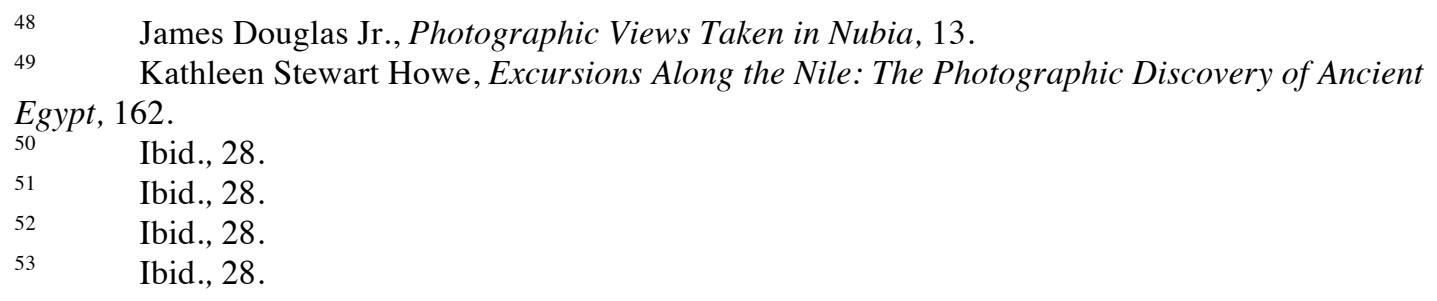


The photographer Francis Frith documented Egypt using wet collodion glass plate negatives while travelling to Egypt two times, the first in 1856-1857 and the second in 18591860. The first trip resulted in the publication Egypt and Palestine Photographed and Described by Francis Frith published from 1858-1860 and contained 76 albumen prints. ${ }^{54}$ Text written by Frith accompanied each sharp and detailed photograph explaining interesting aspects within the image and providing the reader with a better sense of experiencing Egypt first-hand, allowing for, "a simulated Nile voyage for the entertainment and edification of Victorian households." 55 The circumstances of Frith's interest and training in photography remain uncertain. ${ }^{56}$ Frith would create many commercial publications, as the greater reproducibility of wet collodion glass plate negatives greatly added to the practice of commercial photography. While the work of Francis Frith is predominantly understood through his commercial ventures, before Frith photographed commercially, he was considered an amateur photographer, as Douglas Nickel writes in Francis Frith in Egypt and Palestine: A Victorian Photographer Abroad:

Initially Frith left England an amateur, with modest expectations for photographic success. He and Wenham, by their own account, construed their project as technical and experimental, intended to produce imagery (if any resulted at all) that was evidently directed at a relatively narrow circle of friends and like-minded colleagues...In this regard they anticipate the mnemonic function that would later be associated with the snapshot: the group is disposed in such a way as to proclaim, more than anything else, that the site had actually been reached: here was the proof..$^{57}$

While Frith would go on to expand his artistic role and develop certain stylistic choices, his initial visit to Egypt was composed of views that displayed Westerners, which he would later eliminate from his compositions in his subsequent travels portraying a "timeless East, ostensibly untrammeled by the modern world" ${ }^{58}$ The Douglas albums, which contain images of sites with themselves, locals, and family members in their photographs, better align with the work from Frith's first visit, whose experimental photographs show evidence of the sites that he was witness to.

$54 \quad$ Kathleen Stewart Howe, Excursions Along the Nile: The Photographic Discovery of Ancient Egypt, 159.

55 Ibid., 43.

56 Douglas R. Nickel, Francis Frith in Egypt and Palestine: A Victorian Photographer Abroad (Princeton, NJ: Princeton UP, 2004), 44.

$57 \quad$ Ibid., 67.

$58 \quad$ Ibid., 68. 
By 1860, photography in Egypt was dominated by commercial interests that shaped the types of views taken of Egyptian sites, moving from photographic 'scientific' documents to travel albums made of purchased photographs. ${ }^{59}$ This type of photography was influenced by the popularization of tourism along the Nile, standardized in the mid-1850s by itineraries through guidebooks and organized tours that became available to the middle classes. ${ }^{60}$ The creation of the Tour du Monde, personalized travel albums in which commercial souvenir photographs were made, helped to satisfy this demand, stimulating a need for commercial, souvenir images for the surge in tourists. ${ }^{61}$ It is in this respect that the Douglas albums, views taken in the winter of 18601861 , illustrate an interesting perspective: they are personal travel albums that include both comprehensive views and close-up details, that in many respects resemble certain elements of the works of Frith, Greene, Teynard, and Du Camp. However, these works predate the Douglas albums and they had already documented Egypt. The Douglases could have commissioned photographs or purchased commercial views to go alongside the text that they wrote. It is the fact that the photographs were neither commissioned nor purchased by any professional photographer when these resources were available to them, that lends these albums their unique perspective. Since the Douglas albums were created later, it is probable that the mentioned photographers likely influenced them. The Douglas albums display various formal qualities that became standard in the documentation of the topography of Egypt. While the Douglas albums are not mentioned in the history of photography, it is imperative that they are introduced into the discussion on how photography in Egypt advanced, as their albums were made during an important and evolving period of the history of photography in Egypt.

$59 \quad$ Kathleen Stewart Howe, Excursions Along the Nile: The Photographic Discovery of Ancient Egypt, 35-36.

60 Ibid., 30 .

$61 \quad$ Ibid., 36. 


\section{FINDINGS, COMPARISON, AND DISCUSSION}

The following section discusses findings that are significant to the understanding and examination of the Douglas albums, and also establishes a comparative context in which the albums can be considered. Using examples by photographers Francis Frith, Maxime Du Camp, Félix Teynard, J.B. Greene, and James Douglas, M.D. and James Douglas Jr., this section will demonstrate both the similarities and differences apparent in the documentation of Egypt in the 1850s and 1860s. This comparison can be adapted to explore how the Douglases' photographs can be analyzed and discussed in relation to their contemporaries, and can be expanded into a discussion on topographic and travel photography in the $21^{\text {st }}$ century.

\section{Findings}

Section $i$.

While examining the Douglas albums at the British Library, I discovered a dated watermark (1862 BFK Rives No. 46) on the print titled "Gertassee- Quarries". This watermark helps to identify the paper the photograph is printed on as "Rives" paper from the company Blanchet Frères et Klébler Co. manufactured in Rives, France. This watermark verifies that the prints were likely printed around 1862, a date that corresponds to the cataloguing dates for all versions of this album. However, on my visit to Université Laval, I found the same watermark from BFK Rives dated from 1872 or 1874 . This date, along with the dated and handwritten dedication made by James Douglas, M.D. to Dr. Landry from December $25^{\text {th }} 1874$ displayed in Figure 1, suggests that the album and the prints from Université Laval were assembled and printed at least a decade later than the albums held by the British Library. The AMC album Photographic Views in Egypt \& Nubia has a handwritten dedication by James Douglas, M.D. to Dr. Russell, the original recipient of the album. This dedication also includes a date of December $25^{\text {th }} 1874$. The two inscriptions, the second visible in Figure 2, indicate that the albums were presented as gifts on the same date. Due to their identical dates and visual similarities, (see Figure 3), it is very likely to conclude that both albums were printed and assembled in 1872 or 1874 .

Another fact that may support the suggestion that both the Université Laval and the AMC albums were created at a later date, is that each of the title pages displays a cropped version of the image "Our Nile Boat" on the title page instead of placing it in the album, displayed in Figures 3 
and 4, as it was for the albums in the collections of the British Library, the Wilbour Library of Egyptology, and the AMC's album Photographic Views Taken in Egypt. This may have been a decision made by the Douglas family possibly after viewing Francis Frith's 1862 publication Lower Egypt, Thebes, and the Pyramids, where the photograph titled "Traveller's boat at Ibrim" taken in 1857, seen in Figure 5, is displayed on the title page. The image, similar to the Douglases' "Our Nile Boat", focuses on a boat with raised sails stationed close to shore. It is quite possible that the Douglas family came into contact with the commercially available albums of Egypt that Frith produced after creating their own albums in 1862. The Douglas albums that were assembled and printed in 1862 either hold title pages with photographs of the members of the Douglas family, like in the British Library albums and the AMC's Photographic Views Taken in Egypt, or do not hold any photographs on their title pages at all, such as in the Wilbour Library of Egyptology's album and the AMC's Photographic Views Taken in Nubia. The decision to use "Our Nile Boat" on the title pages in the albums at the Universite Laval album and in the AMC's Photographic Views in Egypt \& Nubia illustrates an aesthetic change in the appearance of the albums. It is possible the Douglases no longer had access to the negatives of the family portraits used in 1862, and substituted these images with "Our Nile Boat" after seeing and being influenced by Frith's popular albums. While this is only speculation, it is evident that there is an aesthetic difference particularly in the treatment of the title pages between those made in 1862 and the others that were likely produced in 1874.

\section{Section ii.}

While at Université Laval I was introduced to the NOVA film, The Mummy Who Would be King. The film traces the lineage of a mummy that was brought to the Niagara Falls Museum in Canada by James Douglas, M.D. and is believed to be the remains of King Rameses I. The connection between the Niagara Falls Museum and the royal mummy was established through the Université Laval's version of the Douglas album. In the text titled "Luxor- Mustapha Aga", present in Université Laval's album, it is discussed that James Douglas, M.D. was paid to bring mummies back to Canada for a man named Mr. Barnett who owned the Niagara Falls Museum. ${ }^{62}$ James Douglas, M.D. notes that a man named Mustapha Aga, visible in the photograph that accompanies the text, was able to procure antiquities and mummies for Western travellers as the

62 In the text "Luxor- Mustapha Aga" James Douglas, M.D. writes when discussing the purchase of mummies: "During my last visit, I obtained a finer one, in double cases, for Mr. Barnett, of Niagara Museum, for seven pounds". 
titular British Vice-Consul at Thebes. As the narrator for the film The Mummy Who Would be King explains, "Douglas boasted about buying a "fine" mummy for the Niagara Falls Museum. He also wrote about one of his contacts in the antiquities trade: Mustapha Aga, a notorious middleman between tourists and tomb robbers." ${ }^{63}$ The photograph and text in the Université Laval album strongly suggest that James Douglas, M.D. was the intermediary between Egypt and Mr. Barnett. They also lend support to the claim of the mummy's royal heritage, and provide another dimension to the cultural and historical importance of the albums. Another image of Musapha Aga, this time with his family seated in from of a colonnade, was used in the film and can be seen in Figure 7. It is interesting to note that because the album at Université Laval is not a master set, not all the photographs made by the Douglases are included in the album. For instance, the photograph titled "Mummies", a photograph of the mummies James Douglas, M.D. brought back to the Niagara Falls museum seen in Figure 8, was not included in the Université Laval album and as a result, was unfortunately not consulted by the NOVA producers.

\section{Comparison and Discussion}

This section uses two images to illustrate a comparative analysis of the Photographic Views Taken in Egypt with photographs made by more famous contemporaries of the Douglases. Each image selected for comparison was chosen for a distinct purpose. The first is an image by the Douglases of a monument that, as the Douglases assert, was not documented before them. The second image is of a monument popularly photographed by photographers before the Douglases.

\section{Section $i$.}

"Crude Brick Building"

The photograph titled "Crude Brick Building" displayed in Figures 9 and 10 depicts James Douglas, M.D., James Douglas Jr. and an unidentified male figure. The photograph provides a comprehensive view of a brick building of Roman masonry, and according to the Douglas family, none of the literature that they consulted before visiting Egypt discusses this site. In the corresponding text to the photograph James Douglas, M.D. explains, "We were surprised that it has not been noticed or described by Irby \& Maugles, Belzoni, Sir G. Wilkinson, or any

63 The Mummy Who Would Be King. Directed by Gail Willumsen. 2005. NOVA Productions, January 3, 2006. VHS. 
other traveller with whose works we were acquainted." ${ }^{64}$ Following this assumption, the photograph of and text about the site are presumed to be uninfluenced by any other photograph or writing in history, which indicates a truly original perspective in its presentation. The decision to include themselves in the image suggests the Douglases' wished to be a part of the documentation of the site. The photograph illustrates the whole building, instead of a fragmentary view, which implies that there was a rationale concerned with recording the site in its entirety. Whether or not the Douglases were the first travellers with a camera to visit this site is unknown; however, their approach to photographing the site is indicative of a style that follows the trajectory of topographic views from the $19^{\text {th }}$ century into the $21^{\text {st }}$ century. The level framing and the distant perspective capture an image that provides an easily-read view that describes the visual qualities of the landscape.

Section ii.

"Kom Ombos- Temple"

Maxime Du Camp, Félix Teynard, Francis Frith, J.B. Greene and James Douglas, M.D. and James Douglas Jr. have all documented the town of Kom Ombo, a popular site for photographers and tourists to visit. James Douglas and James Douglas Jr. photographed both the temple and the temple enclosure in Kom Ombo. The temple of Kom Ombo has been of specific interest for photographers; its ancient ruins and dilapidated structure appealed to those interested in recording crumbling man-made monuments. The photographers Frith, Teynard, Du Camp, Greene and the Douglases photographed the temple similarly, with "Ruines du Temple de KoumOmbou (Ombos)" in 1849-1850 by Maxime Du Camp, "General View of the Ruins, Kom-Ombo" in 1851-1852 by Félix Teynard, "Temple d'Ombos" between 1850 and 1855 by J.B. Greene, “Koum Ombo- Near View" ca. 1857 by Francis Frith, and "Kom Ombos- Temple” in 1860-1861 by James Douglas, M.D. and James Douglas Jr. While each photograph's perspective of the temple only differs by a few metres, the approach taken to frame the monument is unanimous: concise and level framing that illustrates both the top and bottom of the temple. The distance from the monument to the camera is difficult to establish exactly, but comparatively, Du Camp, Frith and the Douglases illustrate the temple from a closer vantage point than Greene and Teynard. Frith's photograph, seen in Figure 11, is the only photograph that depicts people at the 
base of the temple; however, in an 1858 photograph entitled "Temple at Koum Ombos" Frith has eliminated any human presence from the view. When compared to the four other photographs, the Douglases' photograph, seen in Figure 12, presents strong stylistic parallels. This indicates that either the Douglases were influenced by the photographs made before them, or that their photographic style developed from a need to capture a view of a place or monument in its entirety, using photographs to best illustrate and record the landscape for viewers unfamiliar with the topography of Egypt. 


\section{CONCLUSION}

This project concentrated on building a foundation on which the albums Photographic Views Taken in Egypt created by James Douglas, M.D. and his son James Douglas Jr., could be considered in an academic context. As the albums were privately published and disseminated primarily to the friends and family of the photographers, writings on these photographic works have been restricted and the Douglas family's legacy has principally been discussed with regard to their other accomplishments, instead of their photographic endeavors. As a result, the contextualization, comparisons and discussion of my findings all contribute to the understanding of Photographic Views Taken in Egypt as important photographic objects in the study of $19^{\text {th }}$ century photography in Egypt. Through the examination of the different albums at the Archive of Modern Conflict, the British Library, the Brooklyn Museum's Wilbour Library of Egyptology Special Collections and Université Laval, crucial information about the albums became apparent and contributed to a greater comprehension of the possible aesthetic choices made by the Douglas family. The visual similarities that exist between the Douglases' photographs and those of their contemporaries are striking, and it is my hope that this project catalyzes a discourse on the aesthetic parallels found in the work of photographers documenting the landscapes and monuments of Egypt from the $19^{\text {th }}$ century onwards into the $21^{\text {st }}$ century.

While I attempted to examine as much material pertaining to the Douglas family photographers as possible, there are still unanswered questions and other resources on the family that I was unable to consult. Although each of the texts in the Douglas albums is initialed, the photographs that James Douglas Jr. authored or James Douglas Sr. authored is unknown. For future researchers, the Arizona Historical Society holds "Douglas papers, 1880-1938" which I believe would be valuable in providing further insight into the Douglas family. In the city of Douglas, Arizona, the Douglas-Williams House Museum, which was the home of James Douglas Jr.'s son, James Stuart Douglas from 1908 to 1943, holds collections on the Douglas family and a photographic archive, which would be valuable for further study. Both of these resources could provide a greater understanding on Photographic Views Taken in Egypt, and perhaps, any other photographic undertakings the Douglases may have had. 
APPENDIX A:

FIGURES 


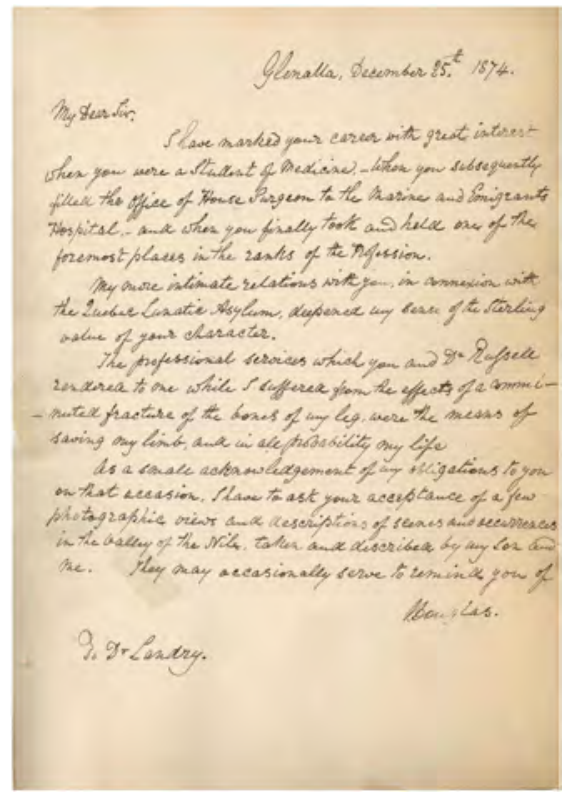

Figure 1. Inscription to Dr. Landry by James Douglas, M.D. in Photographic Views in Egypt \& Nubia. Image courtesy of Université Laval.

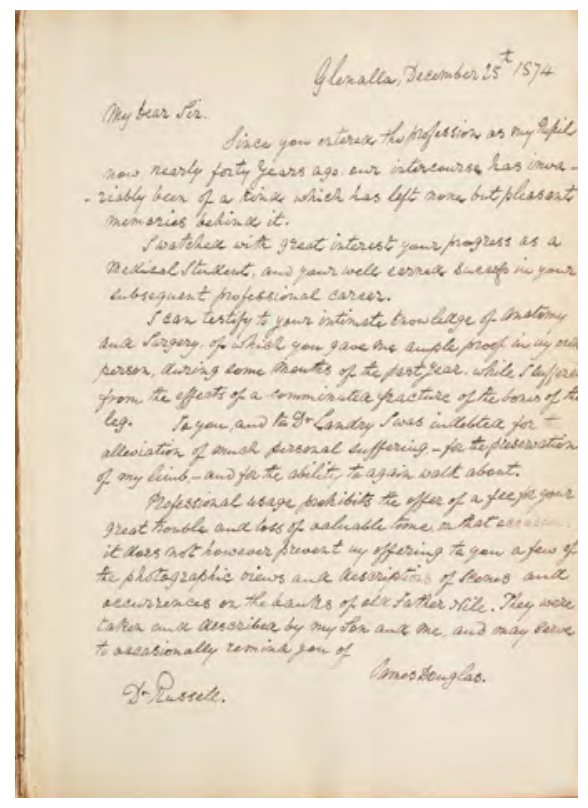

Figure 2. Inscription to Dr. Russell by James Douglas, M.D. in Photographic Views in Egypt \& Nubia. Image courtesy of AMC. 


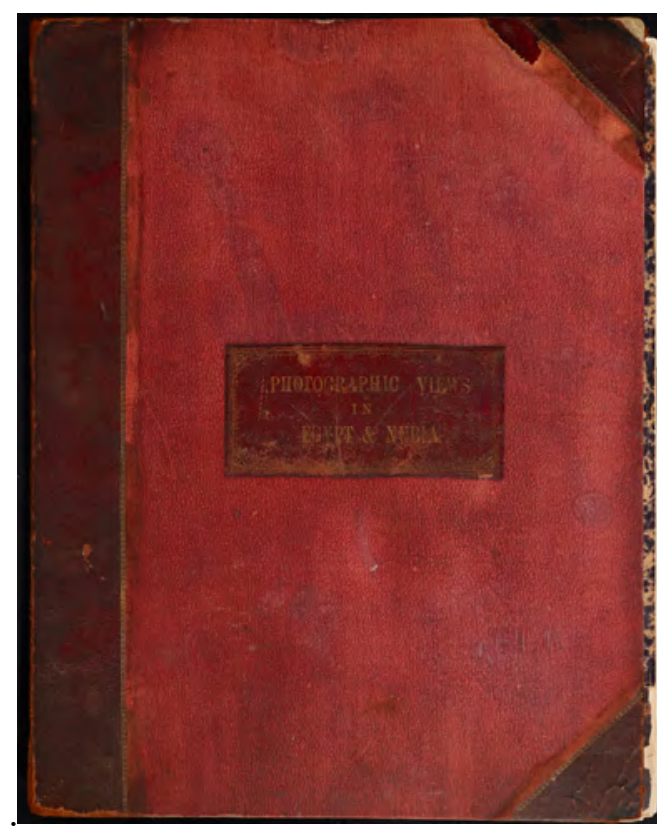

Figure 3a. Cover of Photographic Views in Egypt \& Nubia. Image courtesy of AMC.

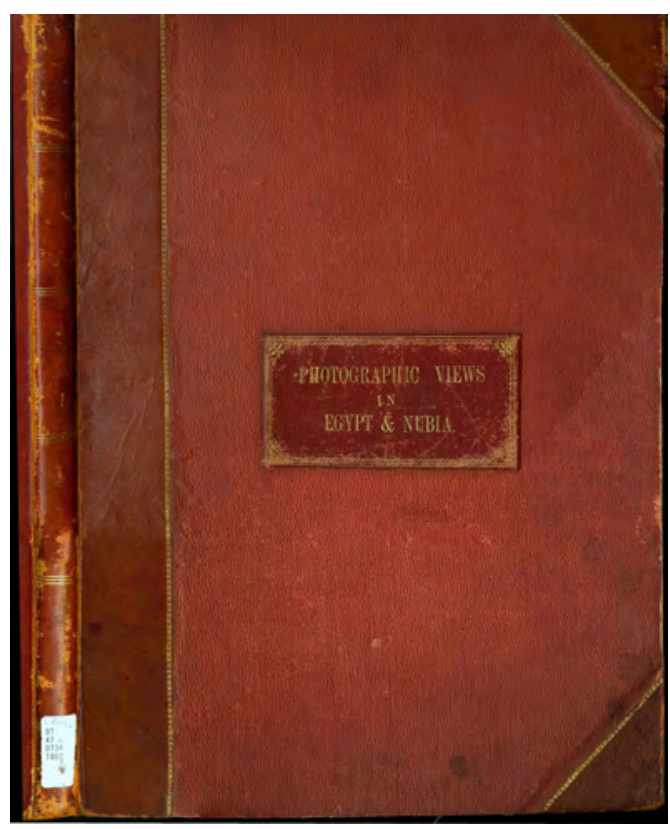

Figure 3b. Cover of Photographic Views in Egypt \& Nubia. Image courtesy of Université Laval. 


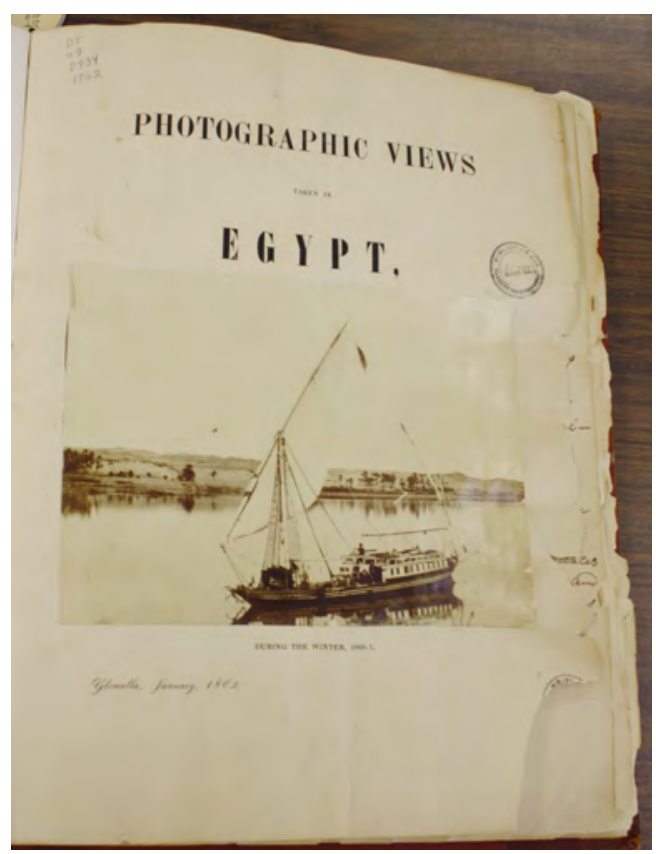

Figure 4. Title page from Photographic Views of Egypt \& Nubia with the photograph "Our Nile Boat" by James Douglas, M.D. and James Douglas Jr. Image courtesy of Université Laval.

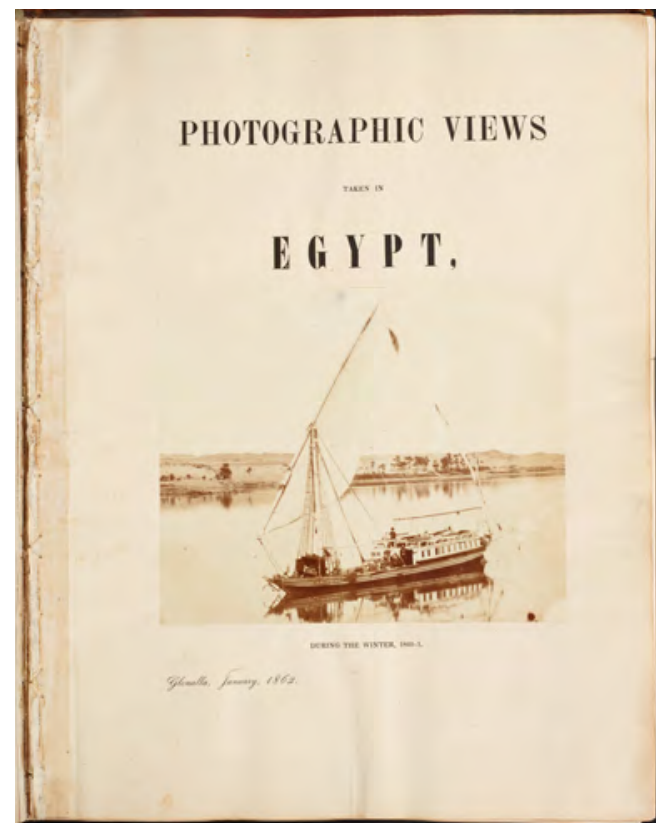

Figure 5. Title page from Photographic Views in Egypt \& Nubia with the photograph "Our Nile Boat” by James Douglas, M.D. and James Douglas Jr. Image Courtesy of AMC. 


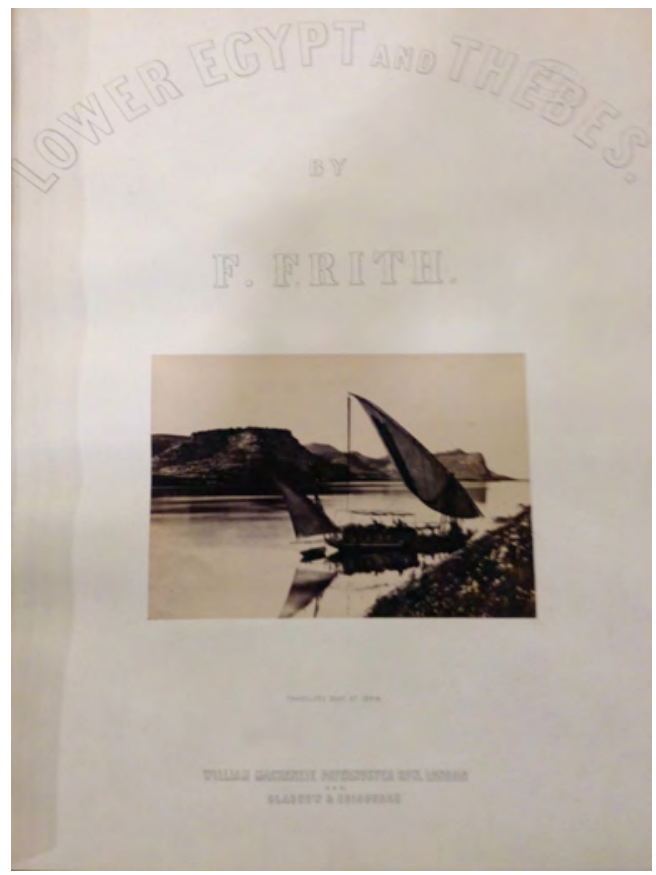

Figure 6. Title page from the ca. 1862 publication Lower Egypt, Thebes, and the Pyramids by Francis Frith with the photograph titled "Traveller's boat at Ibrim" taken in 1857. Image courtesy of the Toronto Public Library.

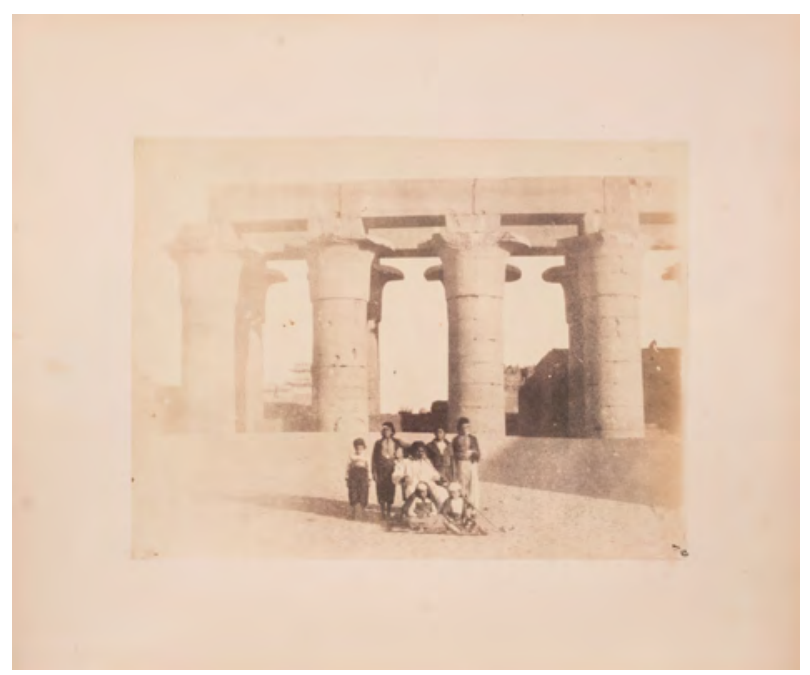

Figure 7. "Luxor- Mustapha Aga" by James Douglas, M.D. and James Douglas Jr. Image courtesy of AMC. 


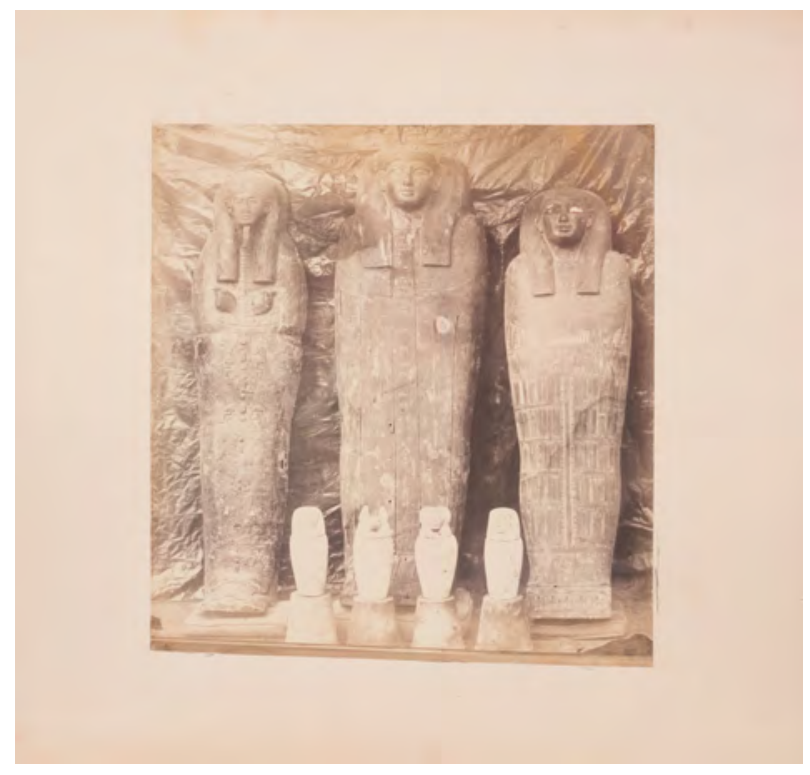

Figure 8. "Mummies" by James Douglas, M.D. and James Douglas Jr. Image courtesy of AMC.

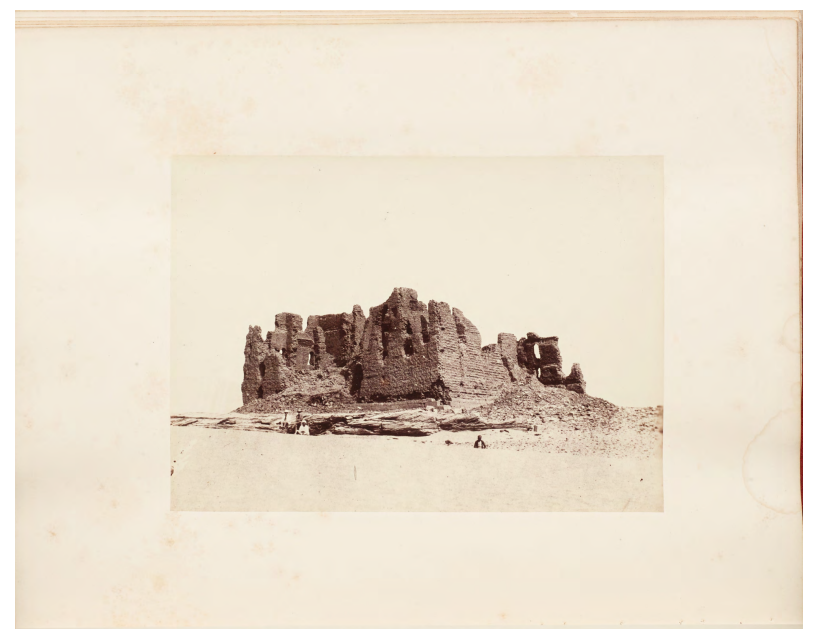

Figure 9. "Crude Brick Building" by James Douglas, M.D. and James Douglas Jr. Image courtesy of AMC. 


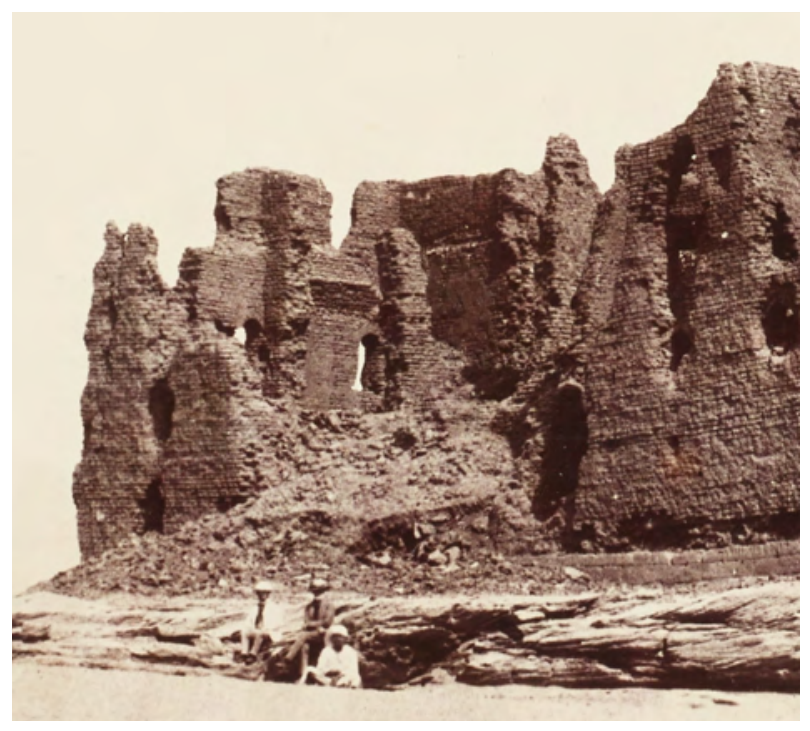

Figure 10. Detail of "Crude Brick Building” by James Douglas, M.D. and James Douglas Jr. Image courtesy of AMC.

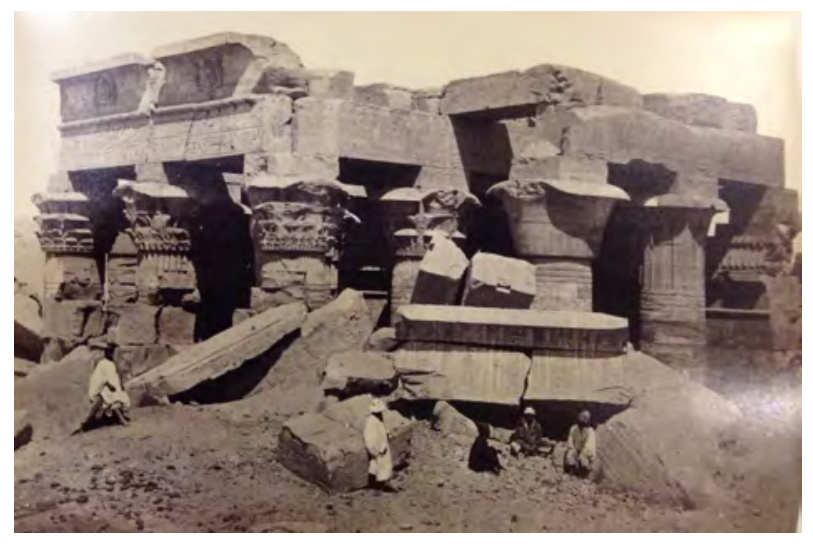

Figure 11. "Koum Ombo- Near View" from the ca. 1862 publication Upper Egypt and Ethiopia by Francis Frith taken in ca. 1857. Image courtesy of the Toronto Public Library. 


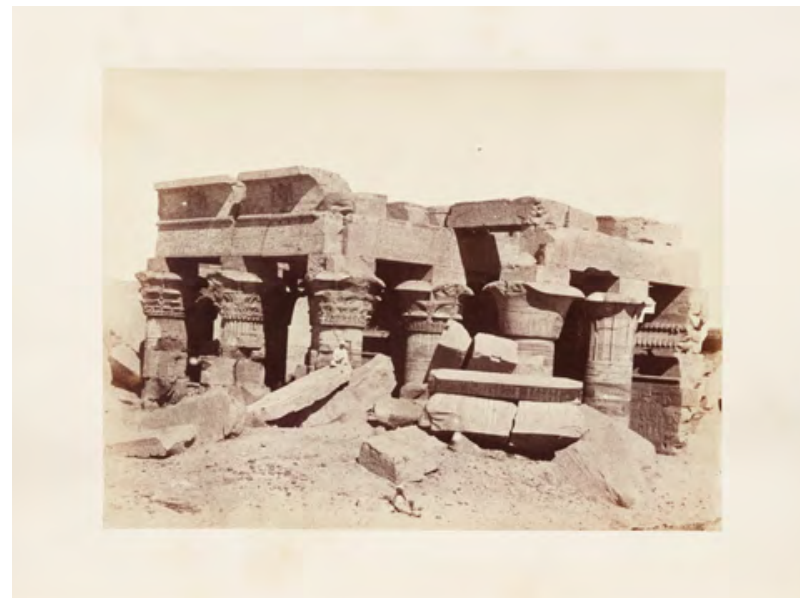

Figure 12. "Kom Ombos- Temple" by James Douglas, M.D. and James Douglas Jr. Image courtesy of AMC. 
APPENDIX B:

CONCORDANCE OF IMAGES AND TEXT IN PHOTOGRAPHIC VIEWS TAKEN IN EGYPT 


\section{CONCORDANCE METHODOLOGY}

I have cropped images to display the prints more clearly, but the crops do not show the objects in their truest format. The images are in albums, with the image placed on the left side of the album and the text beside the image on the right side of the album. The images are displayed vertically, but are read horizontally, with the bottom of each photograph directly facing the accompanying page. If the album has a title page with an image, the photograph is presented and read horizontally on the right side of an album. The reproduction images vary in colour and position because the photographs taken of the Wilbour Library of Egyptology albums were not taken in the same lighting conditions and are not laying flat like the albums from the Archive of Modern Conflict or Universite Laval. Each institution digitized the images (from the AMC and Université Laval), I photographed the Wilbour Library of Egyptology albums, and there are no images of the photographs from the British Library due to reproduction costs.

The notes section is where I describe any key differences between the prints at each institution and where I explain which institution each image comes from. This is where I illustrate if a print's orientation is different in the various albums. I use the term "laterally reversed", which indicates that when the negative was used to make the print, it was printed on the incorrect side of the negative, creating a reversed or flipped version of the intended view. While I cannot determine which view is laterally reversed and which view is correct, I note that there is a discrepancy in the different versions. Due to the fact that I do not have photographs from the British Library for reference, the notes on the British Library albums lack certain details compared to the other albums.

The measurements are arranged by height and width and have been measured in centimeters. The proper titles of the prints are from the page of contents provided by the master sets and the titles in square parentheses are the titles from the corresponding letterpress texts beside each image.

I have transcribed the text directly from the text in the albums. I have kept the spelling errors within the text and have not corrected them as it is a direct transcription. Terms and titles of sites may be misspelt, or may have changed over time, but it was my aim to show what was directly present in the text. 
The initials underneath each text are attributions indicating who wrote the work. J.D. represents James Douglas, M.D., J.D. JR. represents James Douglas Jr., and N.D. represents Naomi Douglas. Occasionally a woman named Mary Macdonald will write a text or an excerpt from her journals will be used in the texts. She is presently unidentified. 


\section{CONCORDANCE}

\section{EGYPT}

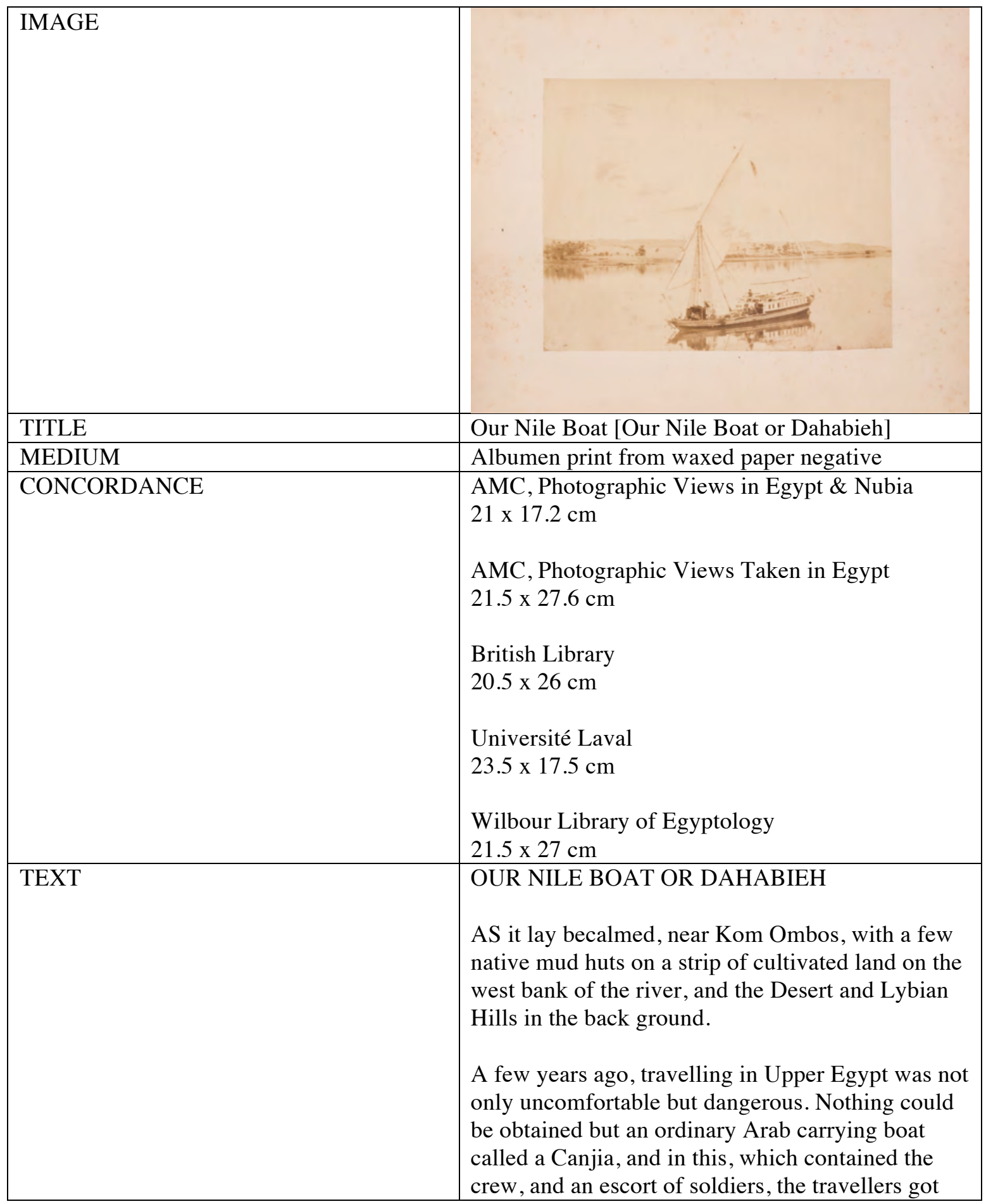




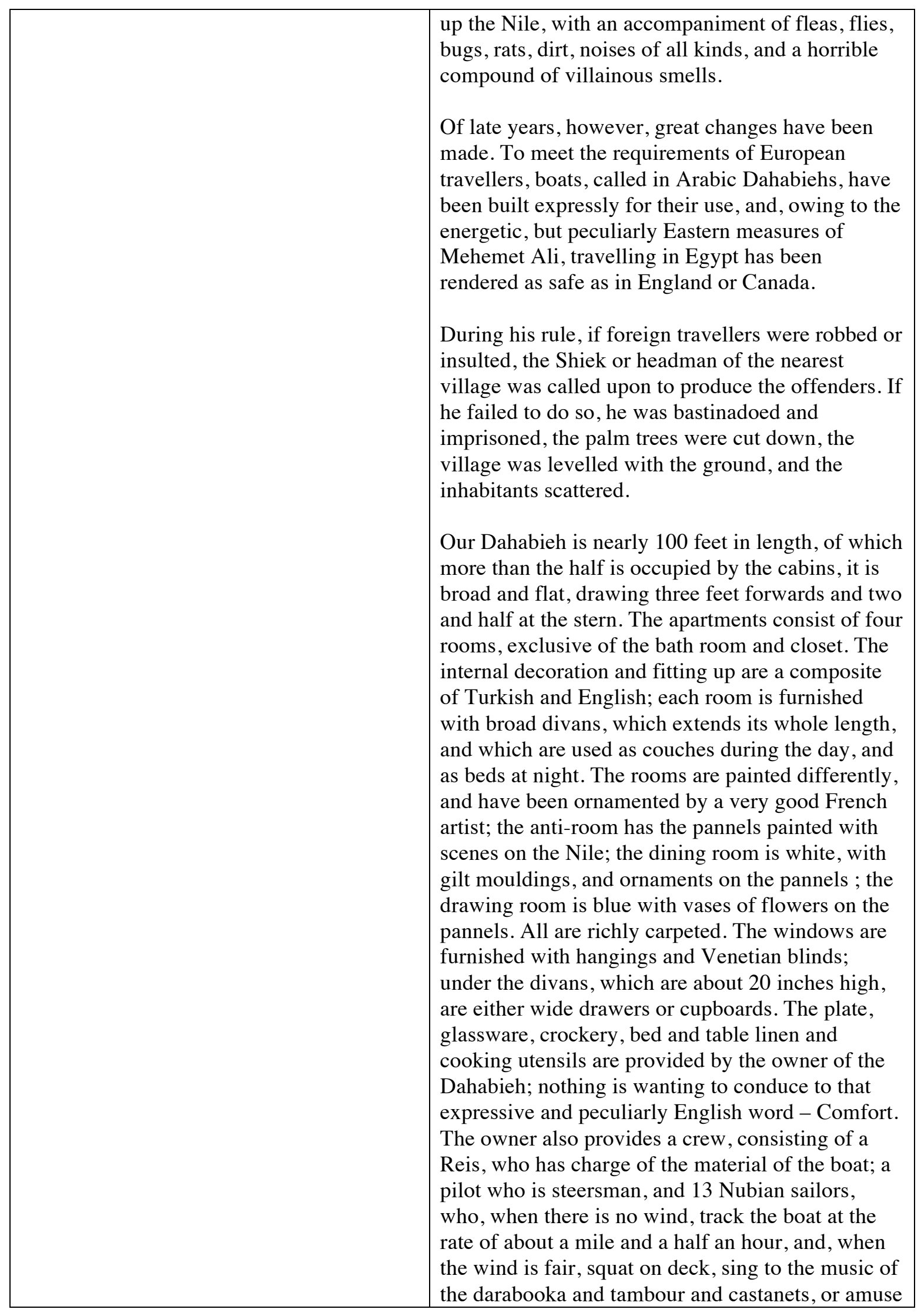




\begin{tabular}{|c|c|}
\hline & $\begin{array}{l}\text { themselves with imitations of the dances of the } \\
\text { Ghawazee girls. Our personal staff consists of a } \\
\text { dragoman, Achmet Salem, who provides for us, } \\
\text { who interprets for us, and who superintends all our } \\
\text { domestic and culinary comforts. He is always } \\
\text { extensively and expensively got up, and, when not } \\
\text { engaged in his business, upholds his dignity by } \\
\text { sitting in an arm chair on the lower deck, and (as is } \\
\text { seen in his stereoscopic likeness, smoking a long } \\
\text { and rich Turkish pipe. Mahmoud, the cook, is a } \\
\text { Nubian, very clean, very obliging, very punctual, } \\
\text { and quite an artist in his way. He is represented in } \\
\text { his kitchen, which is placed immediately in front } \\
\text { of the mast. Hallel, a waiter, also a Nubian, very } \\
\text { tall, very thin, very dignified and solemn, with a } \\
\text { strong disposition not to do any more than he can } \\
\text { well avoid; and, Ramadan, a smart lad, who assists } \\
\text { at table, cleans the shoes, carries the gun or } \\
\text { gamebag, and makes himself generally useful as } \\
\text { assistant photographer and lay figure, which last } \\
\text { function, as may be seen in the plate, he performs } \\
\text { very well, when assured, after repeated trials, that } \\
\text { the instrument would not go off. } \\
\text { Altogether, few homes are more comfortable, or } \\
\text { better furnished than a good Dahabieh. The table is } \\
\text { excellent, and is generally provided for in the } \\
\text { contract with the Dragoman. Breakfast at } 7 \text { A.M., } \\
\text { consists of café au lait, hot rolls, eggs, and at least } \\
\text { two made dishes. Lunch at } 12 \text {, consists of cold } \\
\text { meat, fresh and dried fruits, and coffee. Tea at } 8 \text {, } \\
\text { bread, butter, and preserves. Ham, bacon, tea, } \\
\text { butter, preserves, \&c., I have always provided in } \\
\text { Canada, as these are neither so good nor cheap in } \\
\text { Egypt. } \\
\text { Flour, rice, macaroni, and small stores of good } \\
\text { quality, are procurable in Alexandria. Mocha } \\
\text { coffee, of first brand, can be had cheap in Cairo. } \\
\text { Beef, mutton, fowls, fish, game, milk, and eggs are } \\
\text { abundant on the Nile. The beef is indifferent, and } \\
\text { leaves a doubt whether what you have been eating } \\
\text { pas of Ox, or Buffalo, or Camel. Wine can be } \\
\text { in Marseilles, Malta, or Alexandria. }\end{array}$ \\
\hline NOTES & $\begin{array}{l}\text { Image from AMC, Photographic Views Taken in } \\
\text { Egypt. The photographs from Université Laval and } \\
\text { AMC, Photographic Views in Egypt \& Nubia are }\end{array}$ \\
\hline
\end{tabular}




\begin{tabular}{|l|l|}
\hline & $\begin{array}{l}\text { smaller because they have been cropped for the } \\
\text { title page. }\end{array}$ \\
\hline
\end{tabular}

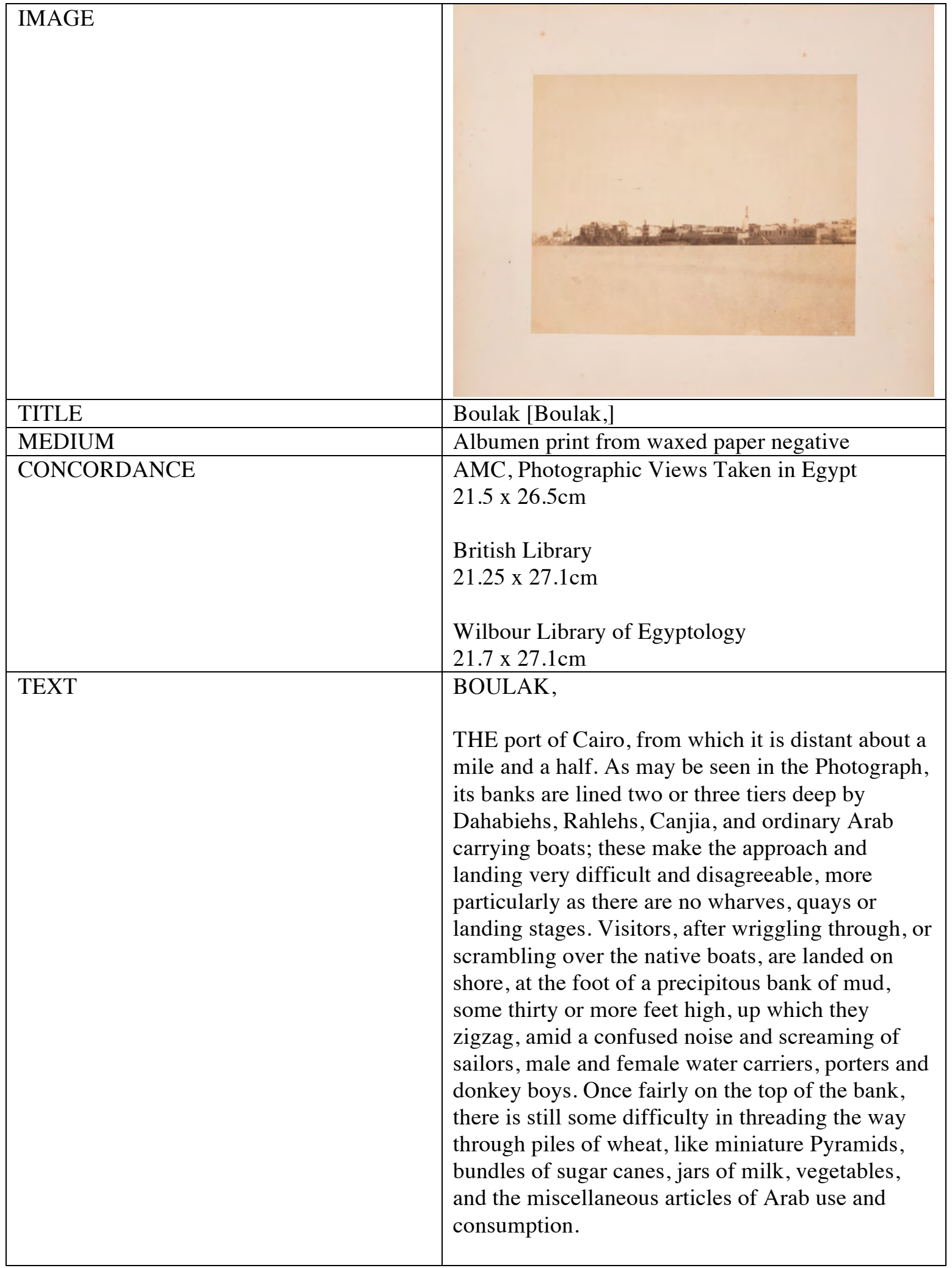




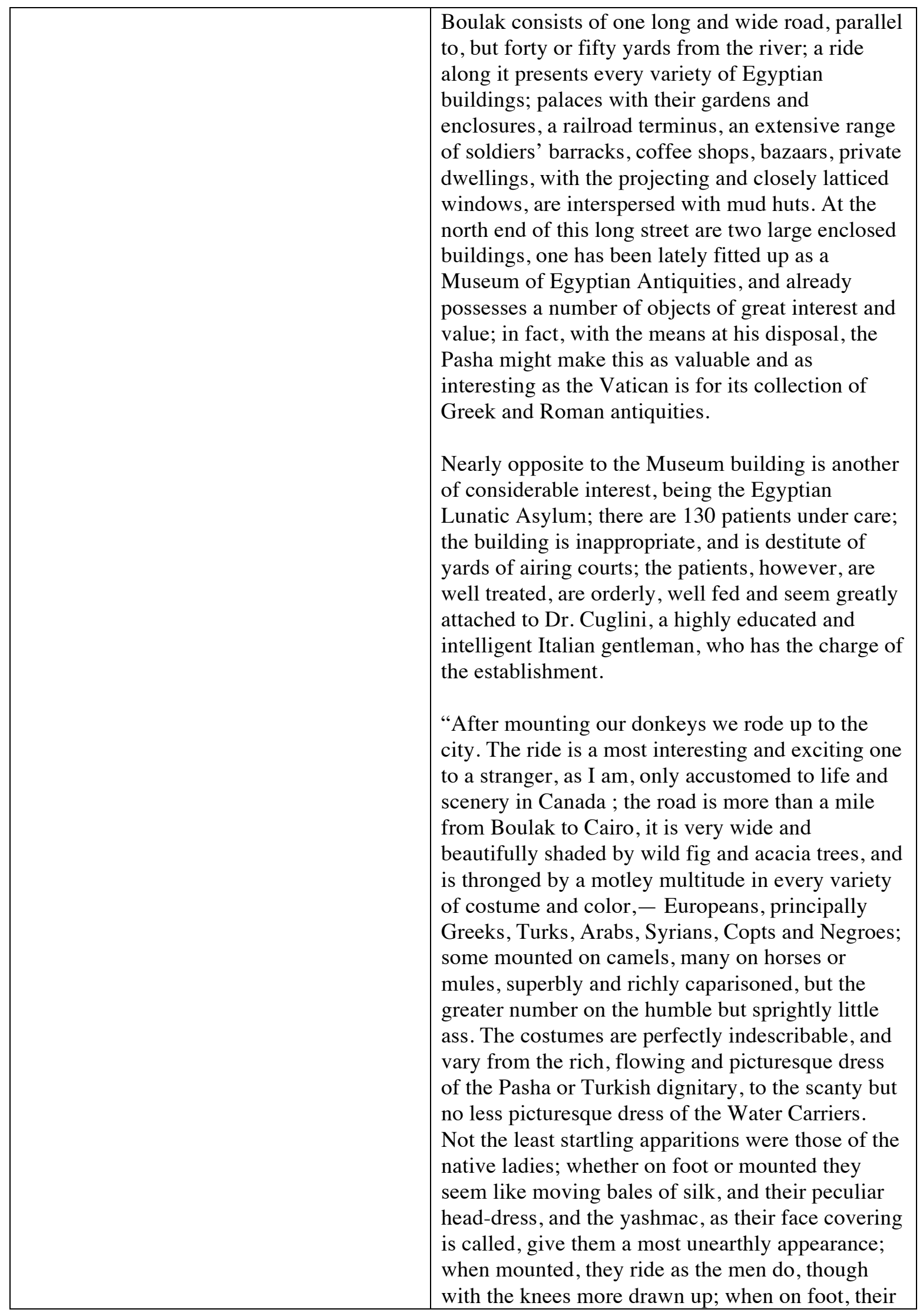




\begin{tabular}{|l|l|}
\hline & $\begin{array}{l}\text { walk is very peculiar and waddling, owing } \\
\text { probably to the use of the wide yellow slippers } \\
\text { which they all wear." * }\end{array}$ \\
{$\left[\begin{array}{l}* \text { From Miss MACDONALD'S Journal.] } \\
\text { J.D. }\end{array}\right.$} \\
\hline NOTES & $\begin{array}{l}\text { Image from AMC, Photographic Views Taken in } \\
\text { Egypt. }\end{array}$ \\
\hline
\end{tabular}

\begin{tabular}{|c|c|}
\hline IMAGE & \\
\hline TITLE & Bedreyshayn [Bedreyshayn] \\
\hline MEDIUM & Albumen print from waxed paper negative \\
\hline CONCORDANCE & $\begin{array}{l}\text { British Library } \\
21.25 \times 27 \mathrm{~cm} \\
\text { Wilbour Library of Egyptology } \\
21.8 \times 27 \mathrm{~cm}\end{array}$ \\
\hline TEXT & $\begin{array}{l}\text { BEDRESHAYN } \\
\text { WAS the Port or Landing Place on the Nile of the } \\
\text { ancient City of Memphis. It is now, however, an } \\
\text { ordinary Arab village, in no ways distinguished } \\
\text { from ordinary Arab villages, except, perhaps, by } \\
\text { the extent and beauty of the groves of Date Palm } \\
\text { Trees, among which it lies embosomed. } \\
\text { Of Memphis, which for some thousand years, was } \\
\text { the Capital of Egypt, and which successive } \\
\text { dynasties of Pharaohs vied in adorning, nothing } \\
\text { now remains but extensive mounds of earth which } \\
\text { cover sculptured stones, fragments of Statues, } \\
\text { bricks and pottery. Here and there, a fallen Statue } \\
\text { or pillar, or the remains of a gateway of one of the } \\
\text { old Temples remains uncovered A colossal Statue } \\
\text { of Rameses, which is remarkable for its exquisite } \\
\text { finish and beauty, lies partly uncovered at the }\end{array}$ \\
\hline
\end{tabular}




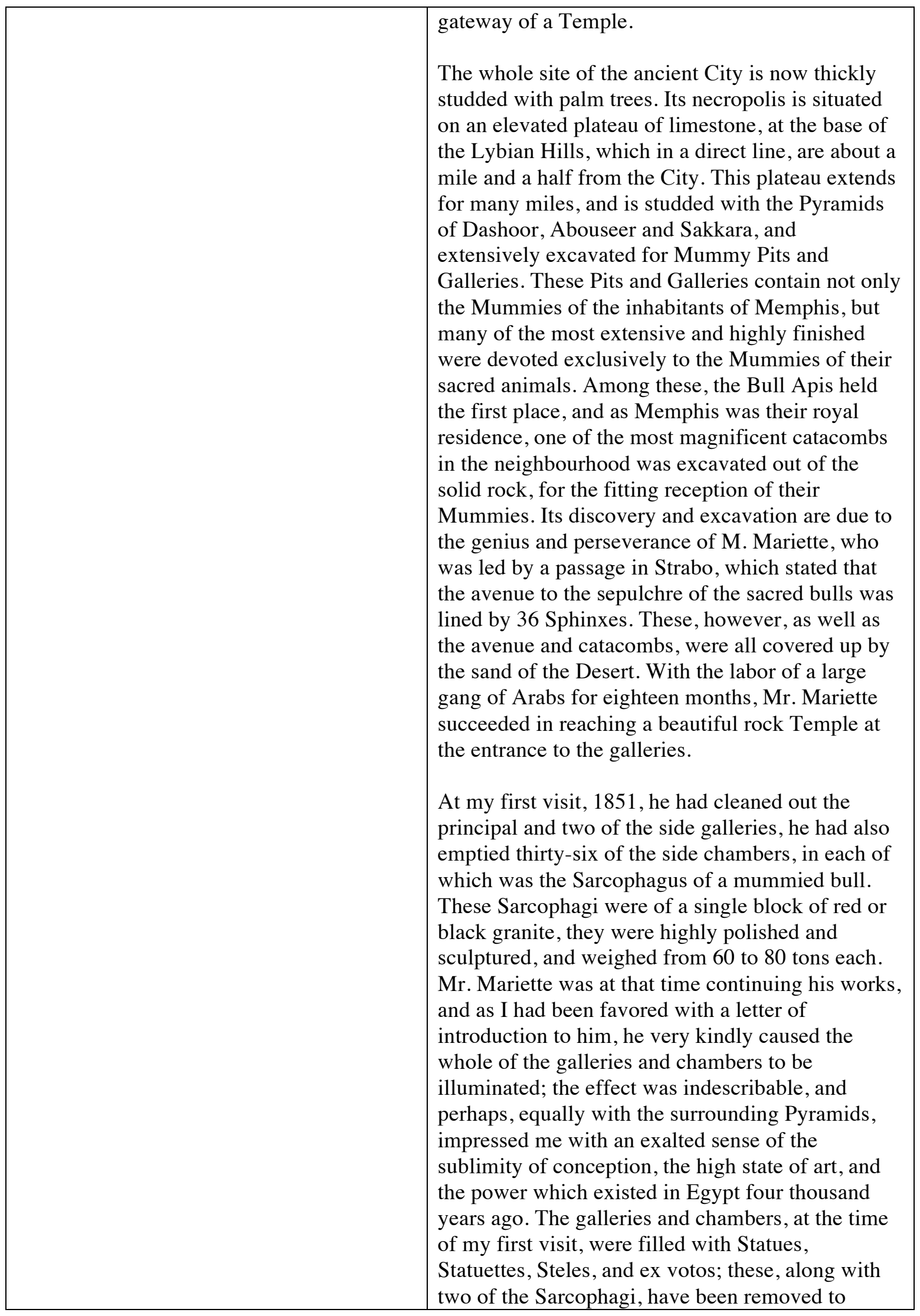




\begin{tabular}{|l|l|}
\hline & $\begin{array}{l}\text { Europe by Mr. Mariette. The works are now } \\
\text { abandoned, and in a very few years, the sand of the } \\
\text { Desert will again obliterate all traces of this } \\
\text { magnificent sepulchre. } \\
\text { J.D. }\end{array}$ \\
\hline NOTES & $\begin{array}{l}\text { Image from Brooklyn Museum Libraries. Wilbour } \\
\text { Library of Egyptology, Special Collections. }\end{array}$ \\
\hline
\end{tabular}

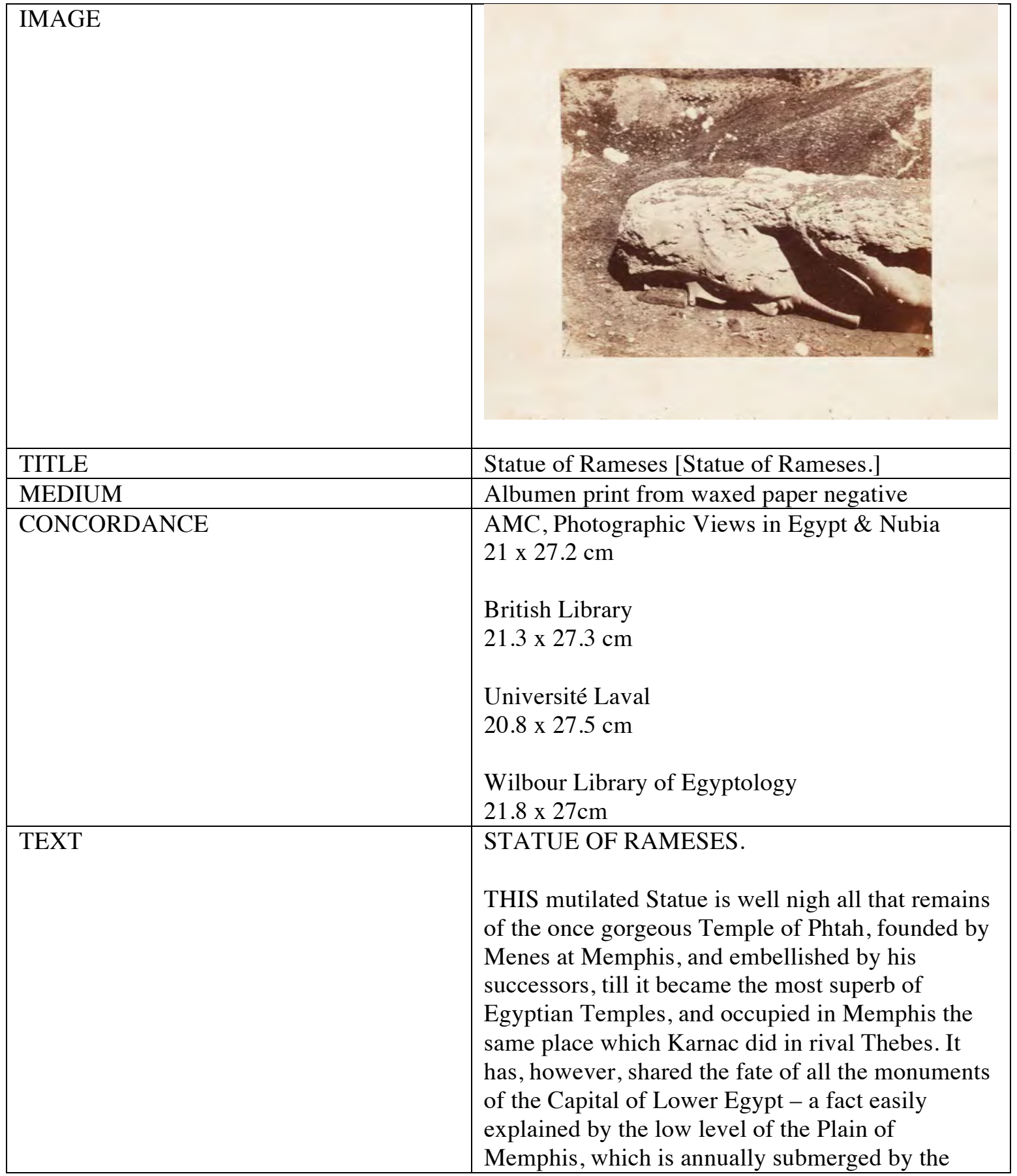




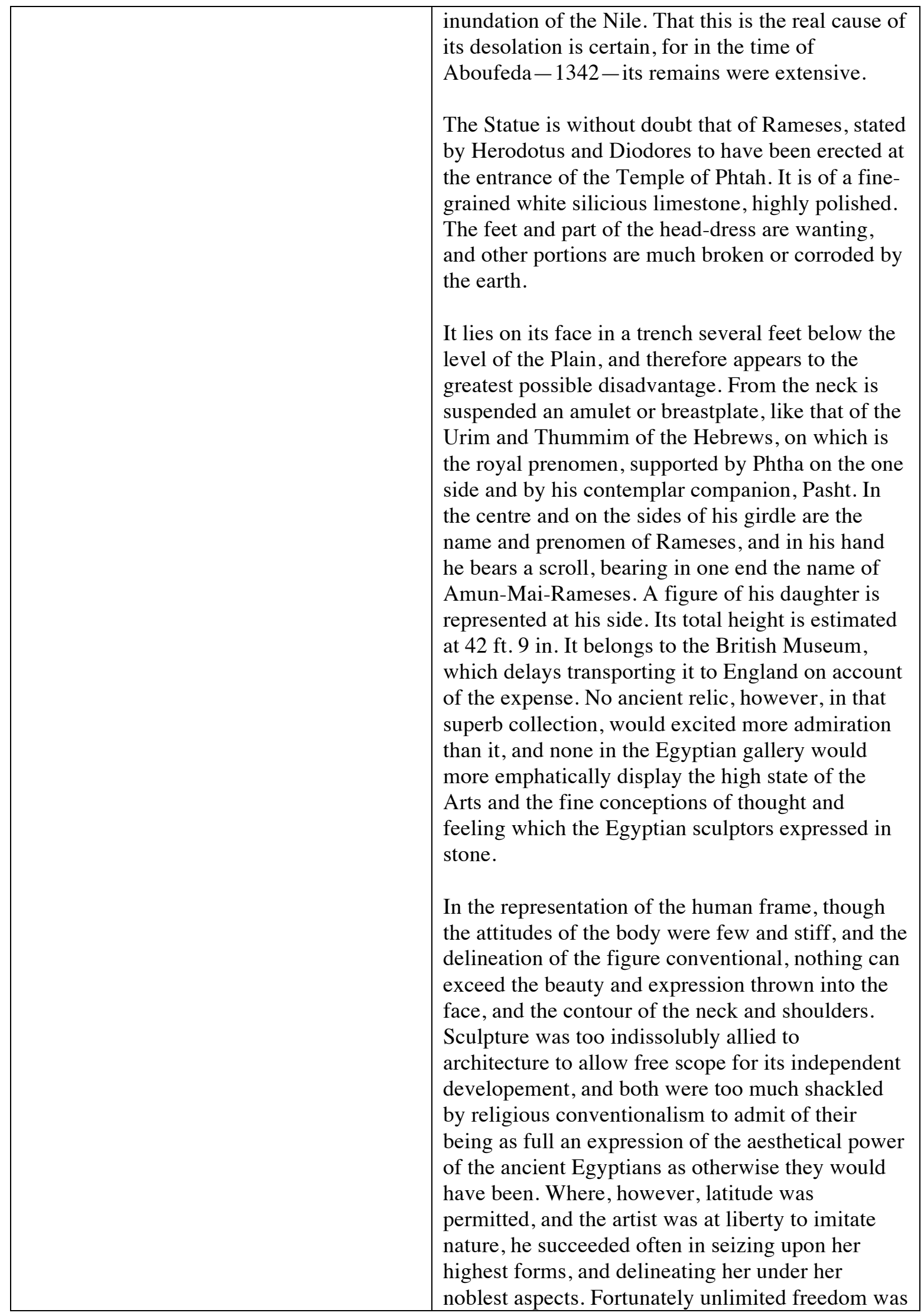




\begin{tabular}{|l|l|}
\hline & $\begin{array}{l}\text { used in the portraiture of the human face, and to it } \\
\text { therefore we must look in judging of the real } \\
\text { capabilities of Egyptian art. It is true that the range } \\
\text { of subjects even here is limited. Few attempts were } \\
\text { made to express the passions, probably because } \\
\text { calmness was thought to be the only state worthy } \\
\text { of royalty, and it is in the portraiture of their kings } \\
\text { that greatest care was taken; yet the admirable } \\
\text { manner in which they have shed this calmness, } \\
\text { combined with a consciousness of dignity and } \\
\text { power, over not only the countenance, but the } \\
\text { whole figure, in their Statues and bas-reliefs, } \\
\text { shews how capable they were of producing any } \\
\text { other effect had it been required. In the tombs, for } \\
\text { instance, the human face occasionally bears an } \\
\text { expression of deep sorrow and piteous sadness, as } \\
\text { profound as it is possible to conceive. }\end{array}$ \\
\hline J.D., JR. \\
\hline NOTES & $\begin{array}{l}\text { Image from AMC, Photographic Views in Egypt \& } \\
\text { Nubia. }\end{array}$ \\
\hline
\end{tabular}

\begin{tabular}{|l|l|}
\hline IMAGE & \\
& \\
& \\
& \\
& \\
\hline TITLE & \\
\hline MEDIUM & Pyramid of Sakhara [Pyramid of Sakhara.] \\
\hline CONCORDANCE & Albumen print from waxed paper negative \\
\hline & AMC, Photographic Views in Egypt \& Nubia \\
& $20.7 \times 27.4 \mathrm{~cm}$ \\
& British Library \\
& $21.3 \times 27.7 \mathrm{~cm}$ \\
& Université Laval \\
& $20.3 \times 27.1 \mathrm{~cm}$ \\
& Wilbour Library of Egyptology \\
& $21.9 \times 27 \mathrm{~cm}$ \\
\hline
\end{tabular}




\begin{tabular}{|c|c|}
\hline TEXT & $\begin{array}{l}\text { PYRAMID OF SAKHARA. } \\
\text { THE Sakhara group consists of } 9 \text { Pyramids, of } \\
\text { which this is by far the largest and most important. } \\
\text { Two have been opened, but no royal names found } \\
\text { among the hierogylphical fragments which strew } \\
\text { their chambers. The standard name however of the } \\
\text { Kings of the } 3^{\text {rd }} \text { and } 4^{\text {th }} \text { dynasties (a family } \\
\text { appellation used on religious occasions) has been } \\
\text { found, which approximately decides the date, and } \\
\text { assigns them an antiquity equal at least to that of } \\
\text { the celebrated Pyramids of Ghizeh. } \\
\text { Contrary to the custom of the New Empire, few } \\
\text { hieroglyphs occur either in the walls of the } \\
\text { passages through which the royal mummy } \\
\text { descended to its rocky tomb, or on the } \\
\text { sarcophagus. Everything was massive, gloomy and } \\
\text { suggestive of death. With this the intellectual } \\
\text { activity implied even in writing, and much more } \\
\text { the liveliness of pictorial illustration, were felt to } \\
\text { be inconsistent. Much was changed in this respect } \\
\text { after the Hykos period, - when the Tombs of the } \\
\text { Kings appear among the most important } \\
\text { monuments both in their historical and } \\
\text { mythological bearing, and in the light they throw } \\
\text { on the manners and customs of the people. } \\
\text { J.D. JR. } \\
\text { The } 3 \text { rd Pyramid of Sakhara, which the photograph } \\
\text { represents as seen from the S.Q., though by no } \\
\text { means imposing externally, is inferior to none, not } \\
\text { even to the Pyramids of Ghizeh, in the magnitude } \\
\text { and perfect workmanship of its interior } \\
\text { construction and arrangement. From some freak of } \\
\text { the builder it is less symmetrical than others, the } \\
\text { base not being square. It is moreover distinguished } \\
\text { by two other peculiarities; its sides are not sloping, } \\
\text { but built in six steps or degrees, and they do not } \\
\text { face the cardinal points, which, probably for } \\
\text { astronomical purposes, the Pyramid builders ; but } \\
\text { was applied with unerring accuracy to none but the } \\
\text { great Pyramid of Ghizeh which is mathematically } \\
\text { perhaps the most perfect building in existence. } \\
\text { thambers would be }\end{array}$ \\
\hline
\end{tabular}




\begin{tabular}{|l|l|}
\hline NOTES & $\begin{array}{l}\text { Image from AMC, Photographic Views in Egypt \& } \\
\text { Nubia. }\end{array}$ \\
\hline
\end{tabular}

\begin{tabular}{|c|c|}
\hline IMAGE & \\
\hline TITLE & Pyramid of Dashoor [The Stone Pyramid of \\
\hline MEDIUM & Albumen print from waxed paper negative \\
\hline CONCORDANCE & $\begin{array}{l}\text { AMC, Photographic Views Taken in Egypt } \\
21.5 \times 28 \mathrm{~cm} \\
\text { British Library } \\
21.3 \times 27.9 \mathrm{~cm} \\
\text { Université Laval } \\
21 \times 27.3 \mathrm{~cm} \\
\text { Wilbour Library of Egyptology } \\
21.5 \times 26.5 \mathrm{~cm}\end{array}$ \\
\hline TEXT & $\begin{array}{l}\text { THE STONE PYRAMID OF DASHOOR. } \\
\text { THE whole of the Old Egyptian Empire may be } \\
\text { called the Pyramid Period. Sixty of these structures } \\
\text { are said to exist, though twenty-eight or twenty- } \\
\text { nine only are of large size. These may be divided } \\
\text { into three groups - a northern, southern and } \\
\text { middle. The northern comprises the Pyramid of } \\
\text { About Roash and those of Ghizeh; the southern } \\
\text { those of the Fayoum and several farther south; and } \\
\text { the middle the various groups of Pyramids which } \\
\text { crown the Libyan Hills above Memphis. } \\
\text { They are now, with one consent, admitted to have } \\
\text { been built over the rocky tombs of royal } \\
\text { personages. The larger probably decide the } \\
\text { existence of as many Kings, though who they were } \\
\text { cannot in most cases be determined. Three have, }\end{array}$ \\
\hline
\end{tabular}




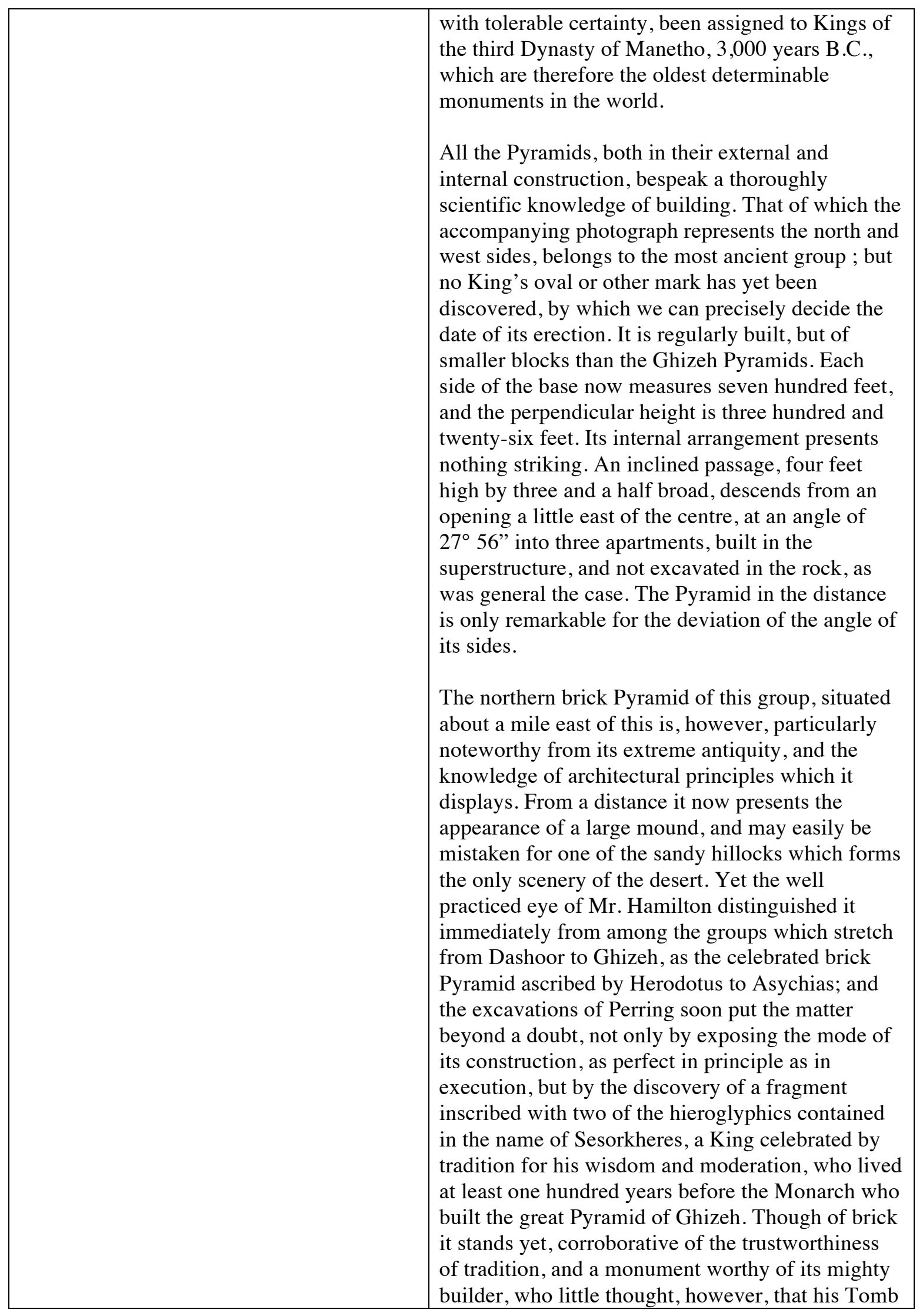




\begin{tabular}{|l|l|}
\hline & $\begin{array}{l}\text { would be viewed with reverence as the oldest } \\
\text { known work of man on the face of the earth. }\end{array}$ \\
$\begin{array}{ll}\text { The foundation was sand, confined by a platform } \\
\text { of stone, and the Pyramid itself was built of bricks, } \\
\text { some made of alluvial clay, others of sandy loam } \\
\text { with more or less straw, laid in courses chiefly } \\
\text { from north to south. This was cased with stone, } \\
\text { and to the north was attached a Portico or } \\
\text { Hypæthral Temple, corresponding to those found } \\
\text { in similar position in Ethiopia. Of the stone-work } \\
\text { all but vestiges have disappeared; the more } \\
\text { perishable material alone remains, an unequivocal } \\
\text { witness of advanced civilization. }\end{array}$ \\
\begin{tabular}{ll} 
J.D., JR. \\
\hline NOTES
\end{tabular} & $\begin{array}{l}\text { Image from AMC, Photographic Views Taken in } \\
\text { Egypt. The AMC, Photographic Views Taken in } \\
\text { Egypt version has the same image orientation as } \\
\text { Université Laval. The orientation of the image is } \\
\text { laterally reversed in the Wilbour Library of } \\
\text { Egyptology. }\end{array}$ \\
\hline
\end{tabular}

\begin{tabular}{|c|c|}
\hline IMAGE & \\
\hline TITLE & Minieh [Minieh,] \\
\hline MEDIUM & Albumen print from waxed paper negative \\
\hline CONCORDANCE & $\begin{array}{l}\text { British Library } \\
21.2 \times 27.6 \mathrm{~cm} \\
\text { Wilbour Library of Egyptology } \\
21.4 \times 26.8 \mathrm{~cm}\end{array}$ \\
\hline TEXT & $\begin{array}{l}\text { MINIEH, } \\
\text { AN Arab village on the west bank of the river, } \\
\text { about } 160 \text { miles above Cairo, is chiefly remarkable }\end{array}$ \\
\hline
\end{tabular}




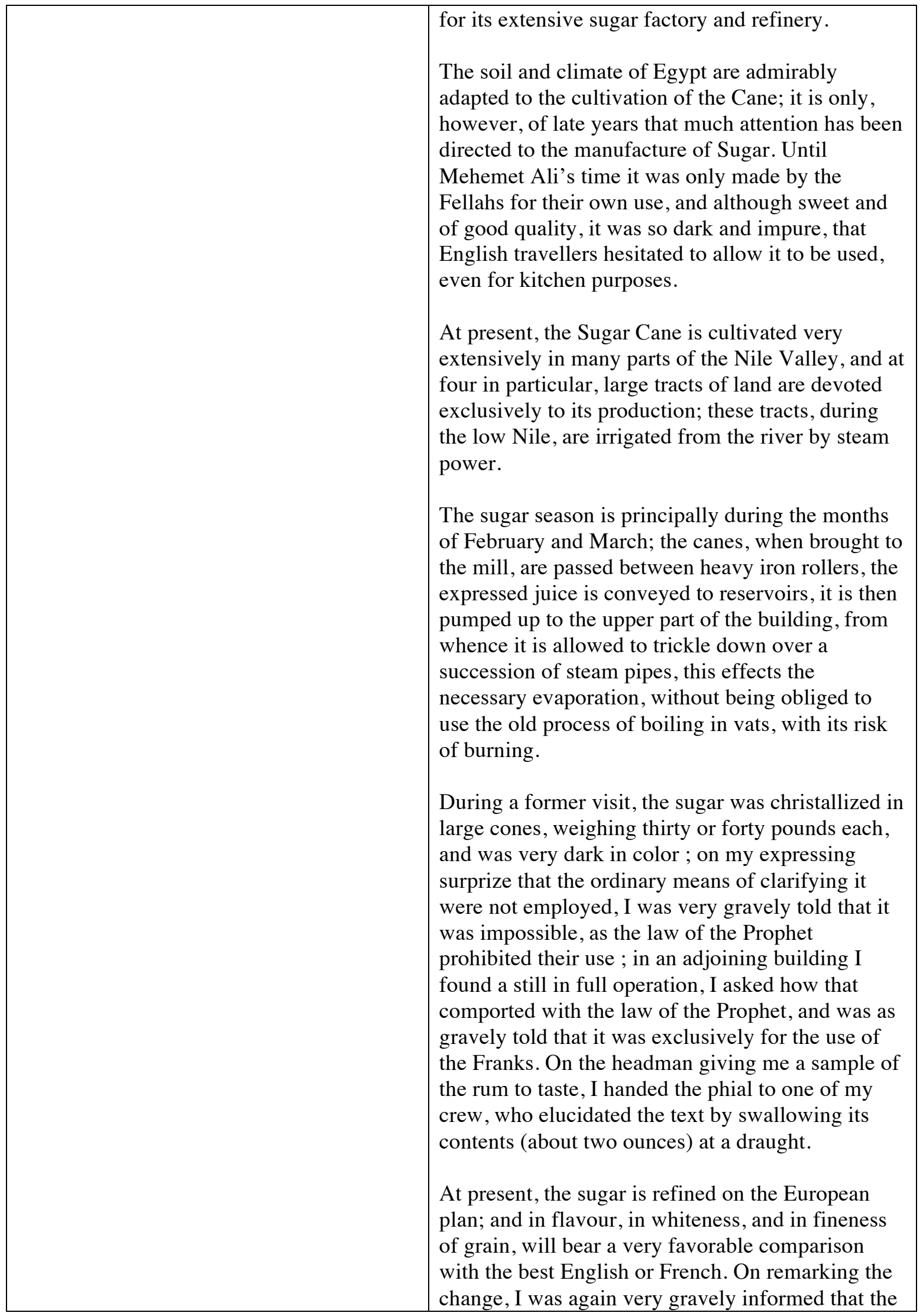




\begin{tabular}{|l|l|}
\hline & $\begin{array}{l}\text { sugar was exclusively for exportation. On } \\
\text { subsequent inquiry, I could not find, however, that } \\
\text { any was exported, on the contrary, that a } \\
\text { considerable quantity was imported from France. } \\
\text { Minieh, I believe, is yet the only sugar refinery in } \\
\text { the Valley of the Nile. The sugars made at two } \\
\text { other factories, Erment and Farshoot, are sent to } \\
\text { Minieh to be refined. } \\
\text { A great change is being effected in the habits and } \\
\text { religious feelings of the Arabs. During my first } \\
\text { visit to the Cataracts, out of a crew of fifteen, all } \\
\text { regularly prayed, and only two would taste wine, } \\
\text { and not then unless unobserved. During my last } \\
\text { visit, out of a crew of thirteen, only two prayed, } \\
\text { and only two or three refused to taste wine. During } \\
\text { this trip, all drink any given quantity, and none } \\
\text { pray; at the commencement of the voyage, one } \\
\text { elderly man attempted it, but got so hooted and } \\
\text { laughed at, that I never saw him again in the act. }\end{array}$ \\
\hline NOTES & $\begin{array}{l}\text { Image from Brooklyn Museum Libraries. Wilbour } \\
\text { Library of Egyptology, Special Collections. }\end{array}$ \\
\hline J.D.
\end{tabular}

\begin{tabular}{|l|l|}
\hline IMAGE & \\
& \\
& \\
\hline TITLE & Tombs of Beni-Hassan [Tombs of Beni-Hassan] \\
\hline MEDIUM & Albumen print from waxed paper negative \\
\hline CONCORDANCE & $\begin{array}{l}\text { AMC, Photographic Views in Egypt \& Nubia } \\
21.2 \times 27.4 \mathrm{~cm}\end{array}$ \\
& British Library \\
& $21.4 \mathrm{x} 27.3 \mathrm{~cm}$ \\
\hline
\end{tabular}




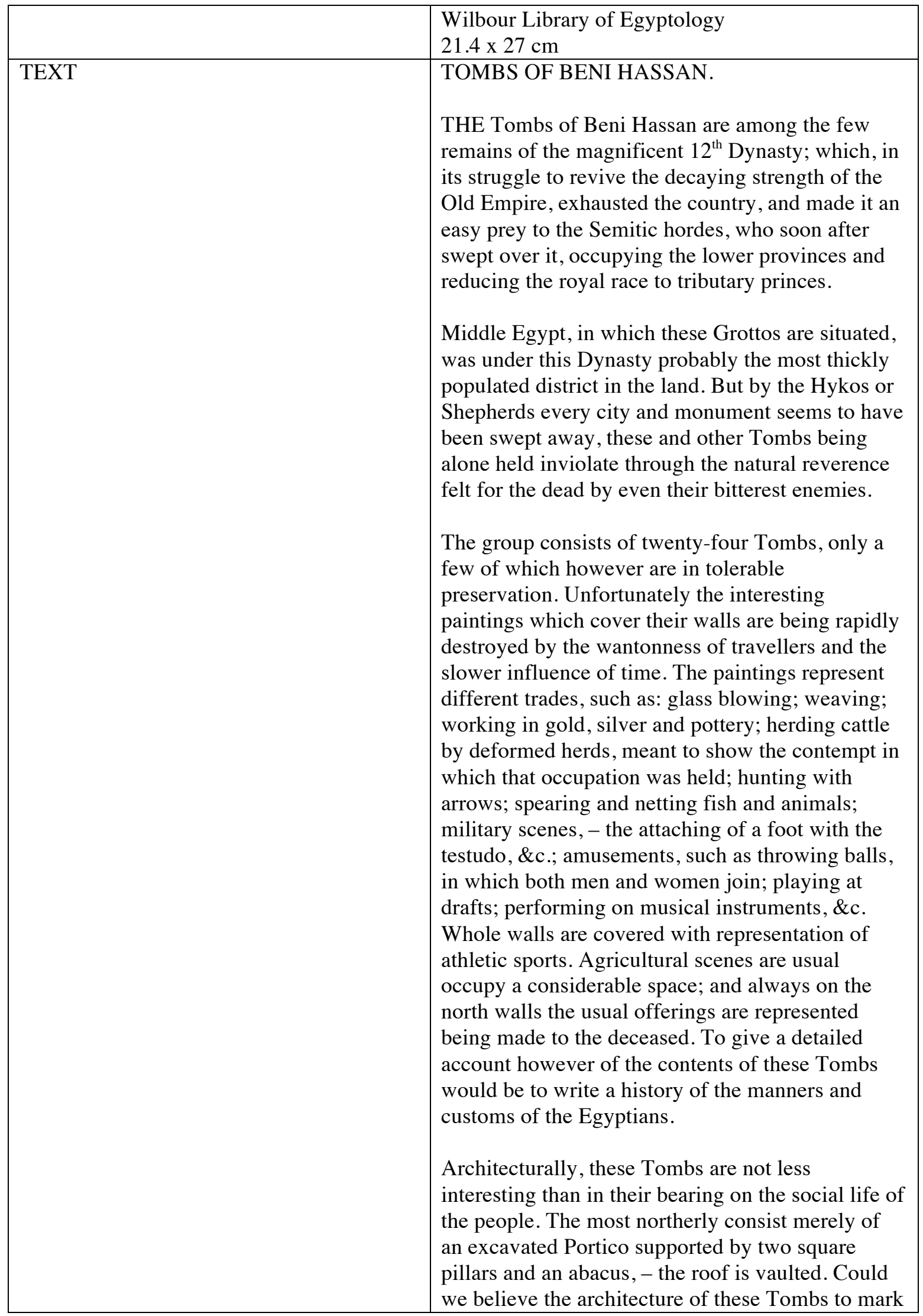




\begin{tabular}{|c|c|}
\hline & $\begin{array}{l}\text { the gradual development of the art, we would } \\
\text { naturally consider this to be the first, as being the } \\
\text { most simple order. A single step would lead to the } \\
\text { use of the octagonal column, and then to that with } \\
\text { sixteen and even thirty-two facets. By a curious } \\
\text { coincidence (for we can regard it in no other light) } \\
\text { the three following Tombs afford examples of } \\
\text { these varieties. The Portico of the first is supported } \\
\text { by two octagonal columns, but the roof of the } \\
\text { Tomb by four polygonal pillars with sixteen facets. } \\
\text { The facets are slightly grooved. An architrave runs } \\
\text { from pillar to pillar; and the roof, which is cut in } \\
\text { the form of a vault, is tastefully ornamented with } \\
\text { checquered devices. The pillars are so arranged as } \\
\text { to form a centre and two lateral aisles. The third } \\
\text { Tomb and others of the northern group, with a } \\
\text { single Tomb in the southern, exhibit the same } \\
\text { characteristics. } \\
\text { But in the large Grottos further south apparently a } \\
\text { later style of architecture was employed. No } \\
\text { Portico forms the approach: but the roof of the } \\
\text { Tomb is supported by columns formed of four } \\
\text { stalks of the lotus reed bound together beneath the } \\
\text { buds, which compose the capitals. The architrave, } \\
\text { which crosses the Tomb breadthways, is slightly } \\
\text { arched and rests at either end on a narrow pilaster. } \\
\text { A more natural order of development than that } \\
\text { which these Tombs illustrate cannot be conceived; } \\
\text { and had they been excavated at long intervals from } \\
\text { one another we should have been tempted to trace } \\
\text { it in them: but as all were finished during two } \\
\text { reigns, and as the employment of the arch and the } \\
\text { abacus, in even the simplest, betokens a highly } \\
\text { advanced state of the art, we are unable to believe } \\
\text { that they point to the earliest architectural efforts. } \\
\text { Nothing can be more elegant and chaste than both } \\
\text { their decoration and arrangement; and did no other } \\
\text { evidence exist we should be justified in concluding } \\
\text { from them alone that the more gorgeous and turgid } \\
\text { degen in the civilisation of the nation. }\end{array}$ \\
\hline NOTES & $\begin{array}{l}\text { Image from AMC, Photographic Views in Egypt \& } \\
\text { Nubia. }\end{array}$ \\
\hline
\end{tabular}




\begin{tabular}{|c|c|}
\hline IMAGE & \\
\hline TITLE & Osioot [Osioot] \\
\hline MEDIUM & Albumen print from waxed paper negative \\
\hline CONCORDANCE & $\begin{array}{l}\text { British Library } \\
20.2 \times 25.6 \mathrm{~cm} \\
\text { Wilbour Library of Egyptology } \\
21.6 \times 27 \mathrm{~cm}\end{array}$ \\
\hline TEXT & $\begin{array}{l}\text { OSIOOT. } \\
\text { [From the unpublished Journal of Miss } \\
\text { MACDONALD.] } \\
\text { WE stopped at Osioot for the purpose of enabling } \\
\text { the sailors to bake bread, which, with the onions } \\
\text { and other vegetables they steal from the banks, } \\
\text { seems to be their principal food. } \\
\text { We rode to the mummy pits, which are excavated } \\
\text { in the limestone hills about a mile behind the city. } \\
\text { These grottos, tombs and pits, are very numerous } \\
\text { and extensive, and have been used from the time of } \\
\text { the old monarchy to the later Roman period. The } \\
\text { Wolf was held sacred here, and many of the pits } \\
\text { were filled with their mummies. } \\
\text { The hall of the principal Tomb which we visited } \\
\text { had been used as a Temple, its walls were covered } \\
\text { with sculptures and inscriptions, and the roof was } \\
\text { supported by pillars, hewn out of the solid rock; } \\
\text { but the sculptures and paintings have been defaced, } \\
\text { the pillars are being broken down, and, with the } \\
\text { portals of the Temple, and parts of the walls, have } \\
\text { been taken away to be burnt for lime. } \\
\text { From the entrance hall, passages lead to galleries }\end{array}$ \\
\hline
\end{tabular}




\begin{tabular}{|l|l|}
\hline & $\begin{array}{l}\text { and chambers in which the mummies were } \\
\text { deposited; in the chambers, pits are occasionally } \\
\text { sunk, and from these again other galleries and } \\
\text { chambers lead off. In front of this and of the other } \\
\text { tombs which we visited, were piles upon pules of } \\
\text { portions of mummies of men and wolves, mummy } \\
\text { cloth of different textures, and broken jars. I picked } \\
\text { up and saved some fine linen, but could find } \\
\text { nothing else worth taking away. The Arabs had } \\
\text { used and still use the mummies for the purpose of } \\
\text { burning lime. }\end{array}$ \\
& $\begin{array}{l}\text { We then strolled through the city and its Bazaars. } \\
\text { Osioot is the capital of Upper Egypt, and contains } \\
20,000 \text { inhabitants. The Bazaars are extensive and } \\
\text { well supplied, but they seemed particularly narrow } \\
\text { and crowded, and reminded me very strongly of } \\
\text { the descriptions in the Arabian night } \\
\text { entertainments. While in the Bazaar, I was much } \\
\text { alarmed by some of the howling Derwishes, they } \\
\text { were a frightful, dirty, and disgusting looking set, } \\
\text { my uncle was obliged to give them some money to } \\
\text { get rid of them. }\end{array}$ \\
\hline NOTES & $\begin{array}{l}\text { Image from Brooklyn Museum Libraries. Wilbour } \\
\text { Library of Egyptology, Special Collections. }\end{array}$ \\
\hline
\end{tabular}

\begin{tabular}{|l|l|}
\hline IMAGE & \\
& \\
& \\
& \\
\hline TITLE & \\
\hline MEDIUM & Osioot- Moslem Cemetery [Tombs Near Osioot.] \\
\hline CONCORDANCE & Albumen print from waxed paper negative \\
\hline & $\begin{array}{l}\text { AMC, Photographic Views Taken in Egypt } \\
\text { British Library }\end{array}$ \\
& $21.4 \mathrm{x} 27.3 \mathrm{~cm}$ \\
& Université Laval \\
\hline
\end{tabular}




\begin{tabular}{|c|c|}
\hline & $\begin{array}{l}20.9 \times 27 \\
\text { Wilbour Library of Egyptology } \\
22 \times 27 \mathrm{~cm}\end{array}$ \\
\hline TEXT & $\begin{array}{l}\text { TOMBS NEAR OSIOOT. } \\
\text { THIS curious scene is a Moslem Cemetery; where } \\
\text { almost every Tomb is covered by a dome and } \\
\text { surrounded by an enclosure, additions commonly } \\
\text { made only to those of saints and personages of } \\
\text { high rank. } \\
\text { Stretching for two or three miles along the foot of } \\
\text { the rugged hills, and contrasting in colour so } \\
\text { strongly with the deep green of the date groves } \\
\text { which border them on the other side, their } \\
\text { appearance is both brilliant and beautiful. } \\
\text { Internally the Tomb is as simple as the Mosque. A } \\
\text { mound somewhat larger than one of our own } \\
\text { graves, is constructed of stone over a spacious } \\
\text { vault. At each end of the mound is an upright; that } \\
\text { at the head covered by a turban, if the occupant be } \\
\text { a male, but if a female, by a fez. There is also } \\
\text { beneath it a tablet with the inscription. } \\
\text { The vault is general large enough for several } \\
\text { bodies. The face of the corpse, when in it, is } \\
\text { uncovered and turned toward Mecca; a little earth } \\
\text { is sprinkled over the body; but great care is taken } \\
\text { that nothing heavy rest upon the breast. } \\
\text { The hills from which the best view of them is } \\
\text { obtained, is likewise a grand Cemetery, perforated } \\
\text { with catacombs, which once contained the } \\
\text { mummies of human beings and wolves, that animal } \\
\text { being held in such peculiar reverence here, as to } \\
\text { give its name to the ancient city, Lycopolis. } \\
\text { The animal worship of ancient Egypt, is one of the } \\
\text { worst features of its religion. Almost every bird } \\
\text { and beast, and even some fish were held sacred, } \\
\text { either throughout the whole country or at some } \\
\text { special place. In the description of Bedresheyn is } \\
\text { an account of the extensive and magnificent } \\
\text { galleries which contained the mummies of the bull } \\
\text { Apis. None else in Egypt are as gorgeous, but } \\
\text { many are as curious. The natural grottos at } \\
\text { Moabdeh, } 25 \text { miles below Osioot, in which is the } \\
\text { largest deposit of mummified crocodiles, are }\end{array}$ \\
\hline
\end{tabular}




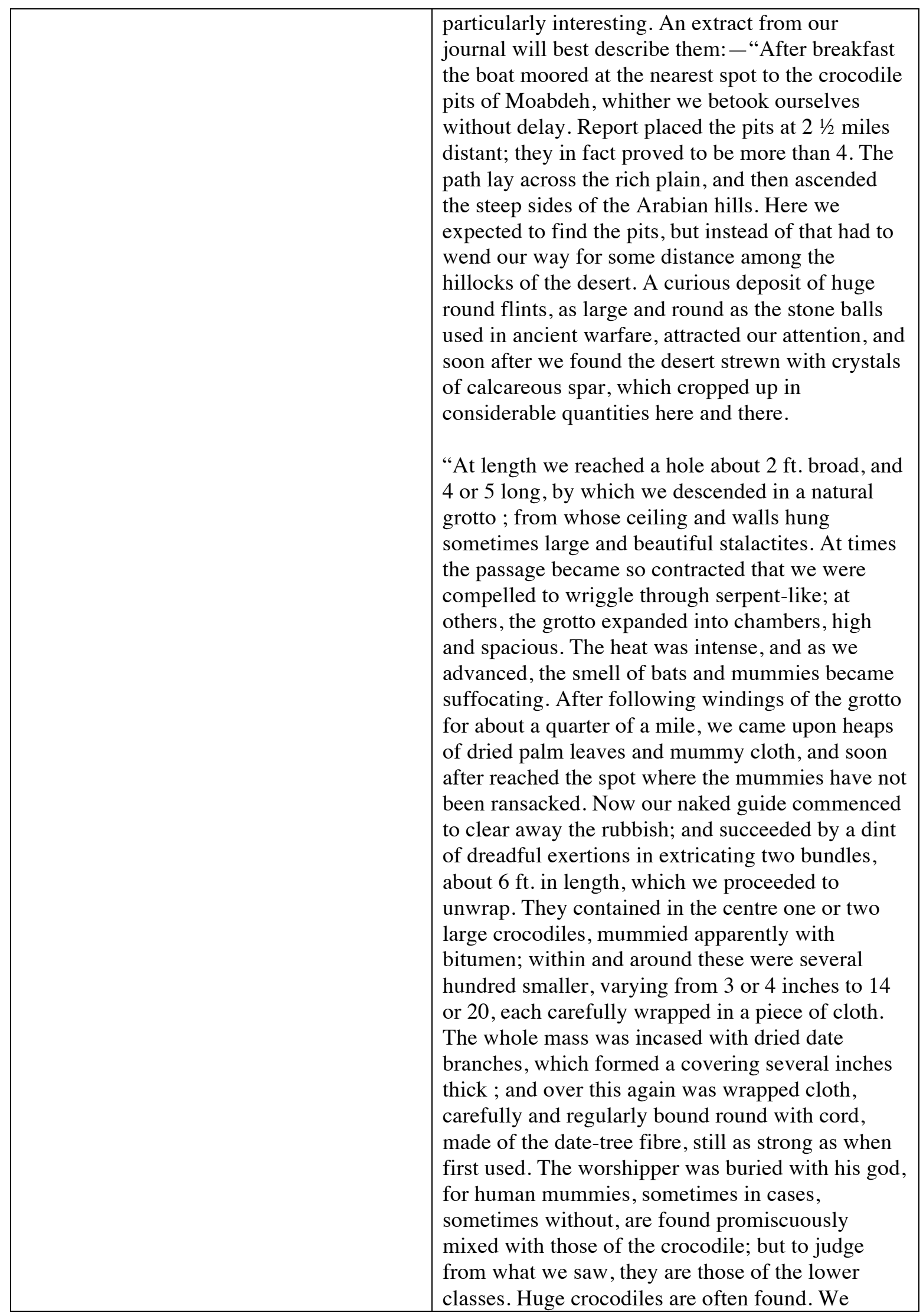




\begin{tabular}{|l|l|}
\hline & $\begin{array}{l}\text { measure one } 10 \mathrm{ft} . \text { long, but parts of others much } \\
\text { larger were lying about." } \\
\text { J.D., JR. }\end{array}$ \\
\hline NOTES & $\begin{array}{l}\text { Image from AMC, Photographic Views Taken in } \\
\text { Egypt. }\end{array}$ \\
\hline
\end{tabular}

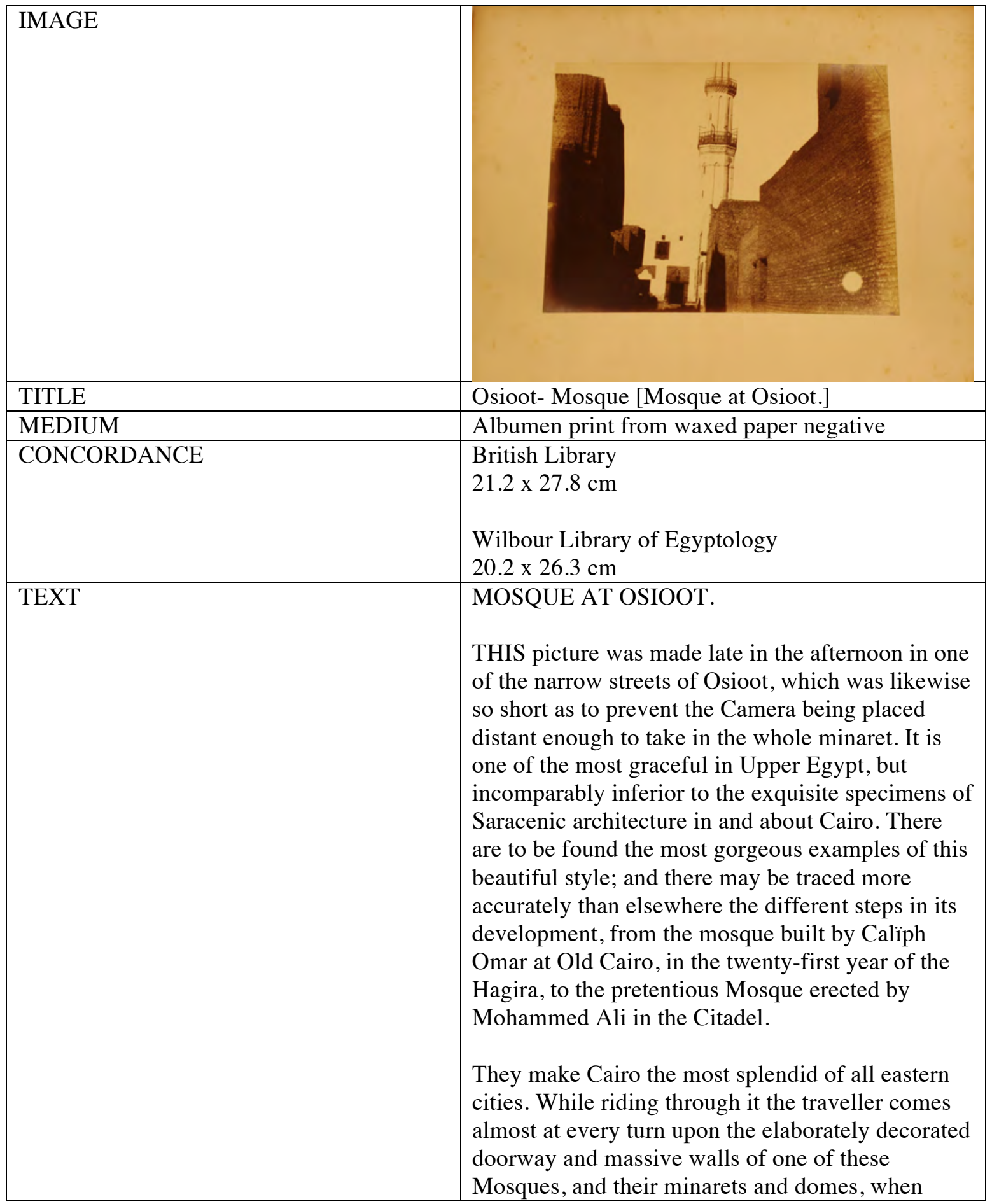




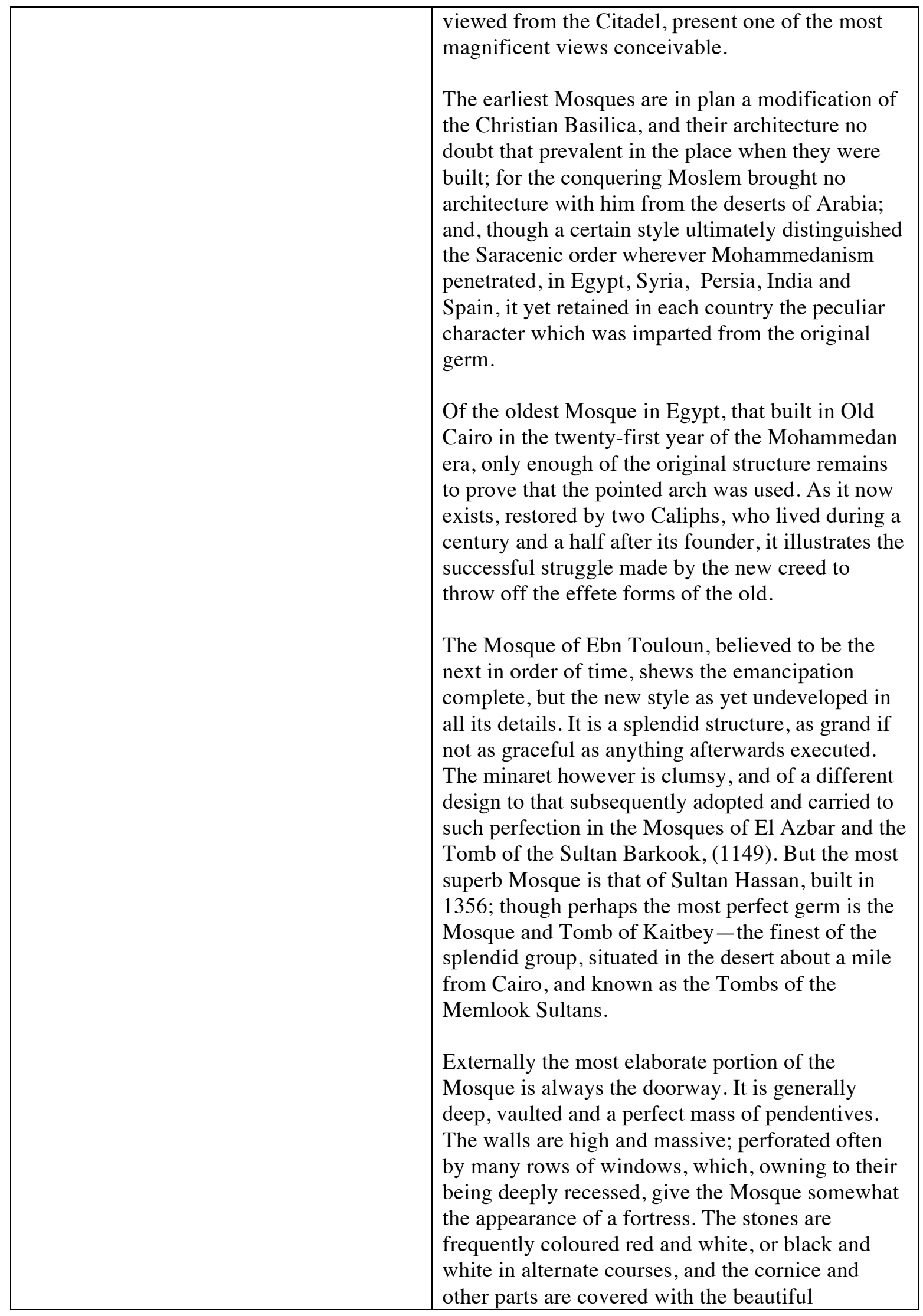




\begin{tabular}{|l|l|}
\hline $\begin{array}{ll}\text { arabesque work which gives so great a charm to } \\
\text { the Saracenic architecture. One or more domes and } \\
\text { sometime as many as six minarets, of three or four } \\
\text { stories each, crown the whole, and impart the } \\
\text { gracefulness which we always associate with this } \\
\text { style. }\end{array}$ \\
$\begin{array}{ll}\text { As might be expected all the Provincial Mosques } \\
\text { are vastly inferior to those of the Capital. Some } \\
\text { faint attempt is often made to ornament the } \\
\text { doorway, and the minarets are occasionally } \\
\text { beautiful; but they seldom possess much merit, } \\
\text { though they add greatly to the picturesqueness of } \\
\text { almost every landscape. }\end{array}$ \\
\hline NOTES & $\begin{array}{l}\text { J.D., JR. } \\
\text { Library of Egyptology, Special Collections. }\end{array}$ \\
\hline
\end{tabular}

\begin{tabular}{|l|l|}
\hline IMAGE & \\
& \\
& \\
& \\
\hline TITLE & Country Mosque [Mosque at Minieh] \\
\hline MEDIUM & Albumen print from waxed paper negative \\
\hline CONCORDANCE & AMC, Photographic Views Taken in Egypt \\
& $21 \times 28$ cm \\
& British Library \\
$20.7 \times 27$ cm \\
\\
Université Laval \\
$19.1 \times 26 \mathrm{~cm}$ \\
Wilbour Library of Egyptology \\
$21 \times 27 \mathrm{~cm}$ \\
\hline MOSQUE AT MINIEH. \\
THE interior of the Mosque contains no other than \\
\hline
\end{tabular}




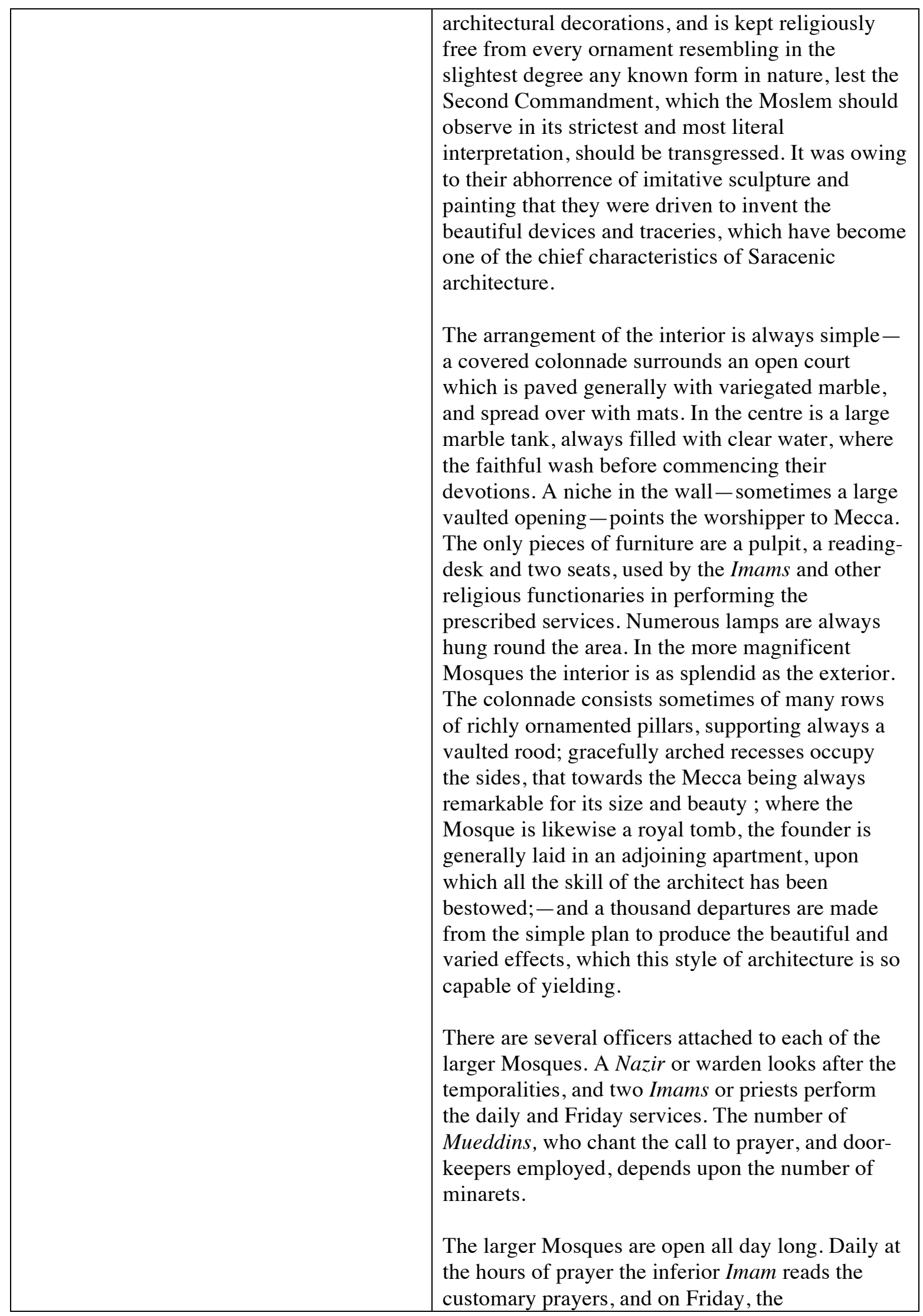




\begin{tabular}{|l|l|}
\hline & $\begin{array}{l}\text { Mahommedan Sunday, his superior recites some } \\
\text { portion of the Koran and preaches. } \\
\text { J.D., JR. }\end{array}$ \\
\hline NOTES & $\begin{array}{l}\text { Image from AMC, Photographic Views Taken in } \\
\text { Egypt. }\end{array}$ \\
\hline
\end{tabular}

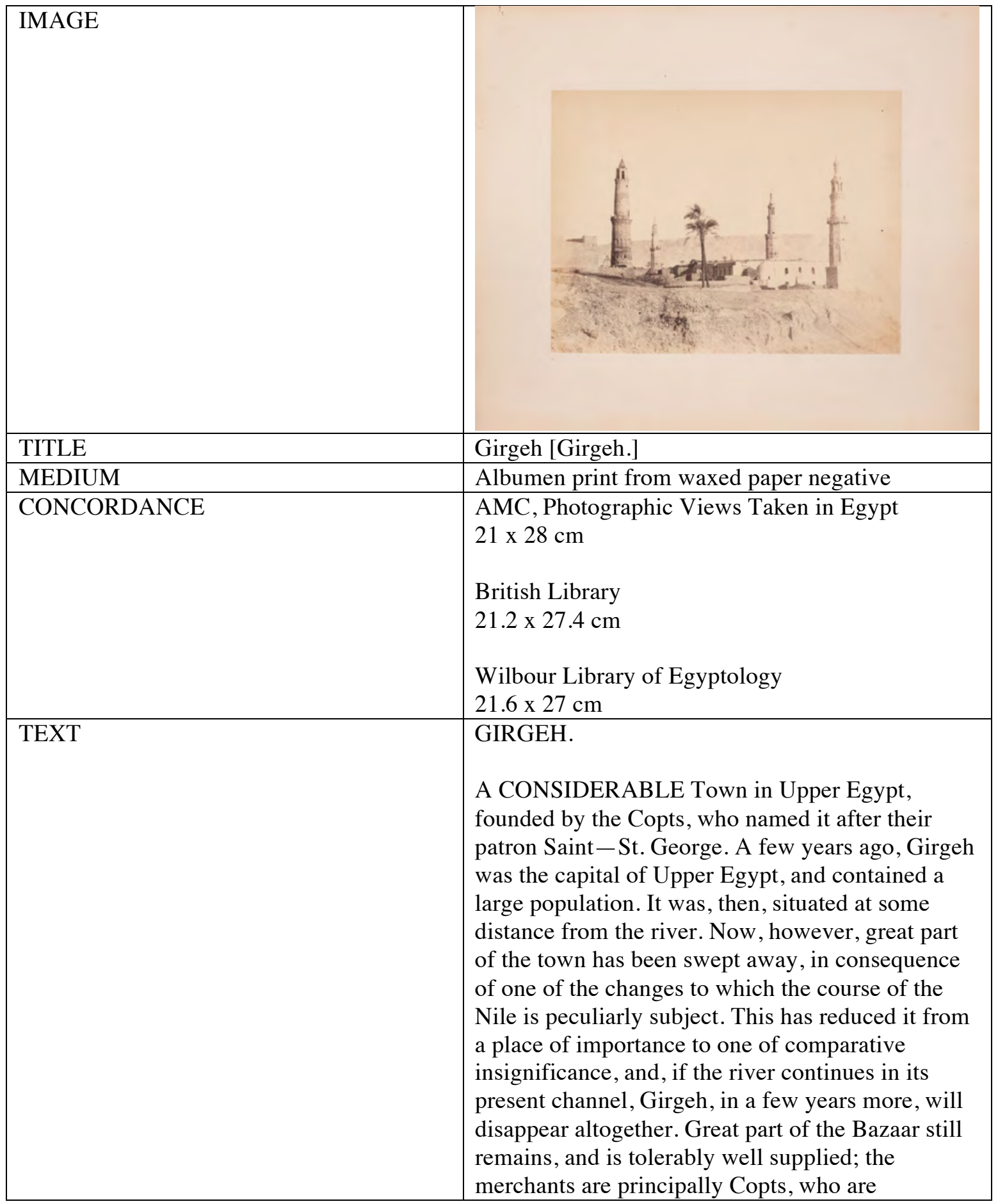




\begin{tabular}{|c|c|}
\hline & $\begin{array}{l}\text { numerous in this part of the Nile valley. There is a } \\
\text { marked difference between them and the other } \\
\text { inhabitants of Egypt. There is no doubt that they } \\
\text { are the descendents of the ancient Egyptians; they } \\
\text { are nominally, at least, Christians, but their } \\
\text { language has ceased to be spoken or even used in } \\
\text { their church services, during the last three } \\
\text { centuries; they now speak and use Arabic only. } \\
\text { There are several Coptic Monasteries in the valley } \\
\text { of the Nile. We visited one yesterday at Shoohag; } \\
\text { it was situated on the Desert, and about five miles } \\
\text { from the river. On approaching it, it presented } \\
\text { more the appearance of a fortress, than of a } \\
\text { religious establishment. A large area was enclosed } \\
\text { in massive walls, about forty feet high, built of } \\
\text { blocks of limestone, carefully hewn, and laid in } \\
\text { courses. The building was evidently of Roman } \\
\text { date. The only entrance was by a small postern in } \\
\text { the south wall. This led into the area, or court, } \\
\text { which contained the Church, the dwellings of the } \\
\text { priests, the stabling, \&c. From the number of } \\
\text { children there seemed little dread of the } \\
\text { community soon dying out. } \\
\text { The Church is situated on the east of the court; it } \\
\text { has five domes, which have been gorgeously inlaid } \\
\text { and ornamented. Now, however, the ornaments } \\
\text { and frescos are much defaced by time. Two rude } \\
\text { pictures adorn the choir, one of the Virgin Mary, } \\
\text { and one of St. George and the Dragon; in this last, } \\
\text { the Virgin is represented in one corner, assisting, it } \\
\text { is supposed, St. George with her countenance and } \\
\text { prayers. } \\
\text { The whole affair is not calculated to inspire } \\
\text { Mussulmans with a very exalted idea of } \\
\text { Christianity. } \\
\text { J.D. }\end{array}$ \\
\hline NOTES & $\begin{array}{l}\text { Image from AMC, Photographic Views Taken in } \\
\text { Egypt. }\end{array}$ \\
\hline
\end{tabular}




\begin{tabular}{|c|c|}
\hline IMAGE & \\
\hline TITLE & Abydos [Abydos] \\
\hline MEDIUM & Albumen print from waxed paper negative \\
\hline CONCORDANCE & $\begin{array}{l}\text { British Library } \\
21.1 \times 26 \mathrm{~cm} \\
\text { Wilbour Library of Egyptology } \\
21.6 \times 26 \mathrm{~cm}\end{array}$ \\
\hline TEXT & $\begin{array}{l}\text { ABYDOS } \\
\text { IS situated in the desert at the base of the Lybian } \\
\text { hills, which here are about three miles, in a direct } \\
\text { line, from the banks of the river. } \\
\text { Bellianeh, about ten miles above Girgeh is the } \\
\text { nearest landing place, and between it and Abydos } \\
\text { there is tolerably good road. We, however, visited } \\
\text { it from Girgeh, mounted on the most wretched } \\
\text { asses we had seen, with rugs or mats for saddles, } \\
\text { and without bridles or stirrups. We found no road, } \\
\text { and were obliged to make long and zigzag courses } \\
\text { through the plain, to enable us to cross the } \\
\text { numerous canals and ditches with which it is } \\
\text { intersected for purposes of irrigation. One of our } \\
\text { party (a Lady) obtained the loan of a very fine and } \\
\text { spirited Arab horse. Her husband exchanged his } \\
\text { donkey for a camel, and I sometimes rode and } \\
\text { sometimes walked. } \\
\text { Abydos, during the old monarchy, was a place of } \\
\text { any considerable importance. It was here that the } \\
\text { different members of Osiris were buried after they } \\
\text { were collected together. It was consequently held } \\
\text { in great sanctity by the ancient Egyptians, to whom } \\
\text { Abydos bore the same relation, as Mecca to the } \\
\text { Moslems, or Jerusalem to the Jews. It was a place } \\
\text { of pilgrimage, and many of the mummies of the }\end{array}$ \\
\hline
\end{tabular}




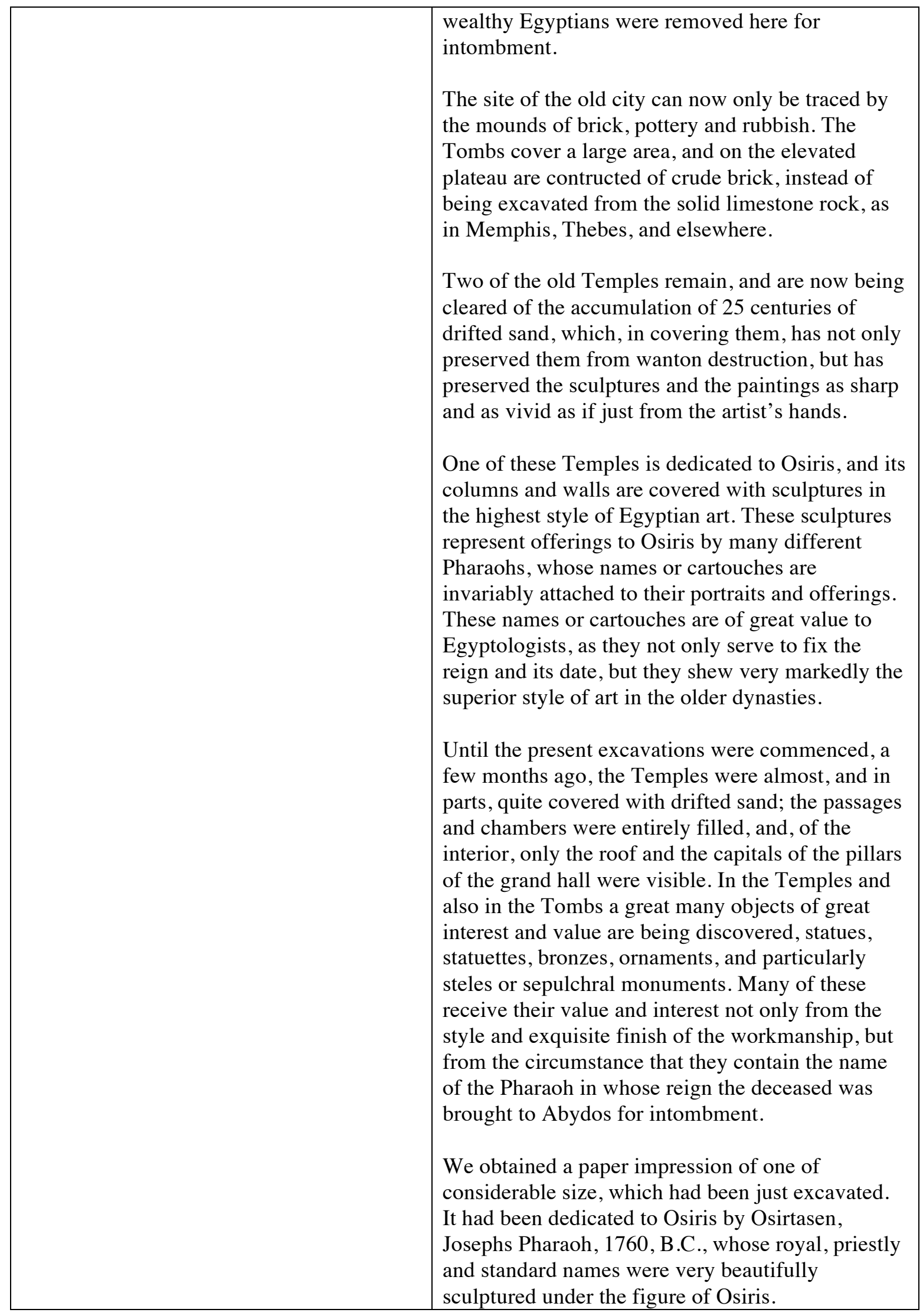




\begin{tabular}{|l|l|}
\hline & $\begin{array}{l}\text { The photograph is of a slab of Sienite, which } \\
\text { formed the jamb of the door of one of the inner } \\
\text { chambers, and will serve as an illustration of the } \\
\text { manner in which the whole of the inner parts of } \\
\text { Egyptian Temples were covered with sculpture, the } \\
\text { entrances, the walls, both inside and outside, the } \\
\text { roofs, pillars, chambers and staircases were all } \\
\text { sculptured, sometimes in intaglio, sometimes in } \\
\text { high relief and sometimes in bas relief, but always } \\
\text { highly colored. }\end{array}$ \\
\hline NOTES & \begin{tabular}{l} 
J.D. \\
Image from Brooklyn Museum Libraries. Wilbour \\
\hline
\end{tabular} \\
\hline
\end{tabular}

\begin{tabular}{|l|l|}
\hline IMAGE & \\
& \\
\hline TITLE & \\
\hline MEDIUM & \\
\hline CONCORDANCE & $\begin{array}{l}\text { British Library } \\
\text { 20 x 27.1 cm }\end{array}$ \\
\hline TEXT & $\begin{array}{l}\text { Wilbour Library of Egyptology } \\
\text { 20.8 } x \text { 26.2 cm }\end{array}$ \\
\hline $\begin{array}{l}\text { DENDERA. } \\
\text { THIS Temple stands among the mounds of the old } \\
\text { town of Tentyris, and is still further hidden and } \\
\text { disfigured by the shapeless ruins of a modern } \\
\text { village. } \\
\text { It is of Ptolemaic and Roman construction, yet may } \\
\text { claim a place among the most interesting of } \\
\text { Egyptian Temples on account of its perfect } \\
\text { preservation. Till that of Edfou was uncovered, it } \\
\text { gave a better idea of the plan and arrangement of }\end{array}$ \\
\hline
\end{tabular}




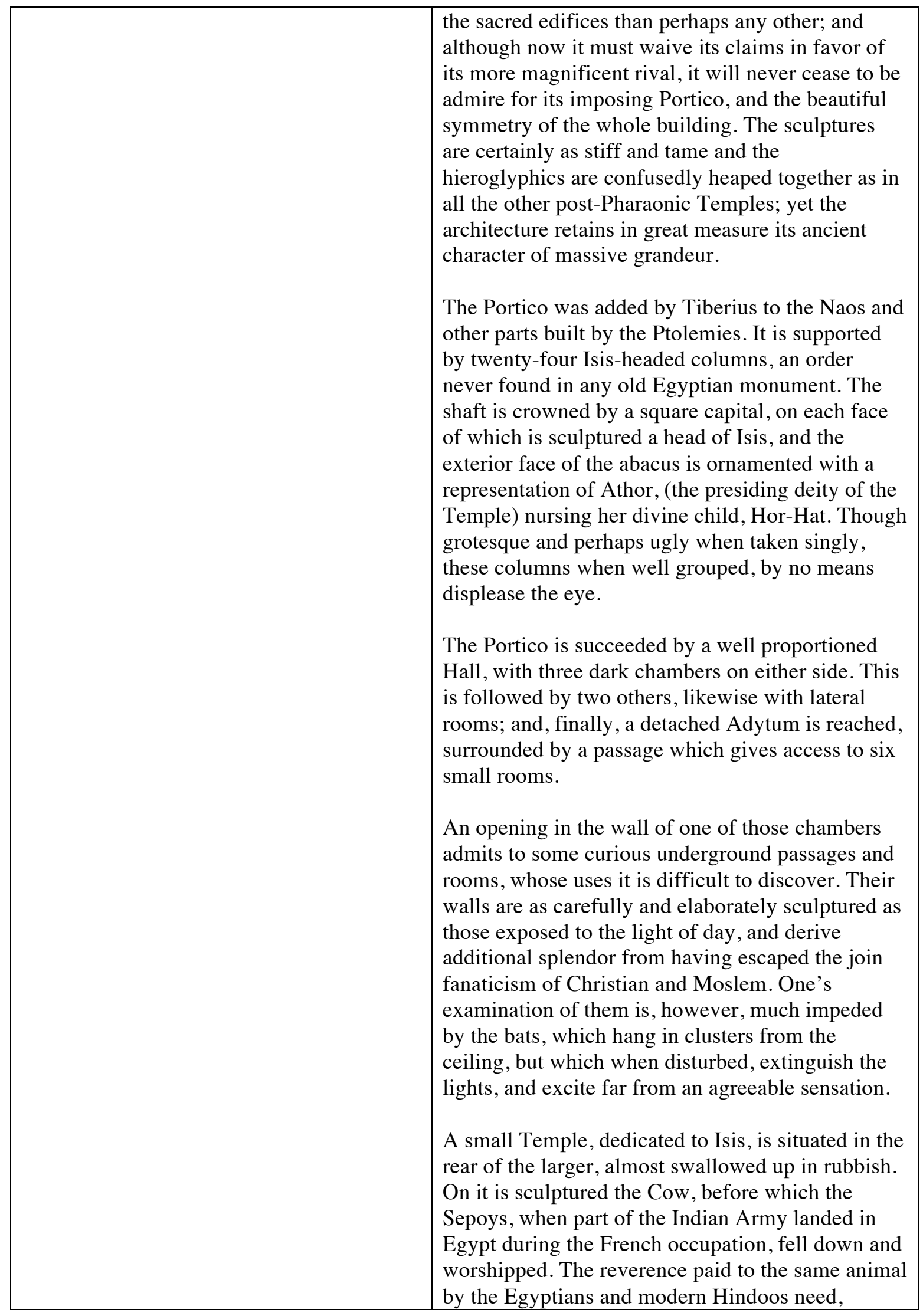




\begin{tabular}{|l|l|}
\hline & $\begin{array}{l}\text { however, be only an accidental circumstance, and } \\
\text { does not therefore necessarily point to any } \\
\text { connection between their religious or to a common } \\
\text { origin. }\end{array}$ \\
$\begin{array}{ll}\text { The view is taken from the back, and gives a good } \\
\text { idea of the monotonous exterior of an Egyptian } \\
\text { Temple, relieved only by the difference in height } \\
\text { of the Portico and Pronaos; and of the sculptures, } \\
\text { which were probably added both within and } \\
\text { without for the purpose of breaking the dead level } \\
\text { of the walls. }\end{array}$ \\
\hline NOTES & $\begin{array}{l}\text { J.D., JR. } \\
\text { Image from Brooklyn Museum Libraries. Wilbour }\end{array}$ \\
\hline
\end{tabular}

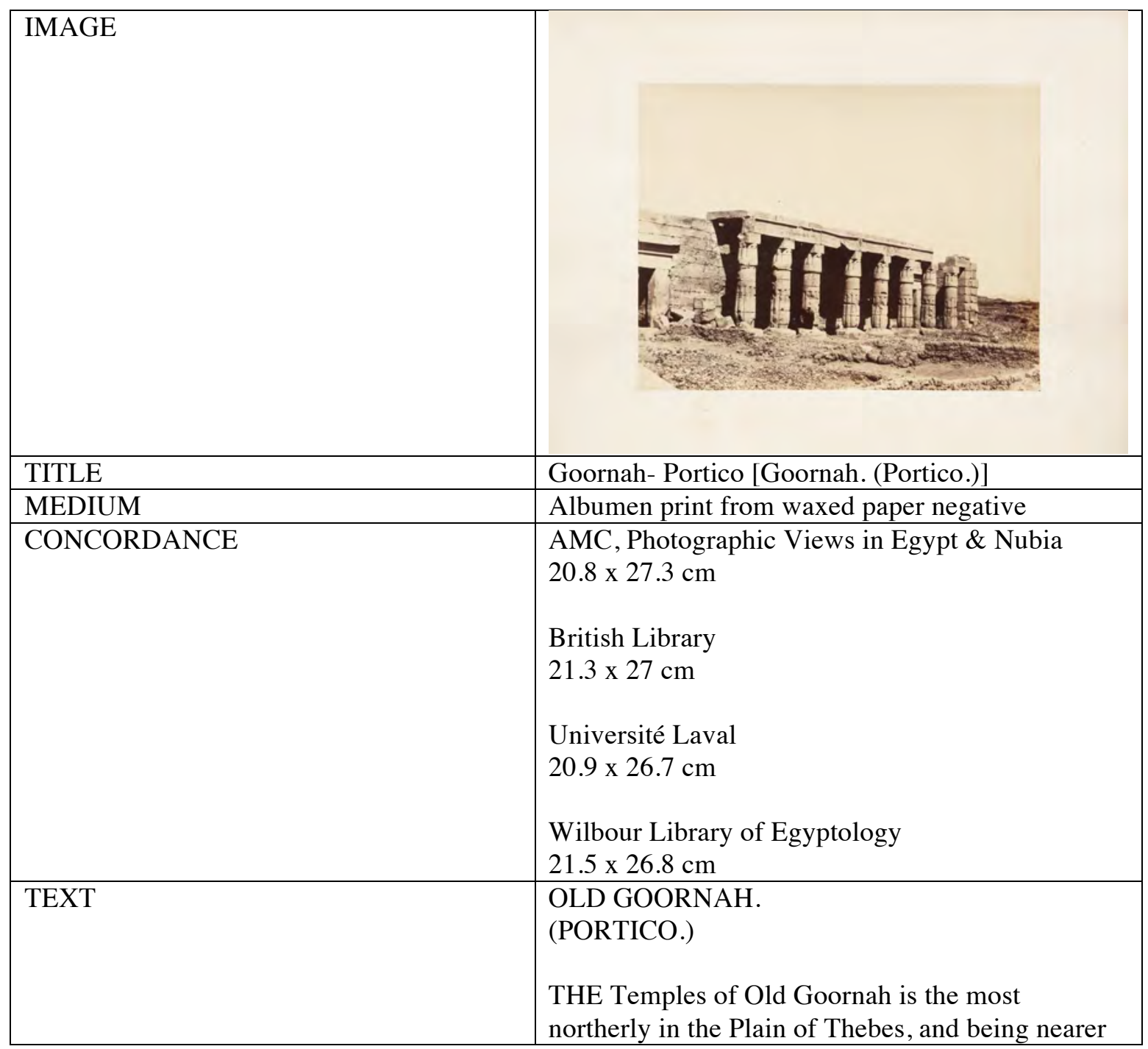




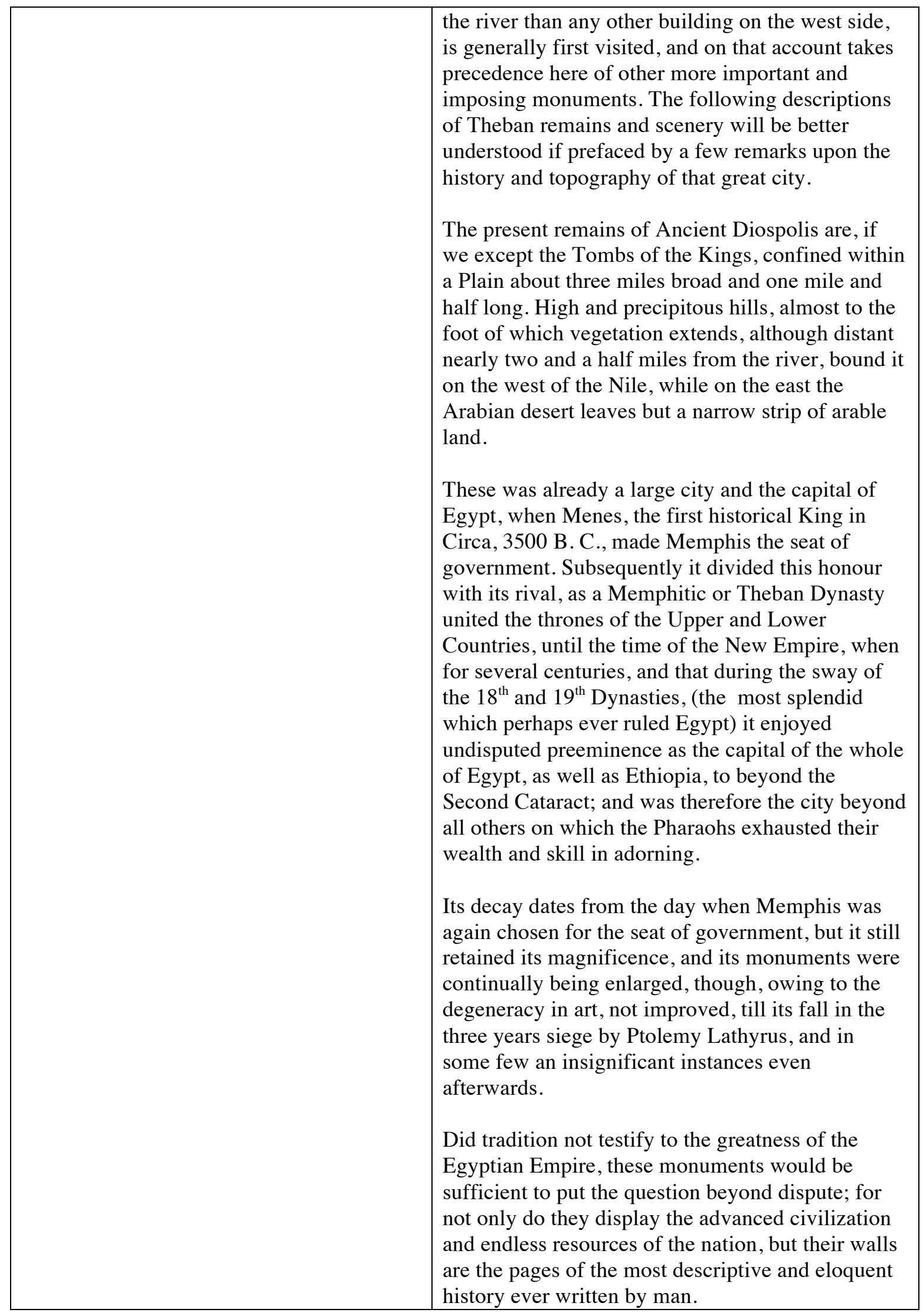




\begin{tabular}{|c|c|}
\hline & $\begin{array}{l}\text { The most stupendous remains of Thebes are its } \\
\text { Temples, the most interesting, as portraying the } \\
\text { manners and customs of the people, are its Tombs. } \\
\text { The former were once numerous, now only six are } \\
\text { in good preservation, viz: those of Karnac and } \\
\text { Luxor on the East Bank, both Temple-Palaces of } \\
\text { the } 18^{\text {th }} \text { and } 19^{\text {th }} \text { Dynasties; and on the West Bank } \\
\text { those of Medeenet Habou, the Rameseum and } \\
\text { Goornah, also of the same brilliant period, and the } \\
\text { small Temple of Dehr el Medineh, erected by the } \\
\text { Ptolemies in a valley to the West of the Plain, } \\
\text { which was a favourite place of sepulture. Mere } \\
\text { fragments of other Temples, sufficient to decide } \\
\text { their site only, are strewed here and there. Two } \\
\text { Colossal Statues, the most prominent objects in the } \\
\text { whole Plain, mark the entrance to a great Temple } \\
\text { of Amunoph III., now almost entirely destroyed ; a } \\
\text { small gateway and some other remains, only now } \\
\text { being uncovered, are all that exist of the Temple- } \\
\text { Palace of the Thothmoses, the great founders of the } \\
\text { New Empire, and here and there a broken column } \\
\text { or a shapeless mound of crude brick bearing the } \\
\text { name of an old Pharaoh, excites our regret that the } \\
\text { desolating hand of man, even more than the } \\
\text { destructive influence of time, should have so } \\
\text { utterly swept away a monument on which so much } \\
\text { human thought and skill had once been spent. } \\
\text { Tombs, royal and private, literally catacomb the } \\
\text { hills and as much of the plain as was beyond the } \\
\text { limit of cultivation. While from the monuments } \\
\text { we acquire our knowledge of the political and } \\
\text { military history of the country, from the Tombs our } \\
\text { whole acquaintance with the private and social life } \\
\text { of the people is derived; and so minutely do they } \\
\text { illustrate it, that we are as familiar with the } \\
\text { manners and customs of the Ancient Egyptians, } \\
\text { who lived } 2,000 \text { years before Christ, as with those } \\
\text { of the Romans of the Augustan age. } \\
\text { J.D. JR. }\end{array}$ \\
\hline NOTES & $\begin{array}{l}\text { Image from AMC, Photographic Views in Egypt \& } \\
\text { Nubia. }\end{array}$ \\
\hline
\end{tabular}




\begin{tabular}{|c|c|}
\hline IMAGE & \\
\hline & 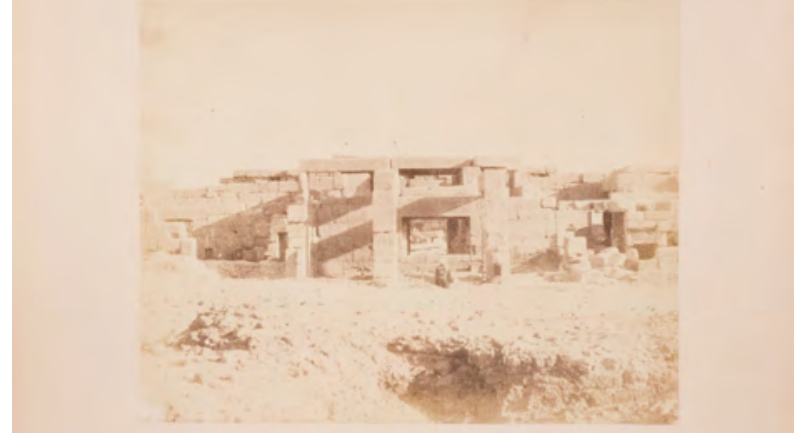 \\
\hline TITLE & $\begin{array}{l}\text { Goornah- Temple from behind [Goornah. (Temple } \\
\text { from Behind.)] }\end{array}$ \\
\hline MEDIUM & Albumen print from waxed paper negative \\
\hline CONCORDANCE & $\begin{array}{l}\text { AMC, Photographic Views Taken in Egypt } \\
20.9 \times 26.4 \mathrm{~cm} \\
\text { British Library } \\
21.3 \times 27.2 \mathrm{~cm} \\
\text { Wilbour Library of Egyptology } \\
21.9 \times 27 \mathrm{~cm}\end{array}$ \\
\hline TEXT & $\begin{array}{l}\text { OLD GOORNAH. } \\
\text { (TEMPLE FROM BEHIND.) } \\
\text { THE approach to this Temple Palace of Sethos and } \\
\text { his son Rameses II. was, as usual, between a row } \\
\text { of Sphinxes and through a gateway, which was } \\
\text { succeeded by a second row of the same mysterious } \\
\text { figures. Only a few mutilated fragments, however, } \\
\text { of these strange ideal beings lie strewn about the } \\
\text { ruins of an Arab village, while the Gateway has } \\
\text { almost disappeared. } \\
\text { The back part of the Temple has shared the same } \\
\text { fate, the only portion in good preservation being } \\
\text { the Colonnade, a central Hall and some side } \\
\text { chambers. } \\
\text { The same dread of uniformity pervades the whole } \\
\text { plan of this building that is met with in almost } \\
\text { every creation of this period: but this neither mars } \\
\text { its beauty nor detracts from the interest which } \\
\text { attaches especially to those portions used as the } \\
\text { Royal Palace. }\end{array}$ \\
\hline
\end{tabular}




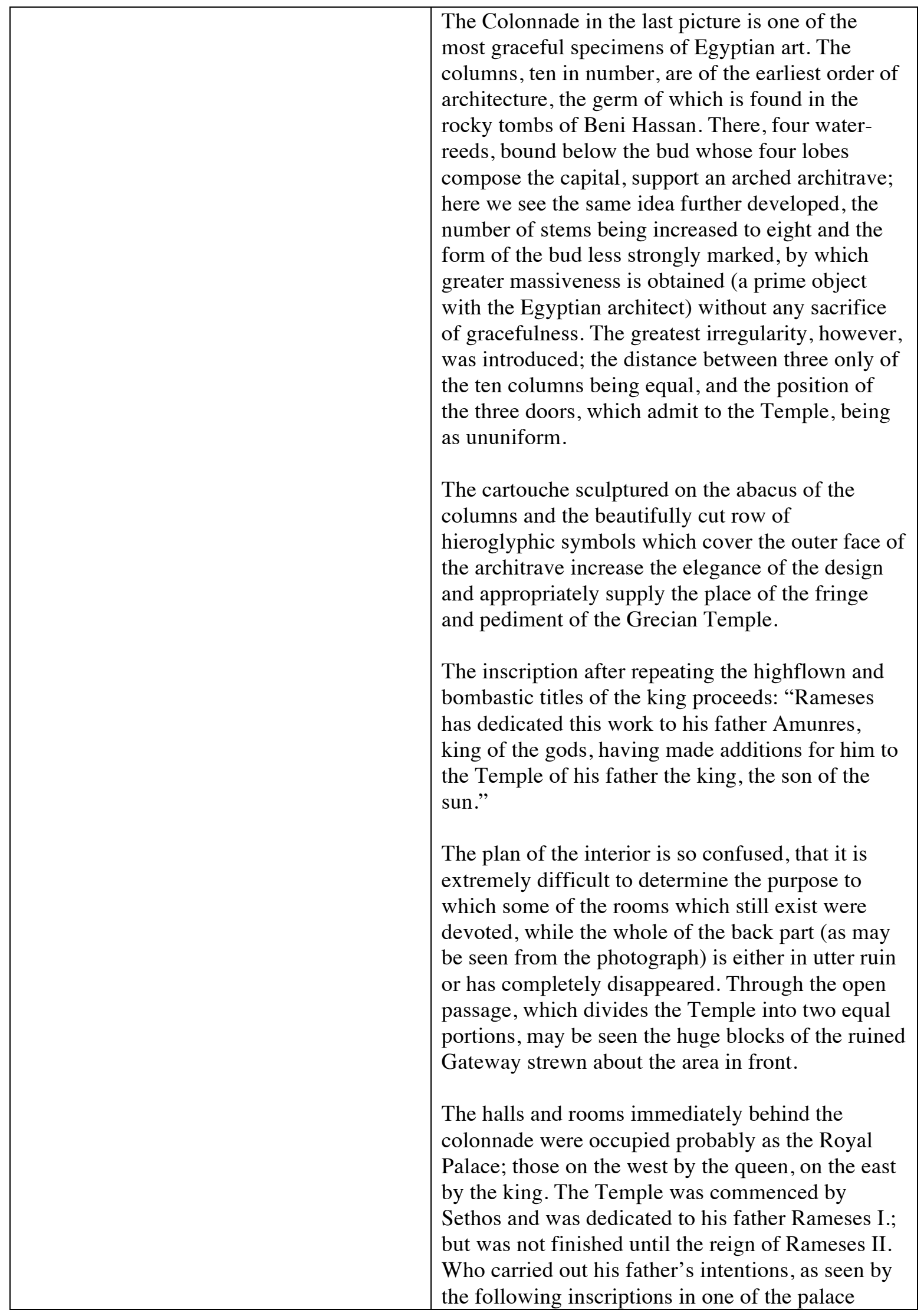




\begin{tabular}{|l|l|}
\hline & $\begin{array}{l}\text { chambers: "this additional work made he, the king } \\
\text { Rameses II., for his father's father the good god } \\
\text { Rameses in place of the dedication of his father } \\
\text { Osirei." }\end{array}$ \\
J.D. JR. \\
\hline NOTES & $\begin{array}{l}\text { Image from AMC, Photographic Views Taken in } \\
\text { Egypt. }\end{array}$ \\
\hline
\end{tabular}

\begin{tabular}{|c|c|}
\hline IMAGE & \\
\hline TITLE & $\begin{array}{l}\text { Valley of the Tombs of the Kings [Valley of the } \\
\text { Tombs of the Kings.] }\end{array}$ \\
\hline MEDIUM & Albumen print from waxed paper negative \\
\hline CONCORDANCE & $\begin{array}{l}\text { AMC, Photographic Views Taken in Egypt } \\
21 \times 27.5 \mathrm{~cm} \\
\text { British Library } \\
21 \times 27.8 \mathrm{~cm} \\
\text { Université Laval } \\
20.1 \times 28.2 \mathrm{~cm} \\
\text { Wilbour Library of Egyptology } \\
21.9 \times 26.4 \mathrm{~cm}\end{array}$ \\
\hline TEXT & $\begin{array}{l}\text { VALLEY OF THE TOMBS OF THE KINGS. } \\
\text { THE discoveries of different explorers since the } \\
\text { French expedition, leave no doubt that the } \\
\text { Pyramids of Ghizeh, of Sakkara, of Dashoor, and } \\
\text { others, which fringe the edge of the Lybian Desert } \\
\text { from opposite Cairo, to Lake Mæris, were the royal } \\
\text { tombs of the Pharaohs of the old monarchy. It } \\
\text { seems also certain, that each Pyramid was built by } \\
\text { the monarch who remains it was intended to hold } \\
\text { after his death. Nothing can more strongly impress }\end{array}$ \\
\hline
\end{tabular}




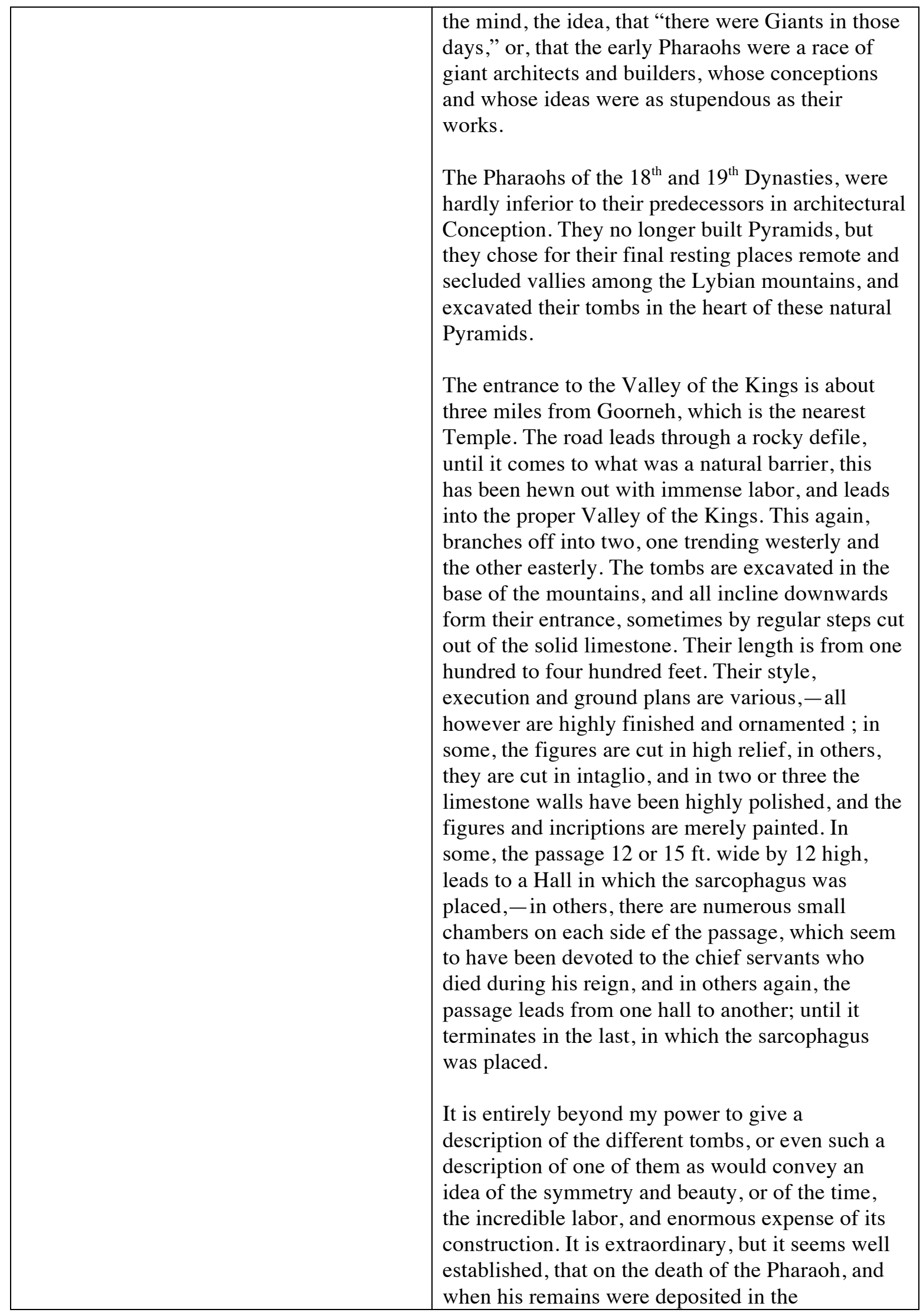




\begin{tabular}{|c|c|}
\hline & $\begin{array}{l}\text { sarcophagus, the whole tomb was walled up, } \\
\text { internally, and externally, and extreme pains were } \\
\text { taken to conceal its entrance. } \\
\text { How peculiar the ideas, or how strong must have } \\
\text { been the feeling of the vanity of life, which } \\
\text { induced mighty monarchs to devote such labor and } \\
\text { wealth to hewing out and decorating such } \\
\text { sumptuous sepulchers in a scene so fearfully } \\
\text { sublime, and so intensely desolate as this Valley. } \\
\text { "Strange race of men! more anxious to prepare } \\
\text { Their last abodes, and make them grand or fair } \\
\text { Than grace their living homes; one gloomy thought } \\
\text { Their souls possessed, one honor still they sought, } \\
\text { To lie in splendor, and to bear in death } \\
\text { Life's form and seeming, all things but its breath. } \\
\quad----------- \text { They only saw the Tomb, } \\
\text { Wished there to rest their unconsuming clay, } \\
\text { And dream, in pomp, eternal years away." } \\
\text { We spent two days among the tombs of the kings, } \\
\text { and obtained some very good paper impressions, } \\
\text { principally in the tomb of Sethos. } \\
\text { Fortunately the weather was unusually cool for the } \\
\text { season- during a former visit the heat was so } \\
\text { intense, and the reflection of the sun's rays upon } \\
\text { the white rocks so overpowering, that I no longer } \\
\text { wondered that two gentlemen of the French } \\
\text { expedition fell victims to their visit to this rocky } \\
\text { gorge. } \\
\text { J.D. }\end{array}$ \\
\hline NOTES & $\begin{array}{l}\text { Image from AMC, Photographic Views Taken in } \\
\text { Egypt. }\end{array}$ \\
\hline
\end{tabular}




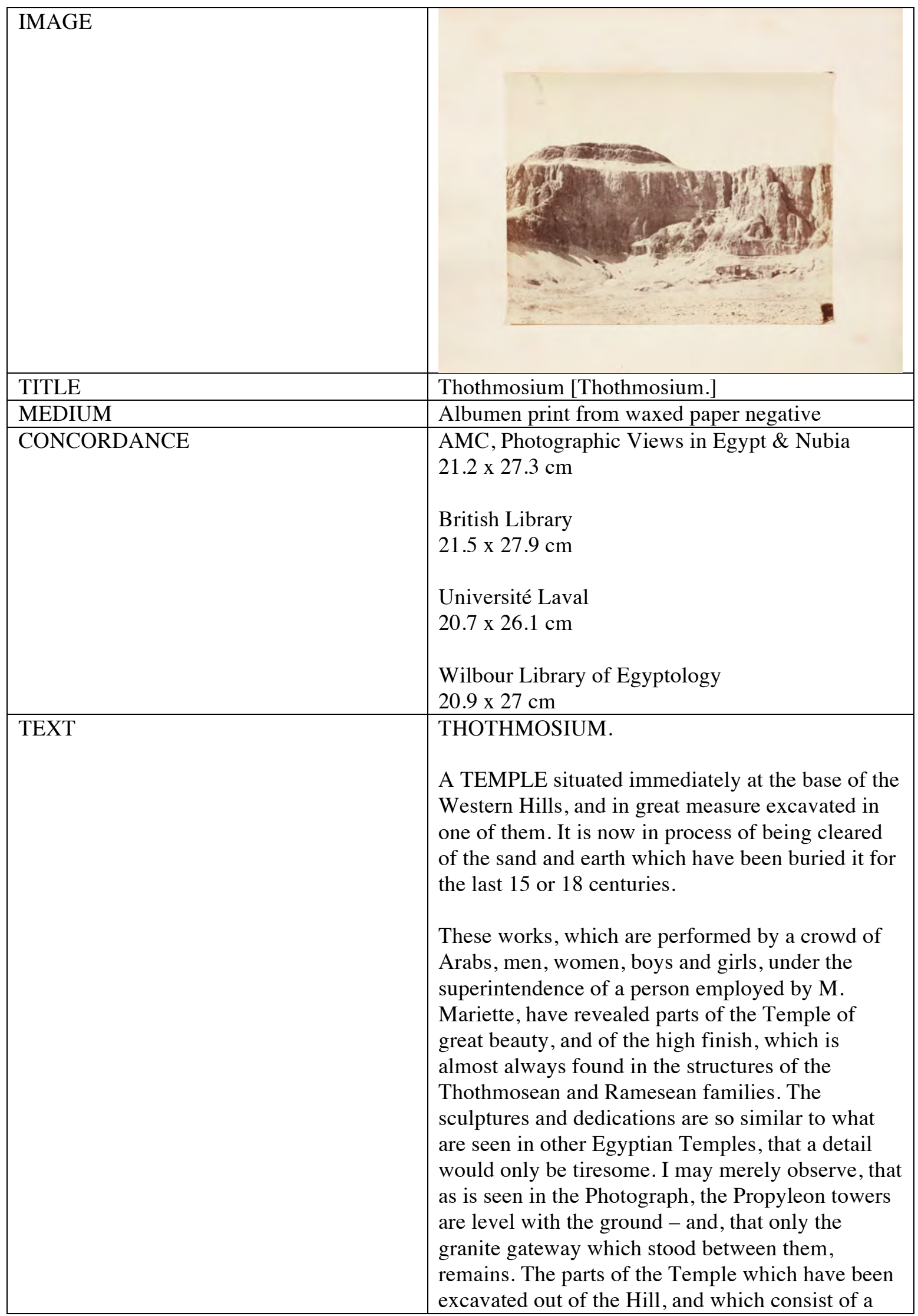




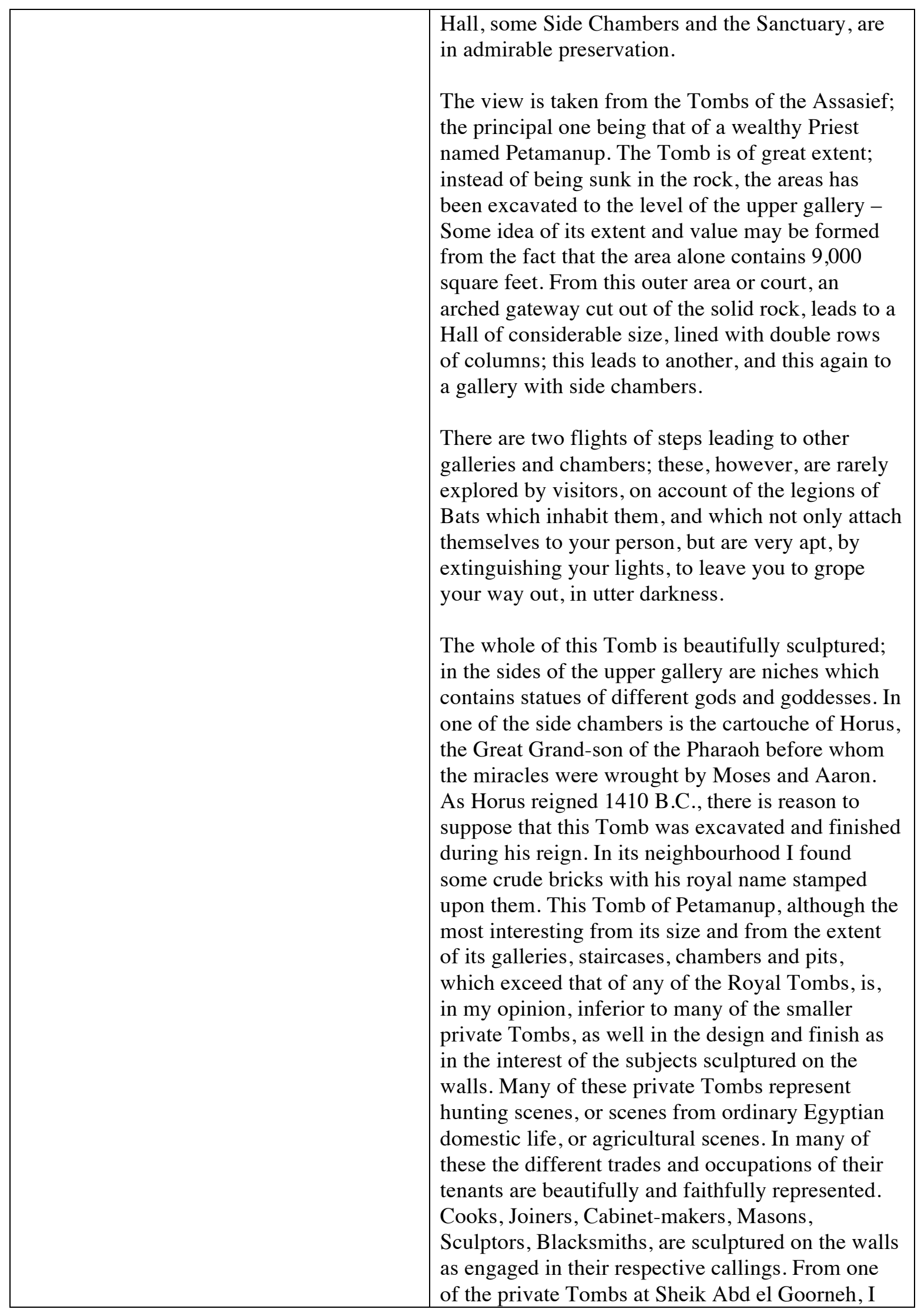




\begin{tabular}{|l|l|}
\hline & $\begin{array}{l}\text { obtained a paper impression of a number of } \\
\text { Upholsterers carrying home furniture, which } \\
\text { consisted of a Table, Stands, Water Coolers, Wine } \\
\text { Jars, a Mirror, \&c., \&c.. ; among them were an } \\
\text { Arm-chair and Sofa, which in design are no way } \\
\text { inferior to many which may now be found in Mr. } \\
\text { Drum's show-rooms. }\end{array}$ \\
& J.D. \\
\hline NOTES & $\begin{array}{l}\text { Image from AMC, Photographic Views in Egypt \& } \\
\text { Nubia. }\end{array}$ \\
\hline
\end{tabular}

\begin{tabular}{|c|c|}
\hline \multicolumn{2}{|l|}{ IMAGE } \\
\hline & 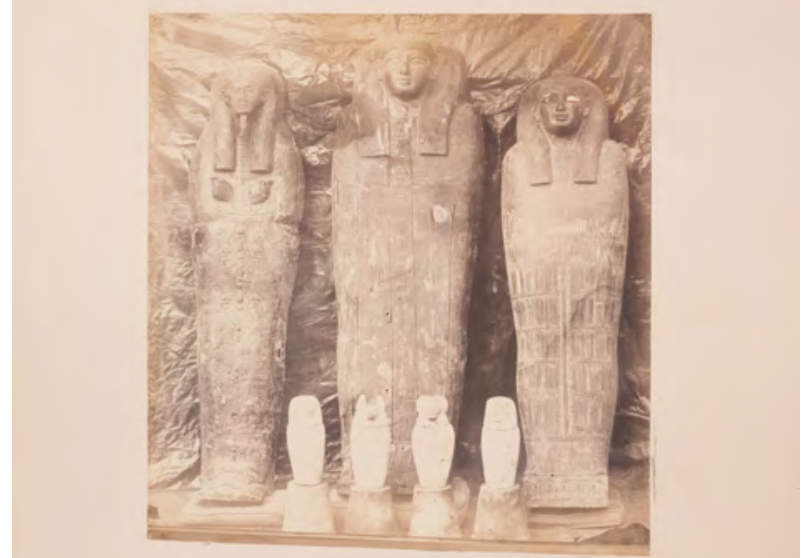 \\
\hline TITLE & Mummies [Mummies.] \\
\hline MEDIUM & $\begin{array}{l}\text { Albumen print from waxed paper negative or from } \\
\text { wet plate collodion }\end{array}$ \\
\hline CONCORDANCE & $\begin{array}{l}\text { AMC, Photographic Views Taken in Egypt } \\
23.3 \times 22 \mathrm{~cm} \\
\text { British Library } \\
21.3 \times 26.6 \mathrm{~cm} \\
\text { Wilbour Library of Egyptology } \\
24 \times 28.7 \mathrm{~cm}\end{array}$ \\
\hline TEXT & $\begin{array}{l}\text { MUMMIES. } \\
\text { THERE is as great a difference in quality among } \\
\text { the thousands of Mummies found in the Tombs in } \\
\text { the valley of the Nile, as there doubtless was in the } \\
\text { wealth and social standing of the old inhabitants. } \\
\text { Some were expensively and carefully mummified, } \\
\text { covered with gold leaf, wrapped in bandages of the } \\
\text { finest linen, decorated with the rings, necklaces }\end{array}$ \\
\hline
\end{tabular}




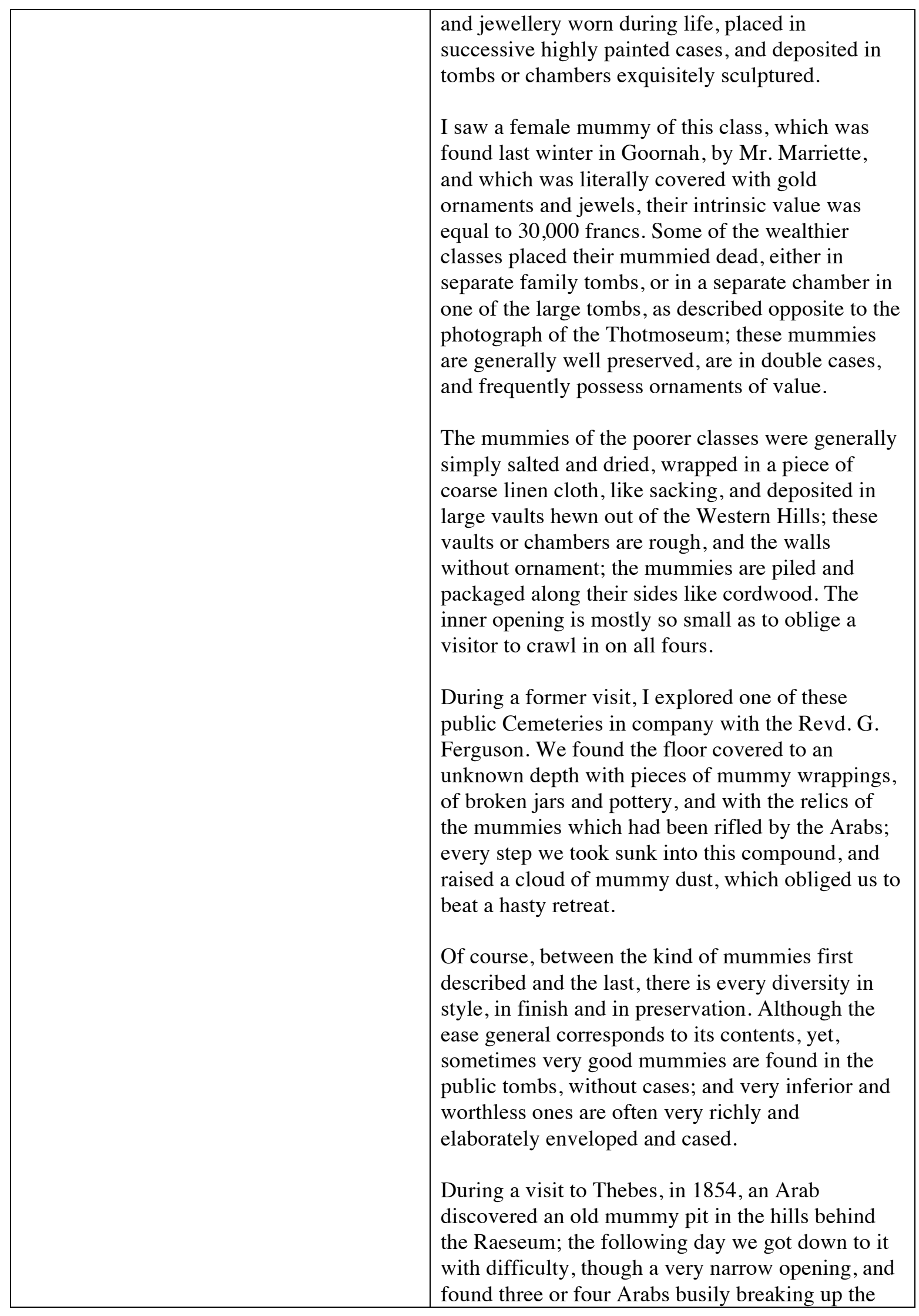




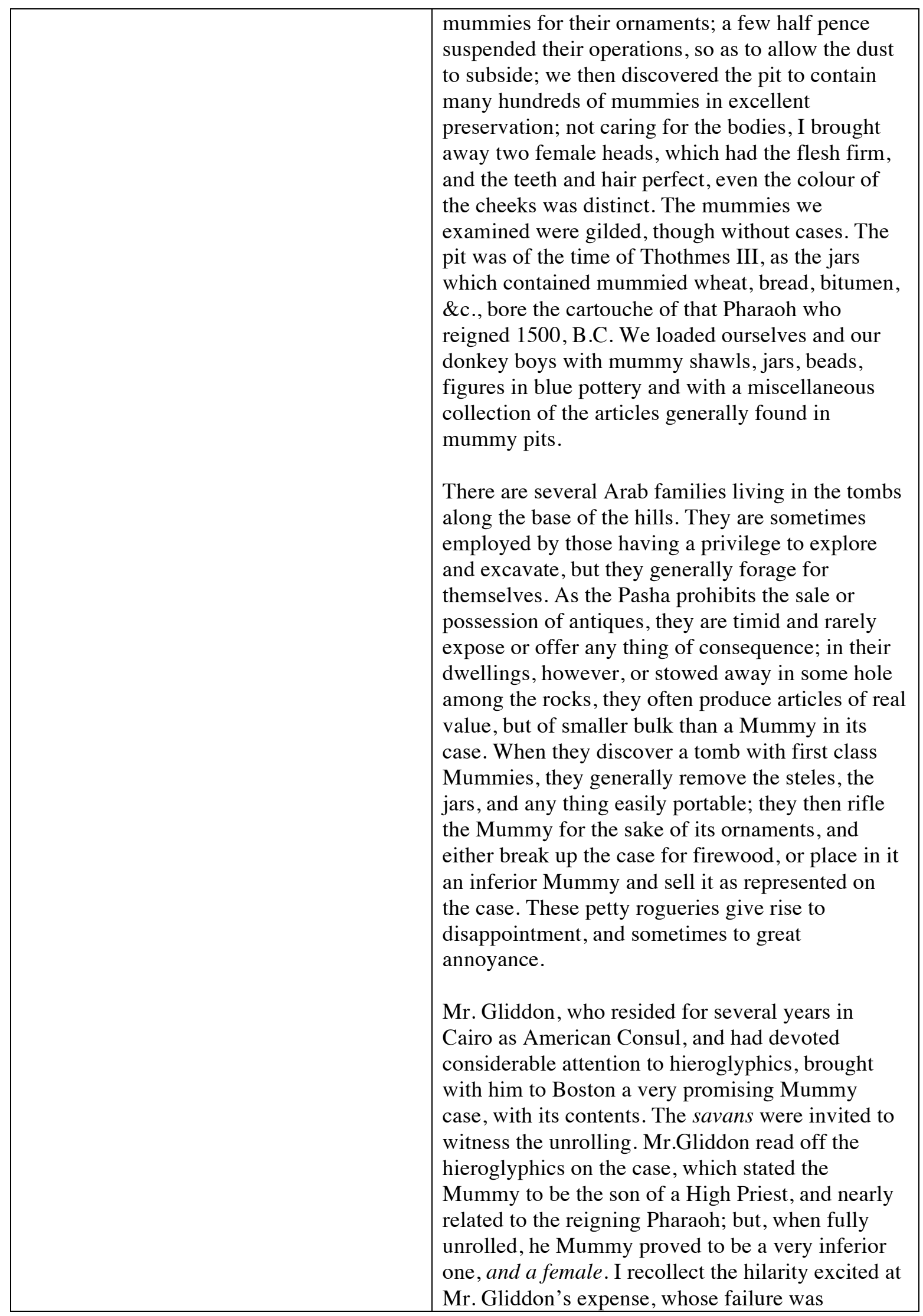




\begin{tabular}{|c|c|}
\hline & $\begin{array}{l}\text { attributed to his inability to read the hieroglyphics. } \\
\text { The three Mummies represented in the photograph } \\
\text { were brought from Thebes for a very worthy and } \\
\text { enterprising gentleman, Mr.Barnet, the proprietor } \\
\text { of the Museum at Niagara. The one with the beard } \\
\text { of Osiris, proved to be a female, another was a } \\
\text { very indifferent Mummy; neither of them were the } \\
\text { original occupants of their cases; the middle one, } \\
\text { in the plate, however, proved to be a first class } \\
\text { specimen. In Mr. Barnet's letter to me, he says, } \\
\text { "We unrolled the Mummies two months ago. One } \\
\text { of them is the finest every brought to this country, } \\
\text { as good, perhaps, if not better, than any in the } \\
\text { world; the face and features are as perfect as } \\
\text { possible. He was without doubt a warrior, or, at all } \\
\text { events, was killed in good health, for there are } \\
\text { several wounds and scars on his face and breast." } \\
\text { When at Goorneh one day, an Arab brought me a } \\
\text { strange looking package, which he said contained a } \\
\text { Mummy, it seemed a bundle of papyrus stalks, } \\
\text { about thirty inches long, was thick in the middle } \\
\text { and tapered to each end, it was tied up by several } \\
\text { pieces of cord; it looked like the description of a } \\
\text { modern ladies' bustle. Since our return we opened } \\
\text { it and found the outer covering to be papyrus reeds } \\
\text { strung together like matting. Within, were several } \\
\text { bandages of coarse linen, which enveloped the } \\
\text { Mummy of a new born child, in tolerable } \\
\text { preservation. } \\
\text { At the feet of the Mummy cases represented in the } \\
\text { photograph, are four vases, the lids of which are } \\
\text { sculptured in the likenesses of the four Genii of } \\
\text { Amenti, as seen in the plate of the Judgment } \\
\text { Scene. These vases are of coarse marble, and } \\
\text { contained the heart, the lungs, the stomach, and the } \\
\text { intestines of the Mummy at whose feet they were } \\
\text { placed in the tomb. Each figure had especial } \\
\text { charge of a particular portion of the viscera. } \\
\text { J.D. }\end{array}$ \\
\hline NOTES & $\begin{array}{l}\text { Image from AMC, Photographic Views Taken in } \\
\text { Egypt. Photograph has been cropped in AMC, } \\
\text { Photographic Views Taken in Egypt and in the } \\
\text { British Library album, which explains their smaller } \\
\text { dimensions. }\end{array}$ \\
\hline
\end{tabular}




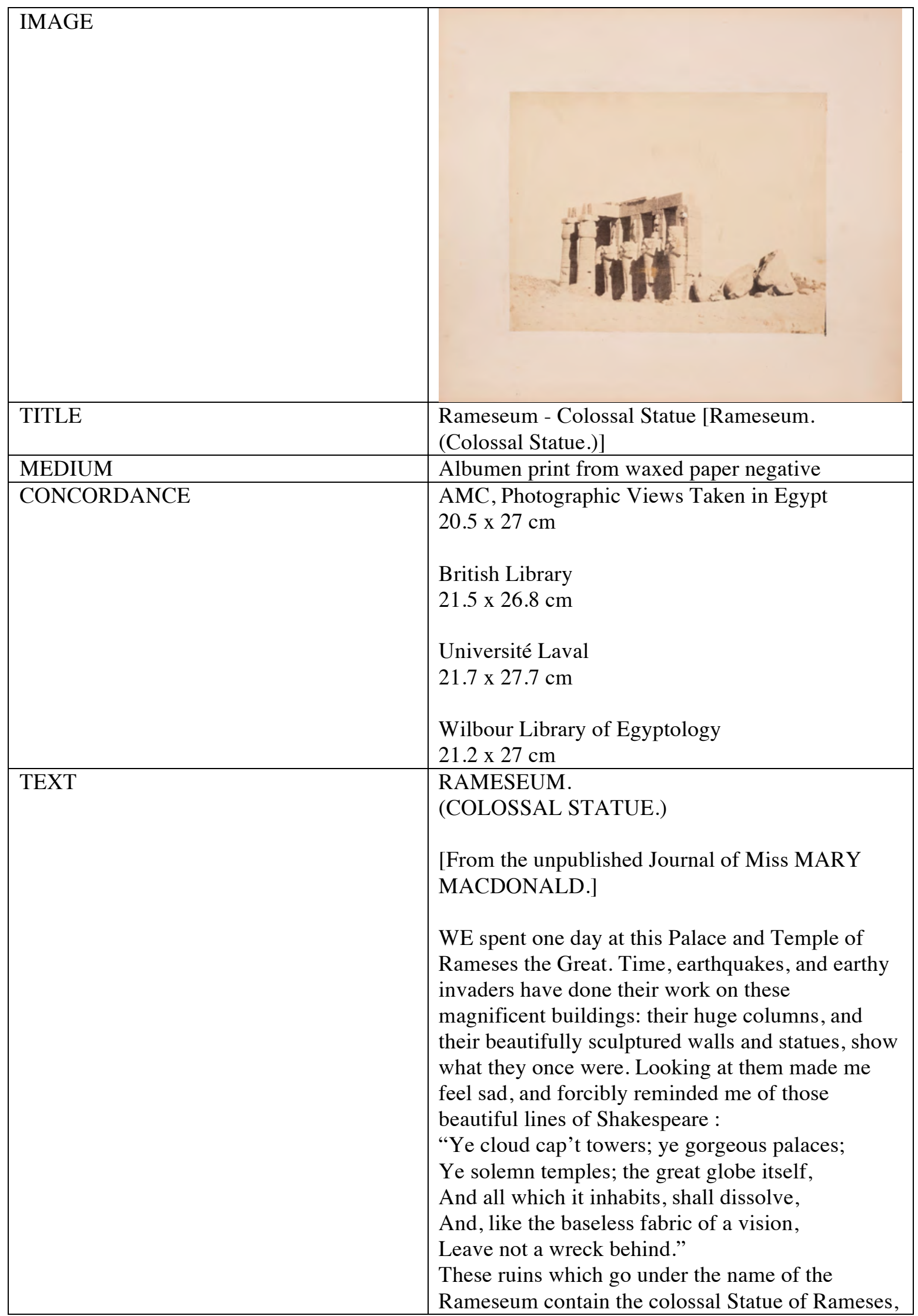




\begin{tabular}{|c|c|}
\hline & $\begin{array}{l}\text { sculpture out of a single block of red granite; it was } \\
\text { in a sitting posture, was sixty feet in height, above } \\
\text { its pedestal, weighed } 887 \text { tons and measured } 24 \\
\text { feet across the shoulders. The figures and } \\
\text { hieroglyphics which are cut upon its surface, are as } \\
\text { sharp and as highly polished, as if just finished. } \\
\text { It is now lying on its back, having been thrown } \\
\text { down by the Persians, under Cambyses. } \\
\text { The ruins of the Temple are extensive and have } \\
\text { been enclosed by massive walls of crude brick } \\
\text { which seem to have been the works of different } \\
\text { Pharaohs, who reigned long before the times of } \\
\text { Rameses; these walls were very high and broad; } \\
\text { the remains of one which we ascended are nearly } \\
30 \text { feet high, and } 15 \text { feet thick. The bricks are very } \\
\text { large, and are all stamped with the royal name of } \\
\text { the Pharaoh in whose reign they were made; many } \\
\text { of the bricks are still perfect and uninjured. In one } \\
\text { wall, they bore the names of Thothmes I. and his } \\
\text { queen, who reigned } 1532 \text { B.C. In another wall, } \\
\text { which we explored, the bricks bore a name of } \\
\text { much greater interest to us, that of Thothmes III., } \\
\text { the Pharaoh of the Exodus, and before whom the } \\
\text { miracles were wrought by Moses and Aaron. } \\
\text { Doubts have been expressed whether these bricks } \\
\text { were made by the Jews, who are supposed to have } \\
\text { chiefly resided in Lower Egypt. At any rate, the } \\
\text { bricks which we examined, and brought away with } \\
\text { us, contained very little, and some of them no } \\
\text { straw,- while the bricks made in the times of } \\
\text { Thothmes I. contained a great quality of straw and } \\
\text { rushes. }\end{array}$ \\
\hline NOTES & $\begin{array}{l}\text { Image from AMC, Photographic Views Taken in } \\
\text { Egypt. }\end{array}$ \\
\hline
\end{tabular}




\begin{tabular}{|c|c|}
\hline IMAGE & \\
\hline TITLE & $\begin{array}{l}\text { Rameseum, from the S.E. [Rameseum. (From the } \\
\text { South.)] }\end{array}$ \\
\hline MEDIUM & Albumen print from waxed paper negative \\
\hline CONCORDANCE & $\begin{array}{l}\text { British Library } \\
21.4 \times 25.9 \mathrm{~cm} \\
\text { Wilbour Library of Egyptology } \\
21.4 \times 27 \mathrm{~cm}\end{array}$ \\
\hline TEXT & $\begin{array}{l}\text { RAMESEUM. } \\
\text { (FROM THE SOUTH.) } \\
\text { THE Temple-Palace of the Rameseum, of which } \\
\text { the Oseiride figures opposite decorate the second } \\
\text { area, may lay claim to being artistically the most } \\
\text { perfect building in the valley of the Nile. For once } \\
\text { the Egyptian architect seems to have forgotten his } \\
\text { abhorrence of symmetry and to have laid down a } \\
\text { design, the regularity and beautiful proportions of } \\
\text { which, have placed his work among the } \\
\text { architectural masterpieces of the world. } \\
\text { The Temple was never large-if we may judge by } \\
\text { what remains, and which unfortunately is hardly } \\
\text { enough to enable us to determine with certainty } \\
\text { even its ground plan: yet some of its parts were } \\
\text { more massive than those of any other temple in } \\
\text { Egypt-and these still by their contrast to the rest } \\
\text { of the building give to the whole a grandeur of } \\
\text { effect, attained elsewhere only at Karnac. The } \\
\text { massive Towers of the Propylon which most once } \\
\text { have thrown their shade during great part of the } \\
\text { day over nearly the whole of the outer Court, are } \\
\text { now in ruins,- and soon, the noble battle scenes } \\
\text { which cover their interior walls - and which would } \\
\text { be the most fit illustration of Homer, (for they } \\
\text { breathe the very spirit of the Illiad,) will soon be }\end{array}$ \\
\hline
\end{tabular}




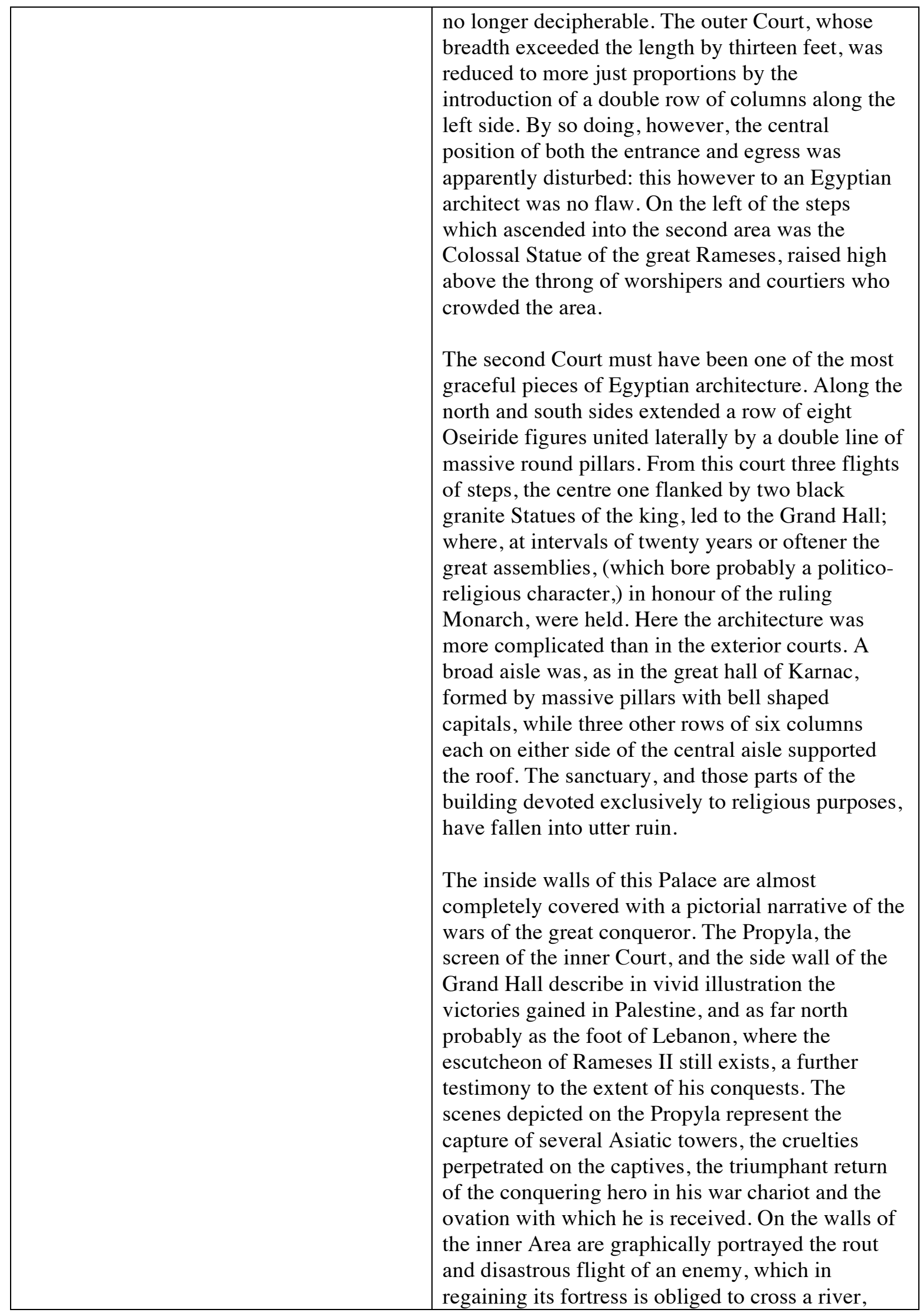




\begin{tabular}{|l|l|}
\hline & $\begin{array}{l}\text { where more are drowned than perished in the } \\
\text { battle; and still another scene in the Grand Hall } \\
\text { describes the capture of a fortress, by which } \\
\text { considerable light is thrown upon the mode of } \\
\text { warfare; and the early use of the testudo and other } \\
\text { instruments of offence and defence, employed long } \\
\text { afterwards by western nations, is discovered. }\end{array}$ \\
J.D., JR. \\
\hline NOTES & $\begin{array}{l}\text { Image from Brooklyn Museum Libraries. Wilbour } \\
\text { Library of Egyptology, Special Collections. }\end{array}$ \\
\hline
\end{tabular}

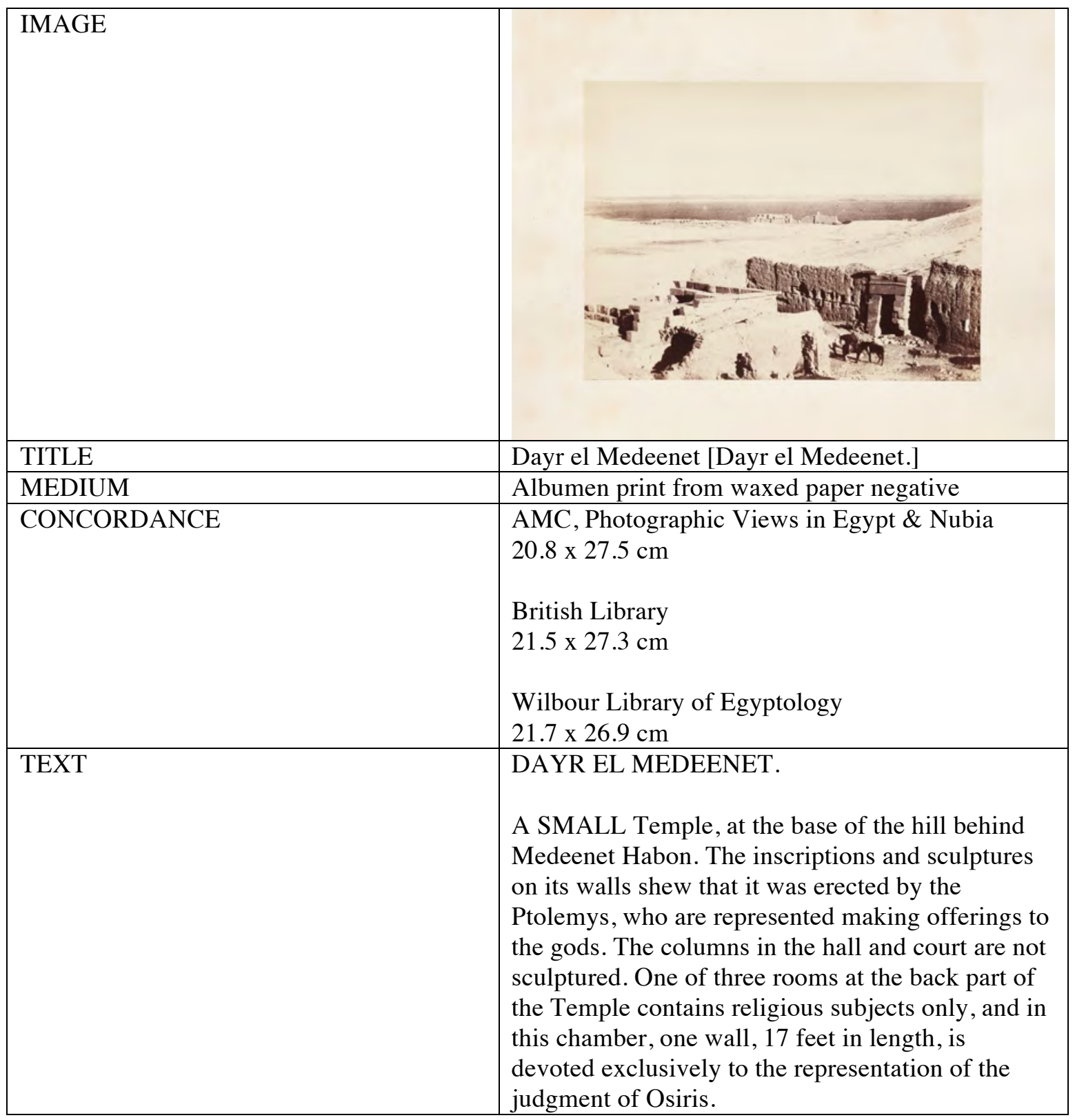




\begin{tabular}{|l|l|}
\hline & $\begin{array}{l}\text { This Photograph of Dayr el Medeenet is taken } \\
\text { from a small mound immediately behind it, and } \\
\text { shews the neighbouring Temple of Rameses, with } \\
\text { its crude brick arched Tombs, and with the plain of } \\
\text { Thebes, bounded by the Nile and the Arabian Hills, } \\
\text { in the distance. }\end{array}$ \\
J.D. \\
\hline NOTES & $\begin{array}{l}\text { Image from AMC, Photographic Views in Egypt \& } \\
\text { Nubia. In the British Library version there is an } \\
\text { inscription written by Dr. James Douglas that } \\
\text { states "Took w paper impressions in 1863." }\end{array}$ \\
\hline
\end{tabular}

\begin{tabular}{|c|c|}
\hline IMAGE & \\
\hline & 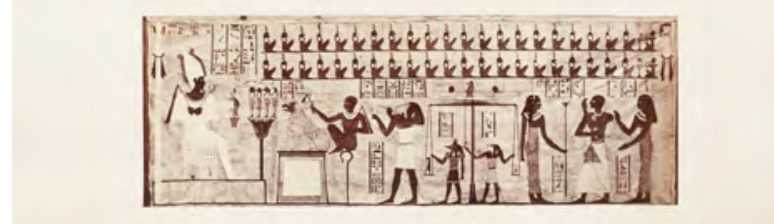 \\
\hline TITLE & Judgment Scene [Judgment Scene.] \\
\hline MEDIUM & $\begin{array}{l}\text { Albumen print from waxed paper negative. The } \\
\text { negative also may have been retouched. }\end{array}$ \\
\hline CONCORDANCE & $\begin{array}{l}\text { AMC, Photographic Views in Egypt \& Nubia } \\
9.5 \times 27.1 \mathrm{~cm} \\
\text { British Library } \\
12.2 \times 34.5 \mathrm{~cm} \\
\text { Wilbour Library of Egyptology } \\
19.5 \times 28.8 \mathrm{~cm}\end{array}$ \\
\hline TEXT & $\begin{array}{l}\text { JUDGMENT SCENE. } \\
\text { THE scene, from which this Photograph has been } \\
\text { taken, is sculptured on the west wall of a side } \\
\text { chamber in the Temple of Dayr el Medeeneh at } \\
\text { Thebes, and presents one of the best } \\
\text { representations of a subject which is very often } \\
\text { depicted on the sepulchral steles, on the mummy } \\
\text { cases, and on the Papyri found in the tombs. } \\
\text { It is very well represented on the inner case of a } \\
\text { mummy in the possession of Mr. Barnet, of } \\
\text { Niagara. }\end{array}$ \\
\hline
\end{tabular}




\begin{tabular}{|c|c|}
\hline & $\begin{array}{l}\text { The figures explain themselves. The deceased is } \\
\text { introduced between the Thmei, the figures of Truth } \\
\text { and Justice, and by them presented to the inferior } \\
\text { deities, who superintend the weighing of his } \\
\text { actions during life. Hapi, the monkey headed } \\
\text { divinity sits on the balance, - Anubis and Horus } \\
\text { adjust the scales, - and Thoth stands before Osiris, } \\
\text { and writes on his tablets the sentence, whether the } \\
\text { soul of the deceased is to enjoy eternal felicity in } \\
\text { the regions of the West, - or be driven back into } \\
\text { the world in the form of a pug, or a wolf, or of the } \\
\text { animal whose habits the most closely corresponded } \\
\text { to his own, during his lifetime. } \\
\text { Sir G. Wilkinson, in describing this sculptured } \\
\text { wall, says, "Before Osiris, the four Genii of } \\
\text { Amenti stand on a Lotus Flower, and a figure of } \\
\text { Harpocrates, seated on a crook of Osiris between } \\
\text { the scales and the entrance to the divine abode, } \\
\text { which is guarded by Cerberus, is intended to shew } \\
\text { that the deceased, on admission to that pure state, } \\
\text { must be born again cleansed from all the impurities } \\
\text { of his earthly career. It also represents the idea } \\
\text { common to the Egyptian and other Philosophers } \\
\text { that to die was only to assume a new form, - that } \\
\text { nothing was annihilated, and that dissolution was } \\
\text { only the prerunner of reproduction. Above, in two } \\
\text { lines sit the forty-two assessors, whose office was } \\
\text { to assist in judging the dead" - by receiving the } \\
\text { confession of his guilt or innocence of the forty- } \\
\text { two sins, which were all that were embraced in the } \\
\text { Egyptian ritual of the dead. } \\
\text { J.D. }\end{array}$ \\
\hline NOTES & $\begin{array}{l}\text { Image from AMC, Photographic Views in Egypt \& } \\
\text { Nubia. Image is cropped in AMC, Photographic } \\
\text { Views in Egypt \& Nubia and in British Library } \\
\text { album. }\end{array}$ \\
\hline
\end{tabular}




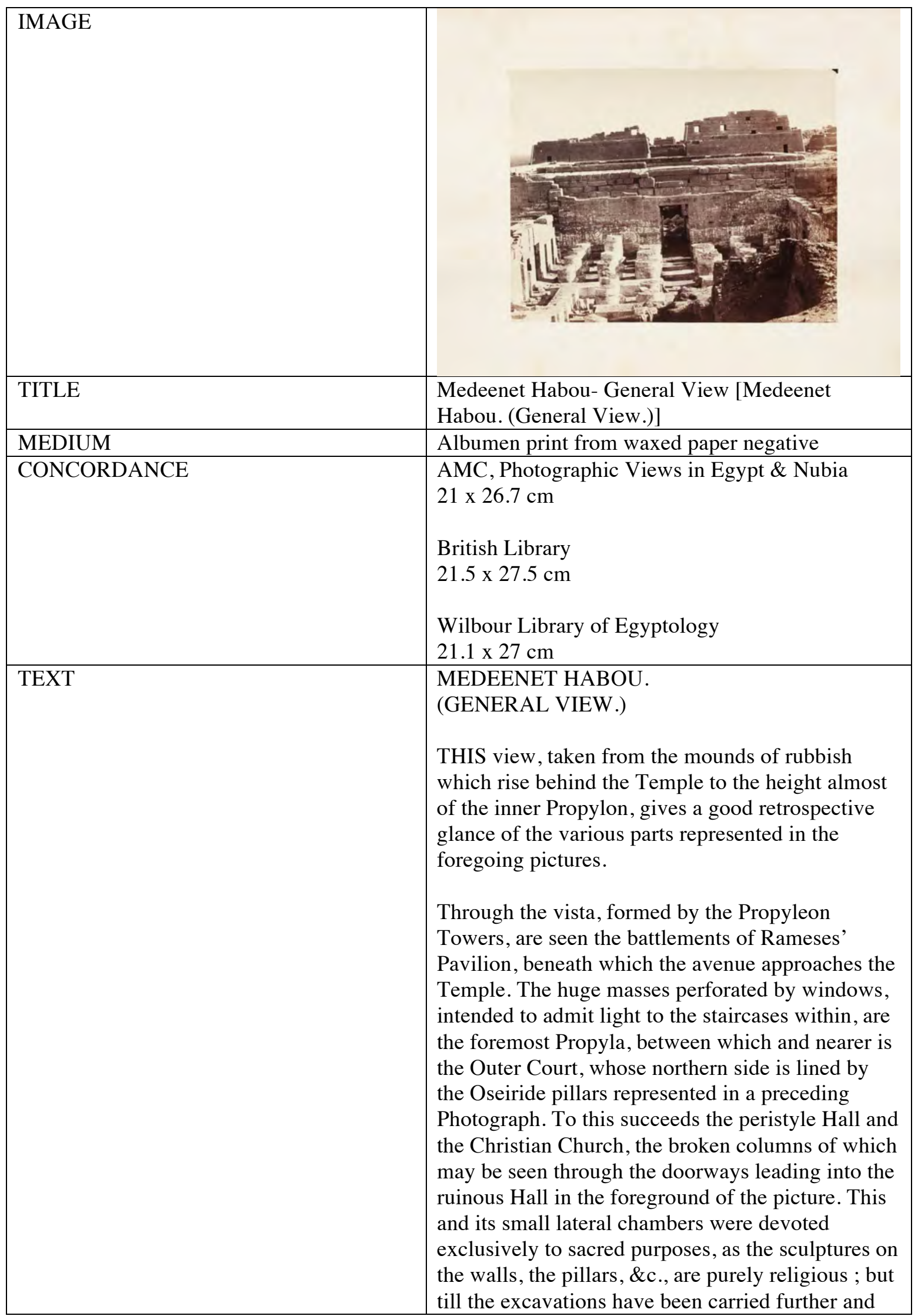




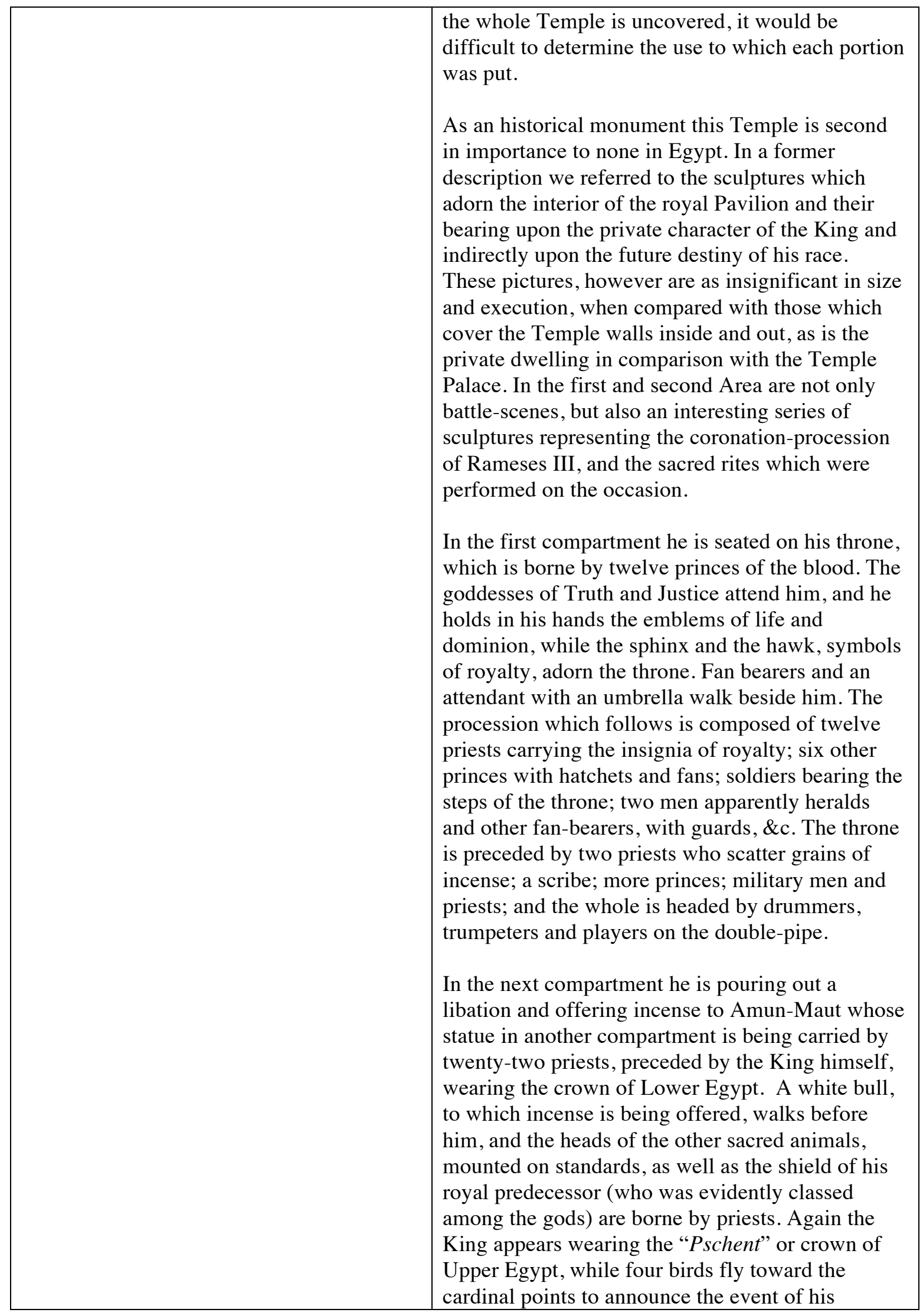




\begin{tabular}{|l|l|}
\hline coronation. \\
$\qquad \begin{array}{l}\text { In the last compartment the King, who has laid } \\
\text { aside his crown and wears a helmet, cuts with a } \\
\text { sickle six ears of corn which a priest offers to the } \\
\text { sacred bull; a ceremony emblematic probably of } \\
\text { the relation between the kingly office and } \\
\text { agriculture, and performed in honour of the god } \\
\text { Amun-Khem, who symbolized the productive } \\
\text { powers of nature. }\end{array}$ \\
$\begin{array}{ll}\text { Exciting battle-scenes by sea and land, conceived } \\
\text { with as much spirit and executed as artistically as } \\
\text { those of the Rameseum, are likewise represented, } \\
\text { and on the northern wall is depicted, with } \\
\text { admirable fidelity and power, a lion hunt. }\end{array}$ \\
\begin{tabular}{ll} 
J.D., JR. \\
\hline NOTES
\end{tabular} & $\begin{array}{l}\text { Image from AMC, Photographic Views in Egypt \& } \\
\text { Nubia. }\end{array}$ \\
\hline
\end{tabular}

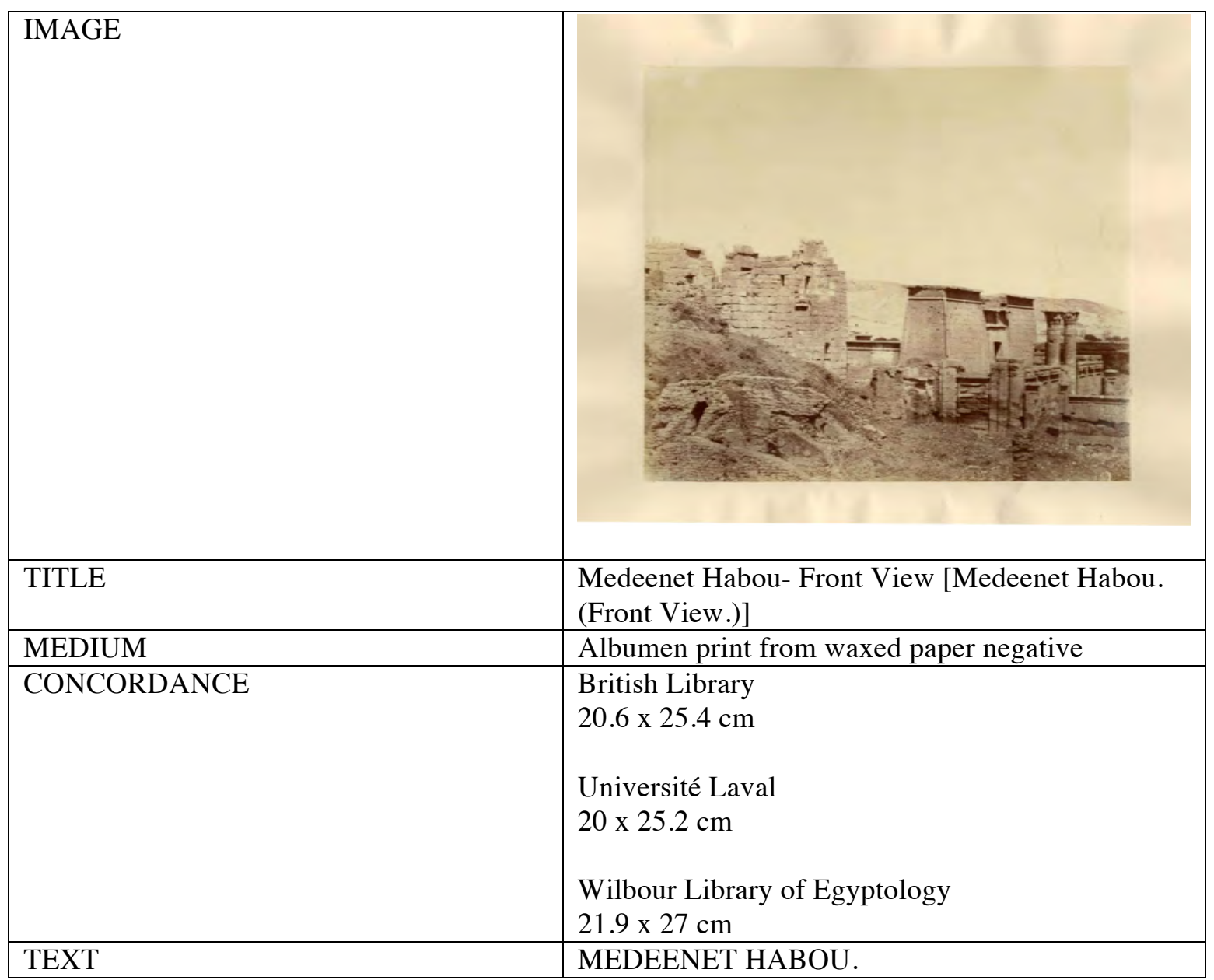




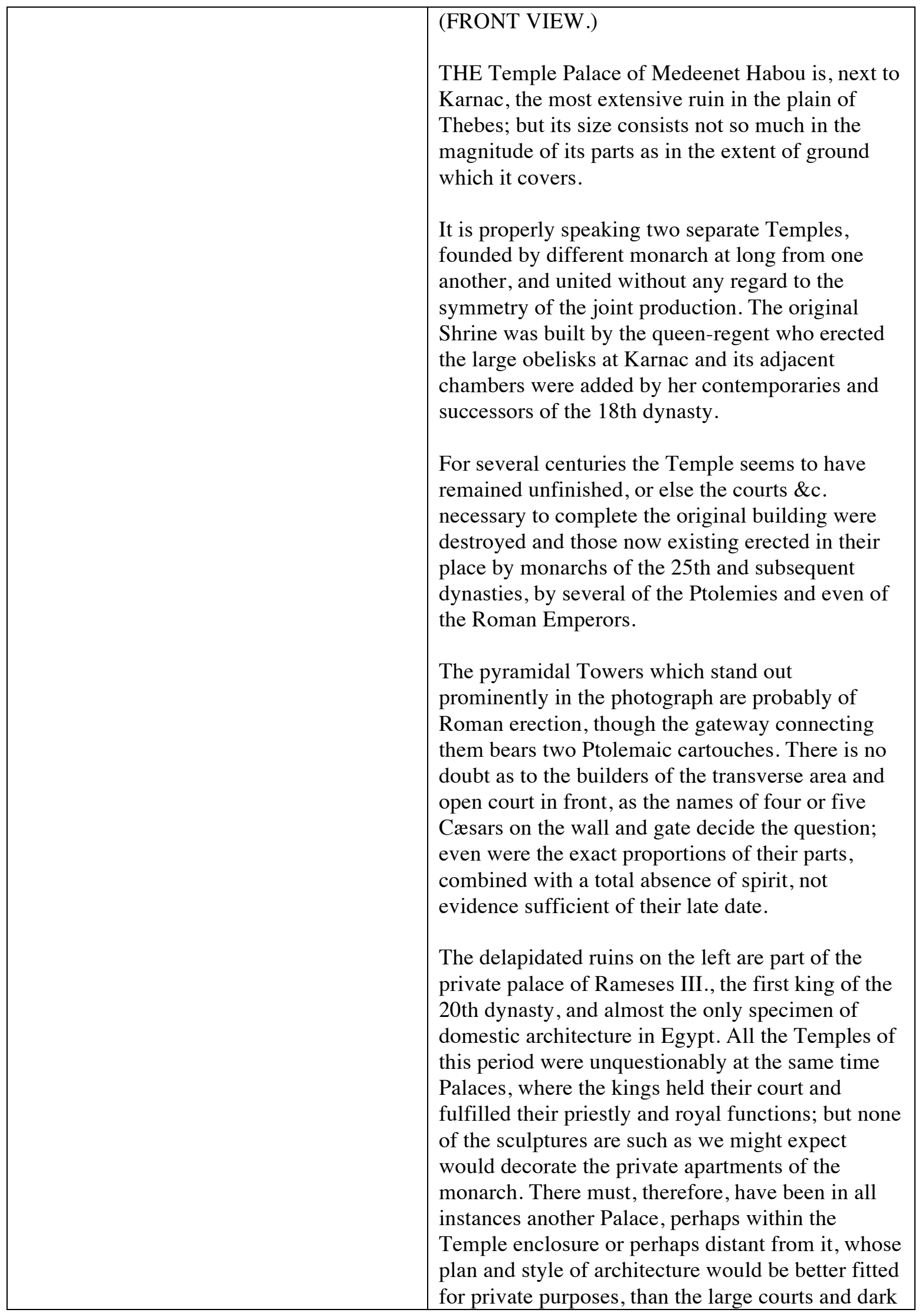




\begin{tabular}{|c|c|}
\hline & $\begin{array}{l}\text { chambers of the Temple. Their disappearance in } \\
\text { every case but this may be easily accounted for by } \\
\text { the different mode of their construction, which } \\
\text { would be less massive and lofty. That the } \\
\text { Egyptians understood too well the true principles } \\
\text { of art, which views every thing in conjunction with } \\
\text { its intended use, to employ the monumental style } \\
\text { of architecture, with its unbroken lines and } \\
\text { enormous masses in domestic building, this Palace } \\
\text { affords unquestionable proof. } \\
\text { The entrance to the Temple behind was through } \\
\text { this Pavilion. Its plan is therefore awkward and the } \\
\text { rooms by no means spacious. It was built in two } \\
\text { stories, the floor line being marked in places by a } \\
\text { cornice. The windows vary in size and design, and } \\
\text { the external decorations of the walls are } \\
\text { ununiform. Their lines all slope inward, as was } \\
\text { invariably the case in the Temples, but a graceful } \\
\text { battlement of inverted Egyptian shields surmounts } \\
\text { them. What lends peculiar interest to this building } \\
\text { are the sculptures which adorn the interior. These } \\
\text { represent the king enjoying the society of his } \\
\text { harem, and are of such a nature as to explain the } \\
\text { ignominious termination of his reign which began } \\
\text { so brilliantly, and the rapid decay of his race, } \\
\text { which though it still sat for generations upon the } \\
\text { throne of Egypt, seems never to have resumed its } \\
\text { natural powers and glory, so fatally impaired by its } \\
\text { founder. } \\
\text { J.D., JR. }\end{array}$ \\
\hline NOTES & Image courtesy of Université Laval. \\
\hline
\end{tabular}

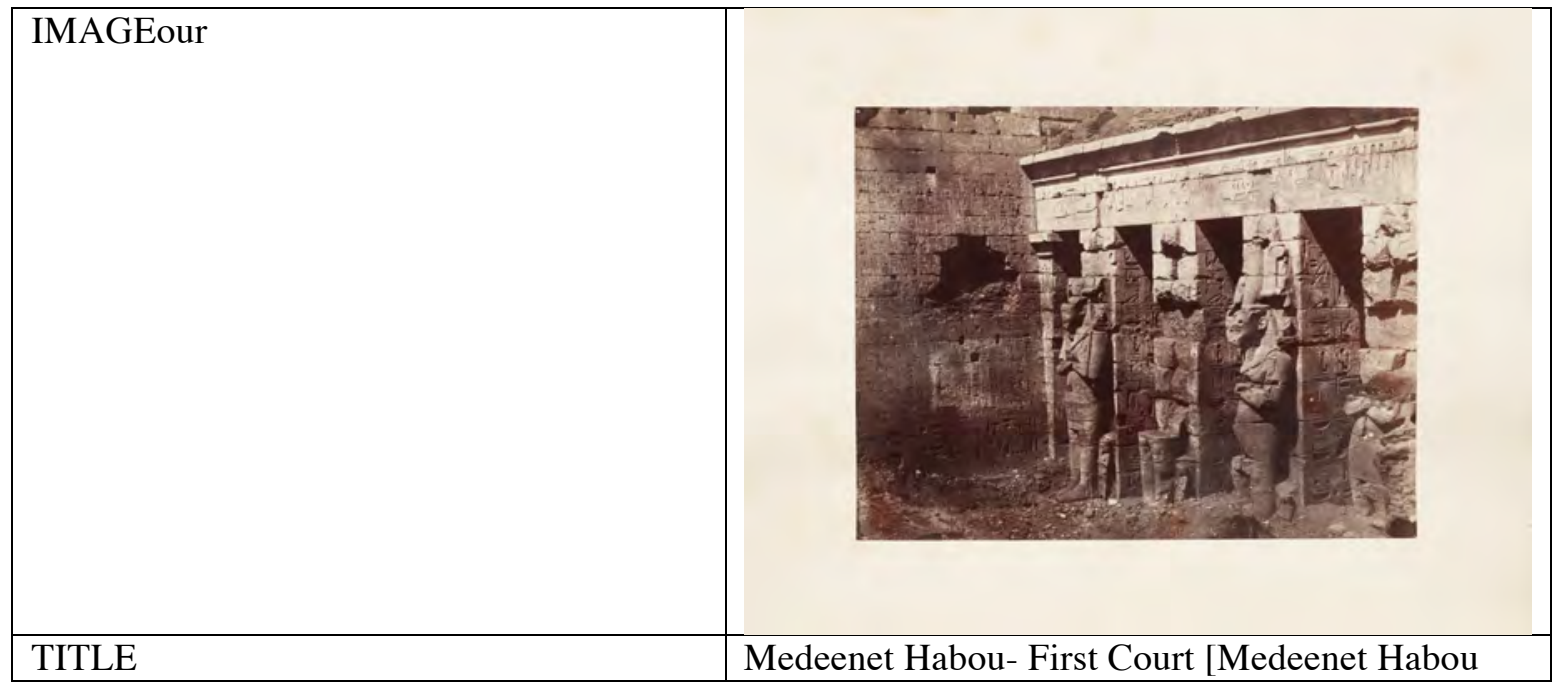




\begin{tabular}{|c|c|}
\hline & (First Court)] \\
\hline MEDIUM & Albumen print from waxed paper negative \\
\hline CONCORDANCE & $\begin{array}{l}\text { AMC, Photographic Views in Egypt \& Nubia } \\
20.9 \times 26.8 \mathrm{~cm} \\
\text { British Library } \\
20.8 \times 27.5 \mathrm{~cm} \\
\text { Wilbour Library of Egyptology } \\
21.7 \times 27 \mathrm{~cm}\end{array}$ \\
\hline TEXT & $\begin{array}{l}\text { MEDEENET HABOU. } \\
\text { (FIRST COURT.) } \\
\text { AFTER passing through the private Palace, a } \\
\text { Dromos of Sphinxes form an avenue two hundred } \\
\text { and sixty-five feet long to the Pylon which admits } \\
\text { to the main building. The outer Court, in which the } \\
\text { view is taken, exhibits one of the most extravagant } \\
\text { instances of what has been termed } \\
\text { symmetrophobia. On one side it is lined by a row } \\
\text { of piers with Oseiride figures, on the other by eight } \\
\text { columns with bell-shaped capitals. If this } \\
\text { intentional disregard of regularity sprang from a } \\
\text { dread of monotony it was right in principle, but the } \\
\text { Egyptians undoubtedly often carried it beyong the } \\
\text { limits of good taste. One is more inclined to } \\
\text { attribute such deviation from the most fundamental } \\
\text { rules of art and which were well understood by } \\
\text { them, to the caprice of the royal builder, who on } \\
\text { one occasion carried his whim so far as to invert } \\
\text { the capitals of his pillars and convert an imposing } \\
\text { into a ludicrous effect. } \\
\text { The figures attached to the piers which support one } \\
\text { of the corridors of this Hall, were, no doubt, } \\
\text { likenesses of the king who built the Temple. On his } \\
\text { head he wears the head-dress of the god Phtah- } \\
\text { Sokkari, and in his hands holds the attributes of } \\
\text { Oseiris. } \\
\text { This peculiar form of pillar was a favourite with } \\
\text { the builder of this Temple and the great Rameses, } \\
\text { as it occurs only once except in their works. The } \\
\text { earliest instance of it is in the colonnade built } \\
\text { around the Shrine of Osirtasen by Thothmes I. It is } \\
\text { thrice found among the Temples of Rameses II, - } \\
\text { in the second Court of the Rameseum, and at the } \\
\text { Gerf Hossayn and Abou Simbel, both rock temples } \\
\text { in Nubia; and it decorates this Court and the next } \\
\text { Hall of this Temple. }\end{array}$ \\
\hline
\end{tabular}




\begin{tabular}{|c|c|}
\hline & $\begin{array}{l}\text { It cannot properly be considered a separate style, } \\
\text { nor does it correspond to the Caryatide column of } \\
\text { the Ionic order, as the figure is only attached to the } \\
\text { pillar and bears none of the weight; whereas the } \\
\text { Caryatidæ of the Erechtheum and other Greek } \\
\text { buildings themselves supply the place of columns } \\
\text { and support the entablature or some other } \\
\text { architectural part. The propriety of their use in } \\
\text { Greek architecture has with justice been } \\
\text { questioned, but the employment of Oseiride figures } \\
\text { in Egyptian is strictly consistent with its spirit and } \\
\text { purpose. As they were intended to be likenesses of } \\
\text { the kind who erected them, they must be classes } \\
\text { with the colossi, sphinxes and other detached but } \\
\text { not less important and intrinsic parts of the } \\
\text { Egyptian Temple, which was in the most literal } \\
\text { sense a monument erected by the king to his own } \\
\text { praise and honour, though dedicated to a god, from } \\
\text { whom he professed to have received his courage } \\
\text { and strength, and whom he made responsible } \\
\text { therefore for all his barbarities. } \\
\text { This view affords us likewise a good example of } \\
\text { the important use made of the hieroglyphic } \\
\text { symbols in Egyptian architecture, which by } \\
\text { associating with itself sculpture, painting and } \\
\text { pictorial writing in one indissoluble union, } \\
\text { produced its gorgeous effects in endless variety } \\
\text { with but limited architectural materials. As this } \\
\text { court is bounded on both the N.W. and S.E. sides } \\
\text { by massive towers, the impressive effect which it } \\
\text { was intended they should produce would have } \\
\text { been destroyed had a colonnade been attached; } \\
\text { while at the same time their bare walls would have } \\
\text { been unsightly. To remedy this the eye is relieved } \\
\text { by the graceful and beautifully cut hieroglyphics, } \\
\text { which at the same time are as significant as the } \\
\text { sculptures which adorn other parts. But } \\
\text { hieroglyphs and religious symbols fill up not only } \\
\text { such vacant spaces, but completely cover every } \\
\text { portion, as, in this instance, the square piers, the } \\
\text { architrave and the cornice. } \\
\end{array}$ \\
\hline NOTES & $\begin{array}{l}\text { Image from AMC, Photographic Views in Egypt \& } \\
\text { Nubia. }\end{array}$ \\
\hline
\end{tabular}




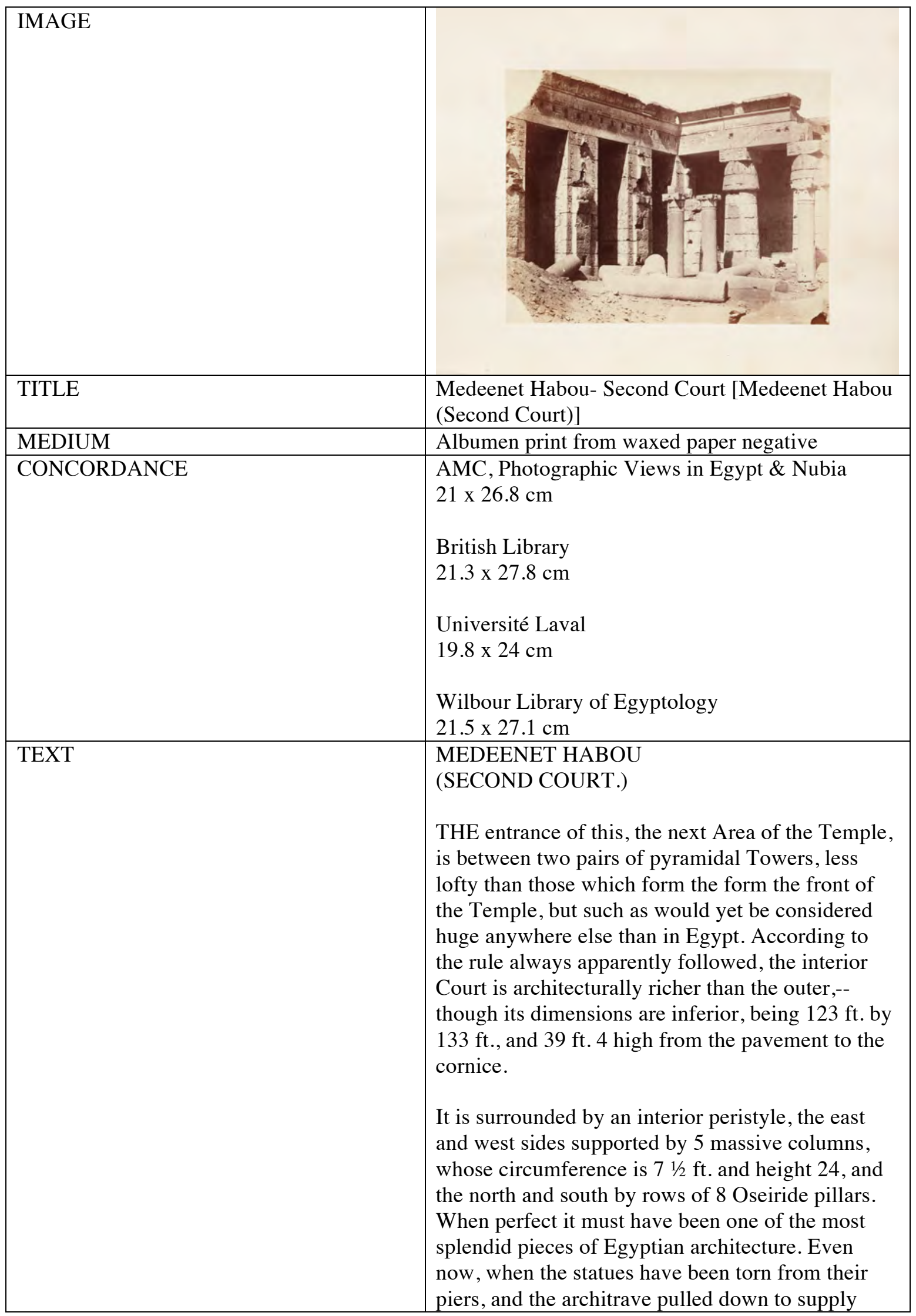




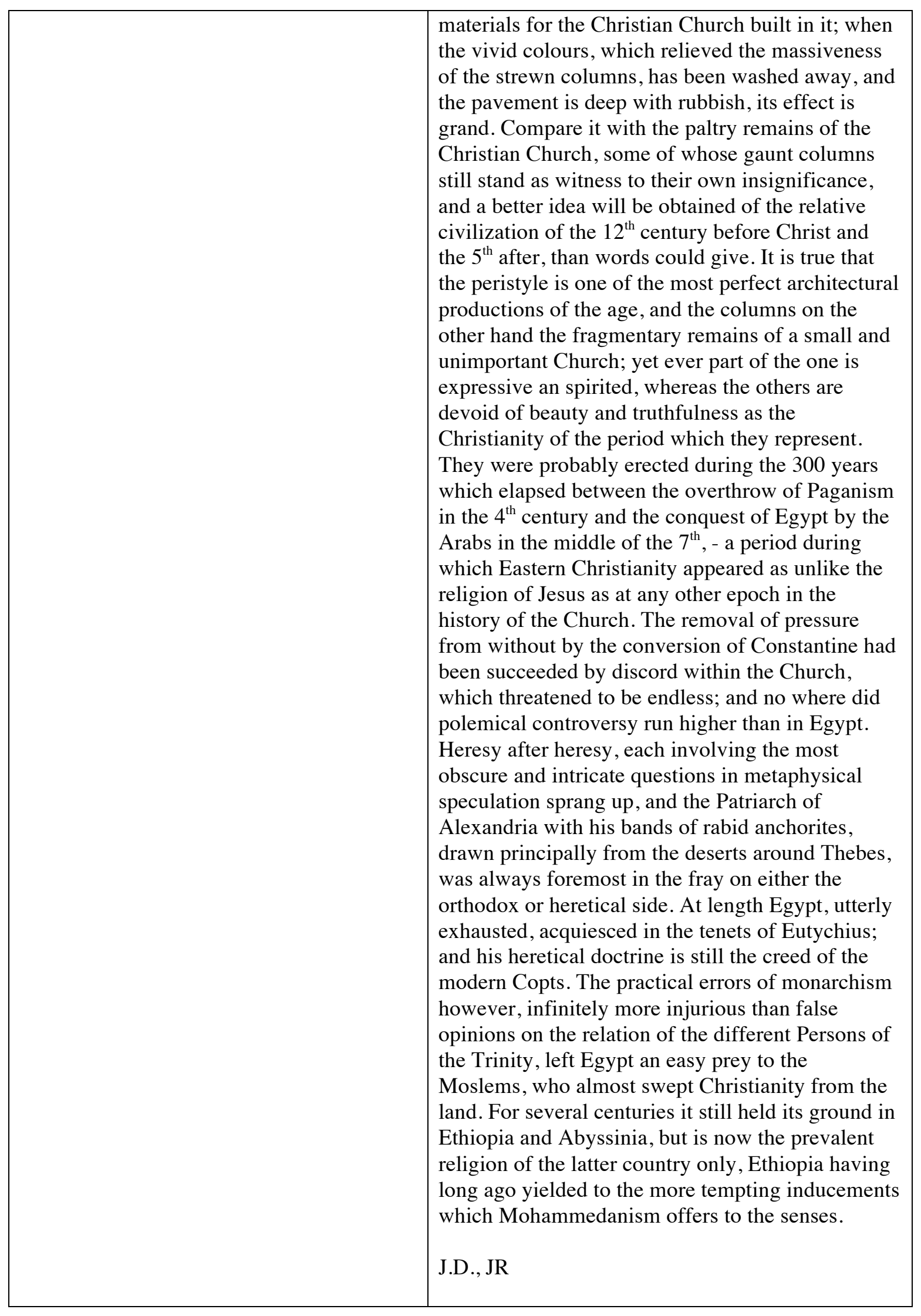




\begin{tabular}{|l|l|}
\hline & \\
\hline NOTES & $\begin{array}{l}\text { Image from AMC, Photographic Views in Egypt \& } \\
\text { Nubia. }\end{array}$ \\
\hline
\end{tabular}

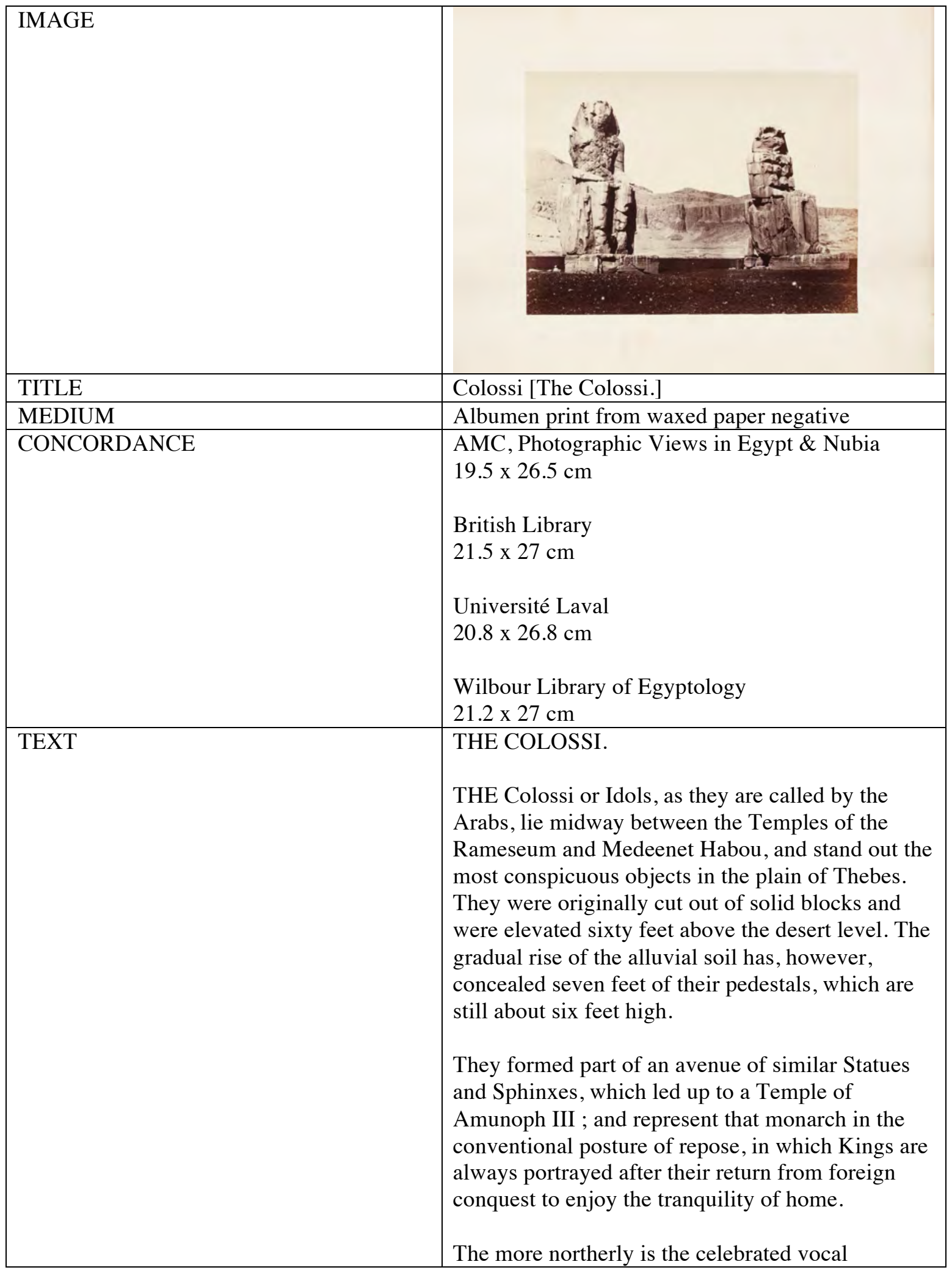




\begin{tabular}{|c|c|}
\hline & $\begin{array}{l}\text { Memnon, which used to greet the rising sun with } \\
\text { its sweet morning song. The upper part was long } \\
\text { ago mutilated, some say by Cambyses, and } \\
\text { repaired by four layers of large stones; but the } \\
\text { earlier destruction of its vocal organs, lungs and } \\
\text { all, not only did not interrupt its singing, but seems } \\
\text { to have first called it forth, as there is no tradition } \\
\text { of its being vocal till the latest eras of Egyptian } \\
\text { history. It became silent again before the } \\
\text { overthrow of paganism, as none of the ancient } \\
\text { inscriptions, scratched by travellers on the } \\
\text { pedestal, are of later date than the reign of } \\
\text { Septimius Severus. The phenomenon is easily } \\
\text { accounted for: in the lap of the Statue is still found } \\
\text { a slab of fine grained sandstone, so poised that, } \\
\text { when stuck, it emits a clear metallic sound; a pries, } \\
\text { hidden in the body, might easily produce the } \\
\text { desired effect without discovery. On either side of } \\
\text { each of the legs of the large Statues are small } \\
\text { standing figures and still smaller ones between } \\
\text { them. } \\
\text { Fragments of other Colossi of equal size are found } \\
\text { near by, and the foundations of part of the Temple } \\
\text { to which they led, had been discovered shortly } \\
\text { before our visit. } \\
\text { This Temple was no doubt built to correspond in } \\
\text { position with the large Temple Palace of Luxor, } \\
\text { founded by the same monarch on the opposite side } \\
\text { of the Nile; and between them, as an interesting } \\
\text { historical Papyrus, found some years ago, informs } \\
\text { us, lay the principal street of Thebes; by which we } \\
\text { shall now proceed to the Temples on the eastern } \\
\text { bank. } \\
\text { J.D., JR. }\end{array}$ \\
\hline NOTES & $\begin{array}{l}\text { Image from AMC, Photographic Views in Egypt \& } \\
\text { Nubia. }\end{array}$ \\
\hline
\end{tabular}




\begin{tabular}{|c|c|}
\hline IMAGE & \\
\hline TITLE & Luxor [Luxor] \\
\hline MEDIUM & Albumen print from waxed paper negative \\
\hline CONCORDANCE & $\begin{array}{l}\text { British Library } \\
21.3 \times 27.3 \mathrm{~cm} \\
\text { Wilbour Library of Egyptology } \\
21.7 \times 26.3 \mathrm{~cm}\end{array}$ \\
\hline TEXT & $\begin{array}{l}\text { LUXOR } \\
\text { IS situated on the E. bank of the Nile and close to } \\
\text { the water's edge. Unlike most of the Temples in } \\
\text { Egypt which preserve their ancient character, and } \\
\text { which consequently gives them their greatest } \\
\text { charm and interest, Luxor is surrounded, partly } \\
\text { covered, and in a great measure filled by native } \\
\text { mud houses. If these were swept away and the sand } \\
\text { and rubbish removed down to the original level of } \\
\text { the Temple, Luxor would again appear as one of } \\
\text { the most remarkable and interesting remains in } \\
\text { Egypt. } \\
\text { From the remaining obelisk, which stands in front } \\
\text { of the principal gateway, to the extreme back wall } \\
\text { is about one thousand feet, its width is about two } \\
\text { hundred feet. Its plan and construction are similar } \\
\text { to Egyptian Temples generally. In front were two } \\
\text { obelisks of red granite erected and beautifully } \\
\text { carved by Rameses II, immediately behind them } \\
\text { and on each side of the entrance were two colossal } \\
\text { figures at the same monarch, in the usual } \\
\text { conventional sitting position. The front of the } \\
\text { propyleon towers were elaborately sculptured with } \\
\text { representations of battle scenes. The whole of } \\
\text { these, however, obelisks, statues and towers have } \\
\text { been buried to a depth of some twenty feet by the } \\
\text { accumulation of drifted sand and rubbish. The }\end{array}$ \\
\hline
\end{tabular}




\begin{tabular}{|c|c|}
\hline & $\begin{array}{l}\text { great area, within the entrance, is now filled by the } \\
\text { mosque and native houses; among these may still } \\
\text { be seen the rows of pillars which surrounded it, } \\
\text { and the head and part of the bust of a colossal } \\
\text { figure. Behind this, again, is the grand colonnade; } \\
\text { the columns are very stately and very beautifully } \\
\text { sculptured; they are } 36 \text { feet in circumference and } \\
\text { about } 40 \text { feet in height. Beyond this the different } \\
\text { parts of the original Temple are so filled up with } \\
\text { modern houses, as to be with difficulty made out. } \\
\text { Mustapha Aga the British and American Vice- } \\
\text { Consul has fitted up some of the chambers for } \\
\text { himself and his harem. One large one has been } \\
\text { fitted up for the American Missionary, the Revd. } \\
\text { Mr. Lansing and his wife. Others have been fitted } \\
\text { up and added to for the French Vice-Consul, some } \\
\text { are used as stables, and one in the adytum or } \\
\text { sanctuary contained two very fine pigs, the } \\
\text { property of the French Vice-Consul. It is a pity to } \\
\text { see so magnificent a specimen of an Egyptian } \\
\text { Temple so obscured by moderns, particularly by } \\
\text { English and French; it is the greatest pity as Luxor, } \\
\text { perhaps more than any other Temple, shews the } \\
\text { gradual decadence of art from the time of the } 18 \text { th } \\
\text { dynasty to the late Roman period. In one chamber, } \\
\text { at the south of the Temple, one of the Cæsars is } \\
\text { represented dressed in the Roman toga; the } \\
\text { attitude, the figure and the costumes were not only } \\
\text { out of keeping with every thing else in the Temple, } \\
\text { but to me appeared perfectly hideous. } \\
\text { J.D. }\end{array}$ \\
\hline NOTES & $\begin{array}{l}\text { Image from Brooklyn Museum Libraries. Wilbour } \\
\text { Library of Egyptology, Special Collections. }\end{array}$ \\
\hline
\end{tabular}

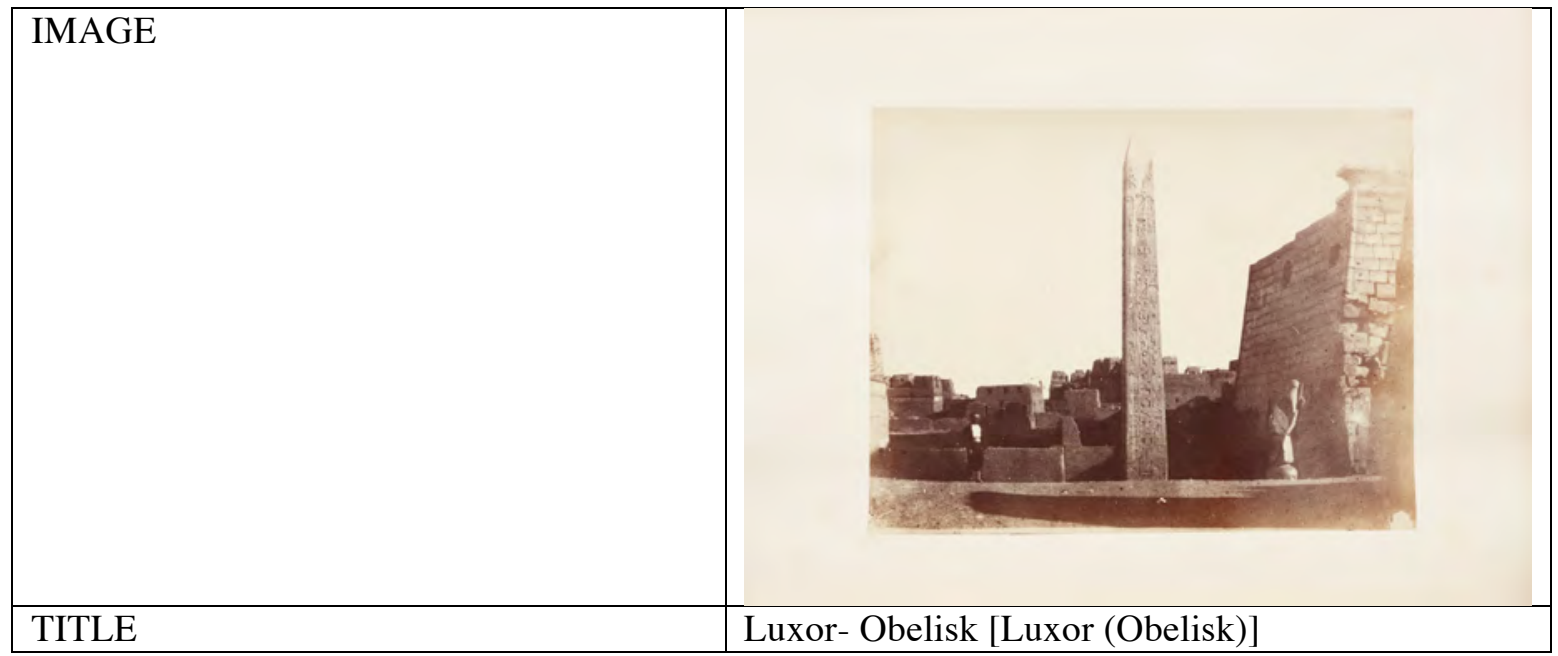




\begin{tabular}{|c|c|}
\hline MEDIUM & Albumen print from waxed paper negative \\
\hline CONCORDANCE & $\begin{array}{l}\text { AMC, Photographic Views in Egypt \& Nubia } \\
21.2 \times 27 \mathrm{~cm} \\
\text { British Library } \\
21.3 \times 27.3 \mathrm{~cm} \\
\text { Université Laval } \\
21.7 \times 27.7 \mathrm{~cm} \\
\text { Wilbour Library of Egyptology } \\
21.7 \times 27 \mathrm{~cm}\end{array}$ \\
\hline TEXT & $\begin{array}{l}\text { LUXOR. } \\
\text { (OBELISK.) } \\
\text { THIS beautiful Obelisk with its mate terminated } \\
\text { the avenue of Sphinxes which connected the } \\
\text { Temple of Luxor with that of Karnac, and admitted } \\
\text { to another magnificent Temple Palace of the } 18^{\text {th }} \\
\text { and } 19^{\text {th }} \text { Dynasties. } \\
\text { The Sanctuary and adjacent chambers, a large } \\
\text { Colonnade and a Pylon were built by Amunoph II, } \\
\text { but the Propyleon Towers and colossal Statues, the } \\
\text { heads and shoulders of which are now alone above } \\
\text { ground, and the Obelisks, were erected by } \\
\text { Rameses II. On the Towers are some spirited battle } \\
\text { scenes, and the Statues were apparently as } \\
\text { beautiful as any in Egypt, though far from as large } \\
\text { as either the "Colossi of the Plain" or that in the } \\
\text { Court of the Rameseum. Nothing, however, exists } \\
\text { in Egypt more perfect than this Obelisk. Its four } \\
\text { faces are covered with a profusion of well arranged } \\
\text { and deeply cut hieroglyphics; and it is remarkable } \\
\text { that each face is slightly grooved, the object being } \\
\text { to throw out the hieroglyphs more distinctly that if } \\
\text { the rays of the sun fell on a flat surface. } \\
\text { Its fellow now stands in the Place de la Concorde, } \\
\text { in Paris, having been removed by Louis Philippe as } \\
\text { a trophy of the French occupation of Egypt. Sir G. } \\
\text { Wilkinson, who was present when it was taken } \\
\text { down, observed, "that beneath the lower end, that } \\
\text { on which it stood, were sculptured the nomen and } \\
\text { prenomen of Rameses, and that a crack which had } \\
\text { been discovered before its erection had been } \\
\text { secured by two wooden dove-tailed cramps." } \\
\text { Where it stood it was in keeping with all around it, } \\
\text { where it now stands it appears like a stranger in a } \\
\text { foreign land. Unfortunately most of the Obselisks }\end{array}$ \\
\hline
\end{tabular}




\begin{tabular}{|l|l|}
\hline & $\begin{array}{l}\text { of Egypt have shared with the same fate, having } \\
\text { been carried away to uncongenial climates by } \\
\text { conquerors, who were actuated by much the same } \\
\text { motives as those who erected them, but guided by } \\
\text { far worse taste. There are now in Egypt only six } \\
\text { entire Obelisks: two at Alexandria, the one } \\
\text { standing, the other fallen. They were transported } \\
\text { from Heliopolis by one of the Cæasars and are } \\
\text { commonly known by the name of Cleopatra's } \\
\text { Needles. The magnificent Obelisk of Osirtasen II, } \\
\text { at Heliopolis has never been disturbed; two only of } \\
\text { the four Obelisks of Karnac are still erect, and the } \\
\text { Obelisk of Luxor completes the number. Rome and } \\
\text { Constantinople can boast of possessing more } \\
\text { Egyptian Obelisks than Egypt itself. }\end{array}$ \\
& J.D., JR. \\
\hline NOTES & $\begin{array}{l}\text { Image from AMC, Photographic Views in Egypt } \& \\
\text { Nubia. }\end{array}$ \\
\hline
\end{tabular}

\begin{tabular}{|l|l|}
\hline IMAGE & \\
& \\
& \\
\hline TITLE & \\
\hline MEDIUM & \\
\hline CONCORDANCE & Luxor- Mustapha Aga [Luxor (Mustapha Aga)] \\
& Albumen print from waxed paper negative \\
& AMC, Photographic Views Taken in Egypt \\
& $21.2 \times 28.2 \mathrm{~cm}$ \\
& British Library \\
$21.4 \times 26.2 \mathrm{~cm}$ \\
\hline TEXT & Université Laval \\
$21.8 \times 28 \mathrm{~cm}$ \\
Wilbour Library of Egyptology \\
$21.9 \times 27 \mathrm{~cm}$ \\
\hline
\end{tabular}




\section{(MUSTAPHA AGA.)}

SEATED on a chair, in front of the colonnade of the Temple, with the whole of his family, excepting his wives, seated or standing around him. Mustapha himself may be considered as one of the institutions of Thebes. He is now about fifty years of age, is dark in complexion, of Bedouin extraction, speaks tolerably good English, is greedy, grasping and unscrupulous, yet, among the Arabs, sustains a high character for hospitality and openhandedness. When a young man, he made a voyage to England and to India, in the forecastle of a man-of-war; he returned to Alexandria with the knowledge of English and of the world peculiar to that school, and with the loss of a great part of his religion and of his nose. His peculiar fitness and education adapted him for service in a Marine Store, where he served for some years, at first as servant, and latterly as partner. He, by some means, obtained the situation of Titular British Vice-Consul at Thebes, which, although it yielded no salary, places him in official relation to all English Travellers there, and gives him great influence among the Arabs. He took up his abode in some of the deserted chambers of the Temple of Luxor, hoists his flag from the roof, fires a gun on the arrival and departure of an English boat, and pays his respects with an offering of a sheep, some fowls, or vegetables. He is profuse in his offers of assistance.

$\mathrm{He}$, however, causes it to be understood that as he receives no salary, it is customary to make him a liberal present. He generally fixes upon something which he either sees in the Dahabieh, or which he finds out that you possess, and travellers often find it difficult to resist his attacks, particularly, if they have accepted his initiatory offering. He deals in antiquities of all kinds, a few years ago he dealt through a Copt in the village, and through a couple of Arabs, who resided in the Tombs at Sheik Abd el Goorneh. On my first visit, Mustapha, as usual paid his respects, and sent a present of a Sheep. I at once sent the Dragoman to say that I neither received or gave present, and to pay for the Sheep. This put us on fair footing, both then and for the future. A day or two afterwards when we formally returned his visit, he asked: "Do you want any antiquity, or have you seen anything you want?" I 


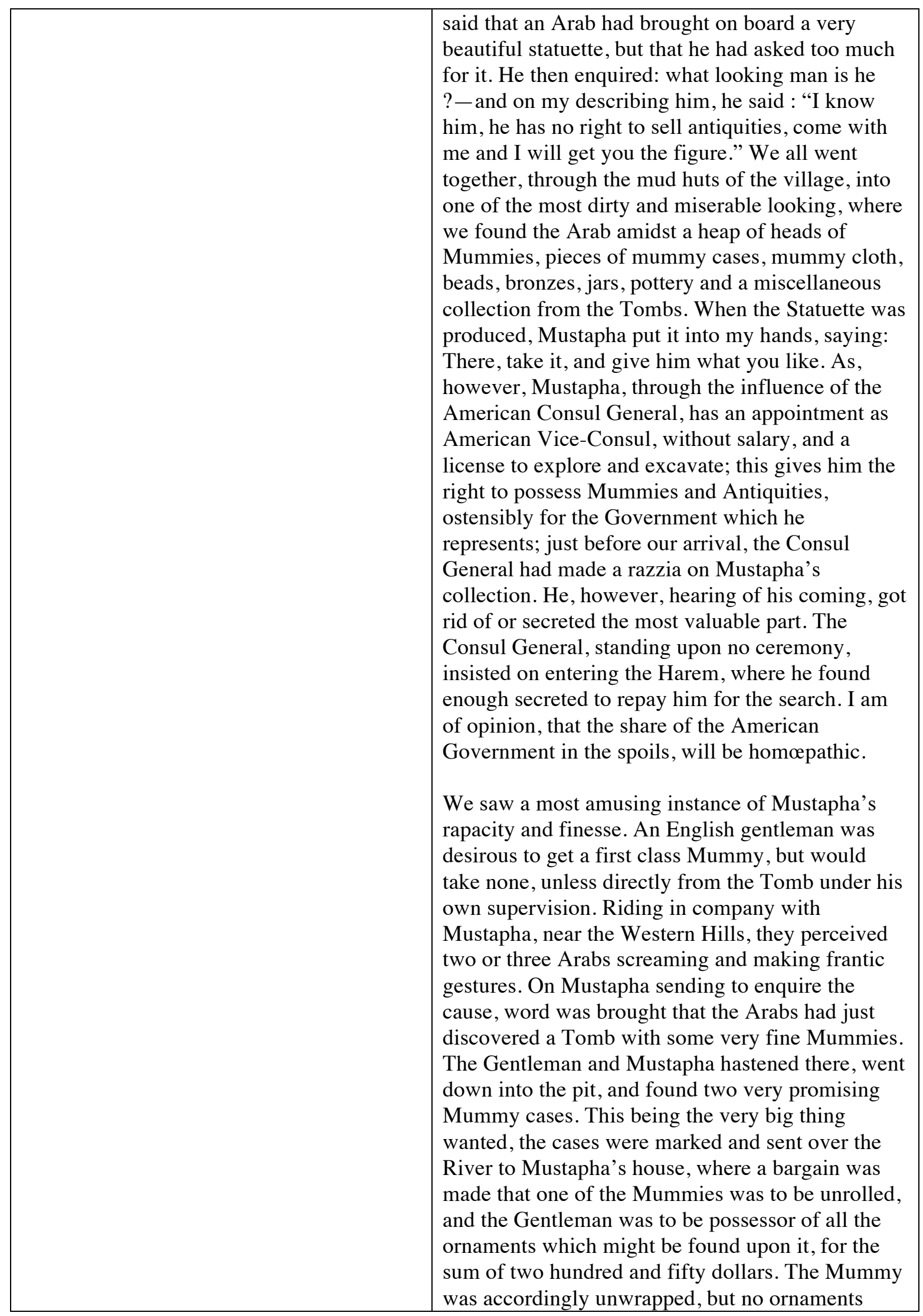




\begin{tabular}{|l|l|}
\hline & $\begin{array}{l}\text { were found, excepting a gilt winged Scarabeus } \\
\text { upon the breast, which might have been purchased } \\
\text { from an Arab resurrectionist for two shillings. To } \\
\text { compensate in some degree for the } \\
\text { disappointmnent, Mustapha consented to allow the } \\
\text { other Mummy to be unwrapped on the same } \\
\text { conditions for one hundred dollars; this was agreed } \\
\text { to, the Mummy was forthwith unbandaged, and } \\
\text { found to possess nothing whatever. The first } \\
\text { Mummy unwrapped was certainly a very good one, } \\
\text { and its double cases were very good. During my } \\
\text { last visit, I obtained a finer one, in double cases, } \\
\text { for Mr. Barnett, of Niagara Museum, for seven } \\
\text { pounds. }\end{array}$ \\
$\begin{array}{ll}\text { The Copt manufactures Scaraboi and collects } \\
\text { antiques under the protection of the Danish } \\
\text { Consul; he is not to be trusted. Mustapha collects } \\
\text { under the wing of the American Consul, and will } \\
\text { assuredly cheat you if he can. Upon the whole, I } \\
\text { think that the Copt is the most respectable rascal of } \\
\text { the two. }\end{array}$ \\
J.D. \\
\hline NOTES \\
$\begin{array}{l}\text { Image from AMC, Photographic Views Taken in } \\
\text { Egypt. }\end{array}$ \\
\hline
\end{tabular}

\begin{tabular}{|l|l|}
\hline IMAGE & \\
& \\
& \\
& \\
\hline TITLE & \\
\hline MEDIUM & \\
\hline CONCORDANCE & Karnac- General View [Karnac. (General View.)] \\
\hline & Albumen print from waxed paper negative \\
\hline & $21.5 \times 27.7 \mathrm{~cm}$ \\
\hline & British Library \\
& $21.4 \mathrm{x} 26.8 \mathrm{~cm}$ \\
\hline
\end{tabular}




\begin{tabular}{|c|c|}
\hline & $\begin{array}{l}\text { Wilbour Library of Egyptology } \\
21.2 \times 27 \mathrm{~cm}\end{array}$ \\
\hline TEXT & $\begin{array}{l}\text { KARNAC. } \\
\text { (GENERAL VIEW.) } \\
\text { THE ruins of Karnac are among the grandest in the } \\
\text { world, if indeed they are not unsurpassed by an in } \\
\text { size and magnificence. The first Shrine was built } \\
\text { by Osirtasen II., the renowned ruler of the } 12^{\text {th }} \\
\text { Dynasty, and was held in such peculiar reverence } \\
\text { by his successors of the new Empire, that some of } \\
\text { its broken columns of the same proto-Doric order } \\
\text { as support the tombs of Beni Hassan, which were } \\
\text { excavated in his reign, are still found. During the } \\
\text { dark period of the Hyksos supremacy, when the } \\
\text { Theban race of princes was reduced to a state of } \\
\text { vassalage, nothing appears to have been added; } \\
\text { though more respect was here shown to what } \\
\text { already existed than in Lowe Egypt, where their } \\
\text { power was probably more absolute. } \\
\text { As soon however as their yoke was thrown off, the } \\
\text { royal race religiously turned to the Shrine of their } \\
\text { glorious Ancestors and each successive monarch } \\
\text { made some addition, which should vie in splendor } \\
\text { with the work of his forefathers. Thus Karnac } \\
\text { became the national monument, and in process of } \\
\text { time, grew to such a size that its enclosure measure } \\
\text { one mile and three quarters in circumference. } \\
\text { The portions contributed by the } 18^{\text {th }} \text { and } 19^{\text {th }} \\
\text { Dynasties, the Dynasties with which the new } \\
\text { Empire commenced, bear some relation to one } \\
\text { another and the original Sanctuary; but soon the } \\
\text { Temple possessed all its necessary parts, and then } \\
\text { produced their imposing effects by the most } \\
\text { obvious means, by the employment of huge masses } \\
\text { and a display of immense constructive strength; } \\
\text { side by side with the mighty acts of their ancestors } \\
\text { on the stony pages of their great national annals, } \\
\text { (for such were all the large Theban temples,) were } \\
\text { obliged either to erect some meaningless } \\
\text { monument within the Temple walls or to add other } \\
\text { Temples, as wings to the original building, though } \\
\text { quite distinct from it, and complete in themselves. } \\
\text { By this means Karnac became the most irregular of } \\
\text { the unsymetrical Temples of Egypt. }\end{array}$ \\
\hline
\end{tabular}




\begin{tabular}{|c|c|}
\hline & $\begin{array}{l}\text { and disregarded to a great extent-though they } \\
\text { were by no means ignorant of - the rules of } \\
\text { proportion; as moreover they never availed } \\
\text { themselves of external peristyles and but sparingly } \\
\text { of architectural ornaments, these additions to the } \\
\text { original structure, which in any other class of } \\
\text { buildings would have utterly ruined the whole, } \\
\text { increased, if anything, the effect. The genius of } \\
\text { Egyptian architecture was in this, as in almost } \\
\text { every other respect, directly opposed to the Greek, } \\
\text { in which gracefulness of form and minute regard to } \\
\text { proportion were everything. It would have been } \\
\text { impossible to add to the buildings of the Periclean } \\
\text { age without altogether marring their beauty, yet so } \\
\text { little did the Egyptian architect rely upon exact } \\
\text { relative proportions, that such excrescences as } \\
\text { those which grew out of the temple of Karnac are } \\
\text { not felt to be faults, though far inferior in size to } \\
\text { the main building; and such total disregard of } \\
\text { symmetry reigns throughout even their most } \\
\text { magnificent productions, that the axis of many of } \\
\text { their Temples is not the same throughout, and the } \\
\text { intercolumnar distance in corresponding rows of } \\
\text { pillars in the same hall varies. Yet these departures } \\
\text { from regularity never shock the eye as far minor } \\
\text { faults of the same character in a Greek structure } \\
\text { would, because they are not felt to be inconsistent } \\
\text { with the pervading idea of the architecture, nor to } \\
\text { have been errors on the part of the architect. } \\
\text { J.D., JR. }\end{array}$ \\
\hline NOTES & $\begin{array}{l}\text { Image from AMC, Photographic Views Taken in } \\
\text { Egypt. Université Laval album has the text from } \\
\text { "Karnac- General View" paired with the image } \\
\text { "Karnac- From the East". }\end{array}$ \\
\hline
\end{tabular}




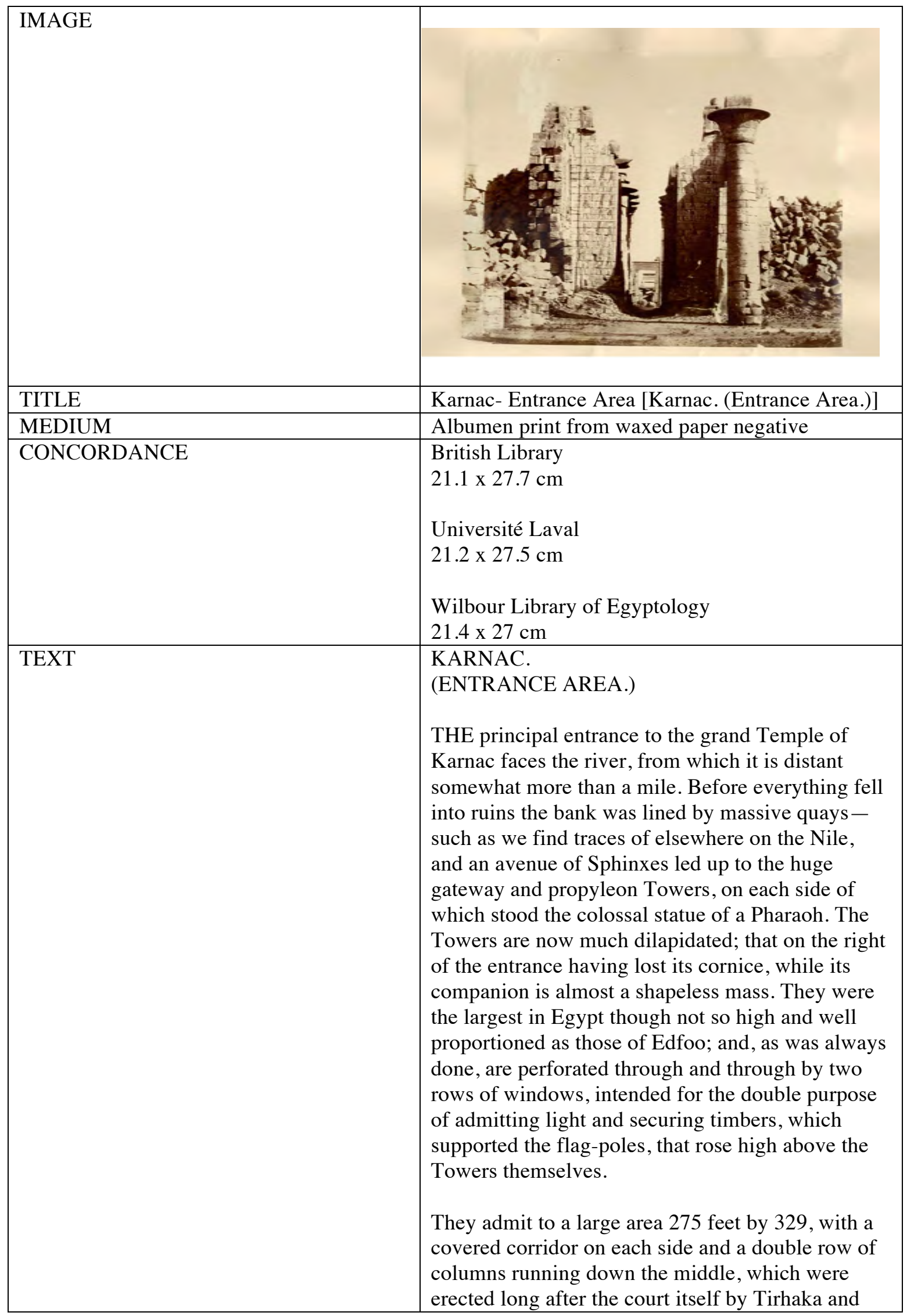




\begin{tabular}{|c|c|}
\hline & $\begin{array}{l}\text { Psammaticus, kings of the } 25 \text { th and 26th Dynasties. } \\
\text { The only one still perfect is seen in the photograph. } \\
\text { They had graceful, well proportioned shafts, which } \\
\text { were crowned by a bell-shaped capital and a plinth, } \\
\text { but seem never to have supported an architrave nor } \\
\text { to have fulfilled any constructive purpose. They are } \\
\text { therefore quite out of place, and are inconsistent } \\
\text { not only with the building, of which they do not } \\
\text { form a part, but with the character of the } \\
\text { architecture amidst which they stand. } \\
\text { This area was separated from the Grand Hall by } \\
\text { other Propylæ, which have now fallen into utter } \\
\text { ruin; and before the Pylon or Gateway is a } \\
\text { vestibule, whose walls are covered with the stiff an } \\
\text { vapid sculptures of the Ptolemaic period, the } \\
\text { original Pylon, built by Rameses II., having been } \\
\text { altered by Ptolemy Physcon, who added the } \\
\text { sculptures which now form such a painful contrast } \\
\text { to the superb and spirited designs which decorate } \\
\text { the Grand Hall within. Like all Greek structures, } \\
\text { however, it is well proportioned; and the materials } \\
\text { were of enormous size, the lentils of the gate being } \\
40 \text { feet } 10 \text { inches in length. } \\
\text { The view being taken immediately opposite the } \\
\text { gateway displays the two central rows of columns } \\
\text { in the Grand Hall and the Pylon beyond, which } \\
\text { admits to the Court built around the granite Shrine. } \\
\text { J.D., JR. }\end{array}$ \\
\hline NOTES & Image courtesy of Université Laval. \\
\hline
\end{tabular}

\begin{tabular}{|l|l|}
\hline IMAGE & \\
& \\
\hline TITLE & Karnac- Grand Hall- No.1 [Karnac. (Grand Hall, \\
& No. 1.)] \\
\hline MEDIUM & Albumen print from waxed paper negative \\
\hline
\end{tabular}




\begin{tabular}{|c|c|}
\hline CONCORDANCE & $\begin{array}{l}\text { British Library } \\
20.9 \times 27.5 \mathrm{~cm} \\
\text { Wilbour Library of Egyptology } \\
21.8 \times 27 \mathrm{~cm}\end{array}$ \\
\hline TEXT & 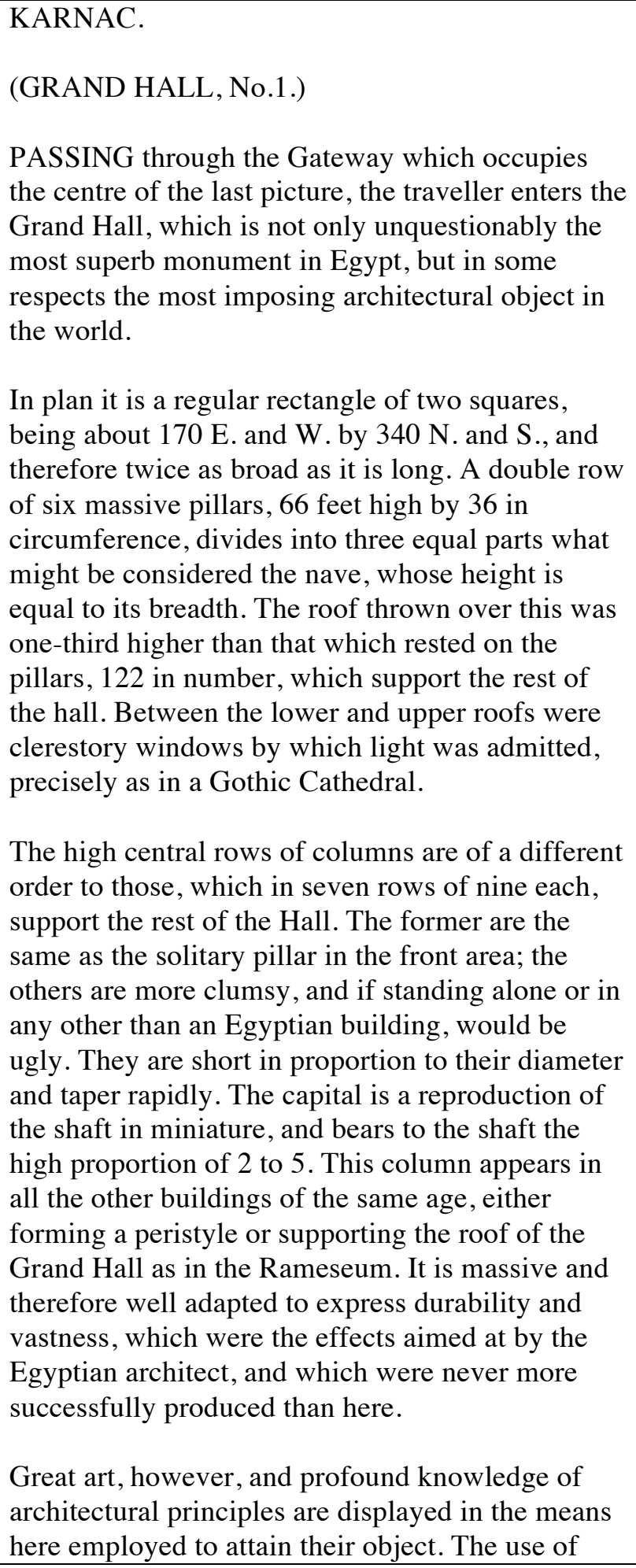 \\
\hline
\end{tabular}




\begin{tabular}{|l|l|}
\hline & $\begin{array}{l}\text { materials of immense size would to a certain extent } \\
\text { have done it, even had the materials been } \\
\text { unscientifically employed; or a design of enormous } \\
\text { dimensions would alone have been sufficient. But } \\
\text { the success would have been partial. In the } \\
\text { Pyramids, for instance, the same object was held in } \\
\text { view, by the architect; these simple means were } \\
\text { employed and the structures were necessarily huge } \\
\text { and imposing; yet owing to their design they are } \\
\text { apparently less enormous than they really are, } \\
\text { whereas the aim of an architect should be so to } \\
\text { dispose his masses that the apparent size may be } \\
\text { greater than the real; which was undoubtedly } \\
\text { attempted here. }\end{array}$ \\
\hline NOTES & $\begin{array}{l}\text { J.D., JR. } \\
\text { Library of Egyptology, Special Collections. }\end{array}$ \\
\hline
\end{tabular}

\begin{tabular}{|c|c|}
\hline IMAGE & \\
\hline TITLE & $\begin{array}{l}\text { Karnac- Grand Hall- No.2 [Karnac. (Grand Hall, } \\
\text { No. 2.)] }\end{array}$ \\
\hline MEDIUM & Albumen print from waxed paper negative \\
\hline CONCORDANCE & $\begin{array}{l}\text { British Library } \\
21.2 \times 27.8 \mathrm{~cm} \\
\text { Wilbour Library of Egyptology } \\
21.5 \times 27 \mathrm{~cm}\end{array}$ \\
\hline TEXT & $\begin{array}{l}\text { KARNAC. } \\
\text { (GRAND HALL, NO. 2.) } \\
\text { THE Hall is broader than it is long, a peculiarity } \\
\text { which would at first sight be accounted a defect, } \\
\text { and which in fact it would be, did it stand alone } \\
\text { and isolated. Being however but one part of a } \\
\text { grand architectural whole, and but one object, and }\end{array}$ \\
\hline
\end{tabular}




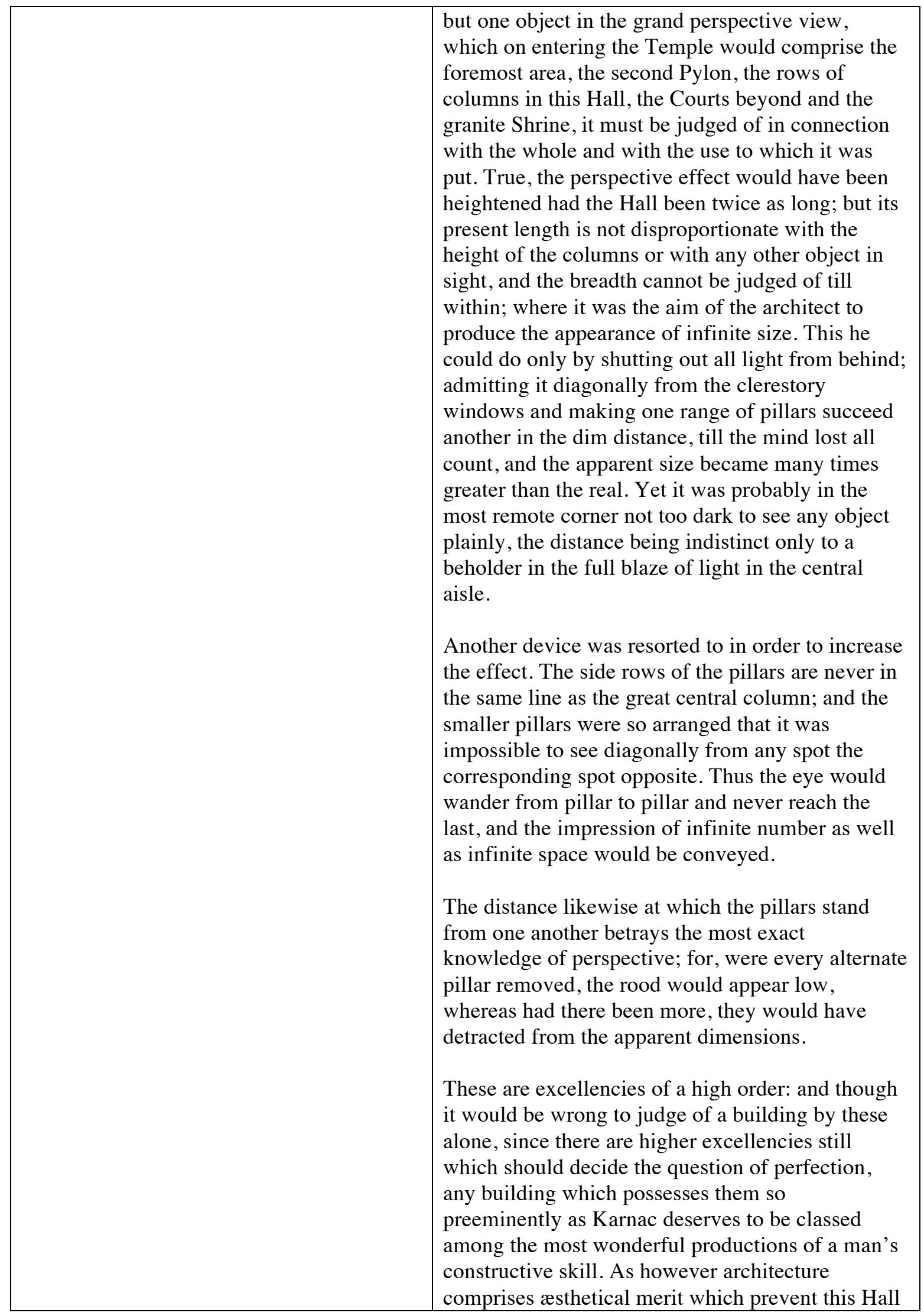




\begin{tabular}{|c|c|}
\hline & $\begin{array}{l}\text { being placed on a level with the Parthenon or the } \\
\text { finest models of Grecian architecture. In the proper } \\
\text { disposition of its masses to produce the desired } \\
\text { effect it may vie with the Athenian Temples on the } \\
\text { most magnificent gothic Cathedrals, but in every } \\
\text { æsthetical respect it is far inferior to the former and } \\
\text { probably also to the latter. The pillars taken singly } \\
\text { are not graceful; the sculptures, though well } \\
\text { arranged and well adapted to the spaces they fill, } \\
\text { are conventional in design, and the colouring, } \\
\text { though brillant, is not harmonious. } \\
\text { If however the highest aim of the architect is to } \\
\text { make his work expressive of intellectual and } \\
\text { religious thought and feeling, he who built this } \\
\text { Hall eminently succeeded. Not only does it in its } \\
\text { internal and external sculptures describe the } \\
\text { religion, and most graphically depict the historical } \\
\text { events of the period, but the architecture reflects } \\
\text { the national character in its immovable stolidity, } \\
\text { and the aspiration of the Egyptian mind. } \\
\text { The Egyptian believing that after a cycle of } 3000 \\
\text { years his soul would have made its progress } \\
\text { through the different bodies of the inferior animals } \\
\text { and would then return to the earth, unless in reward } \\
\text { for his righteousness it had been at once absorbed } \\
\text { into the deity, erected buildings which should be } \\
\text { still standing when he should revisit his former } \\
\text { haunts. It was this belief that made durability and } \\
\text { size the chief characteristic of Egyptian } \\
\text { architecture, and no structure ever combined these } \\
\text { qualities with high technic excellence so perfectly } \\
\text { as the Grand Hall of Karnac. } \\
\text { J.D., JR. }\end{array}$ \\
\hline NOTES & $\begin{array}{l}\text { Image from Brooklyn Museum Libraries. Wilbour } \\
\text { Library of Egyptology, Special Collections. }\end{array}$ \\
\hline
\end{tabular}




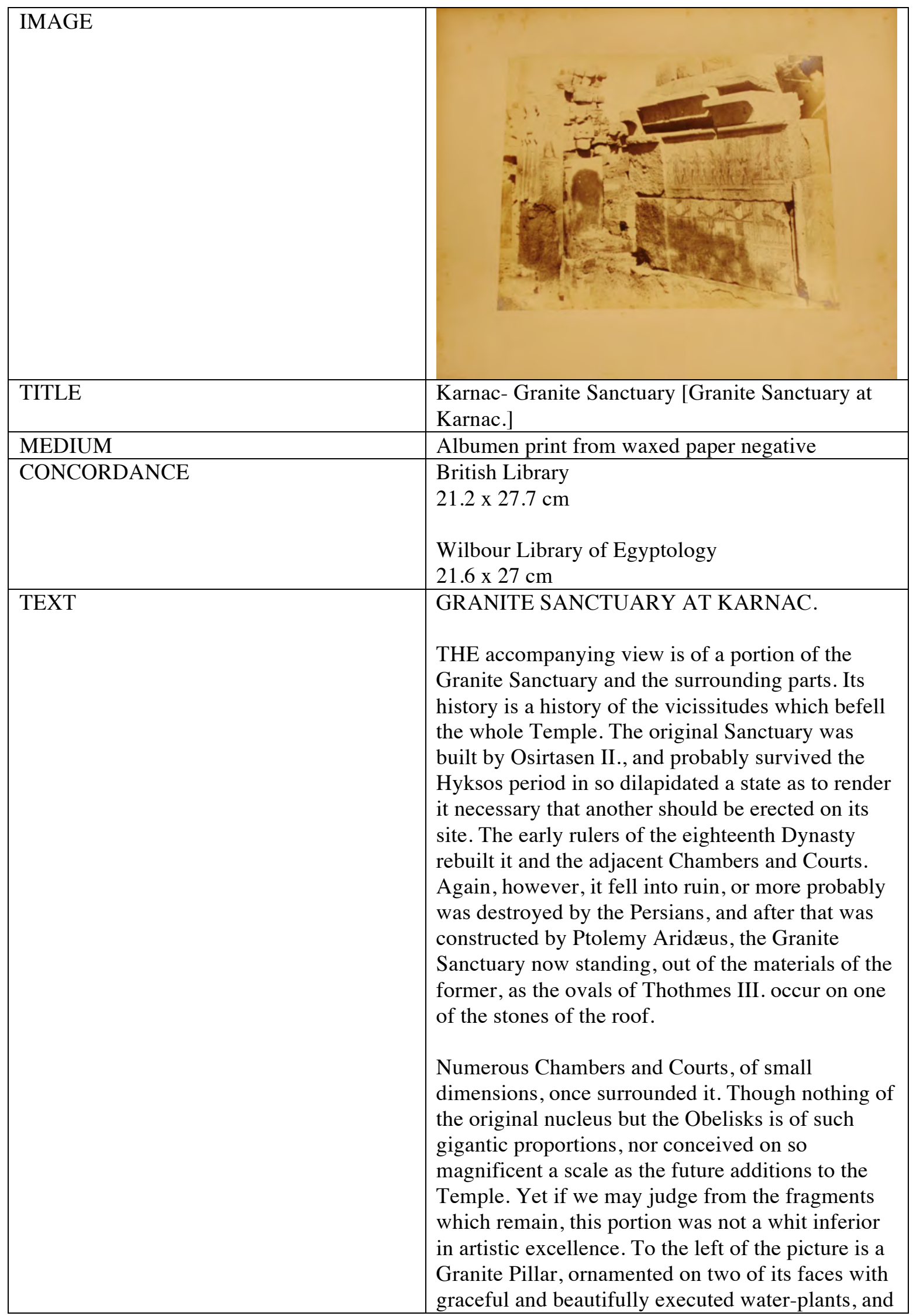




\begin{tabular}{|c|c|}
\hline & $\begin{array}{l}\text { other fragments lie about equally indicative of the } \\
\text { high state of the arts and the good taste which } \\
\text { characterized the architecture of the period. } \\
\text { The principal subject sculptured on the Sanctuary } \\
\text { wall represents a procession of several Shrines,- } \\
\text { the most important and imposing of the many } \\
\text { gorgeous rites in which the ceremonial worship of } \\
\text { the Egyptians consisted. The Shrines were of two } \\
\text { classes - the one of a canopy, the other a boat or } \\
\text { ark. The latter were the great Shrines, and were } \\
\text { carried in the same manner as the Ark of the } \\
\text { Israelites, by poles passing through rings, and } \\
\text { resting on the shoulders of } 12 \text { or } 16 \text { Priests. There } \\
\text { usually attends each Ark one or two Priests of a } \\
\text { superior grade, known by the plaited lock which } \\
\text { conceals the ear and bangs in a curl over the neck; } \\
\text { and if the nature of the ceremonial required the } \\
\text { Ark to be deposited anywhere during its } \\
\text { continuance, a stand, borne by as many as carry the } \\
\text { Ark, immediately follows. } \\
\text { Usually the Shrine of the principal deity, with } \\
\text { those of the contemplar gods and even others, was } \\
\text { deposited alongside their Statues in the Sanctuary; } \\
\text { and as a peculiar honour, a Shrine dedicated to the } \\
\text { ruling Pharaoh, was at times placed among them. } \\
\text { This we learn from the Rosetta Stone, which, after } \\
\text { enumerating the benefits conferred on the } \\
\text { Priesthood by Ptolemy Epiphanes, decrees:- "That } \\
\text { a Statue of the King shall be erected in every } \\
\text { Temple in the most conspicuous place; that near } \\
\text { him shall be a Statue of the presiding deity, } \\
\text { presenting him with the shield of victory; that the } \\
\text { Priests shall perform the customary ministrations } \\
\text { to the Statue, and that there shall be erected an } \\
\text { Image and a Golden Shrine of King Ptolemy in the } \\
\text { most honourable of the Temples, to be set up in the } \\
\text { Sanctuary among the other Shrines; and that in } \\
\text { great festivals when the procession of Shrines } \\
\text { takes place, that of the god Epiphanes shall } \\
\text { accompany them." } \\
\end{array}$ \\
\hline NOTES & $\begin{array}{l}\text { Image from Brooklyn Museum Libraries. Wilbour } \\
\text { Library of Egyptology, Special Collections. }\end{array}$ \\
\hline
\end{tabular}




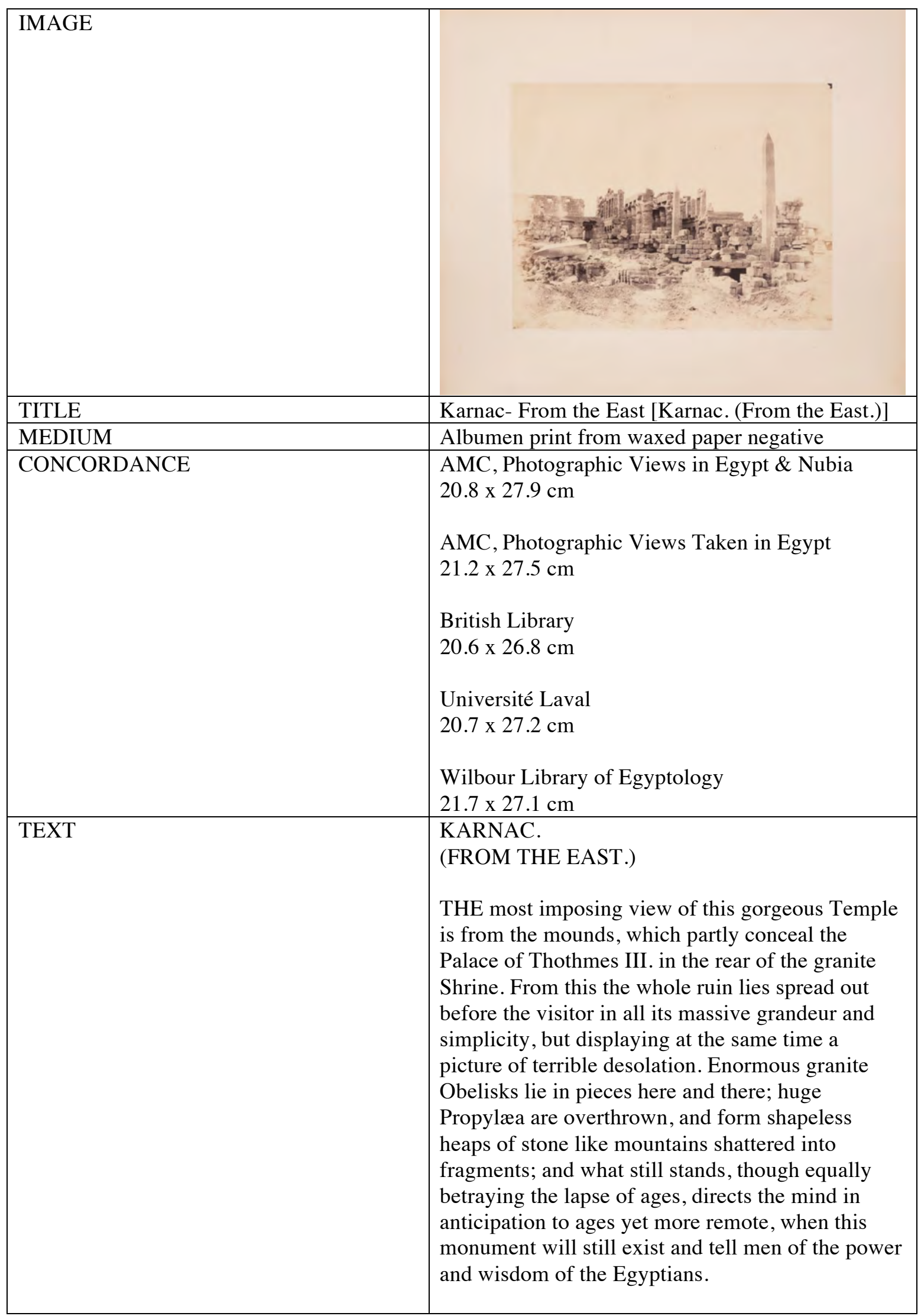




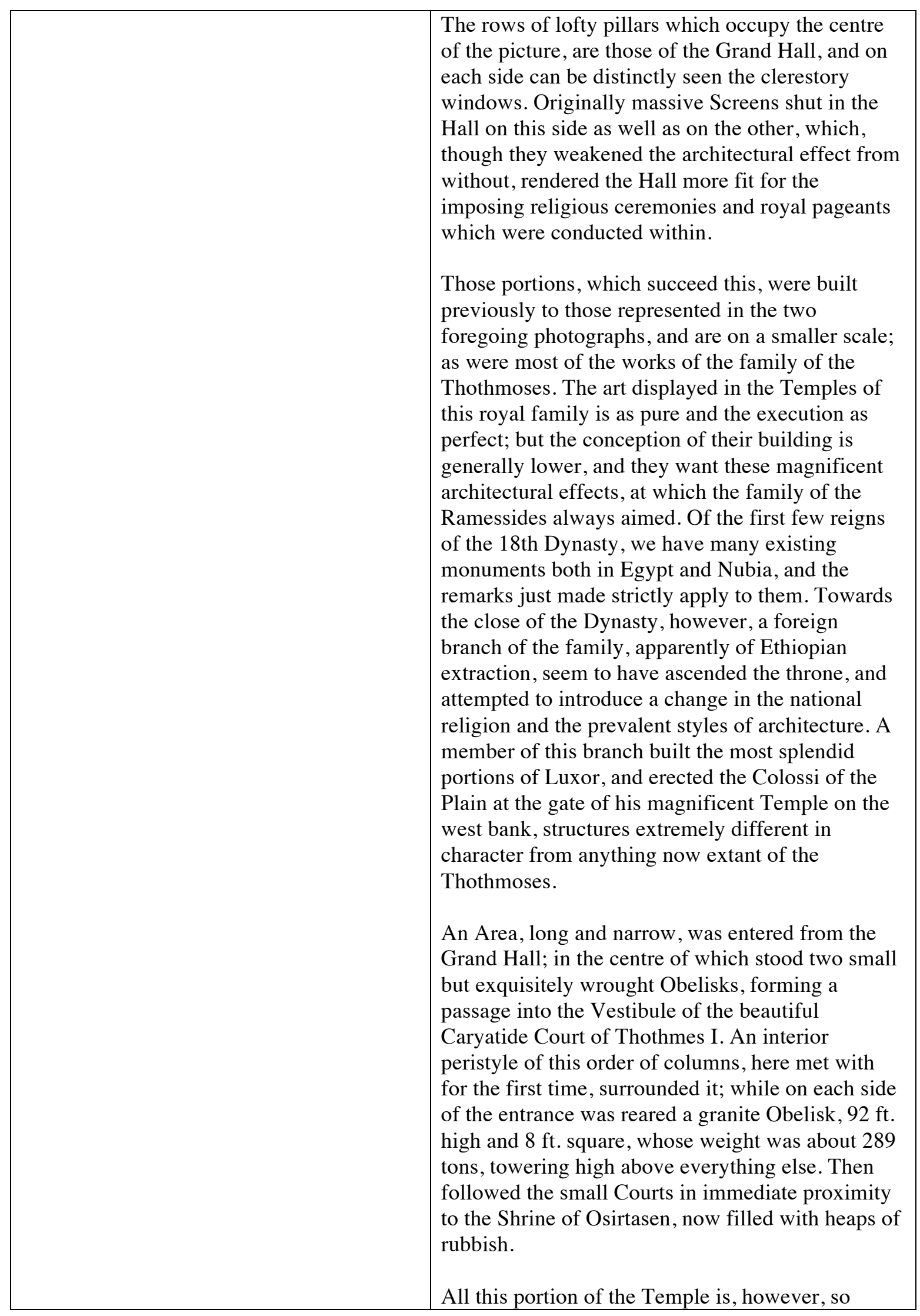




\begin{tabular}{|l|l|}
\hline & $\begin{array}{l}\text { dilapidated that it is difficult accurately to restore } \\
\text { even its ground-plan. The Shrine, sacred } \\
\text { religiously and historically, even in the New } \\
\text { Empire, stood in a large open space, which was } \\
\text { closed in on the east by the Temple-Palace of } \\
\text { Thothmes III., a building utterly devoid of all } \\
\text { artistic merit, though important as the receptacle of } \\
\text { one of the only two lists of kings, found on the } \\
\text { monuments. }\end{array}$ \\
\hline NOTES & $\begin{array}{l}\text { J.D., JR. } \\
\text { Image from AMC, Photographic Views Taken in } \\
\text { Egypt. As mentioned, Université Laval album has } \\
\text { the text from "Karnac- General View" paired with }\end{array}$ \\
\hline
\end{tabular}

\begin{tabular}{|l|l|}
\hline IMAGE & \\
& \\
& \\
\hline TITLE & \\
\hline MEDIUM & Karnac- Great Southern Temple [Karnac (Great \\
Southern Temple.)
\end{tabular}




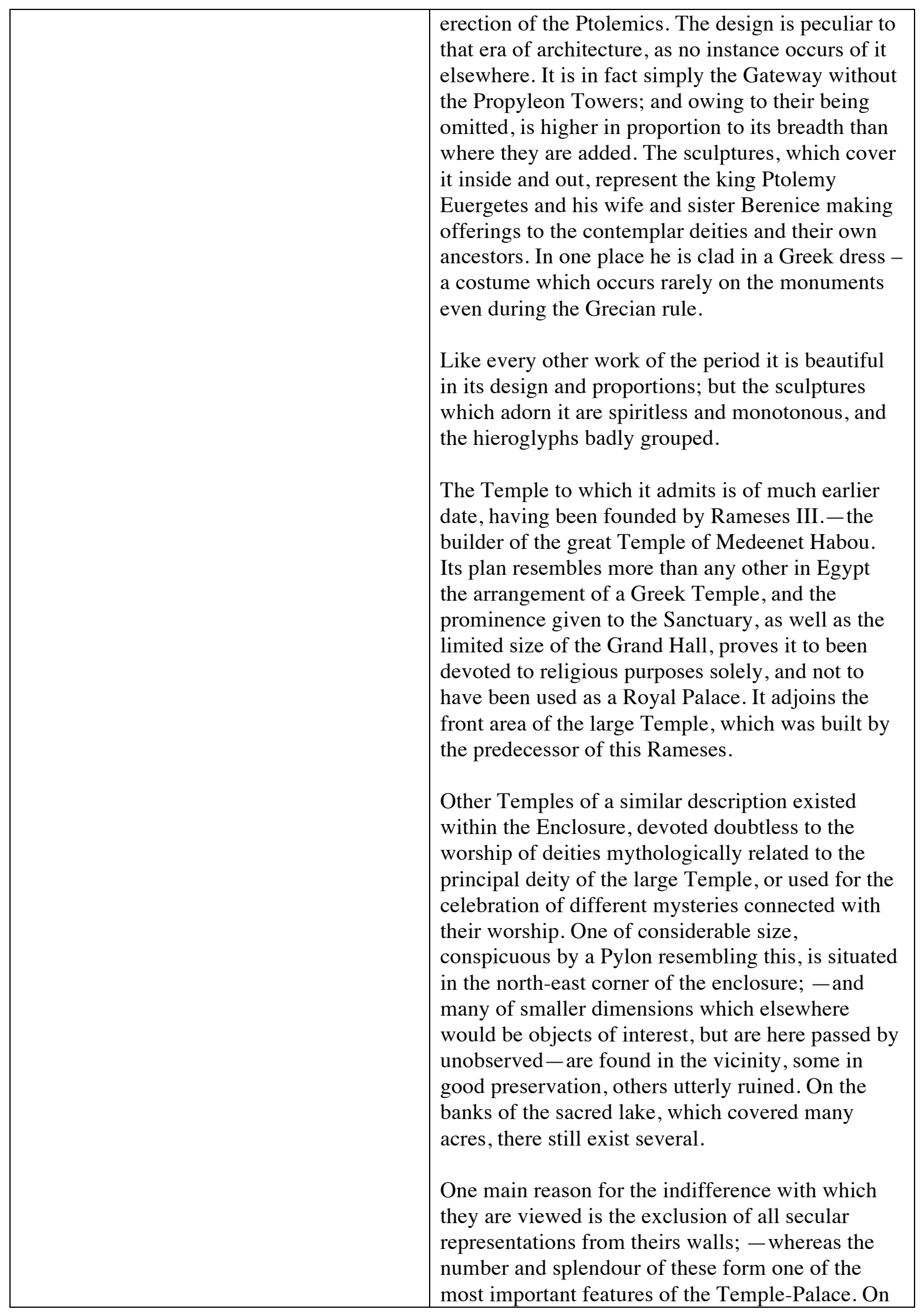




\begin{tabular}{|l|l|}
\hline & $\begin{array}{l}\text { the portion built by the house of Thothmes there } \\
\text { occur rows of prisoners, each bearing on a shield } \\
\text { the name of a conquered people. The custom of } \\
\text { giving a pictorial history of the campaign having } \\
\text { apparently not yet been introduced. On the outer } \\
\text { wall of the Grand Hall however are found some of } \\
\text { the most brilliant battle scenes which exist on any } \\
\text { monument of the 19th Dynasty. The conquests of } \\
\text { Sethos and his great son Rameses over certain } \\
\text { Eastern nations are there depicted with an artistic } \\
\text { power and a fidelity to life perfectly wonderful. } \\
\text { But none of the historical notices which this } \\
\text { glorious national monument has transmitted to us } \\
\text { are more important than the conquest recorded by } \\
\text { Shishak as having been made over the Jewish king } \\
\text { Rehoboam. }\end{array}$ \\
& $\begin{array}{l}\text { J.D., JR. } \\
\text { NOTES }\end{array}$ \\
$\begin{array}{l}\text { Image from AMC, Photographic Views in Egypt \& } \\
\text { Nubia. The image in the AMC, Photographic } \\
\text { Views in Egypt \& Nubia and Wilbour Library of } \\
\text { Egyptology albums have the same orientation, } \\
\text { while the image in the Universite Laval album is } \\
\text { laterally reversed. }\end{array}$ \\
\hline
\end{tabular}

\begin{tabular}{|l|l|}
\hline IMAGE & \\
& \\
& \\
& \\
\hline TITLE & \\
\hline MEDIUM & Esné [Esné.] \\
\hline CONCORDANCE & Albumen print from waxed paper negative \\
& AMC, Photographic Views in Egypt \& Nubia \\
& $21 \times 27.2 \mathrm{~cm}$ \\
& British Library \\
& $20.5 \mathrm{x} 26.9 \mathrm{~cm}$ \\
& Université Laval \\
& $20.8 \times 27 \mathrm{~cm}$ \\
\hline
\end{tabular}




\begin{tabular}{|c|c|}
\hline & $\begin{array}{l}\text { Wilbour Library of Egyptology } \\
22 \times 27 \mathrm{~cm}\end{array}$ \\
\hline TEXT & $\begin{array}{l}\text { ESNÉ. } \\
\text { A LARGE town on the west bank of the Nile, } \\
\text { contains about } 20,000 \text { inhabitants, and is the } \\
\text { residence of a Caliph. It possesses a tolerably well } \\
\text { supplied Bazaar. } \\
\text { It is however principally interesting to a traveller } \\
\text { from its Temple, and from the remains of the } \\
\text { massive and extensive stone quays on the river } \\
\text { side. } \\
\text { The town, as is seen by the Photograph, appears to } \\
\text { be built on a high mound, which rises on a slope } \\
\text { from the water's edge. Along the bank for a } \\
\text { considerable distance, are the remains of the } \\
\text { ancient quay, still in tolerable preservation and } \\
\text { which yet fulfills the purpose of its original } \\
\text { construction, by protecting the town from the } \\
\text { encroachments of the Nile. It also appears to have } \\
\text { been the river front of the avenue of sphinxes } \\
\text { which led to the Temple. } \\
\text { A small part of the ornamental cornice over the } \\
\text { Portico was visible in one of the yards of the } \\
\text { houses. A few years ago, Mehemet Ali caused } \\
\text { several of the houses to be removed, and an } \\
\text { extensive excavation to be made. This exposed the } \\
\text { river front of the Temple, and enabled the whole of } \\
\text { the great Hall to be thoroughly cleaned out, all the } \\
\text { remainder of this magnificent building still lies } \\
\text { buried in sand, and covered by Arab houses. The } \\
\text { entrance to it is through a yard near the principal } \\
\text { Bazaar. The front of the Temple is in such } \\
\text { excellent preservation that the colors of even the } \\
\text { portico are quite vivid. "We descended into the } \\
\text { great Hall by a long flight of steps, and on our way } \\
\text { passed some mummy cases, with their mummies } \\
\text { still in them, their hieroglyphics and inscriptions } \\
\text { on the cases had been effaced, and they, with their } \\
\text { contents were fast going to decay. The great Hall } \\
\text { with its twenty-four pillars is splendid, but looks } \\
\text { more ancient than Dendera. } \\
\text { "The whole of the walls, ceilings and pillars were } \\
\text { covered with sculptures, apparently of different } \\
\text { periods, some of them were in intaglio, and some } \\
\text { in high relief. In places, we observed where the } \\
\text { older sculptures had been chiseled out, and the } \\
\text { wall prepared for other. } \\
\text { "The Ram headed divinity seems to have been }\end{array}$ \\
\hline
\end{tabular}




\begin{tabular}{|l|l|}
\hline & $\begin{array}{l}\text { principally worshipped at Esné. Even the Bulls, } \\
\text { which are frequently sculptured on the walls, have } \\
\text { Ram's heads. } \\
\text { "We felt regret that the remainder of this very } \\
\text { interesting Temple had not been exposed. This } \\
\text { however could not be done without a great } \\
\text { destruction of property in the very heart of the } \\
\text { town." } \\
\text { *From Miss MACDONALD'S Journal. } \\
\text { J.D. }\end{array}$ \\
\hline NOTES & $\begin{array}{l}\text { Image from AMC, Photographic Views in Egypt \& } \\
\text { Nubia. }\end{array}$ \\
\hline
\end{tabular}

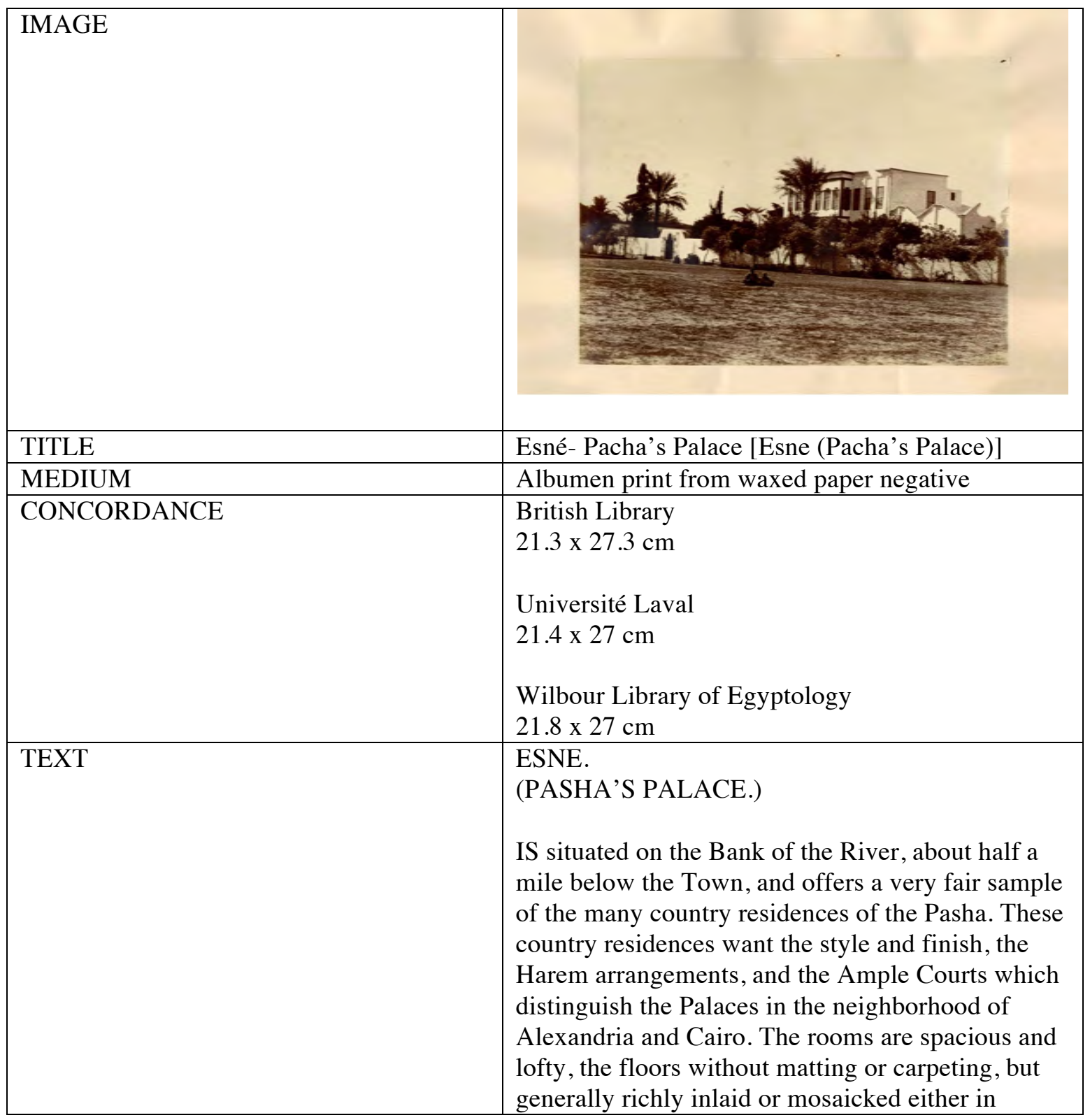




\begin{tabular}{|l|l|}
\hline & $\begin{array}{l}\text { marble or wood. The walls are covered with } \\
\text { expensive French paper and with a superabundance } \\
\text { of mirrors. There are no pictures, and, to a } \\
\text { European eye, a great scarcity of furniture-in the } \\
\text { larger rooms, in fact, the only articles of furniture } \\
\text { are the Divans. The houses themselves are } \\
\text { surrounded by gardens, and enclosed within high } \\
\text { walls. }\end{array}$ \\
J.D. \\
\hline NOTES & Image courtesy of Université Laval. \\
\hline
\end{tabular}

\begin{tabular}{|c|c|}
\hline IMAGE & \\
\hline TITLE & Pyramid of El Kufeh [Pyramid of El-Kufeh] \\
\hline MEDIUM & Albumen print from waxed paper negative \\
\hline CONCORDANCE & $\begin{array}{l}\text { AMC, Photographic Views in Egypt \& Nubia } \\
20.6 \text { x } 27.5 \mathrm{~cm} \\
\text { AMC, Photographic Views Taken in Egypt } \\
21 \times 28 \mathrm{~cm} \\
\text { British Library } \\
21.3 \times 27.3 \mathrm{~cm} \\
\text { Université Laval } \\
21.1 \times 26.7 \mathrm{~cm} \\
\text { Wilbour Library of Egyptology } \\
21 \times 27 \mathrm{~cm}\end{array}$ \\
\hline TEXT & $\begin{array}{l}\text { THE PYRAMID OF EL-KUFEH. } \\
\text { THE Pyramid El-Kufeh is the most southerly in } \\
\text { Egypt, being almost fifty miles above Thebes, and } \\
\text { is conjectured by Bunsen to be the most ancient. } \\
\text { Tradition makes the third successor of Menes, (the }\end{array}$ \\
\hline
\end{tabular}




\begin{tabular}{|l|l|}
\hline & $\begin{array}{l}\text { first historical King of Egypt, a builder of } \\
\text { Pyramids at Kocome, one of which has been } \\
\text { supposed identical with this heap of stones. As } \\
\text { however we have no data for determining the } \\
\text { precise position of Kocome, the conjecture rests on } \\
\text { the distant resemblance in name and on our being } \\
\text { unable to assign the Pyramid to any one else. } \\
\text { It is built on the edge of the limestone platform, } \\
\text { which here forms a well defined line between the } \\
\text { sandy desert and the narrow strip of cultivation; } \\
\text { and being therefore not above a quarter of a mile } \\
\text { from the river is distinctly seen from the deck of } \\
\text { the boat. It is only 38 feet high and 35 feet broad at } \\
\text { the base. It consists of 25 tiers of roughly hewn } \\
\text { stones, arranged in three steps, without any } \\
\text { cement. No entrance has yet been obtained. Its } \\
\text { construction determines a great antiquity, but its } \\
\text { situation militates against the idea of its being the } \\
\text { burial-place of a Memphitic King; most probably it } \\
\text { is the sepulcher of one of the subordinate Princes } \\
\text { who rules in different parts of Egypt } \\
\text { contemporaneously with the great Memphitic and } \\
\text { Theban dynasties, for we have no reason to think } \\
\text { that it or any other Pyramid was erected by a } \\
\text { private person. }\end{array}$ \\
\hline NOTES \\
J.D., JR. \\
$\begin{array}{l}\text { Image from AMC, Photographic Views Taken in } \\
\text { Egypt. }\end{array}$ \\
\hline
\end{tabular}

\begin{tabular}{|l|l|}
\hline IMAGE & \\
& \\
& \\
& \\
& \\
\hline TITLE & El Kab [El-Kab] \\
\hline MEDIUM & Albumen print from waxed paper negative \\
\hline CONCORDANCE & AMC, Photographic Views in Egypt \& Nubia \\
& $20.5 \mathrm{x} 27.1 \mathrm{~cm}$ \\
\hline
\end{tabular}




\begin{tabular}{|c|c|}
\hline & $\begin{array}{l}\text { AMC, Photographic Views Taken in Egypt } \\
21.5 \times 28 \mathrm{~cm} \\
\text { British Library } \\
21.2 \times 27.6 \mathrm{~cm} \\
\text { Wilbour Library of Egyptology } \\
21.8 \times 27 \mathrm{~cm}\end{array}$ \\
\hline TEXT & $\begin{array}{l}\text { EL-KAB } \\
\text { OCCUPIES the site of the ancient Eilythias, } \\
\text { which, judging from the extent of the city walls } \\
\text { and the number and beauties of the tomb in its } \\
\text { Necropolis, must have been a city of considerable } \\
\text { importance. } \\
\text { The wall-a portion of which is seen in the } \\
\text { Photograph opposite- must have enclosed about } \\
\text { thirty acres. It is forty feet high and wide enough to } \\
\text { permit of two chariots being driven abreast upon it. } \\
\text { As usual it is built of crude brick, made of Nile } \\
\text { mud mixed with a little sand, and dried in the sun. } \\
\text { Such crude-brick walls were probably thrown } \\
\text { round certain portions of all the cities, so as to } \\
\text { form a protection to the Temple Palaces, and all } \\
\text { but the suburbs, which must have extended far } \\
\text { beyond them. Accordingly we find broad inclined } \\
\text { planes leading up to the summit of the main wall, } \\
\text { while smaller enclosures within this surround the } \\
\text { Temples. In this instances a small enclosure on the } \\
\text { south side contains a few remains of a once } \\
\text { beautiful Temple of the } 18 \text { th and } 19 \text { th Dynasties, } \\
\text { and the sacred Lake, which was cased with } \\
\text { limestone; while another enclosure on the east, } \\
\text { with gates of solid masonry, marks the citadel } \\
\text { proper. These exists but one other city wall in } \\
\text { Egypt as perfectly preserved, that of Sais ; and the } \\
\text { disposition of the Temple, Citadel, \&c., within it, } \\
\text { much resembles that made here. } \\
\text { But there are numerous remains of crude brick } \\
\text { Temple Enclosure both in Thebes and elsewhere. } \\
\text { These Enclosures seem to have been as intrinsic a } \\
\text { part of the Temple as the Sanctuary itself; and at } \\
\text { certain periods as great care was taken to make } \\
\text { them historical records as the stone walls of the } \\
\text { Temple, for each brick was carefully stamped with } \\
\text { the monarch's name in whose reign they were }\end{array}$ \\
\hline
\end{tabular}




\begin{tabular}{|l|l|}
\hline & $\begin{array}{l}\text { made. It is a curious fact that we have more brick } \\
\text { remains of the period during which Israel was in } \\
\text { Egypt than of any other. }\end{array}$ \\
\hline NOTES & $\begin{array}{l}\text { J.D., JR. } \\
\text { Egage from AMC, Photographic Views Taken in }\end{array}$ \\
\hline
\end{tabular}

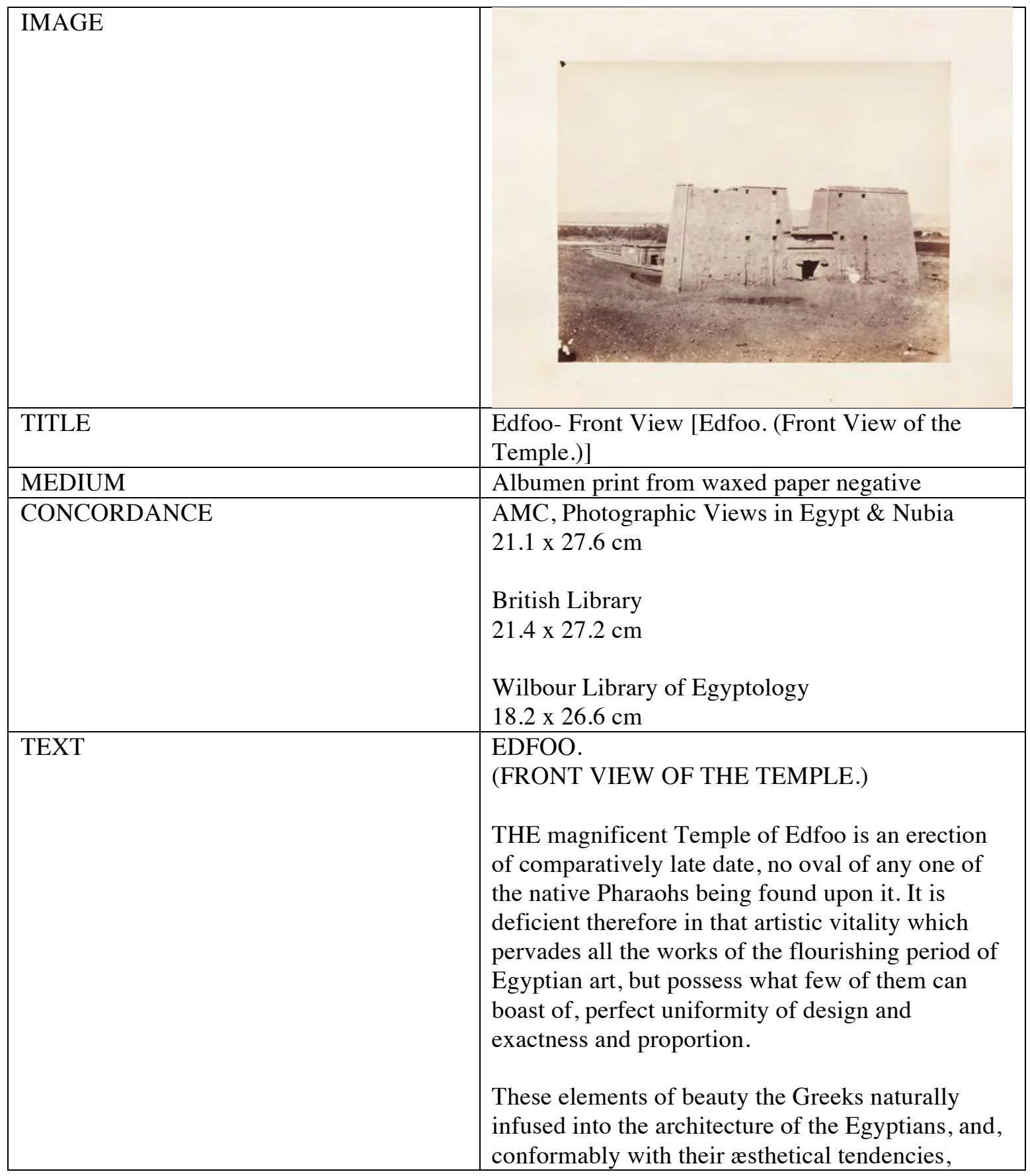




\begin{tabular}{|c|c|}
\hline & $\begin{array}{l}\text { assigned them a prominence foreign to the genius } \\
\text { of the style with which they sought to blend them. } \\
\text { They produced, as a result, buildings often of huge } \\
\text { dimension, well proportioned and of great } \\
\text { technical merit; possessing therefore every } \\
\text { excellency which a thorough knowledge of } \\
\text { architectural principles and the use of good models } \\
\text { would ensure, but lacking in the higher } \\
\text { excellencies of art, originality and spirit, and } \\
\text { betraying a woeful degeneracy in the delineation of } \\
\text { the human figure, and the grouping of the } \\
\text { hieroglyphical symbols, on which, as the principal } \\
\text { decorative element in Egyptian architecture much } \\
\text { of its expressiveness necessarily depends. The } \\
\text { Temple of Edfoo is a good example of the beauties } \\
\text { and defects of Ptolemaic art. } \\
\text { It was founded by Ptolemy Philometor, and } \\
\text { completed by his immediate successors, but some } \\
\text { of the sculptures were added by Claudius Cæsar. } \\
\text { The original plan was never, however, departed } \\
\text { from, those whom piety prompted to record their } \\
\text { names, being content to do so on some vacant wall } \\
\text { of the Towers or other unoccupied spot. It, as well } \\
\text { as all the Temples of the same date, are moreover } \\
\text { distinguished from the larger of the Pharaonic, by } \\
\text { being devoted exclusively to religious purposes. It } \\
\text { is therefore much easier to determine the use to } \\
\text { which the several parts were devoted; and this (in } \\
\text { the present case) is still further facilitated by the } \\
\text { excellent preservation in which the building still is, } \\
\text { having been effectually protected by the } \\
\text { accumulation of rubbish, which entirely } \\
\text { surrounded and filled it till within a very few years. } \\
\text { Formerly it was impossible to gain admittance at } \\
\text { all to some of the chambers, and an Arab village } \\
\text { had, perhaps for centuries, occupied the roof. Now, } \\
\text { one wanders from hall to hall, up stairs and } \\
\text { through passages, with far more freedom and } \\
\text { facility than when the Priests of the god Hor-Hat } \\
\text { jealously guarded the Shrine and restricted the } \\
\text { worshipper to the Outer Court and Grand Hall. } \\
\end{array}$ \\
\hline NOTES & $\begin{array}{l}\text { Image from AMC, Photographic Views in Egypt \& } \\
\text { Nubia. }\end{array}$ \\
\hline
\end{tabular}




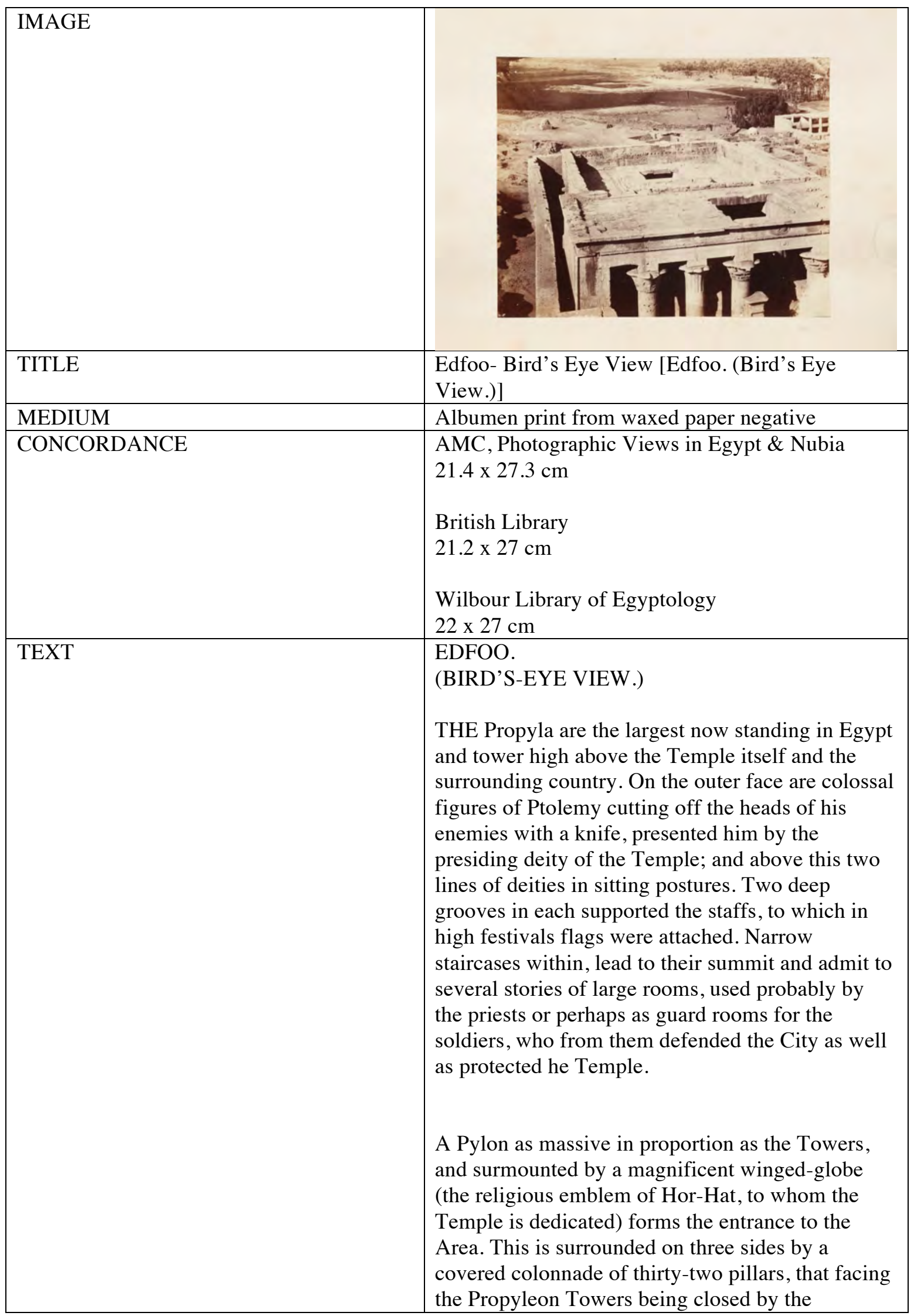




\begin{tabular}{|c|c|}
\hline & $\begin{array}{l}\text { intercolumnar screen of the Portico. The Portico } \\
\text { itself is supported by sixteen large columns. To it } \\
\text { succeeds the Pronaos, which is, as is always the } \\
\text { case, somewhat lower, and smaller, being } \\
\text { supported by only twelve columns. Then follow a } \\
\text { transverse Corridor, leading into the Sactuary or } \\
\text { Adytum which stands almost isolated from the rest } \\
\text { of the building. It is built with sloping walls and a } \\
\text { cornice, and is intended to be a Temple within a } \\
\text { Temple. Around it runs a passage, off which are a } \\
\text { number of side Adyta. There are also several } \\
\text { lateral chambers connected with the Pronaos, a } \\
\text { winding staircase leads from it to the roof. A small } \\
\text { building detached from the rest, but within the } \\
\text { Temple, is situated to the left of the Transept. It } \\
\text { contains but one room supported by two columns } \\
\text { in front and approached by a flight of steps. It was } \\
\text { probably devoted to some special mysteries } \\
\text { connected with the worship of the god, and may } \\
\text { have been similar in this respect to the small } \\
\text { building always found in the vicinity of the large } \\
\text { Temple; in which, it has been conjectured, were } \\
\text { celebrated the rites connected with the birth of the } \\
\text { third person of the Temple triad. } \\
\text { A stone wall thirty feet high encloses the whole } \\
\text { Temple. Even it is adorned with colossal figures, } \\
\text { as well executed as the most minute sculptures on } \\
\text { the interior walls. } \\
\text { The photograph, which gives a bird's-eye view of } \\
\text { the whole, being taken from the summit of the } \\
\text { eastern Tower, shows distinctly the mode of } \\
\text { admitting light to the interior, a method far less } \\
\text { calculated to heighten the effect than the clerestory } \\
\text { windows of the Hypostyle Hall of Karnac. } \\
\text { J.D., JR. }\end{array}$ \\
\hline NOTES & $\begin{array}{l}\text { Image from AMC, Photographic Views in Egypt \& } \\
\text { Nubia. }\end{array}$ \\
\hline
\end{tabular}




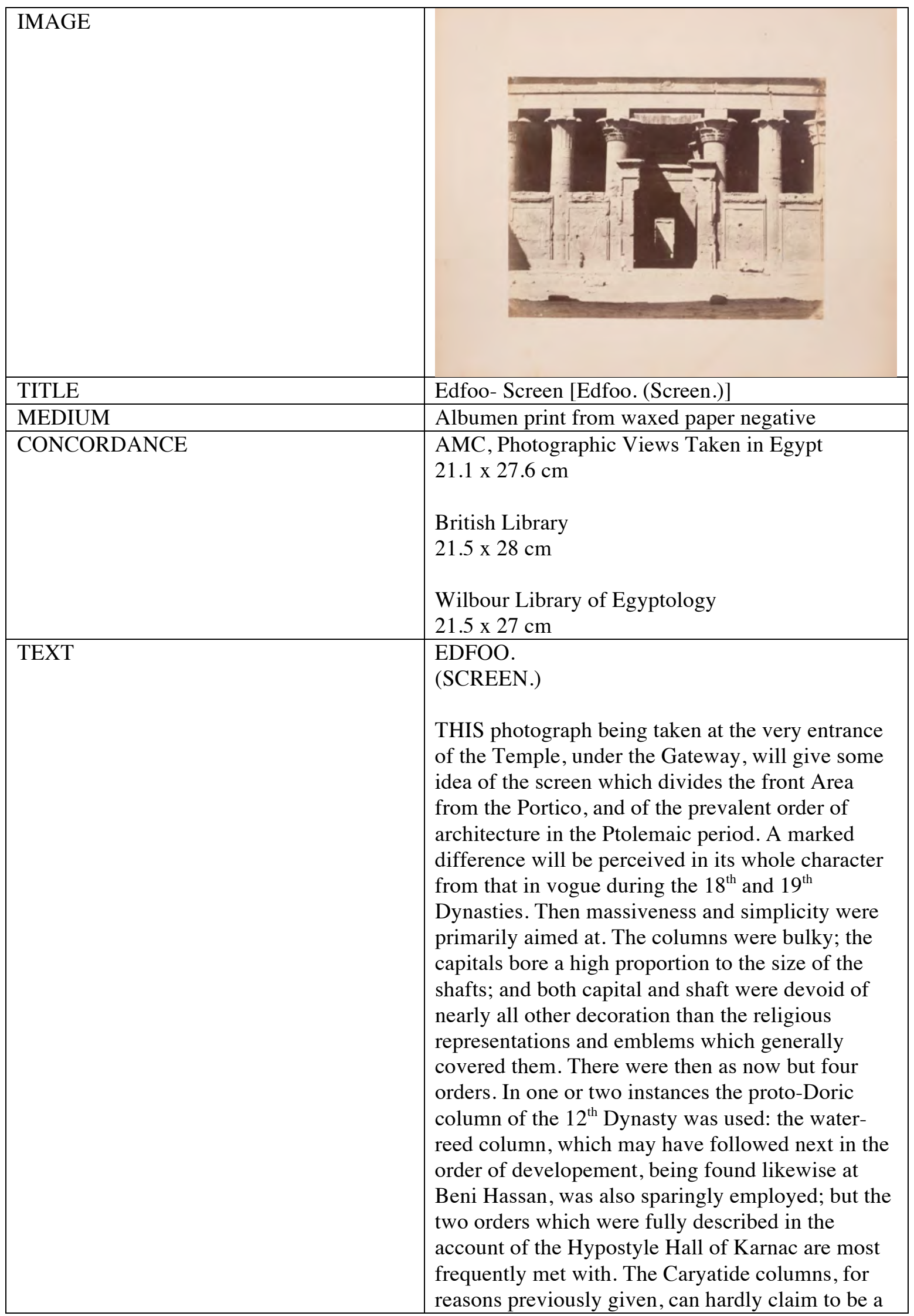




\begin{tabular}{|c|c|}
\hline & $\begin{array}{l}\text { distinct order. In the Ptolemaic buildings however, } \\
\text { under the influence of Greek taste and Greek } \\
\text { architecture, the simplicity and uniformity, which } \\
\text { had previously distinguished the Egyptian, yielded } \\
\text { to a more florid style, which displayed itself (as } \\
\text { seen in our picture) in the variety which was } \\
\text { sought to be given to the capitals and the panels } \\
\text { with which the screen were divided, and by other } \\
\text { unmistakable indications. } \\
\text { These departures from the original spirit of the } \\
\text { architecture may have imparted to it a beauty } \\
\text { which it could not possess before - but yet they do } \\
\text { not embody the ponderous thoughts and beliefs } \\
\text { which the older style so forcibly conveys; while at } \\
\text { the same time they are not sufficiently Hellenistic } \\
\text { to narrate their history independently of the } \\
\text { inscriptions which are cut upon them. } \\
\text { How little reliance may be put upon opinions } \\
\text { drawn from such internal evidence as the } \\
\text { monuments themselves afford to those ignorant of } \\
\text { hieroglyphical writing, was strikingly proved by } \\
\text { the egregious mistakes made by the Savans who } \\
\text { accompanied Napoleon. Not the least glaring of } \\
\text { these, was the error into which they fell in regard } \\
\text { to the relative age and artistic superiority of the } \\
\text { Pharaonic and Ptolemaic remains:- an error } \\
\text { occasioned however in great measure by the } \\
\text { discovery of a Zodiac on the ceiling of the Portico } \\
\text { at Dendera, which their astronomical calculations } \\
\text { led them to suppose must have been placed there in } \\
\text { almost antedeluvian age. } \\
\text { J.D., JR. }\end{array}$ \\
\hline NOTES & $\begin{array}{l}\text { Image from AMC, Photographic Views Taken in } \\
\text { Egypt. }\end{array}$ \\
\hline
\end{tabular}




\begin{tabular}{|c|c|}
\hline IMAGE & \\
\hline & $=\int_{4}^{P}$ \\
\hline TITLE & $\begin{array}{l}\text { Kom Ombos-Temple Enclosure [Kom Ombos. } \\
\text { (Temple Enclosure.)] }\end{array}$ \\
\hline MEDIUM & Albumen print from waxed paper negative \\
\hline CONCORDANCE & $\begin{array}{l}\text { AMC, Photographic Views Taken in Egypt } \\
20.4 \text { x } 28 \mathrm{~cm} \\
\text { British Library } \\
20.4 \times 26.4 \mathrm{~cm} \\
\text { Wilbour Library of Egyptology } \\
21.9 \times 26.6 \mathrm{~cm}\end{array}$ \\
\hline TEXT & $\begin{array}{l}\text { KOM OMBOS. } \\
\text { (TEMPLE ENCLOSURE.) } \\
\text { THE Temple of Kom Ombos is like that of Edfoo, } \\
\text { last described, of the time of the Ptolemies, and is } \\
\text { one of the finest specimens of their architecture. If } \\
\text { quite uncovered it would be a noble pile; - for } \\
\text { though not of great extent, the materials of which it } \\
\text { is constructed are of extraordinary size, and its } \\
\text { situation on the very brink of the river enhances } \\
\text { not a little its own beauties. } \\
\text { Extensive remains here strew the banks, and are } \\
\text { every year being washed away. They are, however, } \\
\text { so ruined that it is impossible with any degree of } \\
\text { certainty to restore the structures to which they } \\
\text { belonged, - or even to determine the use of such } \\
\text { portion of the quays and other works facing the } \\
\text { river as are still standing. } \\
\text { Originally a Temple, dedicated to Sevak the } \\
\text { Crocodile-headed deity, was built on this spot by } \\
\text { Thothmes III, and the Queen-Regent, whose name } \\
\text { is often conjoined with his and that of his }\end{array}$ \\
\hline
\end{tabular}




\begin{tabular}{|c|c|}
\hline & $\begin{array}{l}\text { predecessor in many of the Theban monuments. Of } \\
\text { this Temple there remains only the small granite } \\
\text { gateway, which is seen built into the crude brick } \\
\text { wall of the Enclosure; and a few blocks here and } \\
\text { there, some inscribed with their ovals, and others, } \\
\text { which, by their style bespeak their own antiquity. It } \\
\text { had probably already fallen into decay when the } \\
\text { Ptolemies used its materials in the construction of } \\
\text { another, dedicated to Arøris as well as Sevak who } \\
\text { was the protecting deity of Ombos. } \\
\text { Looking at the Temple and its Enclosure from the } \\
\text { sand bank on the opposite side of the Nile, which } \\
\text { is still a favourite resort of the Crocodiles, where } \\
\text { they perhaps shed tears over their departed } \\
\text { greatness, there is seen at the south-east corner, } \\
\text { towering some } 40 \text { ft. above the Temple Platform, } \\
\text { itself } 15 \text { ft. above the low Nile, part of a once } \\
\text { grateful gateway. Its true proportion will be best } \\
\text { appreciated by comparing its height with that of } \\
\text { one of our sailors at its base. } \\
\text { A little north of this is a circular structure probably } \\
\text { connected with a winding staircase, which led up } \\
\text { from the river to the Platform; and at the north-east } \\
\text { corner are the remains of what was once a small } \\
\text { but highly finished Temple, if we may judge from } \\
\text { the blocks of sculptured stones which lie piled one } \\
\text { upon another on the bank. From one of these } \\
\text { blocks we succeeded with considerable difficulty } \\
\text { in sawing off the head of Cleopatra, who is there } \\
\text { represented making an offering to Athor. } \\
\text { The back part of the Enclosure is so filled up that it } \\
\text { is uncertain whether other buildings exist there. } \\
\text { The Enclosure itself, though not large, is in } \\
\text { tolerable preservation, considering that in the } \\
\text { bricks of which it is built much more sand that } \\
\text { usual is mixed with the mud. } \\
\text { J. JR. }\end{array}$ \\
\hline NOTES & $\begin{array}{l}\text { Image from AMC, Photographic Views Taken in } \\
\text { Egypt. }\end{array}$ \\
\hline
\end{tabular}




\begin{tabular}{|c|c|}
\hline IMAGE & \\
\hline TITLE & Kom Ombos- Temple [Kom Ombos. (Temple.)] \\
\hline MEDIUM & Albumen print from waxed paper negative \\
\hline CONCORDANCE & $\begin{array}{l}\text { AMC, Photographic Views in Egypt \& Nubia } \\
20.1 \times 27.1 \mathrm{~cm} \\
\text { AMC, Photographic Views Taken in Egypt } \\
21.3 \times 27.6 \mathrm{~cm} \\
\text { British Library } \\
21 \times 27.5 \mathrm{~cm} \\
\text { Wilbour Library of Egyptology } \\
21.2 \times 27 \mathrm{~cm}\end{array}$ \\
\hline TEXT & $\begin{array}{l}\text { KOM OMBOS. } \\
\text { (THE TEMPLE.) } \\
\text { THE Portico of the Great Temple is not more than } \\
50 \text { feet distant from the edge of the bank. A } \\
\text { peculiarity in its plan immediately strikes one. } \\
\text { Above the architrave, between the principal } \\
\text { columns, are two winged-globes, corresponding } \\
\text { with two gateways leading into the Great Hall. } \\
\text { This again with every part of the Temple is double. } \\
\text { Each of the two deities therefore, to which the } \\
\text { Temple was dedicated, possessed a separate } \\
\text { Shrine, though both were under the same roof. } \\
\text { The Portico is supported by three rows of five } \\
\text { columns each, which display the same variety in } \\
\text { the design of their capitals as those at Edfou and } \\
\text { every other building of that period. The architraves } \\
\text { and roof are stones of cyclopean size; and on some } \\
\text { of the latter are several pieces of sculpture, left in } \\
\text { an unfinished state, where the mode of squaring } \\
\text { the surface preparatory to drawing the design is } \\
\text { well exemplified. A different scale is used from } \\
\text { that of the } 18^{\text {th }} \text { and } 19^{\text {th }} \text { Dynasties. }\end{array}$ \\
\hline
\end{tabular}




\begin{tabular}{|l|l|}
\hline & $\begin{array}{l}\text { The Pronaos resembles the Portico in its columnar } \\
\text { arrangement. Above the gateway of the Adytum is } \\
\text { a Greek inscription, running thus:-- "For the } \\
\text { welfare of King Ptolemy and Queen Cleopatra, his } \\
\text { sister, god Philometores and their children, the } \\
\text { infantry, cavalry and others stationed in the Ombos } \\
\text { home, have erected the Adytum to the great god } \\
\text { Aroeris Apollo, and to the contemplar gods for } \\
\text { their benevolence towards them." }\end{array}$ \\
\begin{tabular}{ll} 
J.D., JR. \\
\hline NOTES
\end{tabular} & $\begin{array}{l}\text { Image from AMC, Photographic Views Taken in } \\
\text { Egypt. AMC, Photographic Views in Egypt \& } \\
\text { Nubia and Wilbour Library of Egyptology have a } \\
\text { laterally reversed orientation in relation to AMC, } \\
\text { Photographic Views Taken in Egypt. }\end{array}$ \\
\hline
\end{tabular}




\section{NUBIA}

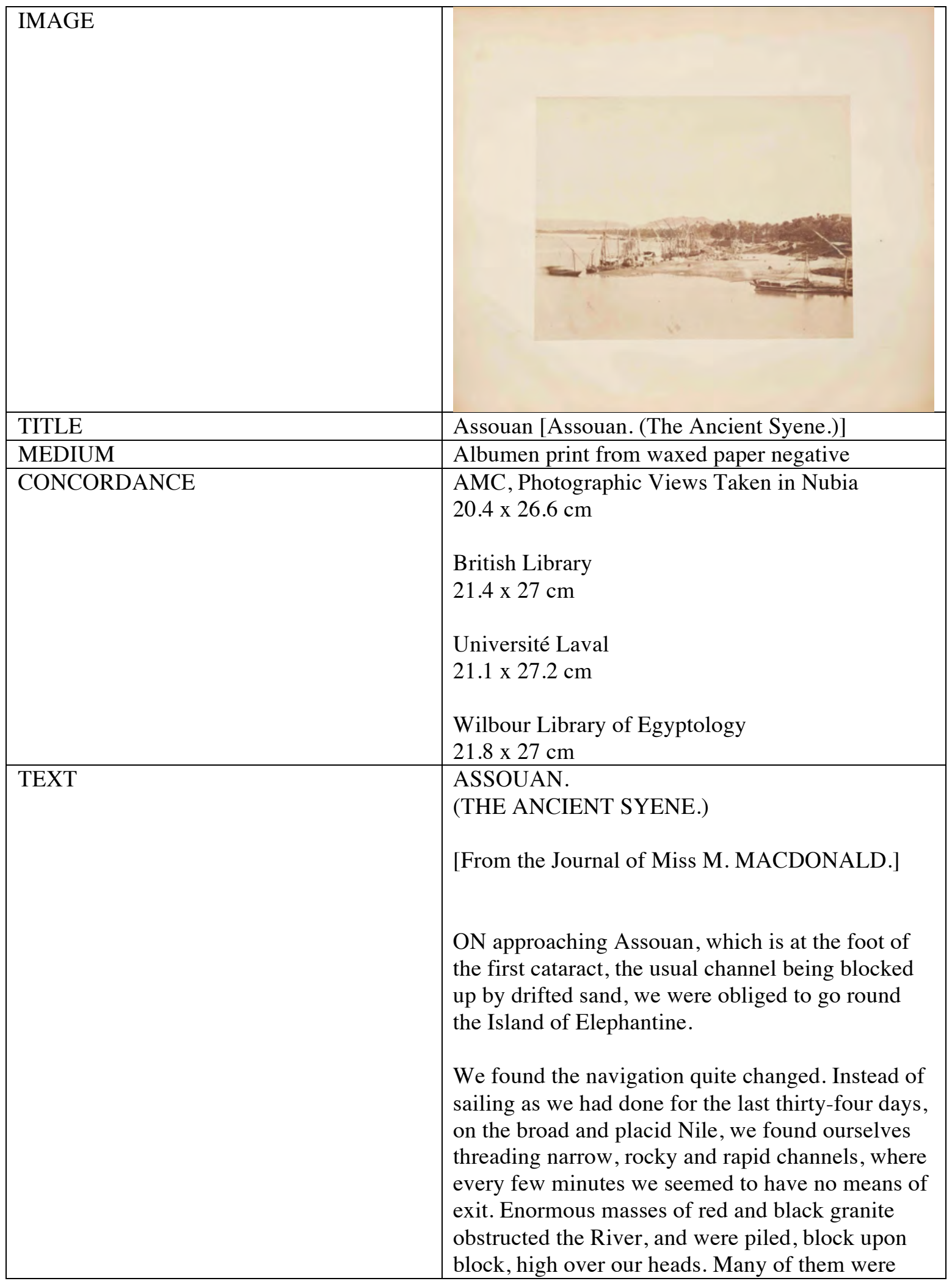




\begin{tabular}{|l|l|}
\hline covered with inscriptions. \\
& $\begin{array}{l}\text { Assouan itself is a miserable and dirty place, and } \\
\text { owes its importance solely to being the Frontier } \\
\text { Town of Egypt to the South, and the place where } \\
\text { the Caravans from Abysinia, Dongola and } \\
\text { Soudan, and the interior of Africa arrive and } \\
\text { depart. }\end{array}$ \\
$\begin{array}{l}\text { On reaching the landing, a Caravan was just } \\
\text { arriving. Strings of Camels were being led down to } \\
\text { the beach and relieved of their heavy loads, by a } \\
\text { wild, black, half naked, and savage looking set of } \\
\text { Arabs. The babble sounds of men and camels, was } \\
\text { perfectly fearful. We could not ascertain the } \\
\text { number of the camels but thought them not short of } \\
\text { 300. After they had gone, we strolled through the } \\
\text { crowd, and among the packages of merchandize, } \\
\text { which consisted principally of Senna, Gums, } \\
\text { Dates, Ebony and Elephants' Tusks. Some of these } \\
\text { tusks were very large; we measured one which was } \\
\text { nine feet, and weighed 160 pounds. About } 10 \text { in } \\
\text { the evening we again strolled through the } \\
\text { encampment, most of the people were stretched on } \\
\text { mats on the ground, some were sitting in small } \\
\text { knots, talking and smoking. The noise and } \\
\text { confusion had died away, or had subsided into a } \\
\text { mere murmur. }\end{array}$ \\
\hline NOTES \\
$\begin{array}{l}\text { Image from AMC, Photographic Views Taken in } \\
\text { Nubia. }\end{array}$ \\
\hline
\end{tabular}

\begin{tabular}{|l|l|}
\hline IMAGE & \\
& \\
& \\
& \\
\hline TITLE & Elephantine [Island of Elephantine.] \\
\hline MEDIUM & Albumen print from waxed paper negative \\
\hline CONCORDANCE & AMC, Photographic Views Taken in Egypt \\
\hline & \\
\hline
\end{tabular}




\begin{tabular}{|c|c|}
\hline & $\begin{array}{l}\text { AMC, Photographic Views Taken in Nubia } \\
20.3 \times 27 \mathrm{~cm} \\
\text { British Library } \\
20.9 \times 27.4 \mathrm{~cm} \\
\text { Wilbour Library of Egyptology } \\
21.8 \times 26.9 \mathrm{~cm}\end{array}$ \\
\hline TEXT & $\begin{array}{l}\text { ISLAND OF ELEPHANTINE } \\
\text { IS situated at the foot of the first cataract, and } \\
\text { immediately opposite Assouan from which it is } \\
\text { separated by a narrow channel of the river. It was } \\
\text { in old times the frontier of Egypt to the South, } \\
\text { contained a strong garrison, and was, from its } \\
\text { situation, a place of considerable importance, even } \\
\text { the seat of one or more of the dynasties. } \\
\text { The photograph is of the South end of the island, } \\
\text { and shews the lower part of the famous Nilometer, } \\
\text { a portion of the ancient stone quay, a large granite } \\
\text { gateway near the top of the hill, and sundry ruins } \\
\text { of Temples. All the remainder of this part of the } \\
\text { Island consists of mounds of rubbish, bricks, and } \\
\text { broken pottery, interspersed with sculptured stones } \\
\text { and pieces of statues. } \\
\text { "Tempus Edax rerum," if } i t \text { alone had been the } \\
\text { destroyer, many of the magnificent buildings, with } \\
\text { which this Island was covered, would still have } \\
\text { remained, but many of the houses in Assouan are } \\
\text { indebted to Elephantine for the materials of their } \\
\text { construction; in going through the streets and } \\
\text { bazaars you are at every step attracted by } \\
\text { sculptured stones, built into the walls, and used as } \\
\text { lintels and door steps. Some of these stones are } \\
\text { beautifully sculptured, and readily mark the Era of } \\
\text { their original execution. Only a few years since } \\
\text { one of the local Governors demolished a beautiful } \\
\text { but small Temple of elegant proportions and which } \\
\text { had served as a model to the Greeks; he at the } \\
\text { same time removed the upper chambers of the } \\
\text { Nilometer for the purpose of building himself a } \\
\text { Palace in the neighbourhood of the town. } \\
\text { Of the Nilometer, as may be seen in the } \\
\text { photograph, only the lower part remains; it, } \\
\text { however, is still in tolerable preservation, and } \\
\text { some of the inscriptions which marked the rise of }\end{array}$ \\
\hline
\end{tabular}




\begin{tabular}{|l|l|}
\hline & $\begin{array}{l}\text { the Nile, two thousand years ago, are still distinct. } \\
\text { There are now no inhabitants on the Island } \\
\text { excepting a few families of Nubians on the north } \\
\text { end, who gain a scanty subsistence by cultivating a } \\
\text { small strip of land, by fishing, and by grubbing } \\
\text { among the ruins for antiques. }\end{array}$ \\
\hline NOTES & $\begin{array}{l}\text { J.D. } \\
\text { Nubia. Wilbour Library of Egyptology and AMC, } \\
\text { Photographic Views Taken in Nubia have the same } \\
\text { orientation of the image, while the image in the } \\
\text { AMC, Photographic Views Taken in Egypt album } \\
\text { is laterally reversed. }\end{array}$ \\
\hline
\end{tabular}

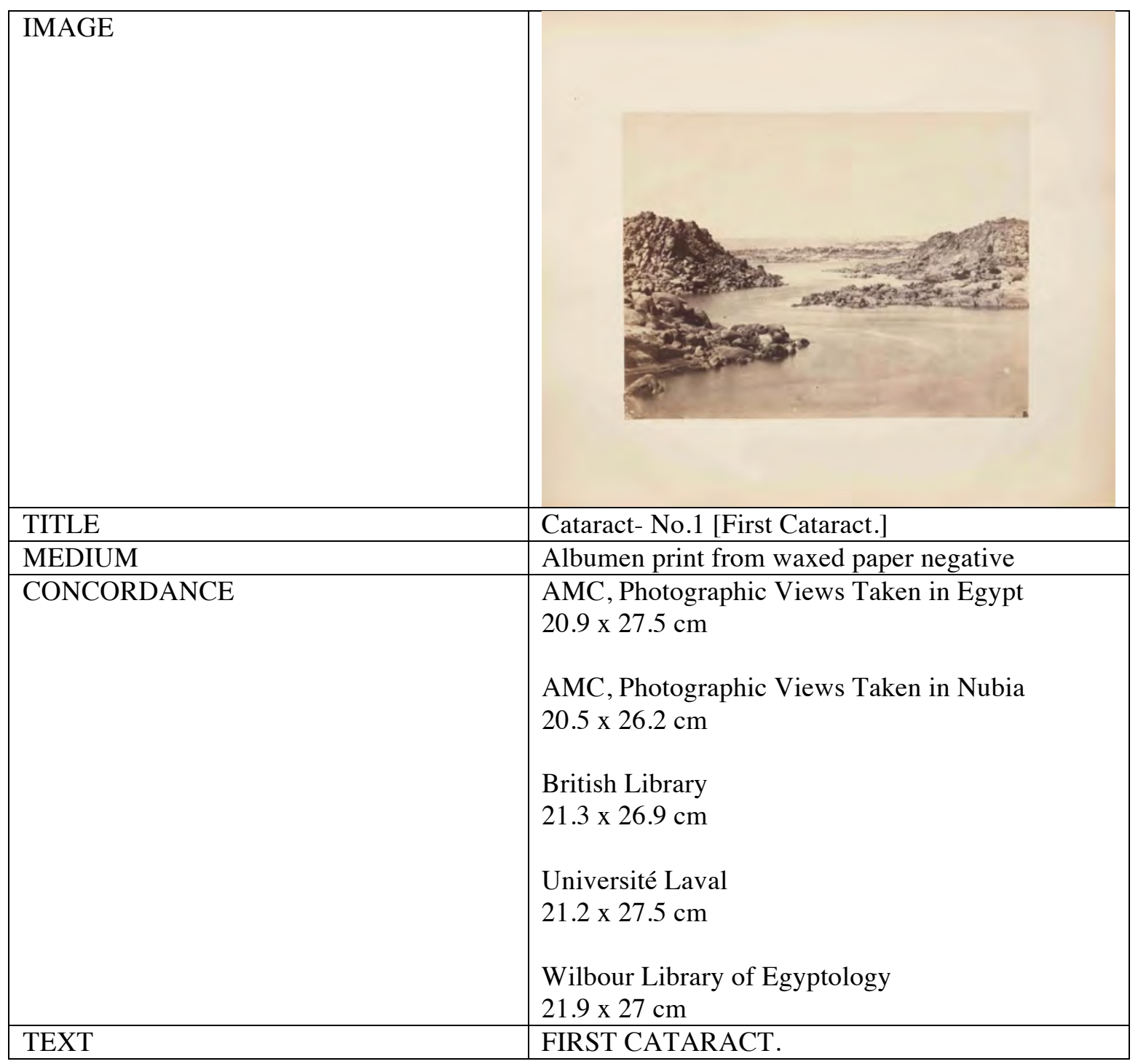


MAY rather be considered as a succession of rapids. There is reason to suppose that a complete rocky barrier existed here at some former period, certainly upwards of 3000 years ago.

Deposits of Nile mud and fresh water shells are found immediately above the Cataract, and at other places in Nubia, particularly at Korusko; at this place the present caravan road to Soudan, leaves the Nile, and passes through a broad gorge between the hills; this gorge has been overflowed by the river, as is proved by the enormous deposits of alluvium in situations upwards of thirty feet above the level of the highest present rise of the river.

The remains of the ancient granite barrier which existed at the first cataract, now consist, as shewn in the photograph, of a number of small islands and huge pointed rocks, through which the Nile forces its way, by a great many very tortuous channels, but in none is there any proper fall or cataract. To natives, accustomed to the smooth and silent flow of the river below Assonan, these rapids seem something wonderful and dangerous, but, to a Canadian, accustomed to the rapids and waterfalls of Canada, they seem insignificant.

In ascending, the Dahabieh is dragged up through the rocky channels, by means of long ropes, manned by a crowd of Arabs, who line the rocks on each side, and whose activity either in or out of the water is surprizing. In descending, the boat makes a chute through one channel, very narrow, and very deep, where the fall is about eight feet in one hundred and fifty yards. This appears to be the greatest fall, though not the largest rapid.

In the greater rapid, through which the boat is dragged in coming up, Nubians, for a few coppers, jump in, and swim, or rather allow themselves to be carried down by the current. But, even among these people who are almost amphibious, only a very few attempt it. A Mr. Cave, an Irish gentleman attempted it last week but, although a practiced swimmer, and moreover provided with a life-preserver, he sank, and his body was only recovered two days ago. 


\begin{tabular}{|l|l|}
\hline & $\begin{array}{l}\text { The natives say, that, in these rapids the undertow } \\
\text { is so great, that only those accustomed to them, } \\
\text { and who possess great power of endurance under } \\
\text { water, can pass them by swimming. I noticed that } \\
\text { even they were driven under water by the force of } \\
\text { the current and that several seconds elapsed before } \\
\text { they reappeared. }\end{array}$ \\
J.D. \\
\hline NOTES & $\begin{array}{l}\text { Image from AMC, Photographic Views Taken in } \\
\text { Nubia. }\end{array}$ \\
\hline
\end{tabular}

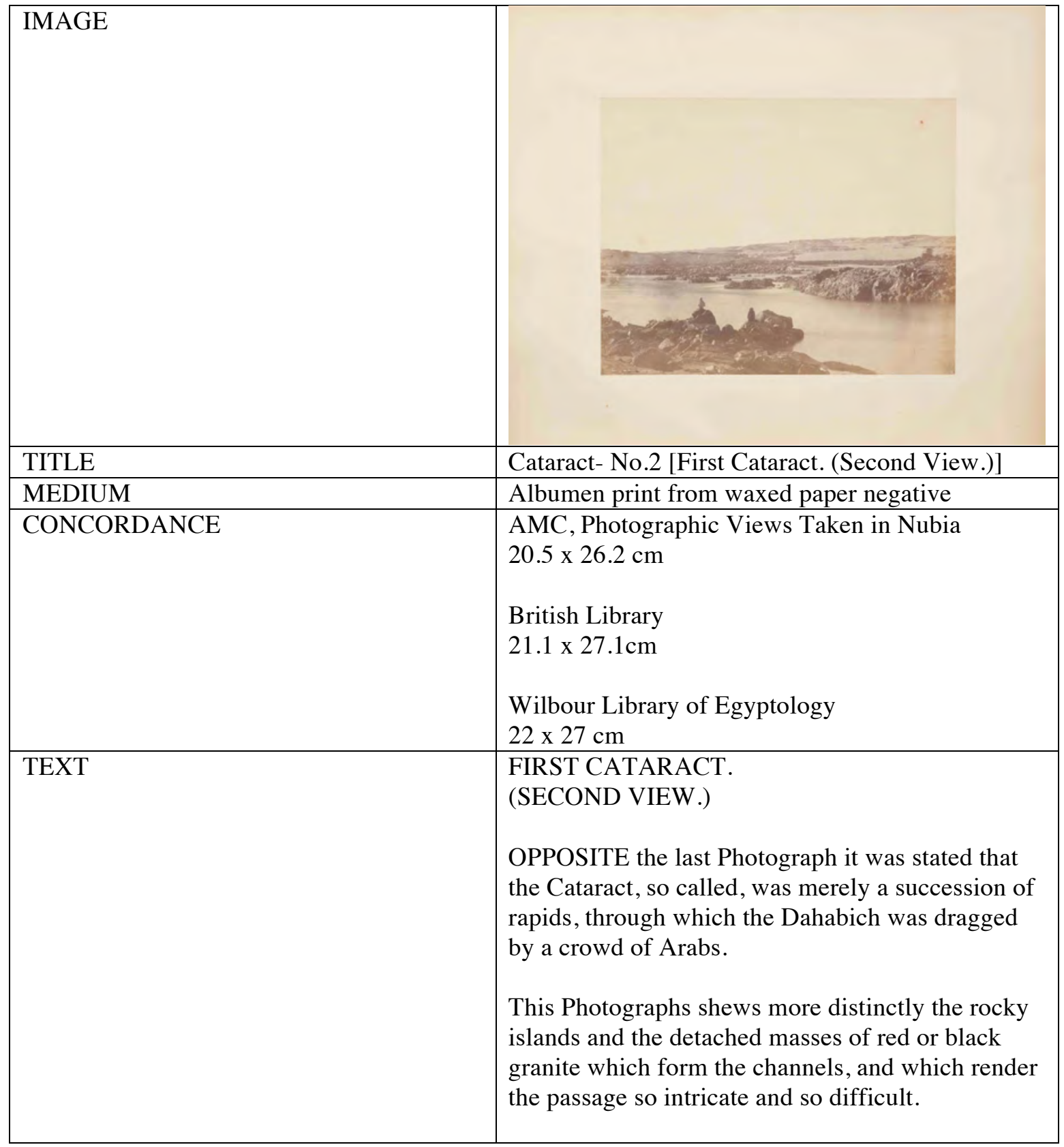




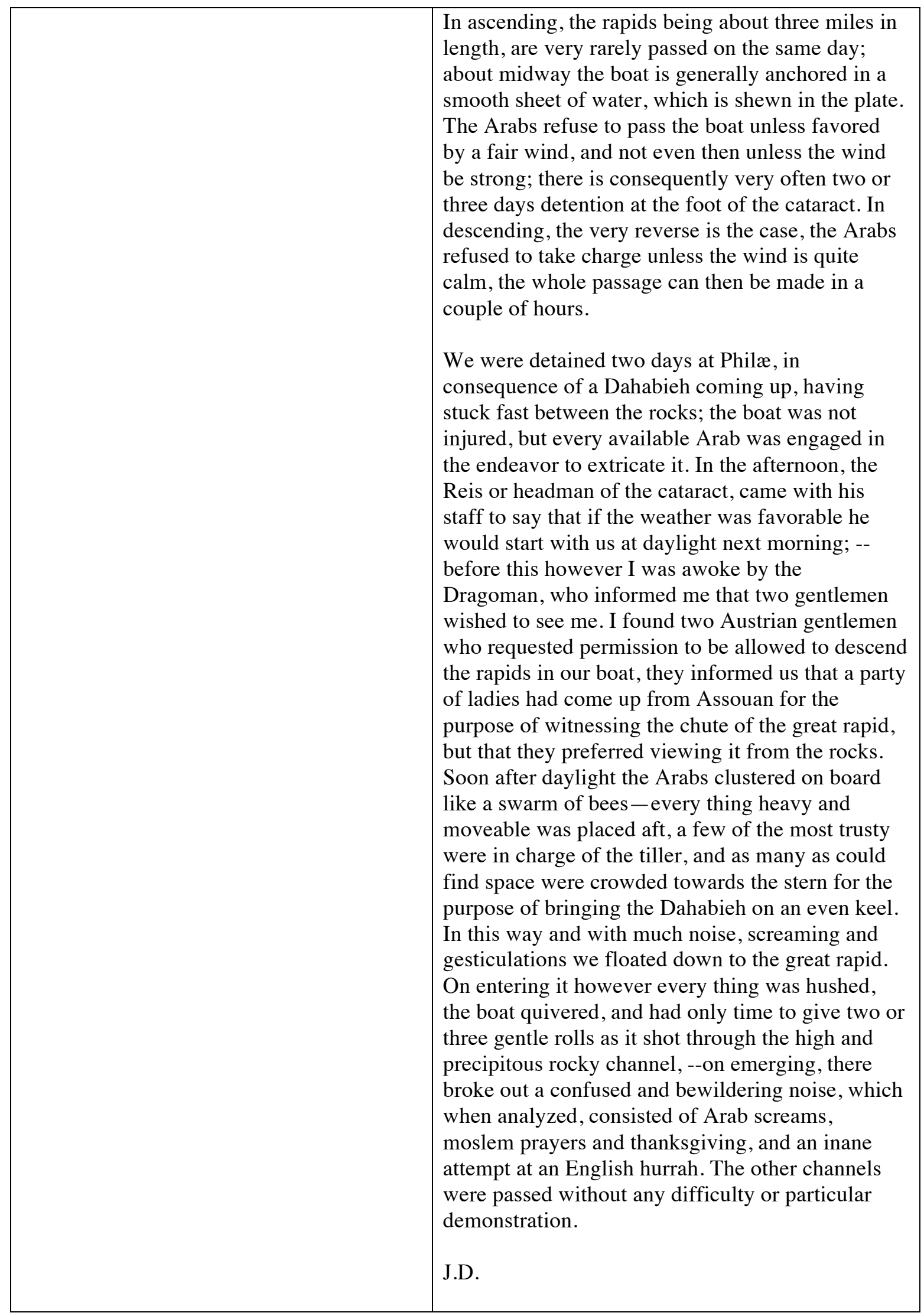




\begin{tabular}{|l|l|}
\hline NOTES & $\begin{array}{l}\text { Image from AMC, Photographic Views Taken in } \\
\text { Nubia. }\end{array}$ \\
\hline
\end{tabular}

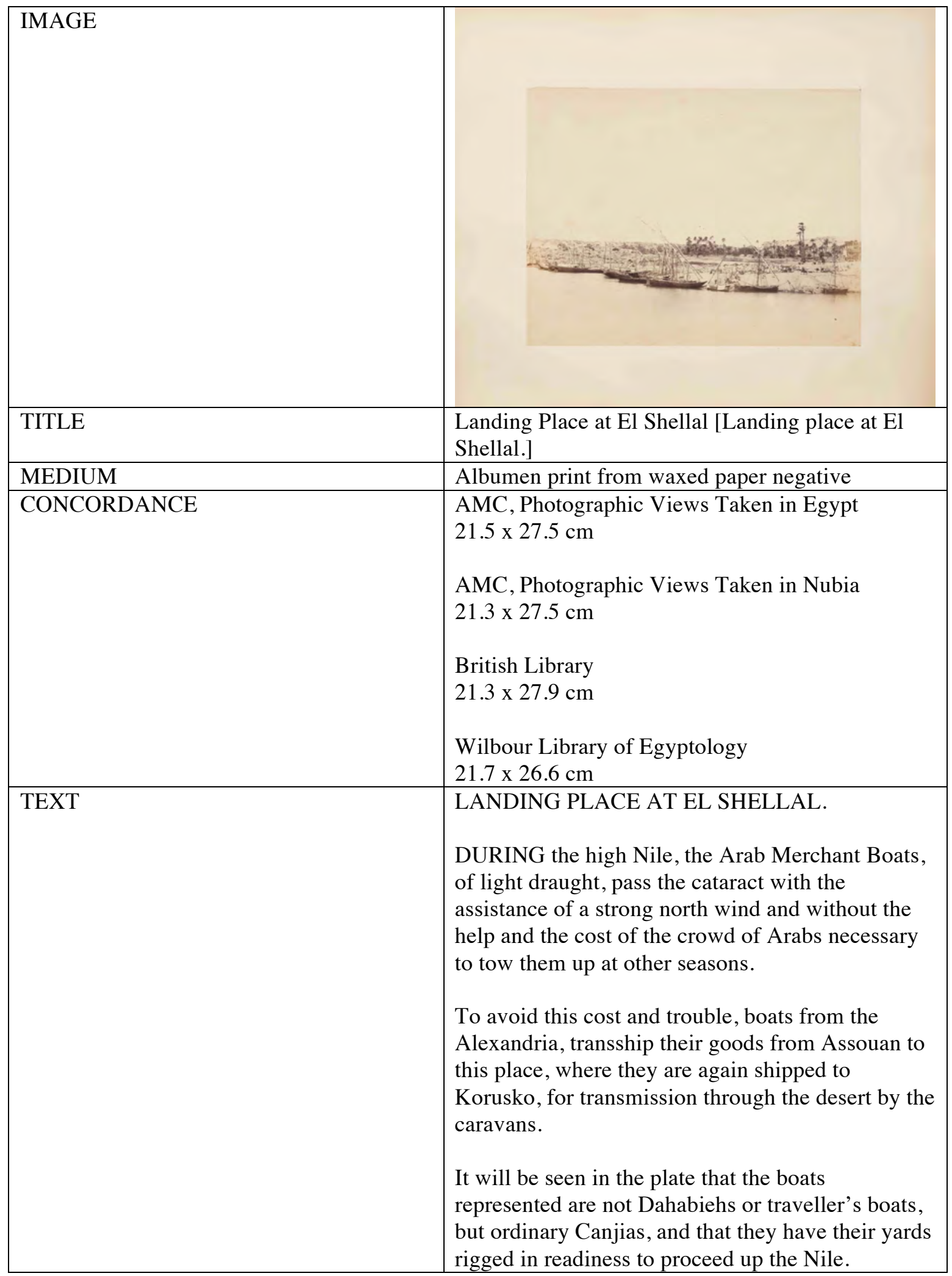




\begin{tabular}{|l|l|}
\hline & J.D. \\
\hline NOTES & $\begin{array}{l}\text { Image from AMC, Photographic Views Taken in } \\
\text { Nubia. }\end{array}$ \\
\hline
\end{tabular}

\begin{tabular}{|c|c|}
\hline IMAGE & \\
\hline TITLE & Canjia [Canjia.] \\
\hline MEDIUM & Albumen print from waxed paper negative \\
\hline CONCORDANCE & $\begin{array}{l}\text { AMC, Photographic Views Taken in Nubia } \\
20.6 \times 27.3 \mathrm{~cm} \\
\text { British Library } \\
20.3 \times 27.9 \mathrm{~cm} \\
\text { Wilbour Library of Egyptology } \\
21.4 \text { x } 27 \mathrm{~cm}\end{array}$ \\
\hline TEXT & $\begin{array}{l}\text { CANJIA. } \\
\text { THE boats used on the Nile vary as much in size } \\
\text { and in construction as they do in the uses to which } \\
\text { they are put. The boats used by European or by the } \\
\text { better class of Arab travellers, are the Dahabieh, } \\
\text { the Rahleh, and the Canjia, all of these are decked, } \\
\text { and possess cabins; but besides these there are } \\
\text { many others, some of very large size for the } \\
\text { conveyance of grain, cotton, or merchandize, some } \\
\text { for carrying stone, some as ferry, and some as } \\
\text { fishing boats, none of these are decked, or have } \\
\text { cabins, and excepting the boats for carrying stone } \\
\text { which have a square sail, all the others are rigged } \\
\text { alike with the short mast forward, and the long } \\
\text { fishing rod looking yard for the lateen sail, which } \\
\text { is made like a bird's wing. } \\
\text { Opposite the photograph of the Nile boat, a }\end{array}$ \\
\hline
\end{tabular}




\begin{tabular}{|l|l|}
\hline & $\begin{array}{l}\text { description was given of the mode in which it was } \\
\text { fitted up; this applies more or less to Dahabiehs } \\
\text { generally, some being larger and unable to pass the } \\
\text { first cararact, others again being made smaller; } \\
\text { some fitted up for two persons only, and others to } \\
\text { accommodate a party of eight. In the Rahlehs and } \\
\text { Canjias, the cabins are plain, and general destitute } \\
\text { of ornament, they seldom also consist of more than } \\
\text { three apartments. They are used for the conveyance } \\
\text { of goods, and are frequently so dirty, or so infested } \\
\text { with vermin as to require to be sunk, before being } \\
\text { fitted to receive European travellers. }\end{array}$ \\
$\begin{array}{ll}\text { Many of the ferry and fishing boats are made of } \\
\text { multitudes of pieces of Acacia wood, which are } \\
\text { sewn or pegged together like a piece of Mosaic } \\
\text { work, and have the interstices filled with Nile mud. }\end{array}$ \\
\begin{tabular}{l} 
J.D. \\
\hline NOTES
\end{tabular} \\
$\begin{array}{l}\text { Image from AMC, Photographic Views Taken in } \\
\text { Nubia. }\end{array}$ \\
\hline
\end{tabular}

\begin{tabular}{|l|l|}
\hline IMAGE & \\
& \\
& \\
& \\
\hline TITLE & \\
\hline MEDIUM & \\
\hline CONCORDANCE & Philæ- From the North [Philæ. (From the North.)] \\
\hline & Albumen print from waxed paper negative \\
\hline & AMC, Photographic Views in Egypt \& Nubia \\
& $21.5 \times 27.7 \mathrm{~cm}$ \\
& AMC, Photographic Views Taken in Nubia \\
& $19.5 \times 27.2 \mathrm{~cm}$ \\
& British Library \\
$21.1 \times 26.9 \mathrm{~cm}$ \\
Université Laval \\
$20.7 \times 26.3 \mathrm{~cm}$
\end{tabular}




\begin{tabular}{|c|c|}
\hline & $\begin{array}{l}\text { Wilbour Library of Egyptology } \\
21.8 \times 27 \mathrm{~cm}\end{array}$ \\
\hline TEXT & $\begin{array}{l}\text { PHILÆ. } \\
\text { (FROM THE NORTH.) } \\
\text { PHILÆ is a small rocky island in Nubia, about two } \\
\text { miles above the first cataract, and seven miles from } \\
\text { Assouan. Nothing can be imagined more } \\
\text { picturesque than the Island itself, situated in a } \\
\text { beautiful basin of water, formed by a slight } \\
\text { expansion of the Nile. This basin seems completely } \\
\text { land-locked by granite hills, which consist of huge } \\
\text { boulders of red or black granite, piled by some } \\
\text { convulsion of nature, one over another, to a height } \\
\text { of some hundreds of feet. These rocky masses } \\
\text { appear as if any little disturbance would precipitate } \\
\text { them into the River. No change, however, has } \\
\text { taken place in their position during the last twenty- } \\
\text { six centuries, as upon one of the largest boulders, } \\
\text { its face towards the Island has been levelled and } \\
\text { polished, and the Royal and Priestly Titles of } \\
\text { Psammaticus I. have been sculptured on its } \\
\text { surface. } \\
\text { J.D. }\end{array}$ \\
\hline NOTES & $\begin{array}{l}\text { Image from AMC, Photographic Views Taken in } \\
\text { Nubia. Universite Laval, AMC, Photographic } \\
\text { Views Taken in Nubia and AMC, Photographic } \\
\text { Views in Egypt \& Nubia all have the same } \\
\text { orientation while the Wilbour Library of } \\
\text { Egyptology has a laterally reversed orientation. }\end{array}$ \\
\hline
\end{tabular}

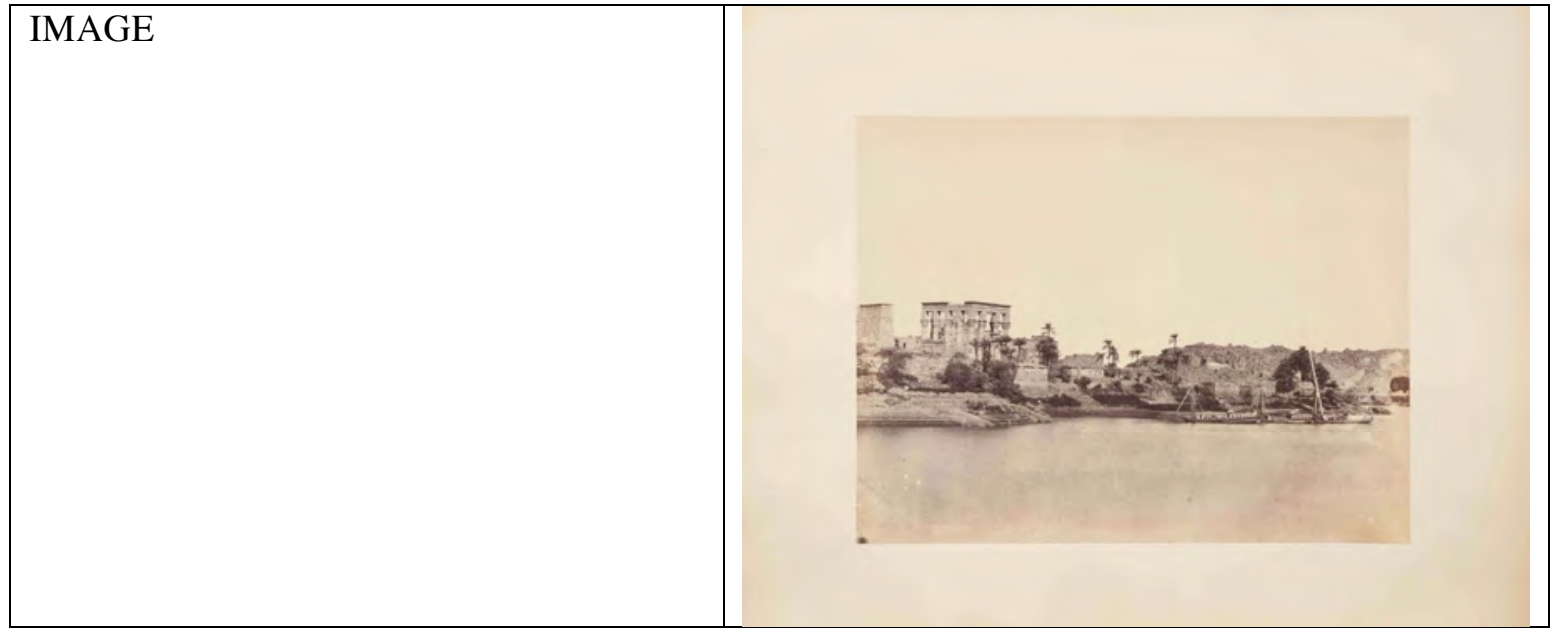




\begin{tabular}{|c|c|}
\hline TITLE & $\begin{array}{l}\text { Philæ- Dahabiehs [Philæ. (Dahabiehs- at the } \\
\text { Landing Place, under the Hypæthral Temple.)] }\end{array}$ \\
\hline MEDIUM & Albumen print from waxed paper negative \\
\hline CONCORDANCE & $\begin{array}{l}\text { AMC, Photographic Views in Egypt \& Nubia } \\
21.3 \text { x } 27.6 \mathrm{~cm} \\
\text { AMC, Photographic Views Taken in Egypt } \\
20.6 \text { x } 27.8 \mathrm{~cm} \\
\text { AMC, Photographic Views Taken in Nubia } \\
21.4 \text { x } 27.5 \mathrm{~cm} \\
\text { British Library } \\
21.5 \text { x } 27.4 \mathrm{~cm} \\
\text { Université Laval } \\
20.7 \text { x } 27.3 \mathrm{~cm} \\
\text { Wilbour Library of Egyptology } \\
21 \times 27.1 \mathrm{~cm}\end{array}$ \\
\hline TEXT & $\begin{array}{l}\text { PHILÆ. } \\
\text { (DAHABIEHS - AT THE LANDING PLACE, } \\
\text { UNDER THE HYPFTHRAL TEMPLE.) } \\
\text { ONE of these Nile boats is occupied by a party of } \\
\text { five English gentlemen, among them is a most } \\
\text { enthusiastic Stereoscopist. The other is occupied } \\
\text { by an English family in search of health for the } \\
\text { father, who is hopeless paralytic, but who } \\
\text { nevertheless is carried on a couch, from ruin to } \\
\text { ruin, by a party of his crew. } \\
\text { Among travellers in Egypt there are as great } \\
\text { diversities in country, in language, and in social } \\
\text { position, as there are in education, tastes, habits, } \\
\text { and objects in travel. } \\
\text { Many visit Egypt with cultivated minds, for the } \\
\text { purpose of viewing its wonderful monuments, } \\
\text { temples, palaces, and tombs and studying in these } \\
\text { their written books, the history, the religion, and } \\
\text { the manners of a people who had attained a high } \\
\text { position in literature, in arts, and in science some } \\
\text { thousands of years before Greece or Rome existed. } \\
\text { Some visit Egypt, who have taste, but whose } \\
\text { education and mental training have not prepared to } \\
\text { understand or to derive full advantage from what } \\
\text { they view in this, which is emphatically "A land of } \\
\text { wonders." Some visit Egypt in search of health, -- }\end{array}$ \\
\hline
\end{tabular}




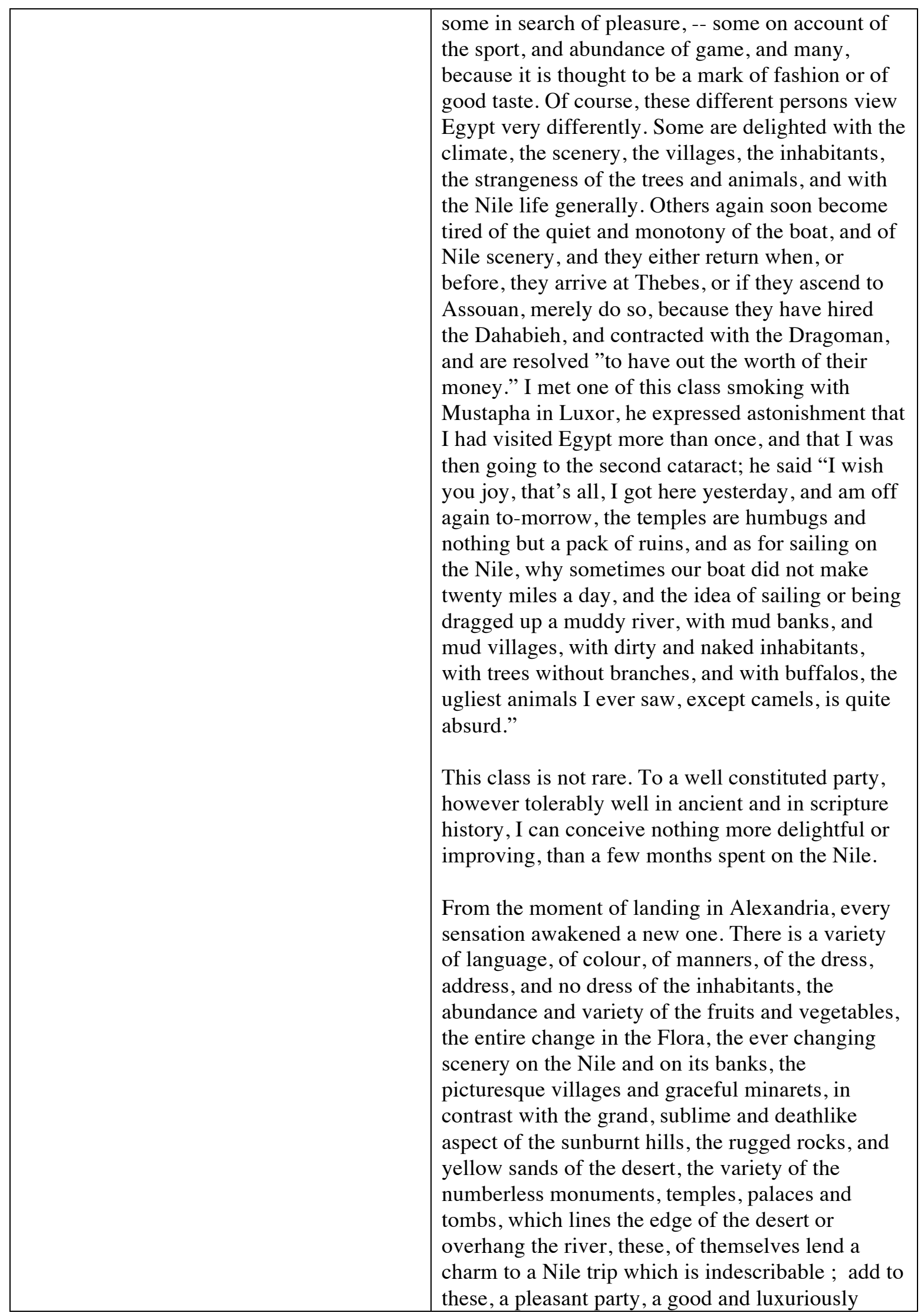




\begin{tabular}{|l|l|}
\hline & $\begin{array}{l}\text { fitted up Dahabieh, good servants, and excellent } \\
\text { cook, and cloudless skies. With a pleasant part of } \\
\text { ladies and gentlemen, an early breakfast, a stroll on } \\
\text { the banks of the river, or on the edge of the desert } \\
\text { for a couple of hours, a well selected library, } \\
\text { music, journalizing, chit-chat, and a comparison of } \\
\text { notes, make the days pass only too quickly. }\end{array}$ \\
$\begin{array}{l}\text { To young persons especially, before embarking on } \\
\text { the cares, trials and temptations of the world, } \\
\text { nothing can be more healthful or more improving } \\
\text { than a winter spent in Egypt and in southern Italy, } \\
\text { nothing more calculated to improve their tastes or } \\
\text { elevate their minds, and nothing more likely to } \\
\text { wean them from vain and frivolous pursuits and } \\
\text { amusements, and give them a relish for more } \\
\text { intellectual, more exalted, and more rational } \\
\text { pleasures. }\end{array}$ \\
\begin{tabular}{l} 
J.D. \\
\hline NOTES
\end{tabular} \\
$\begin{array}{l}\text { Image from AMC, Photographic Views Taken in } \\
\text { Nubia. The Université Laval has the print "Philæ- } \\
\text { Dahabiehs" alongside the text from "Philæ- } \\
\text { Hypæthral Temple". }\end{array}$ \\
\hline
\end{tabular}

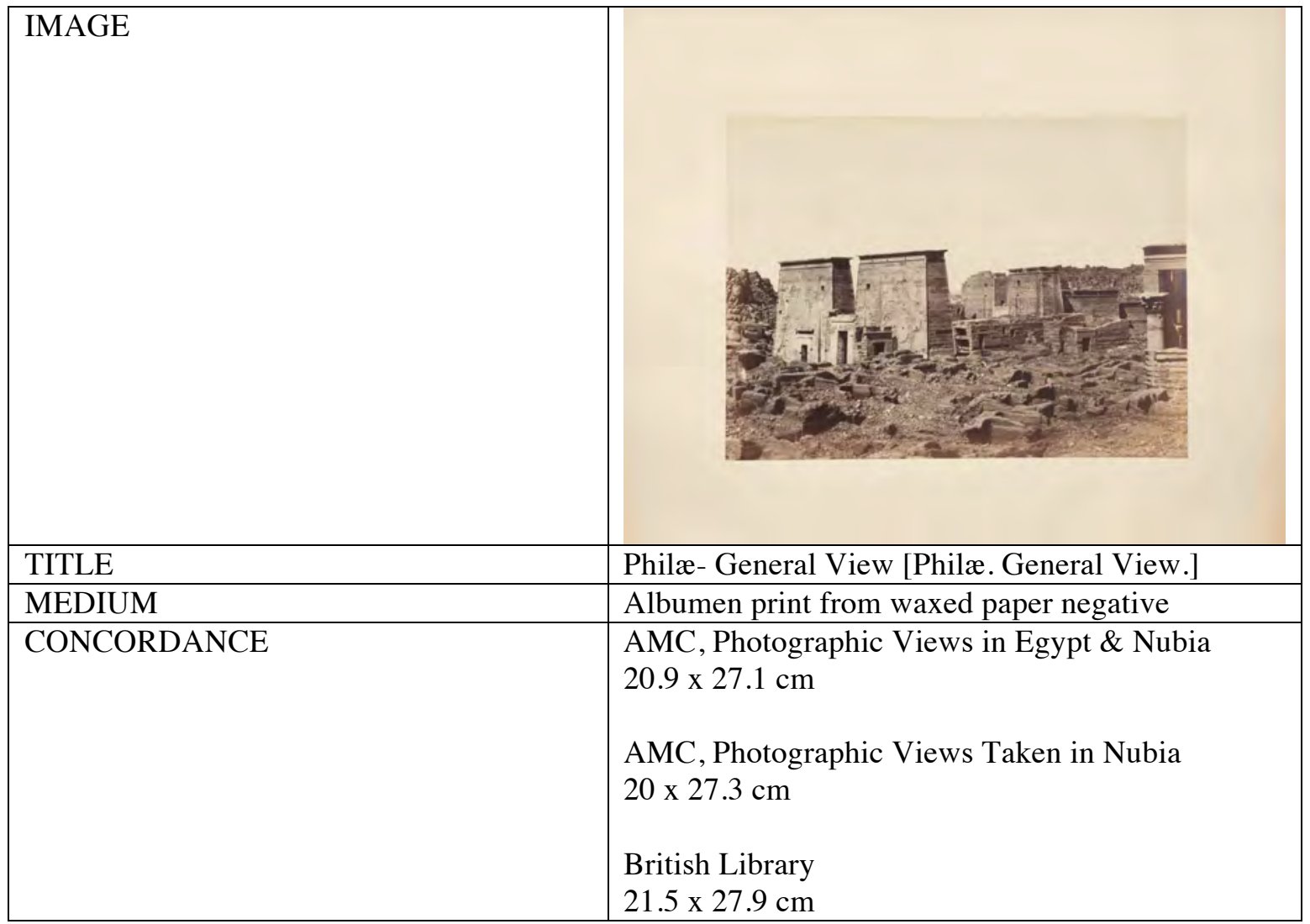




\begin{tabular}{|c|c|}
\hline & $\begin{array}{l}\text { Université Laval } \\
21 \times 26.9 \mathrm{~cm} \\
\text { Wilbour Library of Egyptology } \\
21.2 \times 27 \mathrm{~cm}\end{array}$ \\
\hline TEXT & $\begin{array}{l}\text { PHILÆ. } \\
\text { GENERAL VIEW. } \\
\text { THE ruins of ancient Temples are extensive and } \\
\text { beautiful. The principal Temple which was } \\
\text { dedicated to Isis, lines the western side, and } \\
\text { follows in its ground plan the irregularity of the } \\
\text { Island. To this it owes much of its beauty. The } \\
\text { oldest portions were built by Nectencbo of the } 30^{\text {th }} \\
\text { Dynasty, but they are insignificant in comparison } \\
\text { with the works of the Ptolemies and Cæsars. } \\
\text { Fergusson, speaking of the Temple of Isis, viz:-- } \\
\text { "No two of its buildings, scarcely any two walls, } \\
\text { are in the same axis or parallel to one another. No } \\
\text { Gothic architect in his wildest moments ever } \\
\text { played so freely with his lines and dimensions, and } \\
\text { none, it must be added, ever produced anything so } \\
\text { beautifully picturesque as this. It contains all the } \\
\text { play of light and shade, all the variety of Gothic } \\
\text { art, with the massiveness and grandeur of the } \\
\text { Egyptian style; and as it is still tolerably entire, and } \\
\text { retains much of its colour, there is no building out } \\
\text { of Thebes that gives so favourable an impression } \\
\text { of Egyptian art as this." The irregularity, however, } \\
\text { here sprang from a different cause to that which } \\
\text { occasioned the many gross departures from the } \\
\text { rules of symmetry in the Pharaonic Temples, as } \\
\text { this was built on the original plan, which } \\
\text { intentionally introduced them to suit the exigencies } \\
\text { of the situation. } \\
\text { A long Colonnade, the opposite sides of which } \\
\text { correspond neither in style nor proportions, leads } \\
\text { up to the principal Gateway, which is flanked by } \\
\text { propyleon Towers of a large size. This admits to an } \\
\text { Area, extremely irregular in its plan. The enclosing } \\
\text { wall on the right, to which is attached a covered } \\
\text { Colonnade, is the exterior wall of a small Temples } \\
\text { dedicated to Æ.sculapius, and that on the left, the } \\
\text { exterior wall of a row of curious dark chambers, } \\
\text { who purpose is not known. The rest of the main } \\
\text { Temple is tolerably regular. Other Towers-one of } \\
\text { which, with the ugly figures that decorate it, is }\end{array}$ \\
\hline
\end{tabular}




\begin{tabular}{|l|l|}
\hline & $\begin{array}{l}\text { seem in a following photograph-separate the } \\
\text { Area from the Portico. It is supported by 10 } \\
\text { columns, and is an extremely elegant specimen of } \\
\text { architecture: it is also peculiarly interesting as } \\
\text { illustrating the important use made of colour in } \\
\text { Egyptian architecture, and the brilliant effects } \\
\text { produced by it. The Chambers behind are small } \\
\text { and intricate in their ground plan, and, contrary to } \\
\text { the general custom, there are rooms above; the } \\
\text { important subjects sculptured on one of these are } \\
\text { described elsewhere. Not the least curious portion } \\
\text { of the Temple are the underground Passages and } \\
\text { Chambers, which are reached from the Portico, and } \\
\text { may have been employed for the concealment of } \\
\text { treasure, or perhaps far less innocent purposes. }\end{array}$ \\
$\begin{array}{ll}\text { J.D., JR. } \\
\text { NOTES }\end{array}$ & $\begin{array}{l}\text { Image from AMC, Photographic Views Taken in } \\
\text { Nubia. The Université Laval album displays the } \\
\text { print "Philæ- General View" alongside the text } \\
\text { "Philæ- From the South". }\end{array}$ \\
\hline
\end{tabular}

\begin{tabular}{|l|l|}
\hline IMAGE & \\
& \\
& \\
\hline TITLE & Philæ- Hypæthral Temple [Philæ. (Hypæthral \\
Temple.)
\end{tabular}




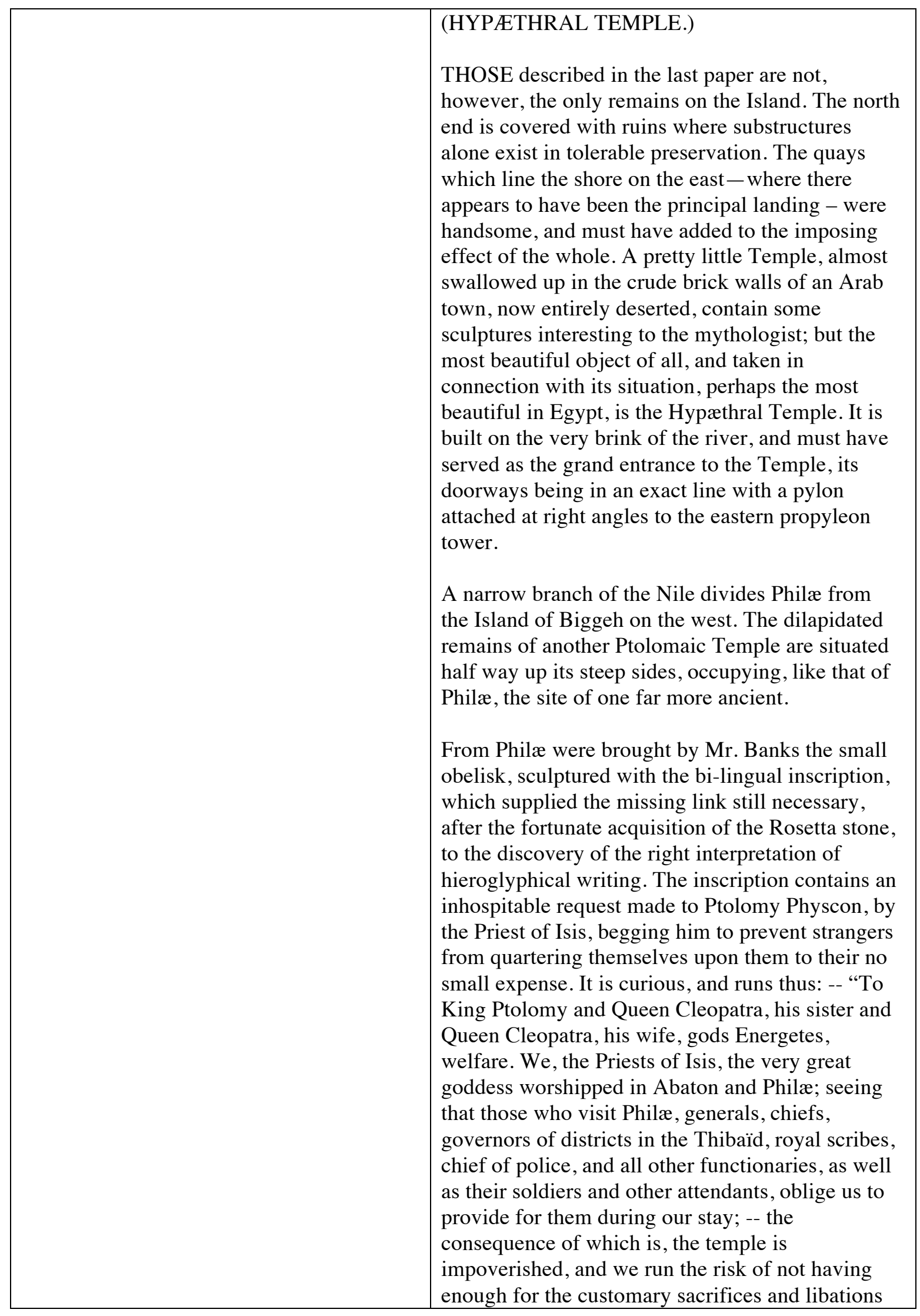




\begin{tabular}{|l|l|}
\hline & $\begin{array}{l}\text { offered for you and your children; do therefore } \\
\text { pray you, O great gods, if it seem right to you, to } \\
\text { order Numenius, your cousin and secretary, to } \\
\text { write Lochus, your cousin and governor of the } \\
\text { Thibaï, not to disturb us in this manner, and not to } \\
\text { allow any other person to do so, and to give us } \\
\text { authority to this effect; that we may put a stela } \\
\text { with an inscription commemorating your } \\
\text { beneficence toward us on this occasion, so that } \\
\text { your gracious favour may be recorded for ever; } \\
\text { which being done, we, and the Temple of Isis, shall } \\
\text { be indebted to you for this, among other favours. } \\
\text { Hail." }\end{array}$ \\
$\begin{array}{ll}\text { The permission was granted-and the stela } \\
\text { erected, to serve ultimately a very different } \\
\text { purpose to that which the Priests of Isis } \\
\text { contemplated. }\end{array}$ \\
\begin{tabular}{l} 
J.D., JR. \\
\hline NOTES
\end{tabular} \\
$\begin{array}{l}\text { Image from AMC, Photographic Views Taken in } \\
\text { Nubia. The Université Laval has the print "Philæ- } \\
\text { Dahabiehs" alongside the text from "Philæ- } \\
\text { Hypæthral Temple". }\end{array}$ \\
\hline
\end{tabular}

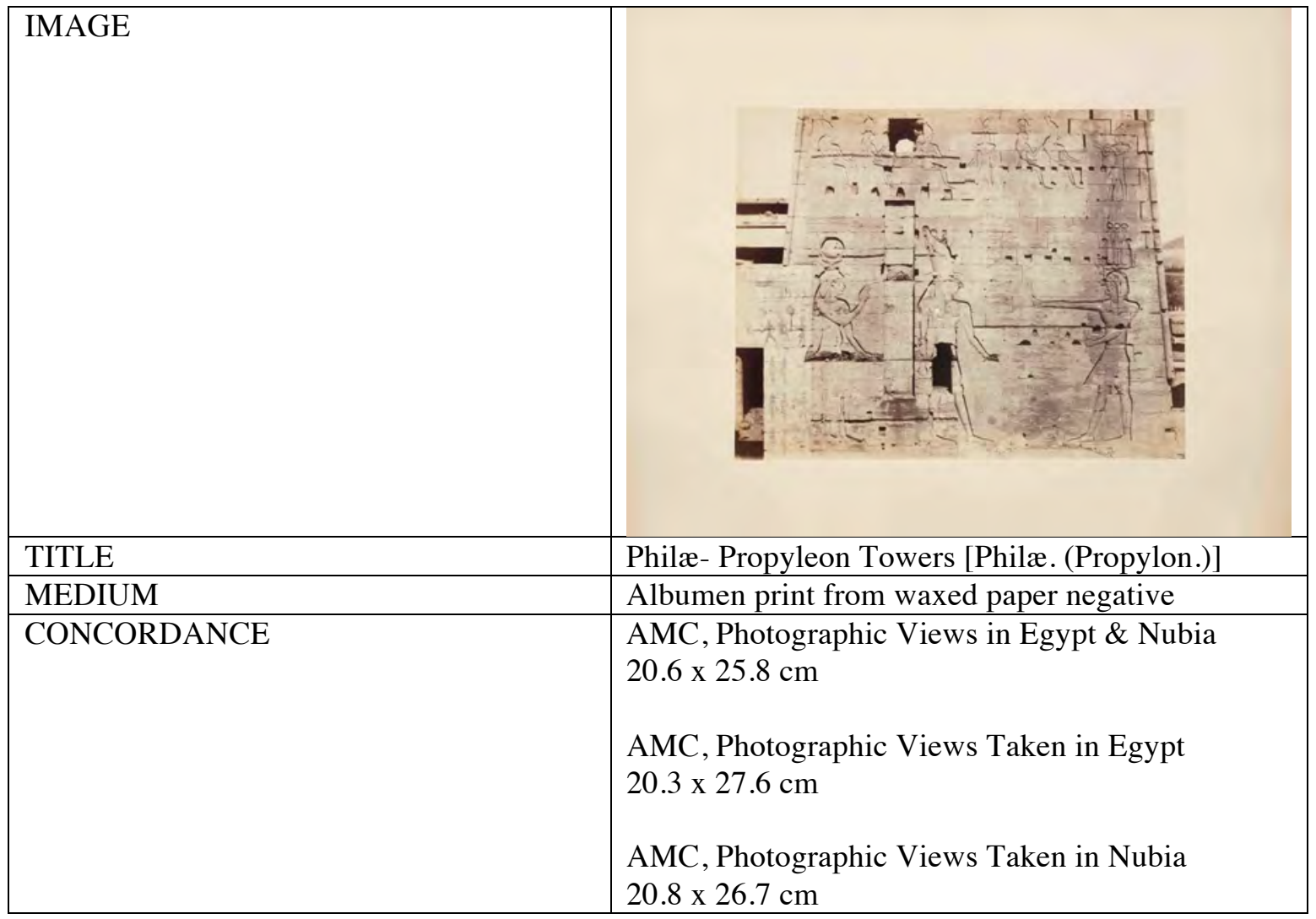




\begin{tabular}{|c|c|}
\hline & $\begin{array}{l}\text { British Library } \\
21.4 \times 26.7 \mathrm{~cm} \\
\text { Wilbour Library of Egyptology } \\
21.6 \times 27 \mathrm{~cm}\end{array}$ \\
\hline TEXT & $\begin{array}{l}\text { PHILÆ. } \\
\text { (PROPYLON.) } \\
\text { ON the top of one of the Towers is a small } \\
\text { chamber which opens on the roof of the Temple. It } \\
\text { is about } 12 \text { feet by } 8 \text {, it has no window, and the } \\
\text { only light it receives is from the doorway; it is } \\
\text { nevertheless most elaborately sculptured with } \\
\text { religious subjects, principally with scenes } \\
\text { representing the Sickness and Death of Osiris-the } \\
\text { Embalming of his Body -its Laying in State-its } \\
\text { transport to the Lower Regions by the Four } \\
\text { Genii-its reception of the Sacred Beard, by } \\
\text { Anubis-its presentation to himself, as the Judge } \\
\text { of the Dead, in the hall of Amenti-and its funeral } \\
\text { obsequies, attended by a procession of the different } \\
\text { Deities These scenes or representations are on } \\
\text { separate tablets, and extend in one line over three } \\
\text { sides of the chamber. There are several others, } \\
\text { unconnected with Osiris; one, in particular, is } \\
\text { interesting, as being a pictorial representation of } \\
\text { the "Fall of Man," it also is on a separate tablet, } \\
\text { about } 15 \text { inches by } 12 \text {, with a heavy and } \\
\text { ornamental plinth, supported by columns with } \\
\text { Lotus flower capitals. The sculptures represent two } \\
\text { figures, a man and a woman, watering a } \\
\text { pomegranate tree, with a serpent standing erect } \\
\text { addressing the female, who holds in her hand the } \\
\text { sacred Tau, or the symbol of eternal life. A row of } \\
\text { hieroglyphics over the figures has been translated } \\
\text { by the Rev. C. Foster, of Canterbury, in his work } \\
\text { on the "One Primeval Language," and the sense is } \\
\text { in exact accordance with the tradition in the first } \\
\text { book of Moses. The remains and inscriptions on } \\
\text { this and on the neighbouring island of Biggeh, } \\
\text { shew that Temples had been built here before the } \\
\text { soujourn of the Isrealites in Egypt. As these } \\
\text { Temples had been rebuilt or restored during the } \\
\text { Ptolemaic period it is more than probable that the } \\
\text { tradition of the Fall had been received from the } \\
\text { Jews, either during their captivity, or during the } \\
\text { many centuries of the constant intercourse which } \\
\text { existed between them and the Egyptians, from the } \\
\text { time of Exodus, until the Roman dominion in }\end{array}$ \\
\hline
\end{tabular}




\begin{tabular}{|l|l|}
\hline & Egypt. \\
& J.D. \\
\hline NOTES & $\begin{array}{l}\text { Image from AMC, Photographic Views Taken in } \\
\text { Nubia. }\end{array}$ \\
\hline
\end{tabular}

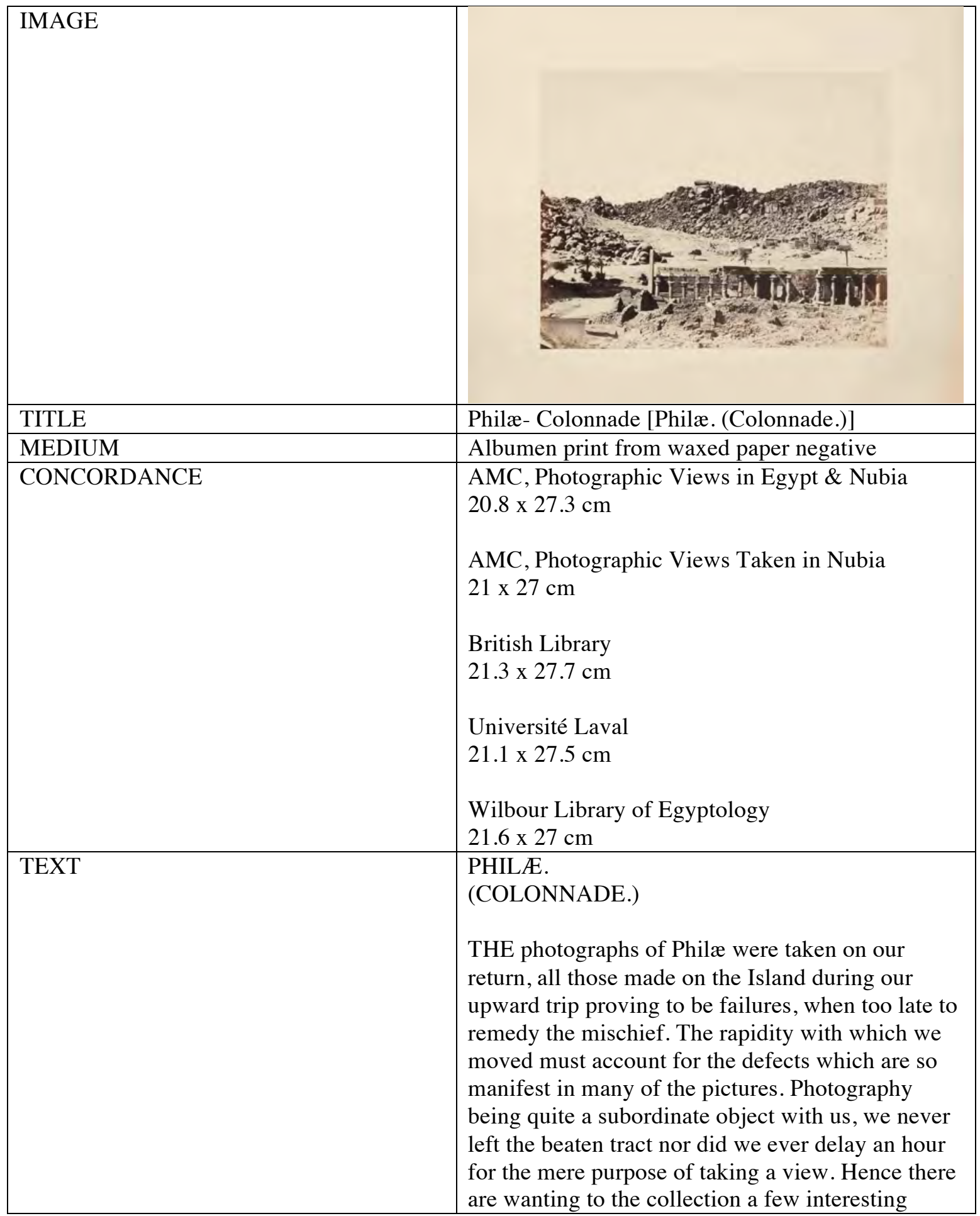




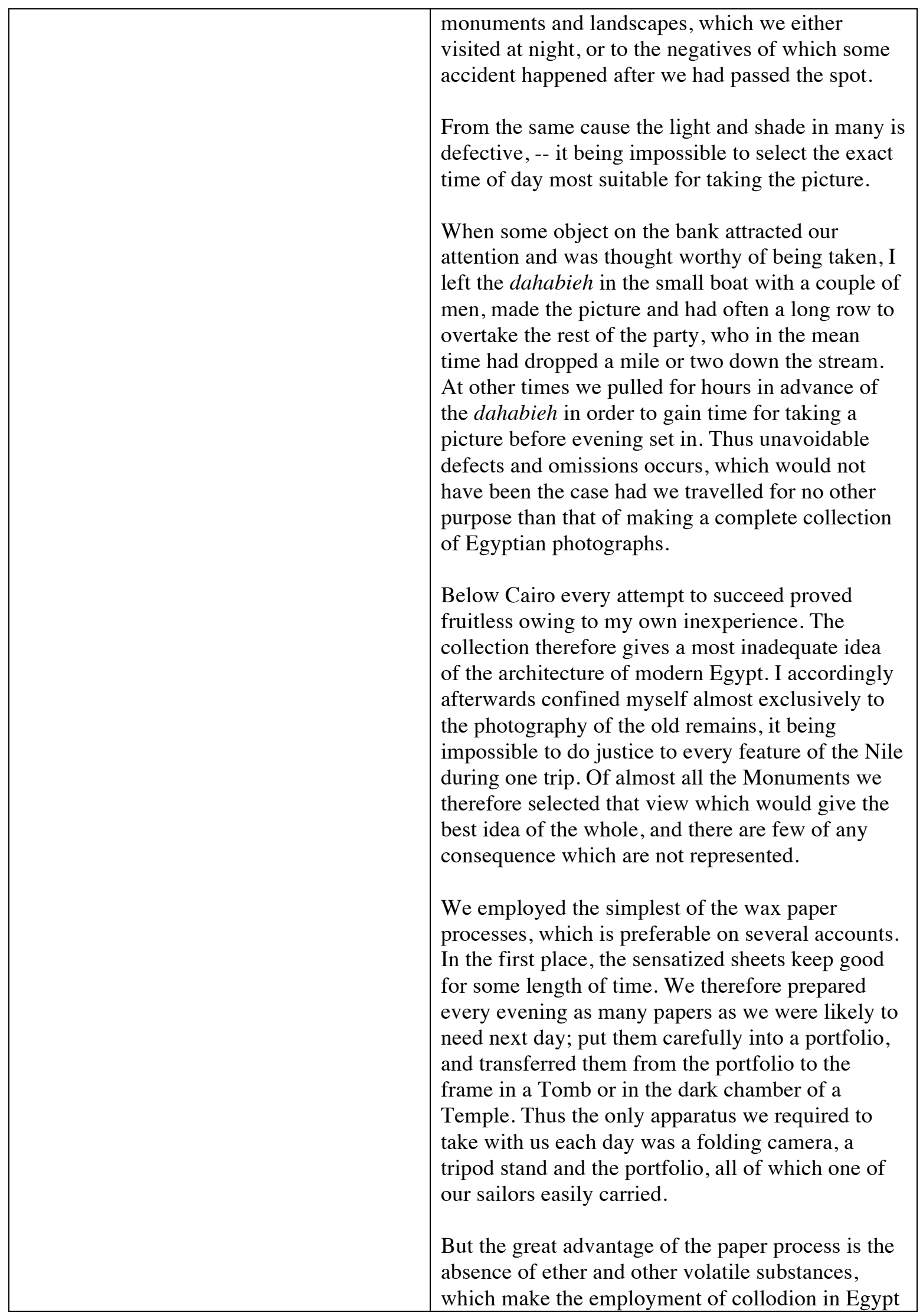




\begin{tabular}{|l|l|}
\hline & $\begin{array}{l}\text { almost impossible, and most painful from the rapid } \\
\text { evaporation caused by the intense heat and dryness } \\
\text { of the climate. }\end{array}$ \\
J.D., JR. \\
\hline NOTES & $\begin{array}{l}\text { Image from AMC, Photographic Views Taken in } \\
\text { Nubia. }\end{array}$ \\
\hline
\end{tabular}

\begin{tabular}{|c|c|}
\hline IMAGE & \\
\hline TITLE & Philæ- From the South [Philæ. (From the South.)] \\
\hline MEDIUM & Albumen print from waxed paper negative \\
\hline CONCORDANCE & $\begin{array}{l}\text { AMC, Photographic Views Taken in Nubia } \\
21.7 \times 27 \mathrm{~cm} \\
\text { British Library } \\
21.1 \times 27.1 \mathrm{~cm} \\
\text { Wilbour Library of Egyptology } \\
21.9 \times 27 \mathrm{~cm}\end{array}$ \\
\hline TEXT & $\begin{array}{l}\text { PHILÆ. } \\
\text { (FROM THE SOUTH.) } \\
\text { IT is difficult to decide from what point of view of } \\
\text { Philæ is most beautiful; whether from the north, } \\
\text { where the Island, apparently covered with ruins, is } \\
\text { seen through the beetling cliffs of granite boulders, } \\
\text { which here contract the Nile to half its usual } \\
\text { breadth; or form the east, where the graceful } \\
\text { hypæthral Temple stands out in most pleasing } \\
\text { contrast to the dead walls and massive proportions } \\
\text { of the principal Temple; or from the south, where } \\
\text { perhaps a better idea of its former architectural } \\
\text { magnificence can be obtained than from any other } \\
\text { quarter. Viewed from any side, and at any time, it } \\
\text { is exquisitely picturesque,-- more so, I doubt not, }\end{array}$ \\
\hline
\end{tabular}




\begin{tabular}{|l|l|}
\hline & $\begin{array}{l}\text { than when its quays were perfect, and cased the } \\
\text { banks which are now heaped up with their ruined } \\
\text { materials, and when the Temple with this huge } \\
\text { propyla and high unbroken walls rose from its well } \\
\text { paved surface. Then it must have been artistically } \\
\text { grand,-- one of the most imposing architectural } \\
\text { groups on the face of the earth; that character it has } \\
\text { now lost, but it has gained in other respects, and } \\
\text { looks more in harmony with the rugged and } \\
\text { desolate landscape amidst which it stands, and of } \\
\text { which it forms so intrinsic a part. }\end{array}$ \\
& \begin{tabular}{l} 
J.D., JR. \\
\hline NOTES
\end{tabular} \\
$\begin{array}{l}\text { Image from AMC, Photographic Views Taken in } \\
\text { Nubia. As previously mentioned, the Université } \\
\text { Laval album displays the print "Philæ- General } \\
\text { View" alongside the text "Philæ- From the South". }\end{array}$ \\
\hline
\end{tabular}

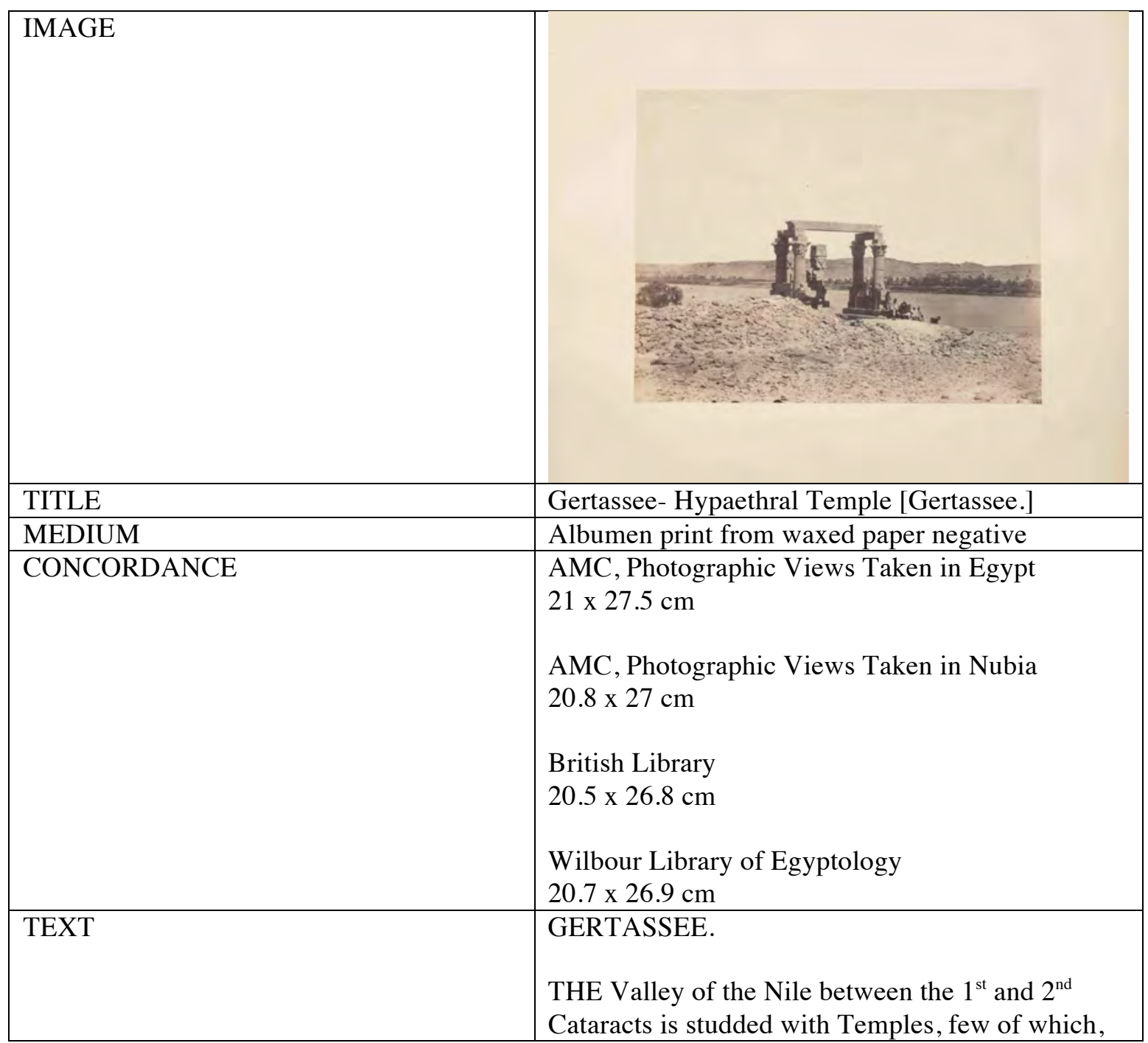




\begin{tabular}{|c|c|}
\hline & $\begin{array}{l}\text { however, are of great interest: but, being well } \\
\text { situated, they add much to the picturesqueness of } \\
\text { the landscape. About twelve miles above Philæ, at } \\
\text { Dabod, is a well preserved Temple, founded by an } \\
\text { Ethiopian monarch and added to by several of the } \\
\text { Ptolemaic and the Roman Emperors, but } \\
\text { remarkable neither in its arrangements nor its } \\
\text { decorations; and a few miles further up stands the } \\
\text { hypæthral Temple of Gertassee. It is placed on the } \\
\text { very brink of a steep hill, and from the beauty of its } \\
\text { situation excites expectation, when looked at from } \\
\text { the river, which a nearer inspection does not } \\
\text { realize. Only six columns remain, and two of them } \\
\text { are of that fantastical order met with at Dendera } \\
\text { and peculiar to the architecture of the later periods. } \\
\text { The sculptures are extremely rough, and the } \\
\text { proportions of the whole building bad. } \\
\text { The group seated on the platform had gathered } \\
\text { round us for the purpose of forcing on us the } \\
\text { purchase of a lamb. The inhabitants of this whole } \\
\text { region have a reputation for being quarrelsome and } \\
\text { ill-tempered. They are generally armed, and } \\
\text { judging from their appearance, would stand no } \\
\text { trifling. Some carry guns, but the most common } \\
\text { weapon is the sheathed knife belted round the } \\
\text { waist. } \\
\text { N.D. }\end{array}$ \\
\hline NOTES & $\begin{array}{l}\text { Image from AMC, Photographic Views Taken in } \\
\text { Nubia. The AMC, Photographic Views Taken in } \\
\text { Nubia and Wilbour Library of Egyptology albums } \\
\text { have the same orientation of this image, while the } \\
\text { image in AMC, Photographic Views Taken in } \\
\text { Egypt is laterally reversed. }\end{array}$ \\
\hline
\end{tabular}









\begin{tabular}{|l|l|}
\hline & $\begin{array}{l}\text { different Mosques, and certainly the whole of the } \\
\text { Alabaster of which the splendid Mosque of } \\
\text { Mahomet Ali, in the Citadel, has been entirely } \\
\text { constructed. }\end{array}$ \\
$\begin{array}{ll}\text { There are innumerable limestone Quarries along } \\
\text { the banks of the Nile, as far as Edfoo, where the } \\
\text { limestone disappears and sandstone takes its place. }\end{array}$ \\
$\begin{array}{l}\text { From this, as far as the second cataract, the } \\
\text { sandstone and granite alternate. About Assouan, } \\
\text { the first cataract, Philæ, and as far as Kalabshe, the } \\
\text { granite predominates; above Kalabshe sometimes } \\
\text { andstone and sometimes granite. Here and there, } \\
\text { on the elevated plateau of the Desert, I saw thin } \\
\text { deposits of limestone of very impure quality. }\end{array}$ \\
\begin{tabular}{ll} 
J.D. \\
\hline NOTES
\end{tabular} & $\begin{array}{l}\text { Image from AMC, Photographic Views Taken in } \\
\text { Nubia. }\end{array}$ \\
\hline
\end{tabular}

\begin{tabular}{|l|l|}
\hline IMAGE & \\
& \\
& \\
\hline TITLE & \\
\hline MEDIUM & Tafa [Tafa.] \\
\hline CONCORDANCE & Albumen print from waxed paper negative \\
\hline AMC, Photographic Views in Egypt \& Nubia \\
$21.1 \times 27.8 \mathrm{~cm}$ \\
AMC, Photographic Views Taken in Egypt \\
$21.4 \times 27.5 \mathrm{~cm}$ \\
AMC, Photographic Views Taken in Nubia \\
$21.5 \times 27.5 \mathrm{~cm}$ \\
British Library \\
$20.9 \times 27.6 \mathrm{~cm}$ \\
Université Laval \\
\hline
\end{tabular}




\begin{tabular}{|c|c|}
\hline & $\begin{array}{l}22 \times 27.6 \mathrm{~cm} \\
\text { Wilbour Library of Egyptology } \\
21.8 \times 27 \mathrm{~cm}\end{array}$ \\
\hline TEXT & $\begin{array}{l}\text { TAFA. } \\
\text { NOT many miles above Gertassee the valley } \\
\text { expands into a plain of considerable extent before } \\
\text { contracting again into a narrow gorge, where the } \\
\text { scenery more resembles that about Philæ than any } \\
\text { other part of the Nile. The sandstone gives place to } \\
\text { granite, which rises in huge black piles out of the } \\
\text { water and divides the river into a dozen channels. } \\
\text { The current rushes furiously among these rocky } \\
\text { islands, and is made the more impetus by the } \\
\text { sudden diminution in the breadth of the river. } \\
\text { This plain is strewn with remains of a late date and } \\
\text { to which it is difficult to assign any use. They are } \\
\text { stone enclosures, entered by a gateway and } \\
\text { sometimes divided into rooms, but always roofless. } \\
\text { They usually measure about } 22 \text { paces by } 18 \text {. Their } \\
\text { construction is curious, each row of stones being } \\
\text { higher at the centre than at the sides, and thus } \\
\text { presenting with the next a concave surface. } \\
\text { Possibly they were intended for rearing the sacred } \\
\text { animals. That they were devoted to religious } \\
\text { purposes is certain from the occurrence of } \\
\text { hieroglyphs and the figure of Isis on the Pylon of } \\
\text { one. } \\
\text { In the foreground of the picture is the ruin of a } \\
\text { small Temple, and at some distance to the right is } \\
\text { seen another. Neither is of great antiquity. The first } \\
\text { is rendered more interesting by the rude Christian } \\
\text { paintings with which its walls are decorated, than } \\
\text { by any merit of its own. } \\
\text { Christianity, viewing nothing as unclean in itself, } \\
\text { appropriated the ancient places of worship to its } \\
\text { own use; though the manner in which the } \\
\text { appropriation was often made and the violence } \\
\text { employed, especially where both parties were } \\
\text { numerous and their prejudices strong as in } \\
\text { Alexandria, redounded little to the credit of the } \\
\text { Christians. } \\
\text { J.D. }\end{array}$ \\
\hline NOTES & Image from AMC, Photographic Views in Egypt \& \\
\hline
\end{tabular}




\begin{tabular}{|l|l|}
\hline & Nubia. The Wilbour Library of Egyptology, the \\
AMC, Photographic Views in Egypt \& Nubia, the \\
AMC, Photographic Views Taken in Nubia and the \\
Université Laval albums all have the same \\
orientation of the image, while the AMC, \\
Photographic Views Taken in Egypt album has a \\
laterally reversed orientation of the image.
\end{tabular}

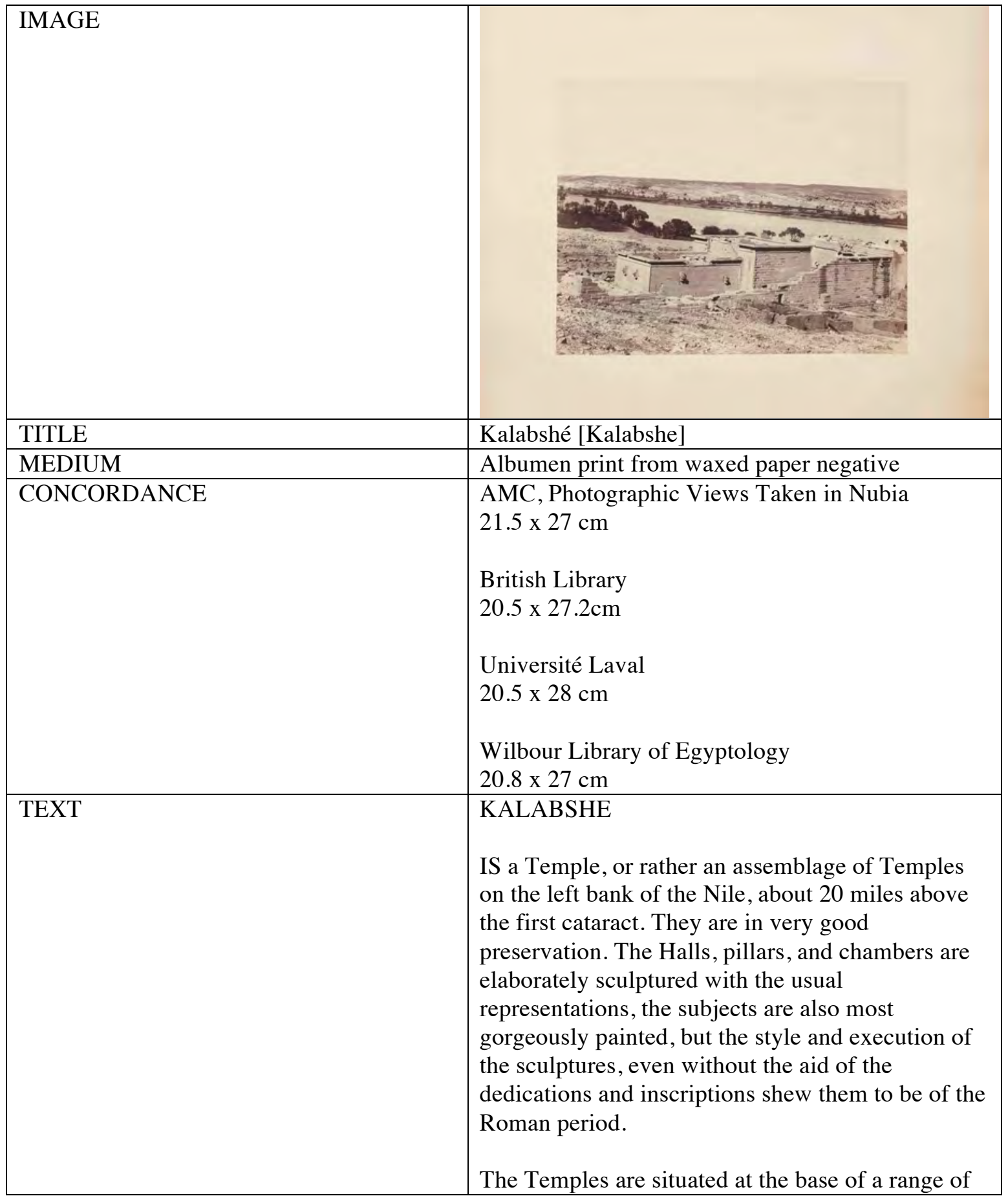




\begin{tabular}{|l|l|}
\hline & $\begin{array}{l}\text { sandstone hills, which here, as elsewhere in Nubia, } \\
\text { approach close to the bank of the river. These hills } \\
\text { are honeycombed with Tombs, most, if not all of } \\
\text { whom have been rifled, and their contents either } \\
\text { removed, or strewn about on the face of the hills. } \\
\text { The Tombs are very roughly cut, and I could } \\
\text { discover no date or inscription upon any of them. }\end{array}$ \\
$\begin{array}{l}\text { About a mile from the Main Temples, in a recess } \\
\text { of the hills, is a very small but very elegant rock } \\
\text { Temple excavated by Rameses II; the entrance, the } \\
\text { walls, the pillars, and the roof are very richly and } \\
\text { beautifully sculptured with representations of the } \\
\text { nations and peoples whom he has conquered, } \\
\text { bringing presents and tribute to him. The people } \\
\text { are of the black races, and the presents consist of } \\
\text { lions, ostriches, gold, apes, \&c. }\end{array}$ \\
$\begin{array}{l}\text { The execution of the hieroglyphics and sculptures } \\
\text { is spirited and fine, and they contrast very strongly } \\
\text { with those on the neighbouring Temples of } \\
\text { Kalabshe. }\end{array}$ \\
\hline NOTES
\end{tabular}

\begin{tabular}{|l|l|}
\hline IMAGE & \\
& \\
& \\
\hline TITLE & \\
\hline MEDIUM & Dendoor [Dendoor.] \\
\hline CONCORDANCE & Albumen print from waxed paper negative \\
& $20 \mathrm{x}$ 27.5 cm \\
& AMC, Photographic Views Taken in Nubia \\
& $21.4 \mathrm{x} 26.5 \mathrm{~cm}$ \\
\hline
\end{tabular}




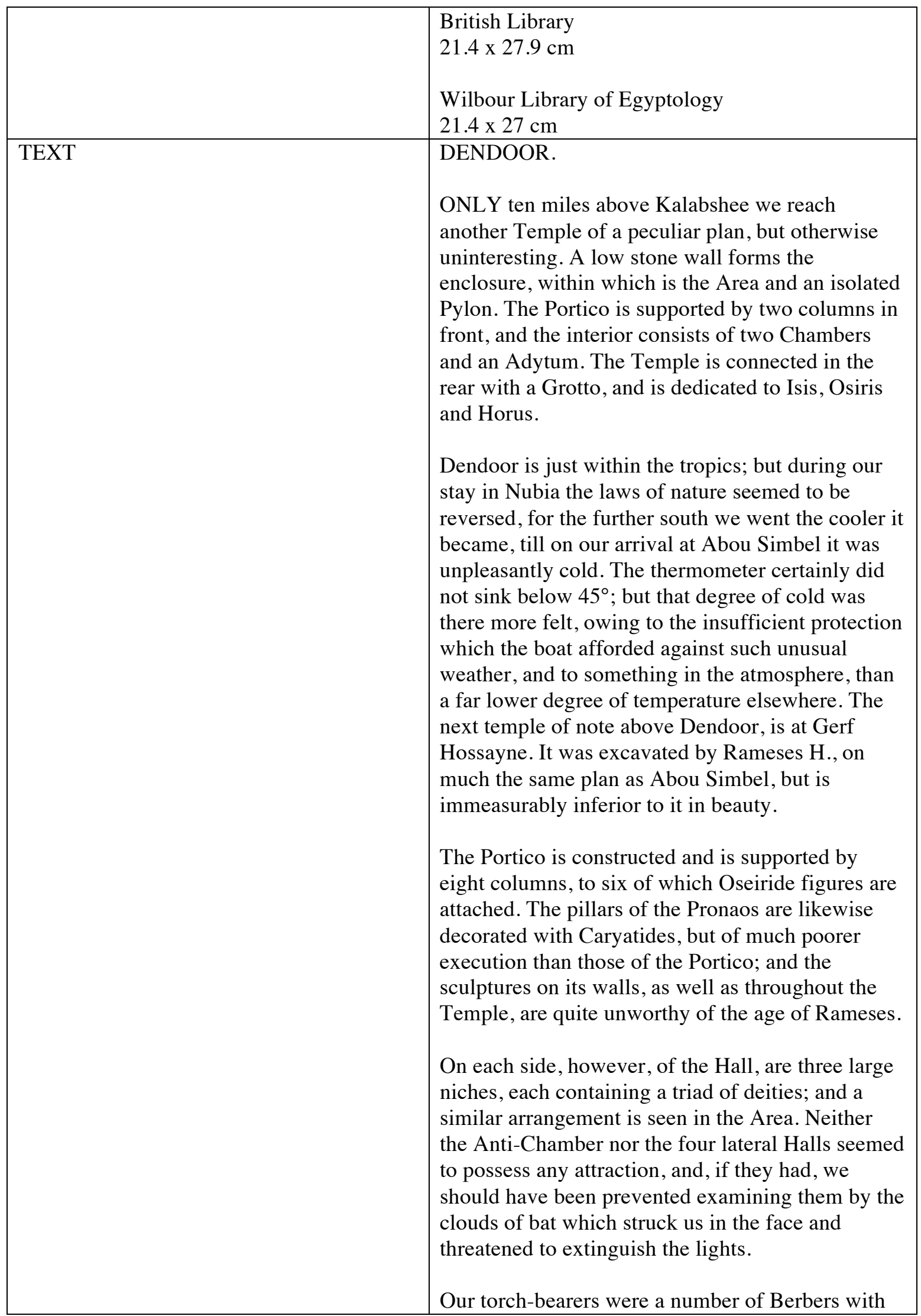




\begin{tabular}{|l|l|}
\hline & $\begin{array}{l}\text { burning rope-ends, who, on our departure, } \\
\text { besieged us for bucksheesh. Our only mode of } \\
\text { getting rid of them was by throwing what we } \\
\text { intended giving among them, when a general } \\
\text { scramble took place, and we were allowed to } \\
\text { depart in peace. Above the Cataract the hateful } \\
\text { word is ever sounding in our ears. Men and } \\
\text { women, old and young, join in the discordant } \\
\text { chorus. The baby's hand is held out by its mother } \\
\text { for a present, and little naked urchins roar out for } \\
\text { buchsheesh from the opposite side of the river, and } \\
\text { then laugh at their own act. }\end{array}$ \\
\begin{tabular}{ll} 
J.D. JR. \\
\hline NOTES
\end{tabular} & $\begin{array}{l}\text { Image from AMC, Photographic Views Taken in } \\
\text { Nubia. The image in the albums AMC, } \\
\text { Photographic Views Taken in Nubia and the } \\
\text { Wilbour Library of Egyptology have the same } \\
\text { orientation while the image in the album AMC, } \\
\text { Photographic Views Taken in Egypt is laterally } \\
\text { reversed. }\end{array}$ \\
\hline
\end{tabular}

\begin{tabular}{|l|l|}
\hline IMAGE & \\
& \\
& \\
\hline TITLE & \\
\hline MEDIUM & \\
\hline CONCORDANCE & Dakka [Dakkah.] \\
& Albumen print from waxed paper negative \\
& AMC, Photographic Views in Egypt \& Nubia \\
& $20.7 \times 27.6 \mathrm{~cm}$ \\
& AMC, Photographic Views Taken in Nubia \\
& $20.5 \mathrm{x} 27 \mathrm{~cm}$ \\
& British Library \\
$21.4 \times 27.9 \mathrm{~cm}$ \\
\\
\\
Université Laval \\
$21 \times 27.5 \mathrm{~cm}$ \\
\hline
\end{tabular}




\begin{tabular}{|c|c|}
\hline & $\begin{array}{l}\text { Wilbour Library of Egyptology } \\
21.4 \times 27 \mathrm{~cm}\end{array}$ \\
\hline TEXT & $\begin{array}{l}\text { DAKKAH. } \\
\text { A TEMPLE in Nubia, built or rather restored by } \\
\text { Ergamenes, an Ethiopian Monarch, who reigned } \\
\text { before the Christian Era. The sculptures and } \\
\text { paintings in this Temple are in excellent } \\
\text { preservation, and in their style and finish far } \\
\text { superior to what is commonly found in Temples of } \\
\text { so late a date. This, however, like almost all of the } \\
\text { Temples in Nubia, has been built on the site of a } \\
\text { much older one, probably of the period of the } 18^{\text {th }} \\
\text { dynasty, as the pavement of the approaches and of } \\
\text { the outer Court, as well as the substructions for the } \\
\text { obelisks and sphinxes are ancient. } \\
\text { The sculptures are remarkably well cut, and are in } \\
\text { high relief, they principally represent Ergamon and } \\
\text { his Queen in the act of adoration, or making } \\
\text { offerings to different deities. } \\
\text { The religion of Egypt, from the earliest } \\
\text { authenticated period, } 3500 \text { years, B.C., down to the } \\
\text { fourth century of our Era, seems to have undergone } \\
\text { no change, or to have been subject to few } \\
\text { innovations. Whatever changes took place in the } \\
\text { dynasties, and they were many, the worship of the } \\
\text { gods remained the same. Egypt, which had been } \\
\text { governed by native Pharaohs from times } \\
\text { immemorial, and which had been successively } \\
\text { conquered and governed by Ethiopians, by } \\
\text { Persians, by Greeks and Romans, still retained its } \\
\text { peculiar worship. From what we see of their works, } \\
\text { they adopted its religion and customs, and vied } \\
\text { with each other in the construction, reparation and } \\
\text { adornment of its Temples. } \\
\text { the gods; -- he then collected the Priests together, } \\
\text { and put them to death. } \\
\text { The rebuilding of this Temple of Dakkah, by } \\
\text { Ergamenes, proves that his denial of the supremacy } \\
\text { of the Priests did not lessen his respect for the } \\
\text { gods. Diodorus, the historian, who wrote B.C., } \\
\text { says: "It was the custome for the Priests, when } \\
\text { dissatisfied with the rule of the Ethiopian Kings, to } \\
\text { call upon them to destroy themselves, and that } \\
\text { that when so called upon, refused, saying } \\
\text { and }\end{array}$ \\
\hline
\end{tabular}




\begin{tabular}{|l|l|}
\hline & J.D. \\
\hline NOTES & $\begin{array}{l}\text { Image from AMC, Photographic Views Taken in } \\
\text { Nubia }\end{array}$ \\
\hline
\end{tabular}

\begin{tabular}{|c|c|}
\hline IMAGE & \\
\hline TITLE & Maharaka [Maharaka. (Temple.)] \\
\hline MEDIUM & Albumen print from waxed paper negative \\
\hline CONCORDANCE & $\begin{array}{l}\text { AMC, Photographic Views in Egypt \& Nubia } \\
19.9 \times 26.1 \mathrm{~cm} \\
\text { AMC, Photographic Views Taken in Nubia } \\
21.5 \times 27 \mathrm{~cm} \\
\text { British Library } \\
21.1 \times 26.6 \mathrm{~cm} \\
\text { Wilbour Library of Egyptology } \\
21.9 \times 27 \mathrm{~cm}\end{array}$ \\
\hline TEXT & $\begin{array}{l}\text { MAHARAKA. } \\
\text { (TEMPLE.) } \\
\text { THIS is one of the most picturesque remains in } \\
\text { Nubia, though never finished. It is hypæthral, and } \\
\text { of the Ptolemaic period. There are no sculptures or } \\
\text { paintings, a very rude representation of Isis, sitting } \\
\text { under the sacred fig tree, not deserving to be } \\
\text { mentioned. The columns are elegant, and they and } \\
\text { the screen are of the finest white sandstone. } \\
\text { As is often the case in Nubia, there are Christian } \\
\text { remains overlaying the more ancient. On a rough } \\
\text { ground of stucco are paintings of the Apostles, } \\
\text { which must once have decorated a Christian } \\
\text { church. The reason why these crumbling remains }\end{array}$ \\
\hline
\end{tabular}




\begin{tabular}{|l|l|}
\hline & $\begin{array}{l}\text { of Christianity are more numerous in Nubia than in } \\
\text { Egypt, is, that it kept its footing here much longer } \\
\text { than in the Lower Country. In 1673, the traveller } \\
\text { Wansleb mentioned, that the churches were still } \\
\text { standing, but closed for want of pastors. } \\
\text { N.D. }\end{array}$ \\
\hline NOTES & $\begin{array}{l}\text { Image from AMC, Photographic Views Taken in } \\
\text { Nubia. }\end{array}$ \\
\hline
\end{tabular}

\begin{tabular}{|c|c|}
\hline IMAGE & \\
\hline TITLE & Sabooa [Sabooa.] \\
\hline MEDIUM & Albumen print from waxed paper negative \\
\hline CONCORDANCE & $\begin{array}{l}\text { AMC, Photographic Views in Egypt \& Nubia } \\
21.8 \times 26.8 \mathrm{~cm} \\
\text { AMC, Photographic Views Taken in Nubia } \\
21.3 \times 27 \mathrm{~cm} \\
\text { British Library } \\
21 \times 27 \mathrm{~cm} \\
\text { Université Laval } \\
21.1 \times 27 \mathrm{~cm} \\
\text { Wilbour Library of Egyptology } \\
21.4 \times 26.4 \mathrm{~cm}\end{array}$ \\
\hline TEXT & $\begin{array}{l}\text { SABOOA. } \\
\text { AT Sabooa are the remains of a Temple of a time } \\
\text { at Rameses II. It is approached by a Dromos of } \\
\text { eight Androsphinxes, at the entrance of which } \\
\text { stand two Colossal Statues of the King. All but } \\
\text { four of the Sphinxes are covered with sand. The } \\
\text { propylon Towers are the only part in good }\end{array}$ \\
\hline
\end{tabular}




\begin{tabular}{|c|c|}
\hline & $\begin{array}{l}\text { preservation. The Area with its lateral corridors, } \\
\text { supported by } 8 \text { Osieride pillars, is almost full of } \\
\text { sand, and the entrance to the side chambers and } \\
\text { Naos are completely blocked up. We took a } \\
\text { photograph of the Towers, Sphinxes and Statues; } \\
\text { and the scene was enlivened by a Bedouin, a group } \\
\text { of children, Ramadan, and a stuffed crocodile, the } \\
\text { latter looking fierce enough to swallow up Temple } \\
\text { and all. } \\
\text { The people of Nubia leave a far more agreeable } \\
\text { impression on one's mind than the Egyptians. The } \\
\text { women when young are generally pretty, } \\
\text { sometimes attractively so; and this combined with } \\
\text { the beauty of their figures, and the gracefulness of } \\
\text { their every action, makes it often difficult to resist } \\
\text { their inopportune demands for a present. They } \\
\text { never wear the hateful yash-mack, nor do they } \\
\text { evince the slightest shyness, but laugh and talk } \\
\text { with strangers as familiarly as women of the North. } \\
\text { Would they but dispense with the castor-oil, which } \\
\text { unfortunately they apply in most wasteful } \\
\text { quantities to their hair and bodies, their society } \\
\text { would be much more agreeable. About Derr their } \\
\text { dress is peculiarly graceful, and shews off to } \\
\text { perfection their figures, which are tall, erect and } \\
\text { well proportioned. } \\
\text { The children of Nubia are likewise much less } \\
\text { repulsive than the Egyptians. They are often } \\
\text { bright-eyed, playful little creatures, as happy as the } \\
\text { day is long, and sporting about in nature's attire, } \\
\text { far more lustily than their better clad fellow- } \\
\text { mortals. The men are a splendid race, tall and well } \\
\text { built, with fine intelligent features and well } \\
\text { developed heads. The two tribes of Berbers, } \\
\text { however, which inhabit Nubia, are far less } \\
\text { handsome than some which live further south, } \\
\text { above Soudan and elsewhere. The few we saw of } \\
\text { them, accompanying the caravans from the interior } \\
\text { to Korusko, were perfect types of humanity. } \\
\text { N.D. }\end{array}$ \\
\hline NOTES & $\begin{array}{l}\text { Image from AMC, Photographic Views Taken in } \\
\text { Nubia. }\end{array}$ \\
\hline
\end{tabular}




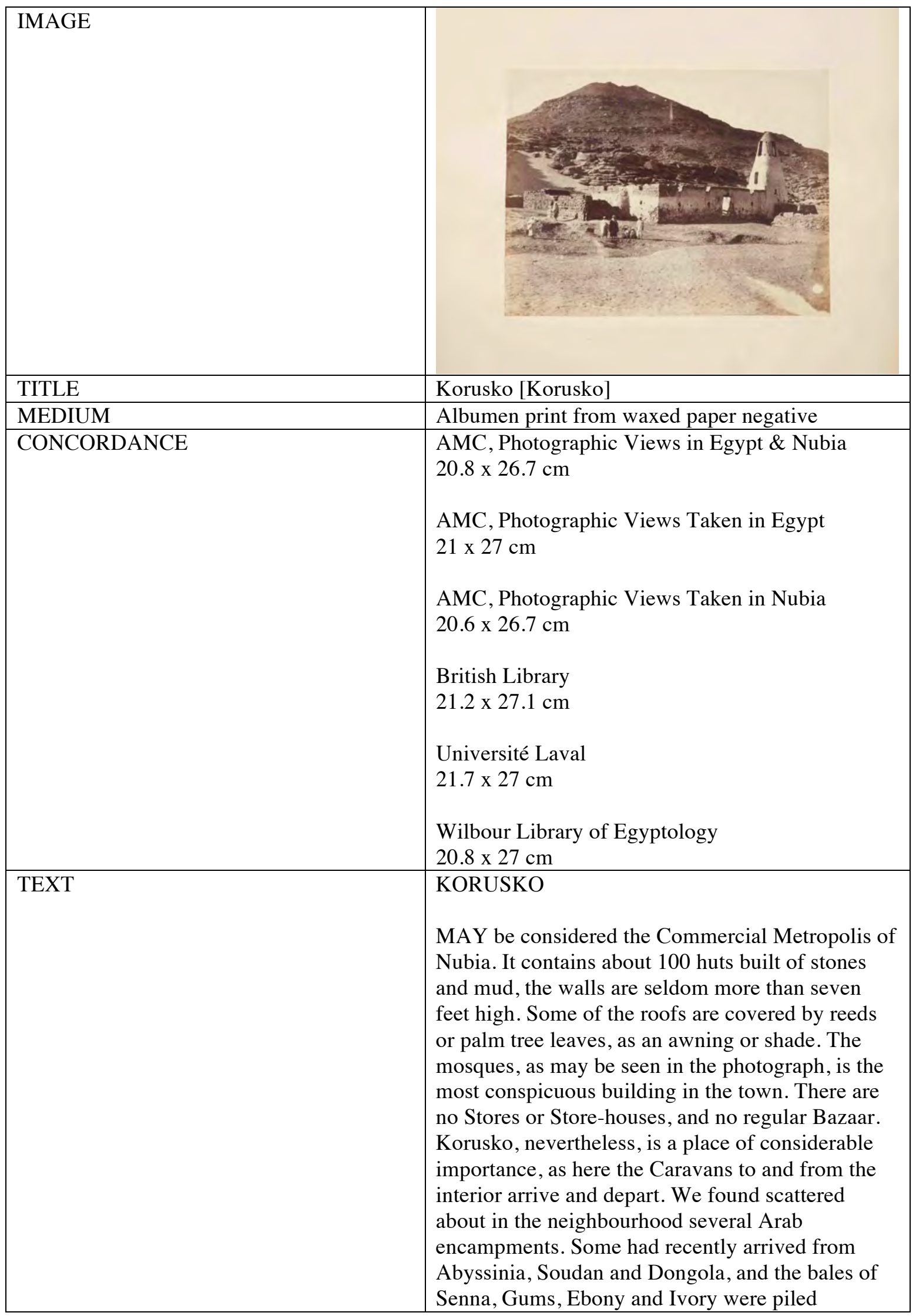




\begin{tabular}{|l|l|}
\hline & $\begin{array}{l}\text { together, waiting a Canjia to transport them to the } \\
\text { first cataract. Other Caravans seemed to have been } \\
\text { waiting a considerable time for a return load. } \\
\text { These Caravans, unlike the Haj, or those to the } \\
\text { Eastward and the Red Sea, have no fixed time for } \\
\text { arrival or departure; they also vary greatly in size. } \\
\text { Some, we observed, consisted of only six or eight } \\
\text { camels, others of thirty or forty. The owners and } \\
\text { conductors are Bedouins of the Senaar Tribe; they } \\
\text { are fine handsome men in figure, with regular and } \\
\text { well cut features, they are very dark, some of them } \\
\text { quite black; they go almost naked and wear no } \\
\text { head dress. The hair is long and is never cut; that } \\
\text { on the crown of the head is frizzed out into a huge } \\
\text { bush, the remainder is carefully plaited and } \\
\text { allowed to hang like a fringe round the head. The } \\
\text { whole is most abundantly anointed with grease and } \\
\text { castor oil. Whatever opinions may be formed of } \\
\text { the use or ornament of this practice, there can be } \\
\text { no difference as to its odour under a tropical Sun. }\end{array}$ \\
$\begin{array}{ll}\text { J.D. } \\
\text { NOTES }\end{array}$ \\
$\begin{array}{l}\text { Image from AMC, Photographic Views Taken in } \\
\text { Nubia. }\end{array}$ \\
\hline
\end{tabular}

\begin{tabular}{|l|l|}
\hline IMAGE & \\
& \\
& \\
& \\
\hline TITLE & \\
\hline MEDIUM & Caravan Road [Caravan Road from Korusko] \\
\hline CONCORDANCE & Albumen print from waxed paper negative \\
\hline & $\begin{array}{l}\text { AMC, Photographic Views Taken in Nubia } \\
21.1 \times 27 \mathrm{~cm}\end{array}$ \\
& British Library \\
$21.3 \times 25.8 \mathrm{~cm}$ \\
\\
Wilbour Library of Egyptology \\
$21.5 \times 26.9 \mathrm{~cm}$
\end{tabular}




\begin{tabular}{|c|c|}
\hline TEXT & 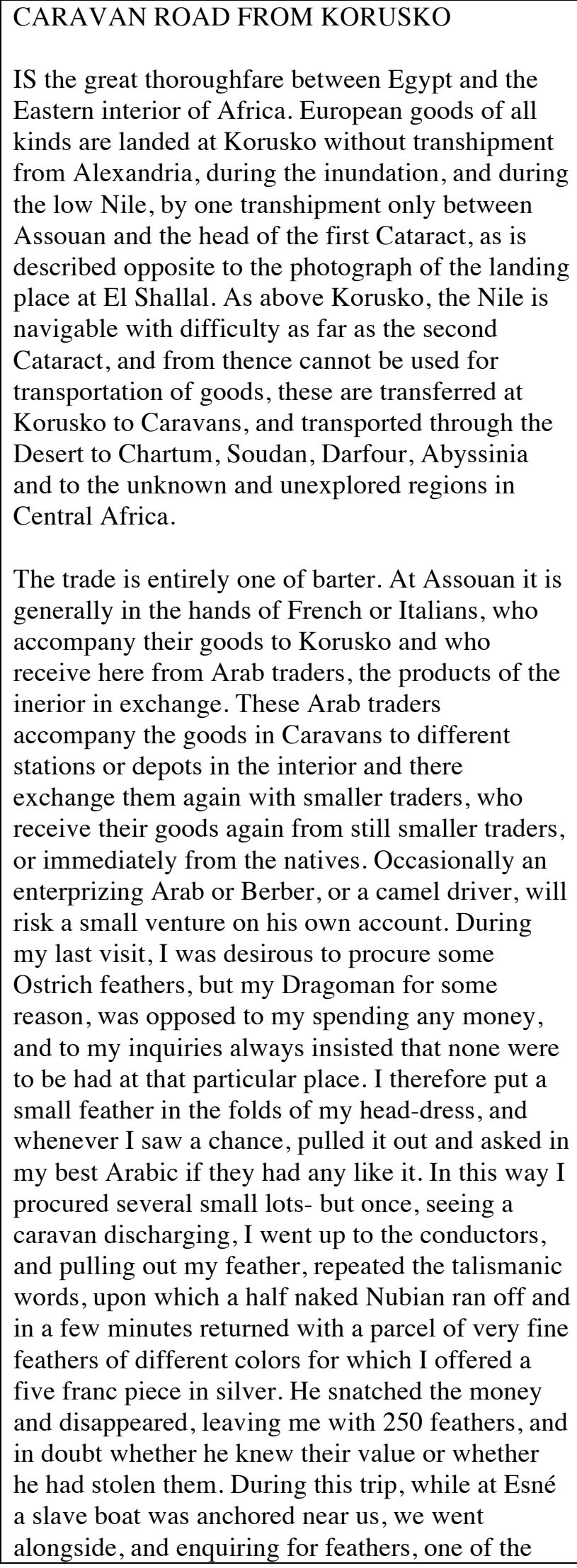 \\
\hline
\end{tabular}




\begin{tabular}{|c|c|}
\hline & $\begin{array}{l}\text { men produced a bag of very fine ones, but, as he } \\
\text { asked a dollar an ounce by weight, and as my idea } \\
\text { of their value was based upon my operation of the } \\
\text { last year, we declined to purchase, and had reason } \\
\text { afterwards to regret it; for although we obtained } \\
\text { some very good ones at Korusko and at Assouan, } \\
\text { they were not better, and very much dearer. } \\
\text { Besides the great Caravan road from Korusko, } \\
\text { several others leave the Nile for different routes. } \\
\text { One leaves Keneh for Cosseir conveying European } \\
\text { goods to the countries east of the Red Sea and } \\
\text { bringing back their products. One leaves Benisouf } \\
\text { for the Little Oasis, four days' journey across the } \\
\text { Desert. One leaves Osioot, and one leaves Thebes } \\
\text { for the Great Oasis. It was on this last route that the } \\
\text { army dispatched by Cambyses for the destruction } \\
\text { of the Temples of the Oasis, perished, at the same } \\
\text { time that his own army was nearly destroyed in the } \\
\text { attempt to reach Meroe. } \\
\text { In the words of Herodotus "Cambyses when he } \\
\text { passed through Thebes, detached from his main } \\
\text { body some fifty thousand men, and sent them } \\
\text { against the Ammonians, with orders to carry the } \\
\text { people into captivity and burn the Temple. The } \\
\text { men sent to attack the Ammonians started from } \\
\text { Thebes, having guides with them, and may be } \\
\text { clearly traced as far as the city Oasis (the small } \\
\text { Oasis), this place is distant from Thebes seven } \\
\text { days' journey across the sand, thus far, the army is } \\
\text { known to have made its way; but thenceforth } \\
\text { nothing is to be heard of them, except what the } \\
\text { Ammonians report. It is certain they neither } \\
\text { reached the Ammonians, nor ever came back to } \\
\text { Thebes. Further than this the Ammonians relate as } \\
\text { follows, that the Persians set forth from Oasis, } \\
\text { across the sand, and had reached about half way } \\
\text { between that place and themselves, when, as they } \\
\text { were at their mid-day meal, a wind arose from the } \\
\text { south strong and deadly, bringing with it vast } \\
\text { columns of whirling sand, which entirely covered } \\
\text { up the troops, and caused them wholly to } \\
\text { disappear, thus according to the Ammonians, did it } \\
\text { fare with this army." }\end{array}$ \\
\hline NOTES & $\begin{array}{l}\text { Image from AMC, Photographic Views Taken in } \\
\text { Nubia. }\end{array}$ \\
\hline
\end{tabular}




\begin{tabular}{|c|c|}
\hline \multicolumn{2}{|l|}{ IMAGE } \\
\hline & 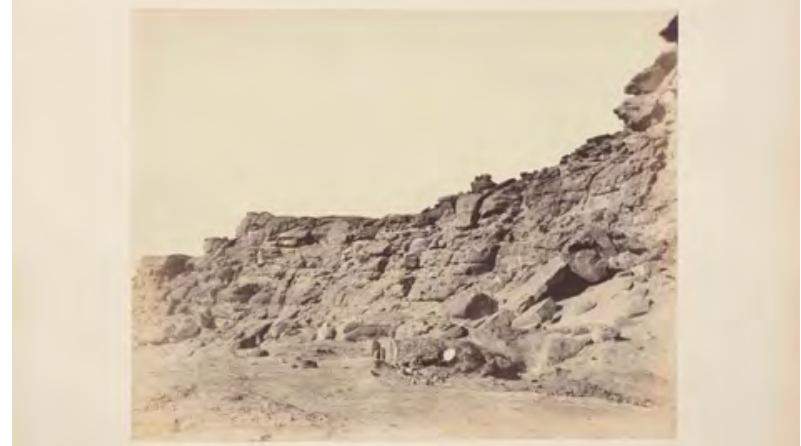 \\
\hline TITLE & Christian Graves [Christian Graves.] \\
\hline MEDIUM & Albumen print from waxed paper negative \\
\hline CONCORDANCE & $\begin{array}{l}\text { AMC, Photographic Views Taken in Egypt } \\
20.1 \times 27.5 \mathrm{~cm} \\
\text { AMC, Photographic Views Taken in Nubia } \\
21.2 \times 26.8 \mathrm{~cm} \\
\text { British Library } \\
20.9 \times 27.4 \mathrm{~cm} \\
\text { Université Laval } \\
19.9 \text { x } 26.5 \mathrm{~cm} \\
\text { Wilbour Library of Egyptology } \\
21.7 \times 26 \mathrm{~cm}\end{array}$ \\
\hline TEXT & $\begin{array}{l}\text { CHRISTIAN GRAVES. } \\
\text { THE Caravan Road from Korusko winds through a } \\
\text { valley, or rather through a rocky gorge among the } \\
\text { hills. It is at the base of one of these hills that } \\
\text { Korusko is situated, and at the mouth or entrance } \\
\text { of the gorge, and near the hill, that the caravans } \\
\text { receive or discharge their loads. Opposite to the } \\
\text { photograph of the first cataract, it is stated that } \\
\text { some thousands of years ago, a complete rocky } \\
\text { barrier had existed there, which had raised the Nile } \\
\text { in Nubia } 30 \text { or } 40 \text { feet above its present highest } \\
\text { level; at that period, this rocky valley or gorge, was } \\
\text { entirely under water; this proved by the water worn } \\
\text { appearance of the rocks, which plainly show the } \\
\text { influence of the periodical rise and fall of the } \\
\text { River; it is also proved by the beds of alluvium } \\
\text { which have been deposited here and there, at the }\end{array}$ \\
\hline
\end{tabular}




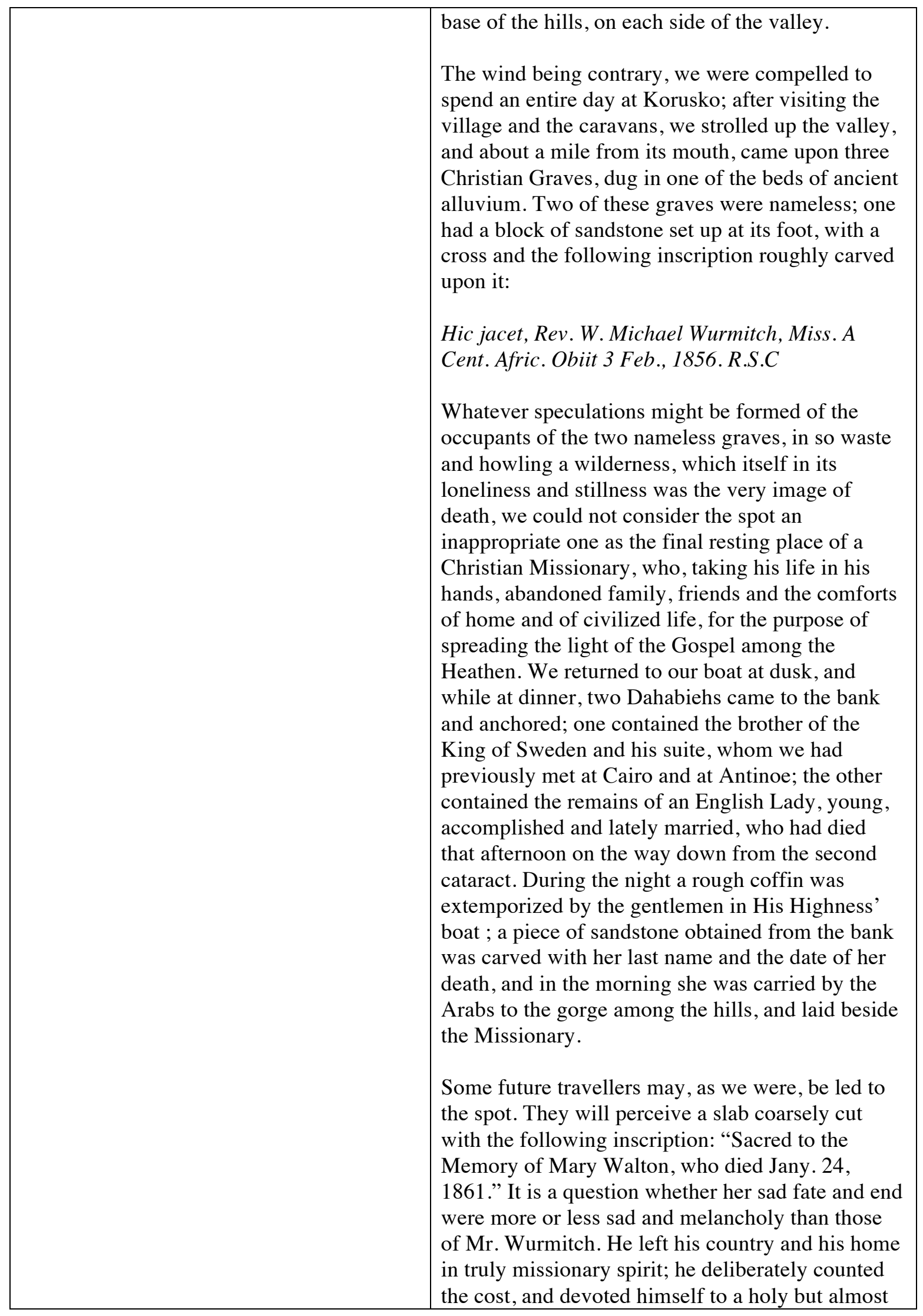




\begin{tabular}{|l|l|}
\hline $\begin{array}{l}\text { hopeless mission; he met a Missionary's death, and } \\
\text { was laid in a Missionary's grave. She, young, } \\
\text { amiable and talented left home and friends a happy } \\
\text { bride, with the prospect and hope of soon again } \\
\text { rejoining them. She died with no one but her } \\
\text { afflicted husband to solace her, or to close her } \\
\text { eyes, and was followed to her lonely, rocky and } \\
\text { desolate resting place by two or three gentlemen } \\
\text { who, until the evening before, were ignorant of her } \\
\text { name. } \\
\text { At that last dread moment, when the King of } \\
\text { terrors appears, he is surely met with more } \\
\text { fortitude and resignation when he approaches a } \\
\text { bedside surrounded by kind and sympathising } \\
\text { friends. } \\
\text { The photographs shews the rocky defile and the } \\
\text { mound of alluvium in which the four graves have } \\
\text { been dug; and by the aid of a glass, the inscriptions } \\
\text { on the slabs may easily be read. }\end{array}$ \\
\begin{tabular}{l} 
J.D. \\
\hline NOTES
\end{tabular} \\
$\begin{array}{l}\text { Image from AMC, Photographic Views Taken in } \\
\text { Nubia. }\end{array}$ \\
\hline
\end{tabular}

\begin{tabular}{|l|l|}
\hline IMAGE & \\
& \\
& \\
\hline TITLE & \\
\hline MEDIUM & Amada [Amada.] \\
\hline CONCORDANCE & Albumen print from waxed paper negative \\
& $20.6 \mathrm{x}$ 2 27.2 cm \\
& AMC, Photographic Views Taken in Nubia \\
& $20.9 \times 27$ cm \\
& British Library \\
\hline
\end{tabular}




\begin{tabular}{|c|c|}
\hline & $\begin{array}{l}21.1 \times 26.6 \mathrm{~cm} \\
\text { Wilbour Library of Egyptology } \\
21.8 \times 27 \mathrm{~cm}\end{array}$ \\
\hline TEXT & $\begin{array}{l}\text { AMADA. } \\
\text { A TEMPLE in Nubia, built, sculptured and painted } \\
\text { in the highest style of Egyptian Art, during the } 18^{\text {th }} \\
\text { Dynasty. It was built and dedicated by Thothmes } \\
\text { III. and IV. to Amum Ra, the Tutelary Divinity of } \\
\text { Thebes. It is one of the very few Temples in Nubia, } \\
\text { which has neither been rebuilt or added to by later } \\
\text { Pharaohs. With rare exceptions, all of the Temples } \\
\text { in Upper Egypt and Nubia have been rebuilt by } \\
\text { Monarchs of the Greek or Roman periods, on the } \\
\text { foundations of, and often with the materials of the } \\
\text { Temples built by Pharaohs of the old Monarchy, or } \\
\text { by those of the earlier periods of the new. } \\
\text { Amada is situated on the Sybian Desert, and high } \\
\text { above the Nile. It commands a very extensive view } \\
\text { of both the Sybian and Arabian Deserts, with the } \\
\text { River flowing calmly between them. There is no } \\
\text { trace of vegetation, excepting the narrow fringe of } \\
\text { green on the immediate edge of the River. } \\
\text { It will probably never be known why these } \\
\text { beautiful and costly Temples were built in } \\
\text { situations where there were no local means of } \\
\text { support for even the Priests who ministered in } \\
\text { them. } \\
\text { J.D. }\end{array}$ \\
\hline NOTES & $\begin{array}{l}\text { Image from AMC, Photographic Views Taken in } \\
\text { Egypt. In the AMC, Photographic Views Taken in } \\
\text { Nubia album, the top half of the man sitting on top } \\
\text { of the temple is absent. }\end{array}$ \\
\hline
\end{tabular}




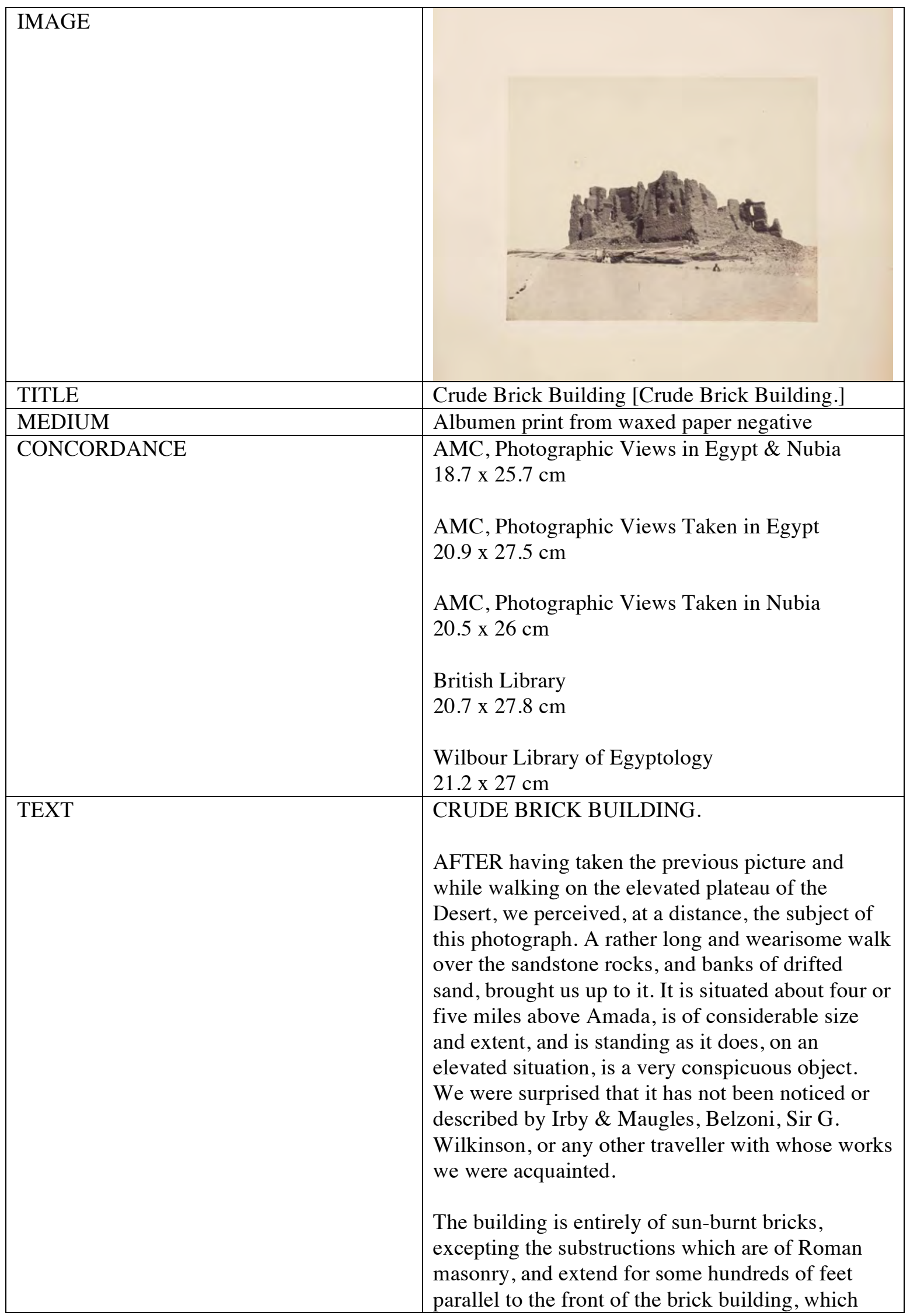




\begin{tabular}{|c|c|}
\hline & $\begin{array}{l}\text { itself is upwards of two hundred feet. } \\
\text { Looking at the foundations, it is a mere matter of } \\
\text { conjecture for what uses so large a building was } \\
\text { originally intended, particularly in such a situation. } \\
\text { The extent of the frontage, its uniform thickness, } \\
\text { the absence of ruins and of the mounds of rubbish } \\
\text { and pottery which always mark the sites of } \\
\text { Temples, shew that this was not its original design. } \\
\text { It is probable that it may have been one of the } \\
\text { permanent Roman camps, which they are known to } \\
\text { have possessed in Nubia, and that the Christians of } \\
\text { the third or fourth century had erected a Monastery } \\
\text { or some religious establishment upon its } \\
\text { foundations. The photograph shews the height of } \\
\text { these foundations and the size of the stones with } \\
\text { which they were built; it also shews that the height } \\
\text { of the present building was originally at least three } \\
\text { stories. } \\
\text { The chambers are very numerous, but are small; } \\
\text { they are invariably arched or vaulted, the spaces } \\
\text { between the spurs of the arches were filled up with } \\
\text { crude bricks, and the floors were then levelled. No } \\
\text { stones were used above the foundations, and there } \\
\text { are no traces of beams or joists; in fact, owing to } \\
\text { the vaulted construction of the chambers, these } \\
\text { would have been quite unnecessary. } \\
\text { The building was erected on the northern angle of } \\
\text { the foundations, but although we traced them } \\
\text { carefully, we could not find any sculpture or } \\
\text { inscription. } \\
\text { J.D. }\end{array}$ \\
\hline NOTES & $\begin{array}{l}\text { Image from AMC, Photographic Views Taken in } \\
\text { Nubia. }\end{array}$ \\
\hline
\end{tabular}




\begin{tabular}{|c|c|}
\hline IMAGE & \\
\hline TITLE & Desert Scene [Desert Scene in Nubia.] \\
\hline MEDIUM & Albumen print from waxed paper negative \\
\hline CONCORDANCE & $\begin{array}{l}\text { AMC, Photographic Views in Egypt \& Nubia } \\
19.6 \text { x } 25.7 \mathrm{~cm} \\
\text { AMC, Photographic Views Taken in Egypt } \\
21.5 \times 27 \mathrm{~cm} \\
\text { AMC, Photographic Views Taken in Nubia } \\
21.4 \times 26.3 \mathrm{~cm} \\
\text { British Library } \\
21.2 \times 27.1 \mathrm{~cm} \\
\text { Wilbour Library of Egyptology } \\
21.8 \times 27 \mathrm{~cm}\end{array}$ \\
\hline TEXT & $\begin{array}{l}\text { DESERT SCENE IN NUBIA. } \\
\text { ABOVE the first cataract the scenery on the Nile } \\
\text { suddenly and entirely changes. The cultivated plain } \\
\text { with its villages, mosques and palm trees, has } \\
\text { disappeared, and given place to the barren rocks } \\
\text { and yellow sand of the desert; cultivation is } \\
\text { confined to a few feet on the river's edge, and even } \\
\text { this narrow fringe is frequently interrupted for } \\
\text { miles by the intrusion of the granite rocks. The } \\
\text { river flows through a rocky gorge, is narrower, } \\
\text { more rapid, and seems to be abandoned; since } \\
\text { leaving Philæ, not a sail has been seen, and the } \\
\text { geese, ducks, pelicans, spoonbills, and other water } \\
\text { fowl, with which the lower Nile was covered, have } \\
\text { disappeared. } \\
\text { The inhabitants are very scanty, and more scantily } \\
\text { clad; they consist principally of women and }\end{array}$ \\
\hline
\end{tabular}




\begin{tabular}{|l|l|}
\hline & $\begin{array}{l}\text { children, the men being engaged, for the most part, } \\
\text { as boatmen on the Lower Nile. }\end{array}$ \\
$\begin{array}{l}\text { It is a matter of wonder how even so scanty a } \\
\text { population manages to subsist on so narrow a strip } \\
\text { of land. From the left bank of the Nile, the desert, } \\
\text { under the name of the Sahara, stretches without } \\
\text { interruption, for } 2000 \text { miles towards the west coast } \\
\text { of Africa, and from the right bank, under the name } \\
\text { of the Arabian desert, it stretches to the Red Sea. } \\
\text { Over these spaces, the desert is not an } \\
\text { uninterrupted plain of sand, but, as seen in the } \\
\text { view is composed of rocky hills, of huge detached } \\
\text { masses of rock, of boulders, of pebbles and of } \\
\text { sand. It may be viewed as, and doubtless is the bed } \\
\text { of an ancient ocean, destitute of every principle of } \\
\text { vegetable life, excepting where the Nile, like a } \\
\text { silver cord, flows through the rocky channel which } \\
\text { it has made, and gives life and fertility only as far } \\
\text { as its waters reach. } \\
\text { Nothing can be conceived more sterile, more } \\
\text { desolate, more solitary and sunburnt, than the } \\
\text { desert, and nothing more death-like than its } \\
\text { stillness. }\end{array}$ \\
\hline NOTES \\
$\begin{array}{l}\text { J.D. } \\
\text { Nubia. }\end{array}$ \\
$\begin{array}{l}\text { Image from AMC, Photographic Views Taken in } \\
\text { Nubs }\end{array}$ \\
\hline
\end{tabular}

\begin{tabular}{|l|l|}
\hline IMAGE & \\
& \\
& \\
& \\
\hline TITLE & \\
\hline MEDIUM & Ibreem [Ibreem] \\
\hline CONCORDANCE & Albumen print from waxed paper negative \\
\hline & AMC, Photographic Views in Egypt \& Nubia \\
& $21.2 . x$ 26.8 cm \\
\hline
\end{tabular}




\begin{tabular}{|c|c|}
\hline & $\begin{array}{l}\text { AMC, Photographic Views Taken in Nubia } \\
20.8 \times 27.5 \mathrm{~cm} \\
\text { British Library } \\
21.2 \times 27.1 \mathrm{~cm} \\
\text { Université Laval } \\
20.6 \times 26.9 \mathrm{~cm} \\
\text { Wilbour Library of Egyptology } \\
21.8 \times 26.7 \mathrm{~cm}\end{array}$ \\
\hline TEXT & $\begin{array}{l}\text { IBREEM } \\
\text { IS a rugged rocky hill about } 800 \text { feet high, which } \\
\text { encroaches upon and literally overhangs the river. } \\
\text { Its base on all sides is honeycombed with tombs; } \\
\text { the greater number, however, have been defaced or } \\
\text { destroyed; but on the river side, where the face of } \\
\text { the hill is perpendicular, and where the tombs are } \\
\text { only accessible by means of ropes or of a long } \\
\text { ladder, they are still in good preservation, and bear } \\
\text { the dates and names of the Pharoahs who reined } \\
\text { from } 1600 \text { to } 1450 \text { B. C. }\end{array}$ \\
\hline & $\begin{array}{l}\text { The summit of the hill can only be reached from } \\
\text { the Desert side by a very narrow and precipitous } \\
\text { footpath, which leads through a rocky gorge, and } \\
\text { then zigzags past ancient tombs and among fallen } \\
\text { and detached masses of stone. } \\
\text { The top of the hill has been regularly laid out as a } \\
\text { town, the pavements of the streets and lanes, and } \\
\text { the remains of the houses are still very perfect, and } \\
\text { seem as if they could easily be restored. } \\
\text { There is also a Christian church in tolerable } \\
\text { preservation, the basilica of which, is } 60 \text { feet by } \\
36 \text {. This town has evidently been a place of } \\
\text { considerable importance, even in the older periods, } \\
\text { some of the blocks of stone built into the walls of } \\
\text { the church of the private houses bear the names } \\
\text { and titles of an Ethiopian monarch, who reigned in } \\
\text { Nubia during the } 18^{\text {th }} \text { Egyptian dynasty, and who } \\
\text { erected Temples on this platform ; these blocks had } \\
\text { been used by later Egyptian and Ptolemaic } \\
\text { monarchs, in the erection of Temples, and by the } \\
\text { Romans in building a castle and in surrounding the } \\
\text { whole top of the hill by a massive wall. }\end{array}$ \\
\hline
\end{tabular}




\begin{tabular}{|l|l|}
\hline & J.D. \\
\hline NOTES & $\begin{array}{l}\text { Image from AMC, Photographic Views Taken in } \\
\text { Nubia. }\end{array}$ \\
\hline
\end{tabular}

\begin{tabular}{|c|c|}
\hline IMAGE & \\
\hline TITLE & Ibreem- Roman Castle [Roman Castle of Ibreem.] \\
\hline MEDIUM & Albumen print from waxed paper negative \\
\hline CONCORDANCE & $\begin{array}{l}\text { AMC, Photographic Views in Egypt \& Nubia } \\
19.2 \text { x } 25.4 \mathrm{~cm} \\
\text { AMC, Photographic Views Taken in Egypt } \\
21.4 \text { x } 26.5 \mathrm{~cm} \\
\text { AMC, Photographic Views Taken in Nubia } \\
21.9 \times 27.3 \mathrm{~cm} \\
\text { British Library } \\
21.4 \text { x } 26.8 \mathrm{~cm} \\
\text { Wilbour Library of Egyptology } \\
21.8 \times 26.7 \mathrm{~cm}\end{array}$ \\
\hline TEXT & $\begin{array}{l}\text { ROMAN CASTLE OF IBREEM } \\
\text { AS well as the walls which surround the Town } \\
\text { have suffered very little by the ravages of time. } \\
\text { They have been very substantially built with huge } \\
\text { blocks of sandstone, many of which shew the } \\
\text { tracery and inscriptions, sculptured upon them by } \\
\text { the old Pharaohs. } \\
\text { When the Roman dominion expired in Egypt and } \\
\text { Nubia, the early Christians took possession of this } \\
\text { place; they left the Castle and walls entire, but } \\
\text { destroyed the Temples and Monuments, using the } \\
\text { materials and the sculptures stones in the buildings }\end{array}$ \\
\hline
\end{tabular}




\begin{tabular}{|c|c|}
\hline & $\begin{array}{l}\text { of their church and private dwellings; } \\
\text { consequently, the walls and pavements consist of } \\
\text { stones of different kinds - red and black granite, } \\
\text { limestone and sandstone. Under our feet and } \\
\text { around us, were the remains and memorials of } \\
\text { those who had ruled Egypt and Nubia for more } \\
\text { than forty centuries. } \\
\text { The Ethiop - the Egyptian - the Persian - the } \\
\text { Grecian - the Roman - the Christian, had in their } \\
\text { turns, strutted on this stage, and disappeared, The } \\
\text { Mahometan now has possession and exercises a } \\
\text { despotic rule; but, from the signs of the times, this } \\
\text { rule does not promise a long continuance. } \\
\text { The view from the Castle is very extensive, but } \\
\text { offers nothing but what is commonly seen above } \\
\text { the Cataract; the dreary, sun-burnt and } \\
\text { interminable Desert on every side, with no sign of } \\
\text { life excepting where the Nile flows through its } \\
\text { rocky bed, and supports a scanty vegetation } \\
\text { wherever the rocks and stones have permitted a } \\
\text { slight deposit of Nile mud. } \\
\text { J.D. }\end{array}$ \\
\hline NOTES & $\begin{array}{l}\text { Image from AMC, Photographic Views Taken in } \\
\text { Nubia. The image's orientation is the same in } \\
\text { AMC, Photographic Views Taken in Nubia, AMC, } \\
\text { Photographic Views in Egypt \& Nubia and the } \\
\text { Wilbour Library of Egyptology, but is laterally } \\
\text { reversed in the AMC, Photographic Views Taken } \\
\text { in Egypt album. }\end{array}$ \\
\hline
\end{tabular}

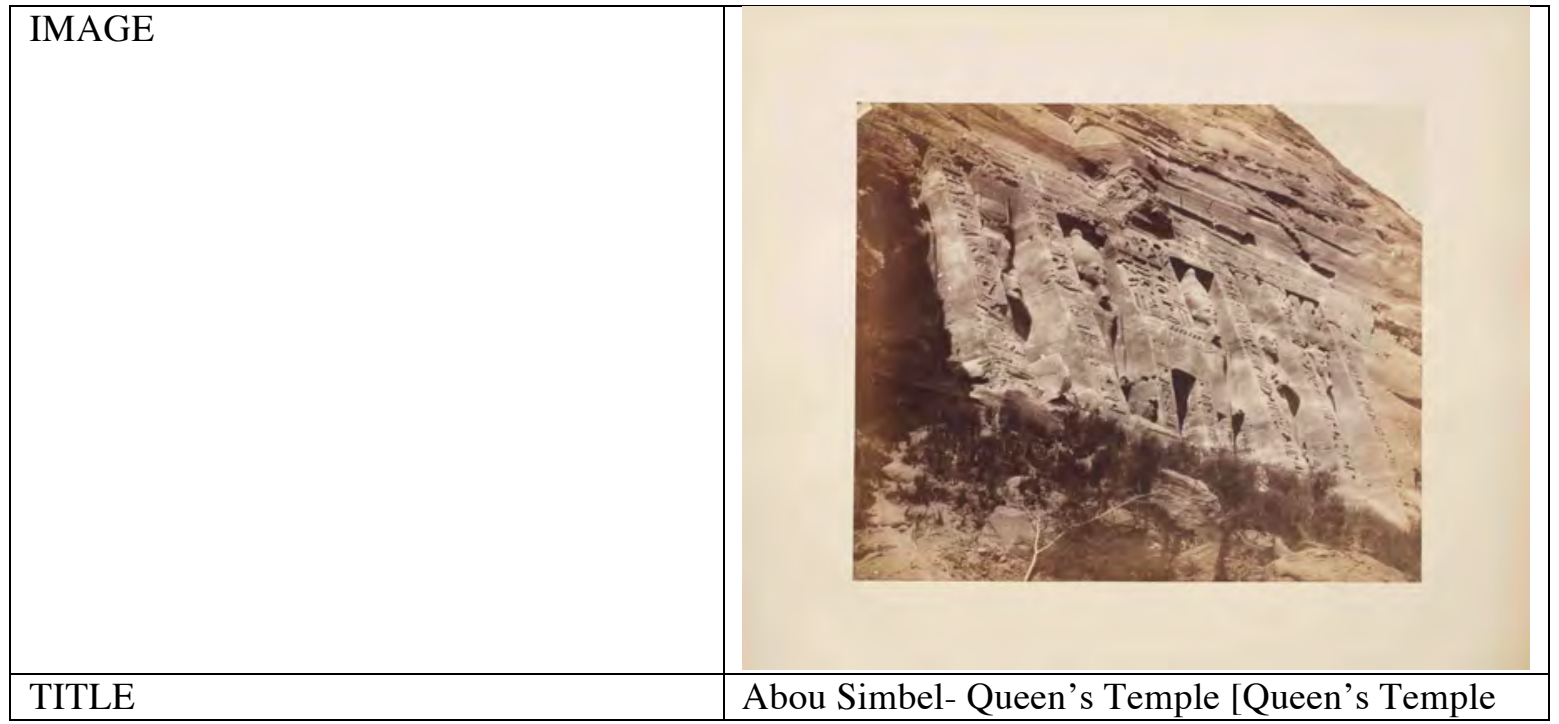




\begin{tabular}{|c|c|}
\hline & at Abou Simbel] \\
\hline MEDIUM & Albumen print from waxed paper negative \\
\hline CONCORDANCE & $\begin{array}{l}\text { AMC, Photographic Views in Egypt \& Nubia } \\
22 \times 27.6 \mathrm{~cm} \\
\text { AMC, Photographic Views Taken in Nubia } \\
24 \times 28.5 \mathrm{~cm} \\
\text { British Library } \\
23.9 \times 28.1 \mathrm{~cm} \\
\text { Université Laval } \\
21.8 \times 27.6 \mathrm{~cm} \\
\text { Wilbour Library of Egyptology } \\
21.7 \times 27 \mathrm{~cm}\end{array}$ \\
\hline TEXT & $\begin{array}{l}\text { QUEEN'S TEMPLE AT ABOU SIMBEL } \\
\text { IS situated a little to the North of the larger one, } \\
\text { and is similarly excavated out of the same Hill. } \\
\text { The inscriptions state, that it was commenced and } \\
\text { finished by Nofri Ari, the Queen of Rameses, and } \\
\text { dedicated by her to Athor, and some other deities. } \\
\text { As the sculptures and inscirptions on the larger } \\
\text { Temple commemorate the acts and conquests of } \\
\text { Rameses, on this, they are exclusively devoted to } \\
\text { the representations of the acts and offerings of his } \\
\text { Queen, and are entirely of a religious character. } \\
\text { As is seen in the photograph, the façade of this } \\
\text { Temple is cut so as to appear to be supported by } \\
\text { several natural buttresses which are covered with } \\
\text { hieroglyphics; between the buttresses six colossal } \\
\text { figures are sculptured and stand out in high relief. } \\
\text { The entrance, which is in one of the buttresses, } \\
\text { leads into the grand Hall; this is divided by two } \\
\text { rows of pillars, cut out of the solid rock, each pillar } \\
\text { having a colossal figure sculptured in high relief } \\
\text { upon its face. } \\
\text { The whole depth of the Temple from the entrance } \\
\text { is only } 100 \text { feet. The walls and pillars are } \\
\text { exquisitely carved and painted with the } \\
\text { representations of the acts and offerings of the } \\
\text { Queen to the deities, but, as in the larger Temple, } \\
\text { the King and the gods are sculptured of colossal } \\
\text { size, in this, they are only of life size. }\end{array}$ \\
\hline
\end{tabular}




\begin{tabular}{|l|l|}
\hline & $\begin{array}{l}\text { The heat, within both of these rock Temples, is } \\
\text { very great; there is no ventilation excepting } \\
\text { through the outer doorways, and these are nearly } \\
\text { blocked up by drifted sand, and only allow an } \\
\text { entrance by stooping. The air, however, though } \\
\text { heated and oppressive, does not feel impure. One } \\
\text { evening, the apparatus for a Turkish bath was } \\
\text { extemporized in the smaller Temple; one of the } \\
\text { Dahabieh's hatches was fitted up as a stage; a } \\
\text { couch with a Persian carpet and coverlids were } \\
\text { spread on the warm sand, and Mahmoud, the cook, } \\
\text { and one of the sailors, both professors of the bath } \\
\text { and shampooing, acted as operators. A fire was } \\
\text { kindled, the Hall and pillars were brilliantly } \\
\text { illuminated, and shewed Nofri Ariand her gods and } \\
\text { goddesses looking down on the unusual spectacle } \\
\text { with the same expression of solemn grandeur } \\
\text { which had been impressed on their countenances } \\
\text { 33 centuries before. }\end{array}$ \\
\begin{tabular}{ll} 
J.D. \\
\hline NOTES
\end{tabular} \\
\hline $\begin{array}{l}\text { Image from AMC, Photographic Views Taken in } \\
\text { Nubia. }\end{array}$ \\
\hline
\end{tabular}

\begin{tabular}{|l|l|}
\hline IMAGE & \\
& \\
& \\
\hline TITLE & \\
\hline CONEDIUM & Abou Simbel- King's Temple [Abou Simbel] \\
\hline Albumen print from waxed paper negative \\
\hline $\begin{array}{l}\text { AMC, Photographic Views in Egypt \& Nubia } \\
20.5 \times 26 \mathrm{~cm}\end{array}$ \\
\\
$\begin{array}{l}\text { AMC, Photographic Views Taken in Egypt } \\
20.5 \mathrm{x} 26 \mathrm{~cm}\end{array}$ \\
$\begin{array}{l}\text { AMC, Photographic Views Taken in Nubia } \\
21 \mathrm{x} 25.6 \mathrm{~cm}\end{array}$ \\
\hline
\end{tabular}




\begin{tabular}{|c|c|}
\hline & $\begin{array}{l}\text { British Library } \\
21.4 \times 27.6 \mathrm{~cm} \\
\text { Wilbour Library of Egyptology } \\
21.7 \times 27 \mathrm{~cm}\end{array}$ \\
\hline TEXT & $\begin{array}{l}\text { ABOU SIMBEL } \\
\text { MAY justly be considered as the king of the Rock } \\
\text { Temples of Egypt and Nubia. The sandstone hill } \\
\text { rises perpendicularly from the river. Its face has } \\
\text { been levelled, and four colossal sitting figures of } \\
\text { Rameses II have been cut out of it. } \\
\text { No description, and no measurements can give any } \\
\text { correct idea of the magnificence, the symmetry, } \\
\text { and the beauty of these statues; for, although } \\
\text { nearly seventy feet in height, their proportion are } \\
\text { so just, and their artistic finish so admirable, that } \\
\text { only after repeated visits can their grandeur, their } \\
\text { vastness and beauties begin to be fully realized. } \\
\text { The statues themselves, as well as the whole of the } \\
\text { exterior face of the hill are deeply sculptured with } \\
\text { representation of the gods, and with hieroglyphical } \\
\text { inscriptions of a size and depth in proportion to the } \\
\text { figures. } \\
\text { I visited every known Temple and monument in } \\
\text { Egypt and Nubia, and certainly the first view of no } \\
\text { one of them (not even excepting the great } \\
\text { Pyramid,) produced such a sensation of awe, as the } \\
\text { exterior face of the greater Rock Temple of Abou } \\
\text { Simbel. } \\
\text { The inside fully corresponds to the outer face; a } \\
\text { be formed from the dimensions of the pillars which } \\
\text { are eight feet square, and from the fact, that each } \\
\text { figure which stands out in bold relief, is thirty feet } \\
\text { inscriptions, leads to a hall supported by eight } \\
\text { pillars; on each pillar there stands out in high relief } \\
\text { a figure of Rameses, with the insignia of different } \\
\text { gods. The pillars, and the whole extent of the walls } \\
\text { are deeply sculptured with representations of his } \\
\text { battles, sieges, and exploits. The spirit and } \\
\text { execution of these scenes are admirable, and the } \\
\text { incidents can easily be understood without the aid } \\
\text { of the hieroglyphical inscriptions. } \\
\end{array}$ \\
\hline
\end{tabular}




\begin{tabular}{|c|c|}
\hline & $\begin{array}{l}\text { high, without its pedestal. } \\
\text { This Hall leads to another, and through this is the } \\
\text { entrance to the sanctuary which is } 200 \text { feet from } \\
\text { the outer doorway. On either side are seven large } \\
\text { chambers, all elaborately sculptured and painted. } \\
\text { The inscriptions state that the idea and plan of this } \\
\text { Temple originated with Rameses himself, for the } \\
\text { purpose of commemorating his victories and } \\
\text { conquests; and that the whole of the works were } \\
\text { executed solely by his captives. The greatness and } \\
\text { the cruelty of its accomplishment can only be } \\
\text { equalled by the vastness of conception and the skill } \\
\text { and resources of that wonderful monarch, who, } 33 \\
\text { centuries ago, cut out of a mountain so magnificent } \\
\text { a monument of his power, might and egotism. The } \\
\text { amount of time and labor expended on this gigantic } \\
\text { work can hardly be conceived, particularly as the } \\
\text { difficulties were increased by the fact, that, then, as } \\
\text { now, the country was entirely destitute of } \\
\text { vegetation, and presented on all sides, nothing but } \\
\text { the everlasting and dreary desert. } \\
\text { W.D. } \\
\text { We spent two days at Abou Simbel and took paper } \\
\text { impressions of several of the most interesting } \\
\text { subjects on the walls, all of which had reference to } \\
\text { the acts of Rameses. } \\
\text { Jathe }\end{array}$ \\
\hline NOTES & $\begin{array}{l}\text { Image from AMC, Photographic Views Taken in } \\
\text { Nubia. The image's orientation is the same in } \\
\text { AMC, Photographic Views Taken in Nubia, AMC, } \\
\text { Photographic Views in Egypt \& Nubia, the } \\
\text { Wilbour Library of Egyptology, but is laterally } \\
\text { reversed in AMC, Photographic Views Taken in } \\
\text { Egypt. }\end{array}$ \\
\hline
\end{tabular}




\begin{tabular}{|c|c|}
\hline IMAGE & \\
\hline TITLE & $\begin{array}{l}\text { Abou Simbel- Colossus [Abou Simbel. (Colossal } \\
\text { Statue.)] }\end{array}$ \\
\hline MEDIUM & Albumen print from waxed paper negative \\
\hline CONCORDANCE & $\begin{array}{l}\text { AMC, Photographic Views Taken in Nubia } \\
23.8 \times 29.3 \mathrm{~cm} \\
\text { British Library } \\
22 \times 29.4 \mathrm{~cm} \\
\text { Université Laval } \\
21.4 \text { x } 27.4 \mathrm{~cm} \\
\text { Wilbour Library of Egyptology } \\
20 \times 27 \mathrm{~cm}\end{array}$ \\
\hline TEXT & $\begin{array}{l}\text { ABOU SIMBEL. } \\
\text { (COLOSSAL STATUE.) } \\
\text { THE colossal Statues of Rameses II., which } \\
\text { ornament the Façade of the Rock-Temple of Abou } \\
\text { Simbel, are one of the wonders of the world, and } \\
\text { are certainly among the most marvelous } \\
\text { productions of the most marvelous people of } \\
\text { antiquity. } \\
\text { They are four in number, -- seated on thrones and } \\
\text { raised on high pedestals. Judging from the length } \\
\text { of such parts of the body as are exposed, } \\
\text { Wilkinson has calculated their total height at } 66 \mathrm{ft} . \\
\text { He gives the following dimensions of different } \\
\text { parts of the body: the ear, } 3 \mathrm{ft} .5 \text { in.; forefinger (i.e. } \\
\text { to the fork of the middle finger), } 3 \mathrm{ft} . ; \text { from the } \\
\text { inner side of the elbow-joint to the end of the } \\
\text { middle finger, } 15 \mathrm{ft} \text {. He likewise supposes the total } \\
\text { height of the Façade to be between } 90 \text { and } 100 \mathrm{ft} \text {. }\end{array}$ \\
\hline
\end{tabular}




\begin{tabular}{|c|c|}
\hline & $\begin{array}{l}\text { The legs and arms are square-set, the hands and } \\
\text { feet rest quite flat upon the knees and pedestal, and } \\
\text { the attitude possesses all the faults which adhere to } \\
\text { Egyptian sculpture. It would be absurd to offer a } \\
\text { defence of the palpable defects in their art. We can } \\
\text { only regret that religious prejudice and } \\
\text { conservativism should have prevented sculpture } \\
\text { and painting keeping pace with the advancement of } \\
\text { the social Arts in Egypt. Yet the remarks which } \\
\text { Fergusson makes in explanation of them, are just. } \\
\text { He accounts for them on the plea, that sculpture } \\
\text { was subordinate to architecture, and was not } \\
\text { pursued as an independent art; and that therefore } \\
\text { the Statues which adorned the Temples, were an } \\
\text { intrinsic part of the architectural plan of the } \\
\text { building, and in this respect resemble the awkward } \\
\text { effigies which fill the niches of a Gothic cathedral, } \\
\text { but are yet not offensive, because in keeping with } \\
\text { the whole. He then adds-speaking of the granite } \\
\text { Colossus of Rameses, in the outer court of the } \\
\text { Rameseum, and the remarks are applicable with } \\
\text { double force to these: "To my mind this monolithic } \\
\text { Colossus, } 60 \text { ft. high, seated in calm majesty } \\
\text { among architectural objects of a corresponding size } \\
\text { and design, and of which he forms a part, is a more } \\
\text { sublime conception than has yet been executed in } \\
\text { any part of the earth, as the memorial of a man } \\
\text { who was great in life, and who wished to convey to } \\
\text { posterity a just appreciation of his powers. It is not } \\
\text { the mere Colossus, a man beautiful in form and } \\
\text { limb-but a king, or, ascending to the Egyptian } \\
\text { conception, a demi-god. Look at it as we will, no } \\
\text { portrait statue has ever been conceived so sublime } \\
\text { and god-like, nothing ever executed so } \\
\text { mechanically great." } \\
\text { J.D., JR. }\end{array}$ \\
\hline NOTES & $\begin{array}{l}\text { Image from AMC, Photographic Views Taken in } \\
\text { Nubia. }\end{array}$ \\
\hline
\end{tabular}




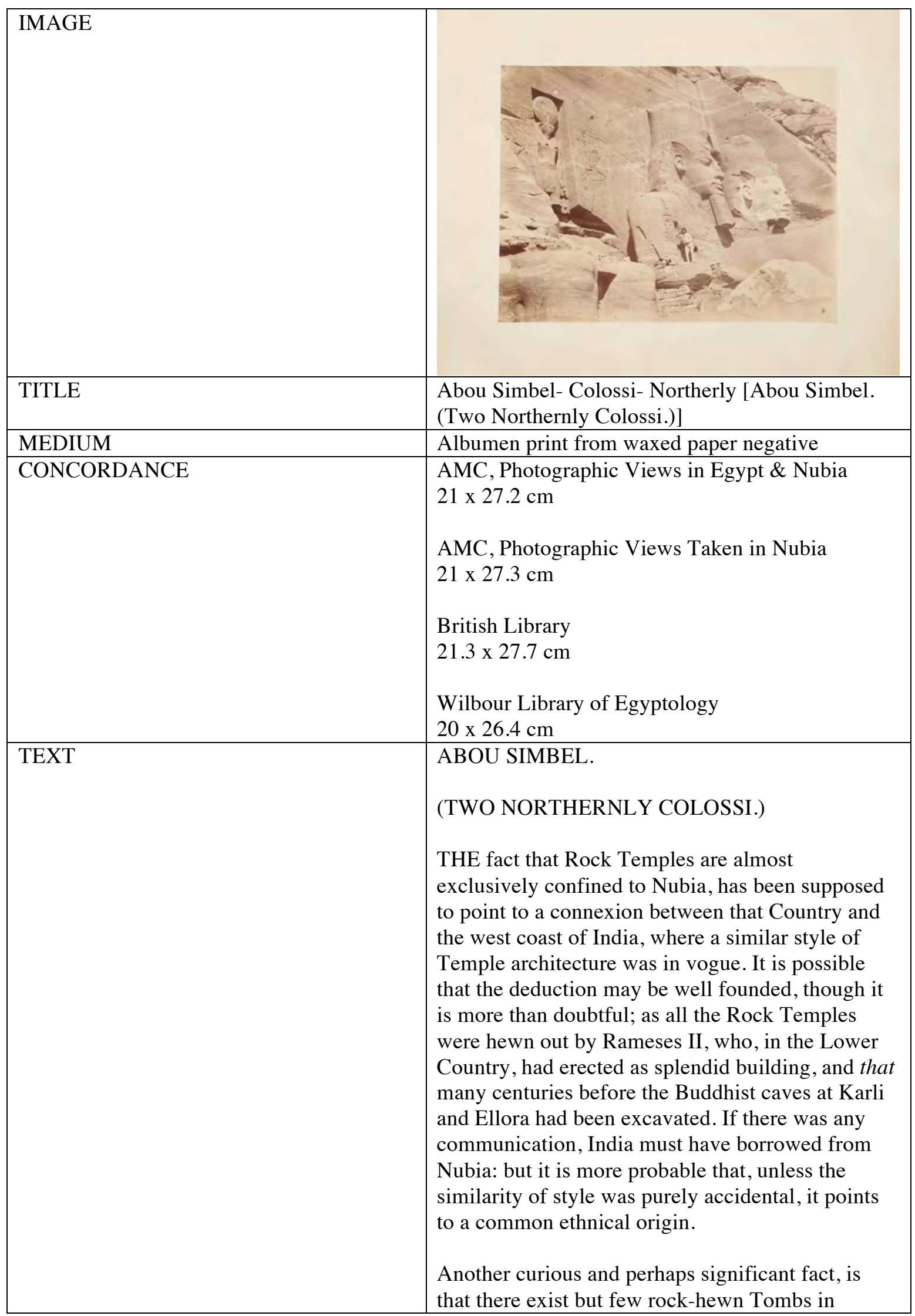




\begin{tabular}{|l|l|}
\hline & $\begin{array}{l}\text { Nubia, and those few principally on the east bank. } \\
\text { Further investigation may clear up those points ; } \\
\text { and the many hypothesis founded on them share } \\
\text { the same fate, which has befallen the thousand } \\
\text { groundless and ubsurd theories which were } \\
\text { confidently propounded before the discovery of } \\
\text { reading the hieroglyphical writing was made. It } \\
\text { was then supposed that civilisation descended the } \\
\text { Nile from Ethiopia, and that the Pyramids and } \\
\text { other remains of Moroe, now ascertained to be of } \\
\text { comparatively late date, were the most ancient } \\
\text { monuments of the world; and that the rock hewn } \\
\text { Temples of Nubia suggested the architecture of the } \\
\text { magnificent structures of Egypt. On the contrary, } \\
\text { the excavated temples are planned after the model } \\
\text { of the constructed; and what is more, the oldest } \\
\text { grottoes of the Old Empire possess architectural } \\
\text { parts, utterly useless in an excavation, and which } \\
\text { are therefore introduced only in imitation of } \\
\text { buildings then in existence. The grottoes of Beni } \\
\text { Hassan again excavated toward the close of the } \\
\text { Old Empire, indicate a fully developed } \\
\text { architectural style, as perfect as that of Greece and } \\
\text { Rome. Thus the origin of Egyptian architecture is } \\
\text { lost in the dim distance. It seems like everything in } \\
\text { that mysterious land to have had no beginning; but } \\
\text { in truth leads us back, in tracing its gradual rise } \\
\text { and progress, into a past far more remote than we } \\
\text { ever before could conceive of. }\end{array}$ \\
\hline J.D., JR. \\
$\begin{array}{l}\text { Image from AMC, Photographic Views Taken in } \\
\text { Nubia. }\end{array}$ \\
\hline
\end{tabular}




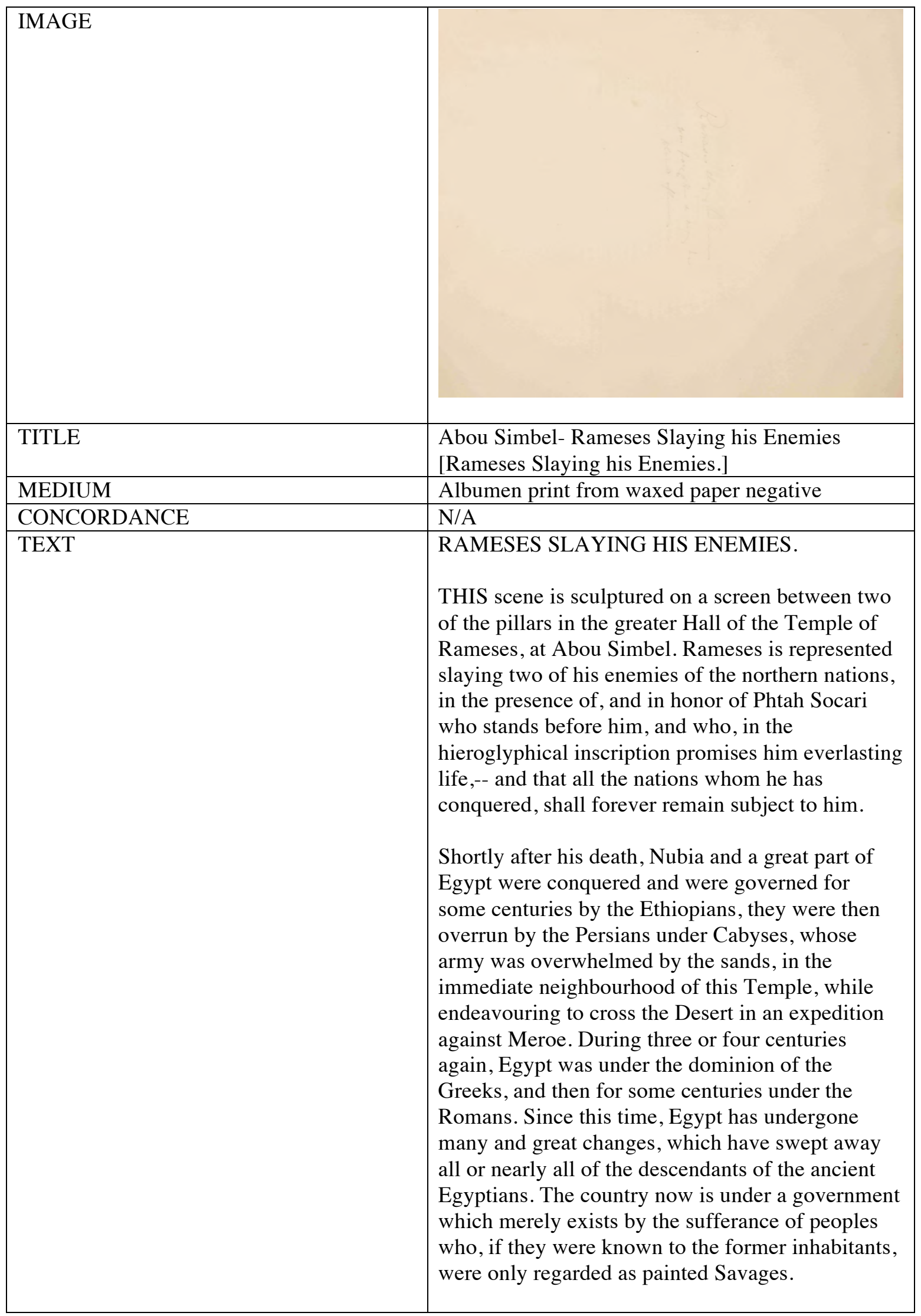




\begin{tabular}{|l|l|}
\hline & J.D. \\
\hline NOTES & $\begin{array}{l}\text { Image from AMC, Photographic Views Taken in } \\
\text { Nubia. No image found in AMC, Photographic }\end{array}$ \\
& $\begin{array}{l}\text { Views in Egypt \& Nubia, AMC, Photographic } \\
\text { Views Taken in Egypt, AMC, Photographic Views } \\
\text { Taken in Nubia, British Library, Université Laval, } \\
\text { or Wilbour Library of Egyptology. }\end{array}$ \\
\hline
\end{tabular}




\section{BIBLIOGRAPHY}

Badger, Gerry. "Early Photography in Egypt." Creative Camera (1979): 401-429.

Baedeker, Karl. Egypt. Handbook for Travellers. Leipzig: K. Baedeker, 1892.

Behdad, Ali. Photography's Orientalism: New Essays on Colonial Representation. Ed. Ali Behdad and Luke Gartlan. Los Angeles, CA: Getty Research Institute, 2013.

Belzoni, Giovanni Battista and Sarah Belzoni. Narrative of the operations and recent discoveries within the pyramids, temples, tombs, and excavations, in Egypt and Nubia; and of a journey to the coast of the Red Sea, in search of the ancient Berenice, and of another to the oasis of Jupiter Ammon. London: John Murray, 1820.

Blair, Louisa. "Corpses and Maniacs: The Loves of Dr. James Douglas." Canadian Family Physician 47 (2001): 339-41.

Clayton, Peter A. The Rediscovery of Ancient Egypt: Artists and Travelers in the 19th Century. London: Thames and Hudson, 1982.

Chevedden, Paul E. "Making Light of Everything: Early Photography of the Middle East and Current Photomania." Middle East Studies Association Bulletin 18 (December 1984): 151-174.

Chevedden, Paul E. The Photographic Heritage of the Middle East: An Exhibition of Early Photographs of Egypt, Palestine, Syria, Turkey, Greece, \& Iran, 1849-1893. Malibu: Undena Publications, 1981.

David, A. Rosalie. The Experience of Ancient Egypt. London: Routledge, 2000.

Douglas, James, and James Douglas Jr. Journals and Reminiscences of James Douglas, M.D. New York: Private Printing, 1910.

“Douglas, James, 1837-1918. Dr. James Douglas Collection, 1863-1935.” Arizona Historical Society. Web May 15, 2014.<http://www.azarchivesonline.org/xtf/view? docId=ead/ahssd/ms1031.xml $>$.

Douglas Jr., James, "The Belief of the Ancient Egyptians Respecting a Future State."

Transactions, Volumes 4-5: Literary and Historical Society of Quebec. Quebec: Hunter, Rose \& Co., 1865.

Douglas Jr., James, “On Two Mummies from Thebes, in Upper Egypt.” Transactions, Volumes 25: Literary and Historical Society of Quebec. Quebec: Hunter, Rose \& Co., 1864.

Douglas Jr., James, "On Recent Spectroscopic Observations of the Sun, and the Total Eclipse of the $7^{\text {th }}$ August 1869." Transactions, Volume 3: Literary and Historical Society of Quebec. Quebec: Hunter, Rose \& Co., 1870.

Frith, Francis. Egypt, Sinai, and Palestine, volume 1. London: William Mackenzie, 1862. 
Frith, Francis. Lower Egypt, Thebes, and the Pyramids, volume 1. London: William Mackenzie, 1862.

Frith, Francis. Upper Egypt and Ethiopia, volume 1. London: William Mackenzie, 1862.

Gordon, Sophie. Cairo to Constantinople: Francis Bedford's Photographs of the Middle East. London: Royal Collection Trust, 2013.

Gregory, Derek. "Emperors of the Gaze: Photographic Practices and Productions of Space in Egypt, 1839-1914." Picturing Place: Photography and the Geographical Imagination. Ed. Joan M. Schwartz and James R. Ryan. London: I.B. Tauris, 2003.

Gregory, Derek. "Scripting Egypt: Orientalism and the Cultures of Travel." Picturing Place: Photography and the Geographical Imagination. Ed. Joan M. Schwartz and James R. Ryan. London: I.B. Tauris, 2003.

Hannavy, John. Encyclopedia of Nineteenth Century Photography. London. Routledge, 2008.

Harris, David. Of Battle and Beauty: Felice Beato's Photographs of China. Santa Barbara, CA: Santa Barbara Museum of Art, 1999.

Howe, Kathleen Stewart. Excursions along the Nile: The Photographic Discovery of Ancient Egypt. Santa Barbara, CA: Santa Barbara Museum of Art, 1993.

Irby, Charles Leonard, and James Mangles. Travels in Egypt and Nubia, Syria, and the Holy Land; including a Journey round the Dead Sea, and through the Country East of the Jordan. London: John Murray, 1844.

Kalfatovic, Martin R. Nile Notes of a Howadji: A Bibliography of Travelers' Tales from Egypt, from the Earliest Time to 1918. Metuchen, NJ: Scarecrow, 1992.

Killingray, David, and Andrew Roberts. "An Outline History of Photography in Africa to Ca. 1940.” History in Africa 16 (1989): 197-208.

Lavédrine, Bertrand. Photographs of the Past: Process and Preservation. Los Angeles: Getty Conservation Institute, 2009.

Langton, H. H. James Douglas: A Memoir. Toronto: University of Toronto, 1940.

Leblond, Sylvio. "Douglas, James (1800-86)." Dictionary of Canadian Biography. University of Toronto, 1982. Web. 27 Sept. 2013.

<http://www.biographi.ca/en/bio/douglas_james_1800_86_11E.html>.

Leblond, Sylvio. “James Douglas M.D. (1800-1886).” Canadian Medical Assoc. 66.3 (1952): 283-87.

Lyons, Claire L. Antiquity \& Photography: Early Views of Ancient Mediterranean Sites. Los Angeles: J. Paul Getty Museum, 2005. 
Murray, John. A Handbook for Travellers in Lower and Upper Egypt; including Descriptions of the Course of the Nile through Egypt and Nubia, Alexandria, Cairo, the Pyramids, Thebes, the Suez Canal, the Peninsula of Mount Sinai, the Oases, the Faycom, $\& c$. London: John Murray, 1880.

Nickel, Douglas R. Francis Frith in Egypt and Palestine: A Victorian Photographer Abroad. Princeton, NJ: Princeton UP, 2004.

Norden, Frederik Ludvig. Travels in Egypt and Nubia. Vol. 2. London: L. Davis and C. Reymers, 1757.

Peck, William H., and Martha Mardirosian. Splendors of the Nile: Nineteenth-century Photographs of Egypt: Albert and Peggy De Salle Gallery of Photography, Detroit Institute of Arts, February 21st-May 7th, 1989. Detroit, MI: Institute, 1989.

Perez, Nissan N. Focus East: Early Photography in the Near East 1839-1885. New York: Abrams, 1988.

Reilly, James M. The Albumen and Salted Paper Book: The History and Practice of Photographic Printing 1840-1895. Rochester, NY: Light Impressions Corp., 1980.

Sennett, Robert S. Photography and Photographers to 1900: An Annotated Bibliography. New York: Garland, 1985.

St, John James Augustus. Egypt and Nubia, Their Scenery and Their People: Being Incidents of History and Travel, from the Best and Most Recent Authorities, including J.L. Burckhardt and Lord Lindsay. London: Chapman and Hall, 1845.

The Mummy Who Would Be King. Directed by Gail Willumsen. 2005. NOVA Productions, January 3, 2006. VHS.

Wilkinson, Sir John Gardner. A Handbook for Travellers in Egypt: including descriptions of the course of the Nile to the Second Cataract, Alexandria, Cairo, the Pyramids, and Thebes, the overland transit to India, the peninsula of Mount Sinai, the Oases, \&c., London: John Murray, 1847.

Wilkinson, Sir John Gardner, A Popular Account of the Ancient Egyptians: 2, Volume 2, London: John Murray, 1854. 